UNIVERSIDADE DE SÃO PAULO

FACULDADE DE ECONOMIA, ADMINISTRAÇÃO E CONTABILIDADE DEPARTAMENTO DE CONTABILIDADE E ATUÁRIA

\title{
HARMONIZAÇÃO CONTÁBIL EM CINCO PAÍSES DA AMÉRICA DO SUL
} VOLUME 1

ANA MARÍA HINOJOSA AMENÁBAR

ORIENTADOR: PROF. DR. L. NELSON G. DE CARVALHO

SÃO PAULO - BRASIL 
Reitor da Universidade de São Paulo

Prof. Dr. Jacques Marcovitch

Diretor da Faculdade de Economia, Administração e Contabilidade Prof. Dr. Eliseu Martins

Chefe do Departamento de Contabilidade e Atuaria

Prof. Dr. Reinaldo Guerreiro 
UNIVERSIDADE DE SÃO PAULO

FACULDADE DE ECONOMIA, ADMINISTRAÇÃO E CONTABILIDADE DEPARTAMENTO DE CONTABILIDADE E ATUÁRIA

\title{
HARMONIZAÇÃO CONTÁBIL EM CINCO
}

\section{PAÍSES DA AMÉRICA DO SUL}

\author{
VOLUME 1
}

\begin{abstract}
ANA MARÍA HINOJOSA AMENÁBAR
ORIENTADOR: PROF. DR. L. NELSON G. DE CARVALHO

Dissertação apresentada à Faculdade de Economia, Administração e Contabilidade da Universidade de São Paulo para obtenção do título do Mestre em Controladoria e Contabilidade
\end{abstract}

SÃO PAULO - BRASIL 


\section{AGRADEÇO:}

A Deus por sua infinita bondade para comigo;

a meus Pais por seu amor, compreensão,

apoio e por todos os princípios que eles me

ensinaram e que guiam minha vida;

a meu irmão David pelo amor e apoio que

recebi dele;

a meus Professores Orientadores, Dr. Nelson

Carvalho e Dr. Nahor Plácido Lisboa

pela ajuda e por seus sábios conselhos;

a meus Professores pelo ensino, paciência e orientação que recebi deles;

a meus Colegas pela sua amizade e apoio. 


\section{RESUMO}

A harmonização contábil é uma preocupação mundial em um ambiente de desenvolvimento e de globalização de economias, existindo esforços para torná-la viável. Os blocos econômicos procuram encontrar soluções para as diferenças existentes entre as normas contábeis.

O presente trabalho é um estudo sobre a harmonização contábil em cinco Países da América do Sul e a necessidade de implementar dita harmonização.

Inicialmente são apresentados os antecedentes dos dois blocos econômicos da América do Sul, o Mercosul e a Comunidade Andina; em seguida, são estudadas as características de ambos os blocos e seus objetivos. Posteriormente são analisados os marcos conceituais contábeis e algumas das principais semelhanças e divergências de critérios na contabilidade de cinco países: Argentina, Brasil, Colômbia, Peru e Venezuela. Na última parte, são feitas as considerações finais do trabalho, destacando-se a importância de se conseguir a harmonização contábil. 


\section{ABSTRACT}

The harmonization of the accounting standards is a world preoccupation in a global economy. The preparers and users of the financial reports make efforts for achieving harmonization. Leaders of the accounting profession from most economic regions try to find solutions for the differences that exist among the accounting standards.

This work is a study about the harmonization of the accounting standards in five South American countries and the necessity of achieving this harmonization.

The origins of the two mega common markets from South America, namely Mercosul and The Andean Community are examined first, followed by an analysis of their characteristics and of their objectives. After that, this work continues with an analysis of the accounting framework and the major similarities and differences of standards in five countries: Argentina, Brazil, Colombia, Peru and Venezuela. Finally the conclusions are presented, emphasizing the importance of achieving the harmonization of the accounting standards. 


\section{SUMÁRI O DO VOLUME 1}

\section{AGRADECI MENTOS}

RESUMO

.ii

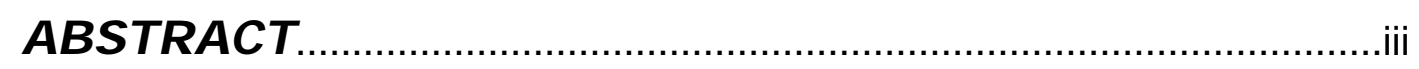

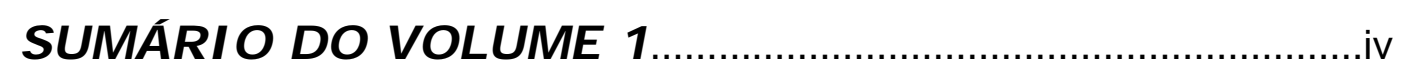

SUMÁRIO DO VOLUME 2 - ANEXOS ...................................ii

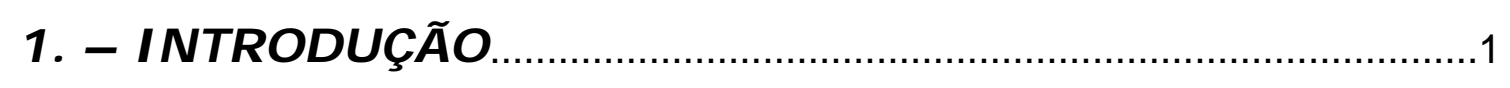

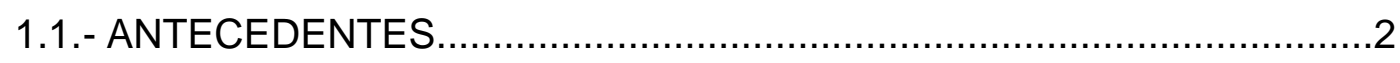

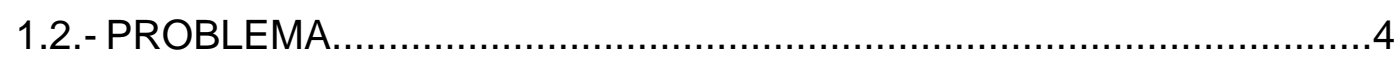

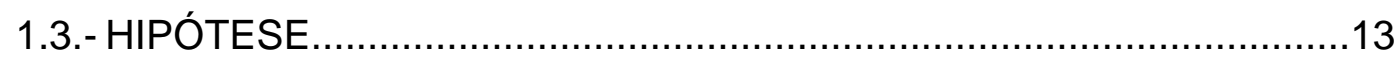

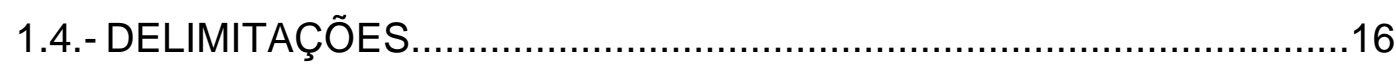

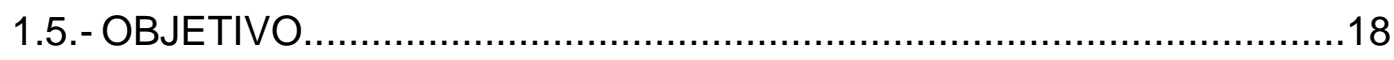

1.6. METODOLOGIA................................................................ 19

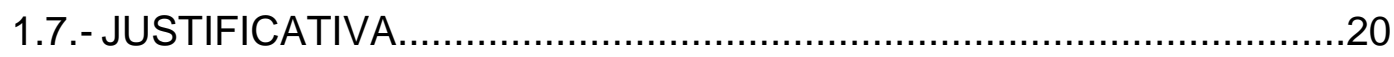

\section{2. - O PROCESSO DA I NTEGRAÇÃO NA AMÉRI CA DO}

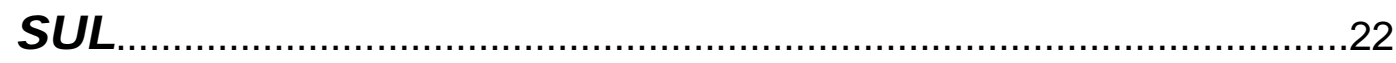

2.1.- ASPECTOS GERAIS DA COMUNIDADE ANDINA ........................22

2.1.1.- OBJETIVOS DA COMUNIDADE ANDINA ...............................40 
2.1.2.- ESTRUTURA INSTITUCIONAL DA COMUNIDADE ANDINA...........40

2.1.3.- INSTRUMENTOS ECONÔMICOS DA INTEGRAÇÃO ANDINA........42

2.2.- ASPECTOS GERAIS DO MERCOSUL.............................................42

2.2.1. - PAÍSES INTEGRANTES DO MERCOSUL....................................46

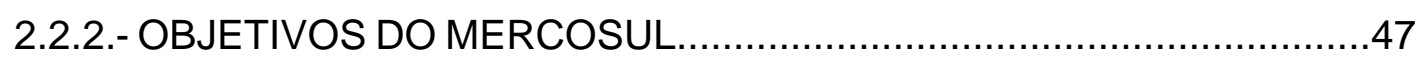

2.2.3. - ESTRUTURA INSTITUCIONAL DO MERCOSUL...........................48

2.3.- RELAÇÃO MERCOSUL E COMUNIDADE ANDINA............................49

2.3.1.- PRINCÍPIOS BÁSICOS DO ACORDO............................................50

2.3.2.- OBJETIVOS DO ACORDO...........................................................

2.3.3.- ESTABELECIMENTO DA ÁREA DE LIVRE COMÉRCIO.................52

3.- MARCO CONCEI TUAL DOS CI NCO PAÍ SES....................56

3.1.- QUADROS DOS MARCOS CONCEITUAIS DOS CINCO PAÍSES.....62

3.2.- CONCLUSÕES SOBRE O MARCO CONCEITUAL DOS CINCO

PAÍSES. 68

\section{4.- ALGUMAS DI FERENÇAS E SEMELHANÇAS NA}

CONTABI LI DADE

4.1.- DEMONSTRAÇÕES FINANCEIRAS...............................................

4.2.- DEMONSTRAÇÃO DA SITUAÇÃO PATRIMONIAL.............................91

4.2.1.- CONCLUSÕES SOBRE A DEMONSTRAÇÃO DA SITUAÇÃO

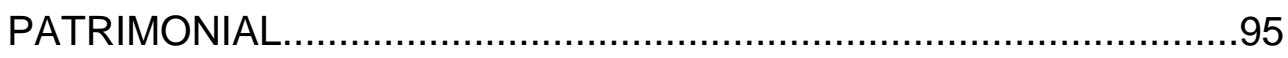


4.3.- DIFERENÇAS E SEMELHANÇAS PRINCIPAIS NA CONTABILIDADE. .96

4.3.1.- CONCLUSÕES SOBRE OS ESTOQUES. 96

4.3.2.- CONCLUSÕES SOBRE OS INVESTIMENTOS PERMANENTES...111

4.3.3.- CONCLUSÕES SOBRE O IMOBILIZADO 122

4.3.4.- CONCLUSÕES SOBRE O ARRENDAMENTO MERCANTIL............129

4.3.5.- CONCLUSÕES SOBRE O ATIVO DIFERIDO 134

4.3.6.- CONCLUSÕES SOBRE TÉCNICAS DE RECONHECIMENTO DA INFLAÇÃO

5.- CONSI DERAÇÕES FI NAIS. 159 REFERÊNCI AS BI BLI OGRÁFI CAS 162 


\section{SUMÁRIO DO VOLUME 2 - ANEXOS}

\section{1.- PRI NCÍ PIOS CONTÁBEIS NA AMÉRI CA DO}

SUL

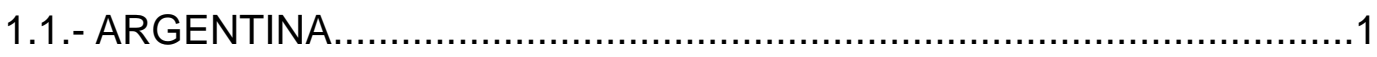

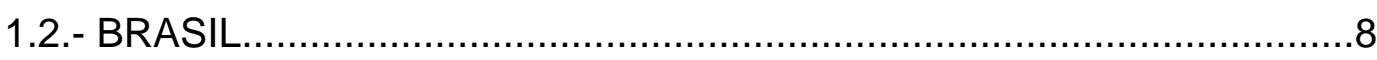

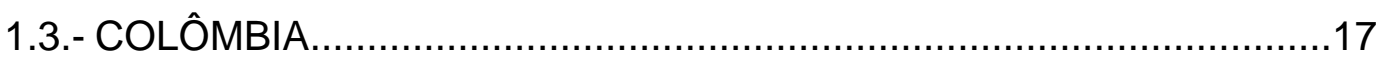

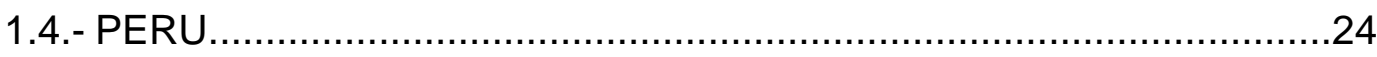

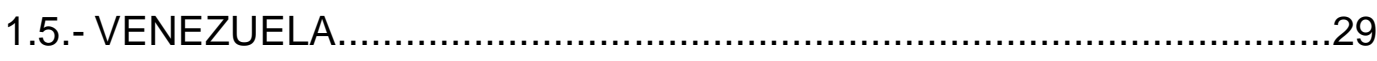

2.- ESTOQUES

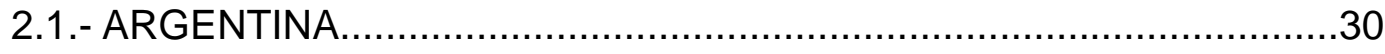

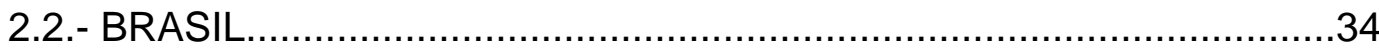

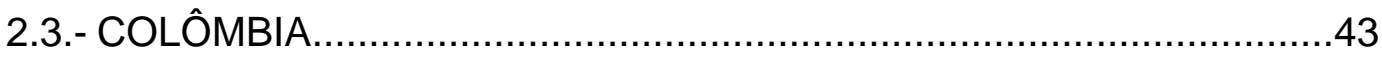

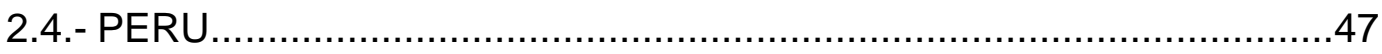

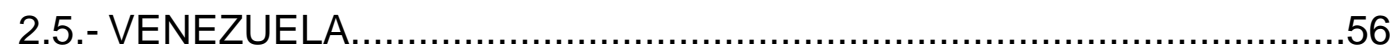

3.- I NVESTI MENTOS PERMANENTES ........................................58

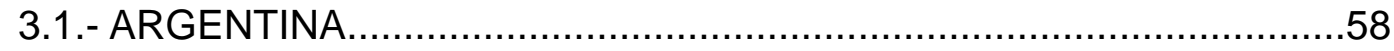

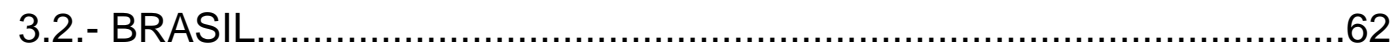

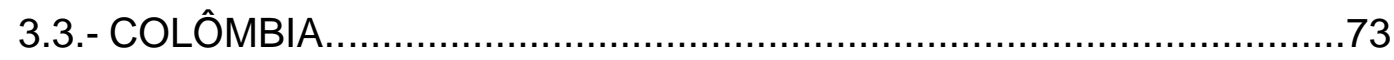

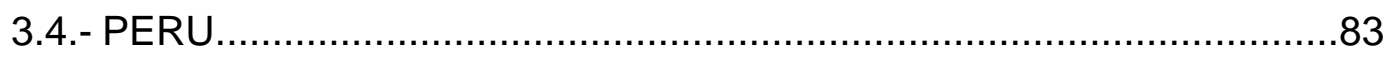

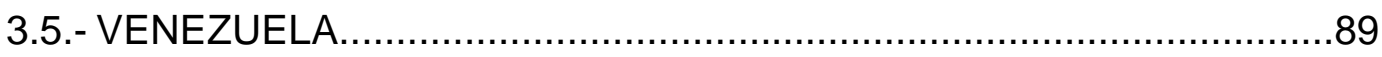


4.- ATI VO I MOBI LI ZADO

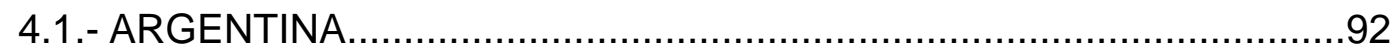

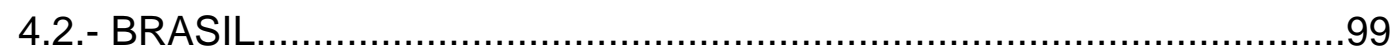

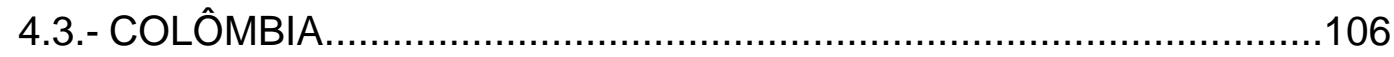

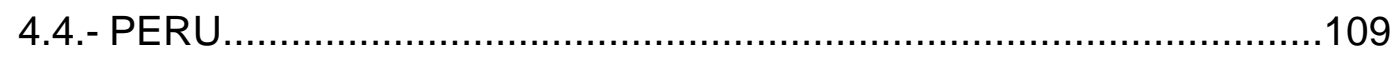

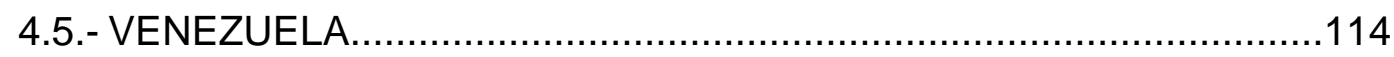

5.- ARRENDAMENTO MERCANTI L OU LEASI NG...............123

5.1.- NORMAS INTERNACIONAIS DO LEASING ...............................123

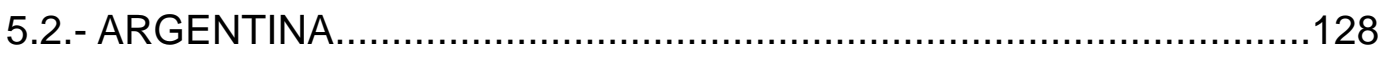

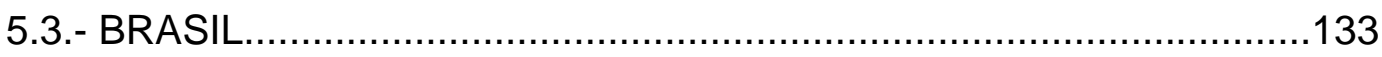

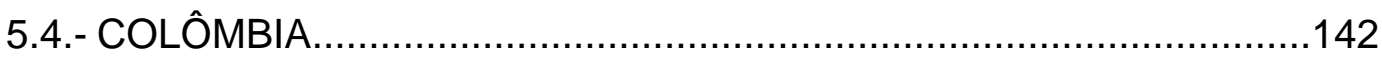

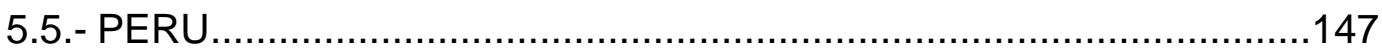

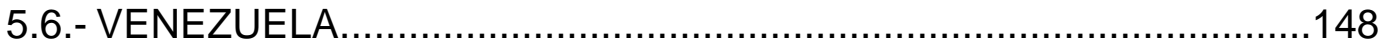

6.- ATI VO DI FERI DO

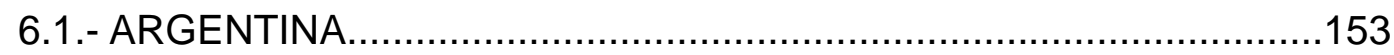

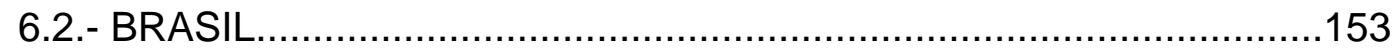

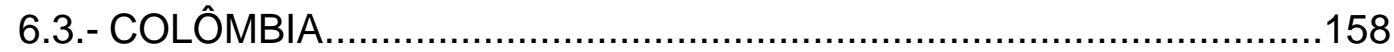

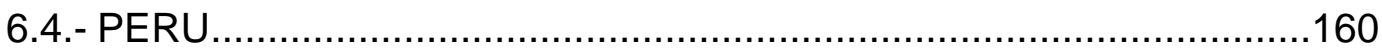

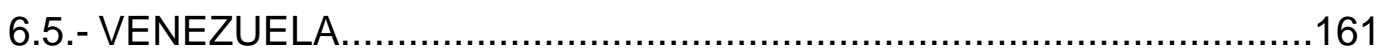


7.- TÉCNI CAS DE RECONHECI MENTO DA I NFLAÇÃO...166

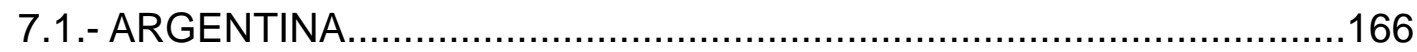

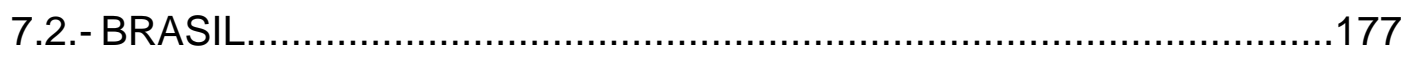

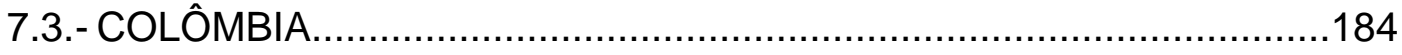

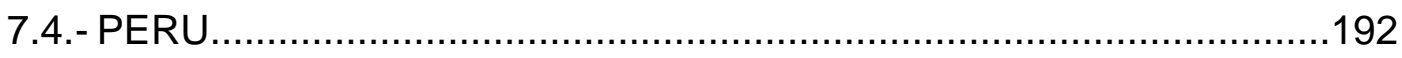

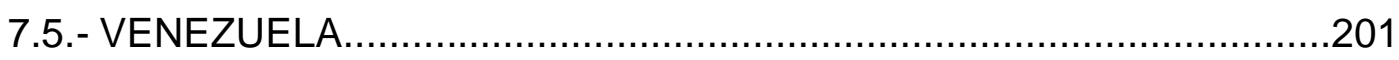

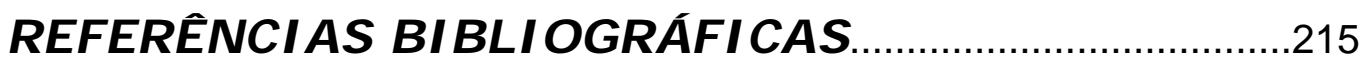




\section{1. - I NTRODUÇÃO}

No mundo de hoje, num ambiente de pleno desenvolvimento da globalização de economias e dos mercados de capitais, é possível compreender a importância da harmonização das normas contábeis.

Nos países da América do Sul, aparentemente, não existe ainda uma harmonização das normas contábeis. Devido à sua importância, os países da América do Sul deveriam concordar em uma série de atuações que conduzam paulatinamente a uma harmonização através de aproximações legislativas, da homologação de significados e de usos, e equivalência de medidas com o fim de se conseguir maior aproximação e integração entre si para melhorar o desempenho de suas empresas, se proteger economicamente e atuar como bloco econômico diante dos outros blocos do mundo.

A harmonização contábil na América Latina deve provavelmente ser realizada partindo de um esquema conceitual contábil comum ${ }^{1}$, mas que respeite as características e peculiaridades de cada país, e com uma aproximação e equilíbrio com as normas contábeis internacionais. 


\section{1.- ANTECEDENTES}

Na América do Sul, formaram-se dois blocos econômicos de países com o objetivo de obter a integração econômica.

O Pacto Andino ou Acordo de Cartagena, também conhecido como Grupo Andino, foi assinado em 26 de maio de 1969, na cidade de Bogotá, capital da República da Colômbia.

As bases orgânicas da estrutura jurídico-política desta moderna união econômica foram propostas na cidade colombiana de Cartagena.

Seis meses depois, em 24 de novembro de 1969, a Comissão, que é o organismo máximo, decidiu denominar o grupo "Acordo de Cartagena", em homenagem à cidade.

Inicialmente foi subscrito pelos representantes dos seguintes governos: Bolívia, Colômbia, Chile, Equador e Peru; a Venezuela uniu-se ao Acordo de Cartagena em 13 de fevereiro de 1973, mediante a Decisão ํo 70 da Comissão. O Chile retirou-se em 1976.

Devido às reformas institucionais adotadas em 1996 e implementadas a partir de 1997, o Grupo Andino converteu-se em uma Comunidade Andina - CAN, cujo objetivo imediato, quando estiver praticamente concluída a criação da zona de livre comércio, é construir um mercado comum onde exista a plena mobilidade

\footnotetext{
${ }^{1}$ NOTA: Esta expressão tem como equivalente, no Brasil, "Estrutura Conceitual”. A partir daqui, neste trabalho, usaremos a expressão "Marco Conceitual” com o mesmo significado.
} 
de fatores produtivos, e onde também possa existir a integração dos diversos setores e instituições que formam parte da sociedade civil das nações andinas.

Já o bloco econômico Mercosul é integrado por quatro países: Argentina, Brasil, Paraguai e Uruguai, tendo o compromisso para sua constituição sido firmado através do Tratado de Assunção, em 1991.

\begin{abstract}
"Os países do Mercosul deram um passo decisivo em seu processo de integração econômica no âmbito do Mercado Comum do Sul em 10 de janeiro de 1995, com a formação de uma zona de livre comércio e de uma união aduaneira parcial. A constituição de um mercado comum, prevista pelo Tratado de Assunção, teve que ser adiada em razão das dificuldades de se levar a cabo um projeto tão ambicioso envolvendo países com estruturas produtivas tão diferentes em um prazo tão exíguo, menos de quatro anos".2
\end{abstract}

Devido à importância do Mercosul, associaram-se a ele ${ }^{3}$ o Chile, em outubro de 1996 e a Bolívia, em janeiro de 1997. Tais países, no entanto, aderiram em uma forma menos exigente do que a plena integração; por essa razão, deixamos de comparar suas normas contábeis neste trabalho.

O Acordo Marco para a Criação de uma Região de Livre Comércio entre a Comunidade Andina e o Mercosul foi assinado em 16 de abril de 1998, em Buenos Aires, Argentina.

Segundo dados da Comunidade Andina, ${ }^{4}$ este acordo vai beneficiar a 300 milhões de habitantes, cujo Produto Interno Bruto é de 1,2 trilhões de dólares em 1999.

\footnotetext{
${ }^{2}$ Lima Régo, Elba. O Processo de Integração no Mercosul. Revista do BNDES. Rio de Janeiro, 1995. V.2. n. 3. P. 167.

${ }^{3}$ Da Rosa, Paulo Moreira. A Contabilidade no Mercosul. São Paulo, 1999. p.19.

${ }^{4}$ http://www.comunidadandina.org/
} 
Em agosto de 1999, Brasil e a Comunidade Andina assinaram um Acordo Complementar Econômico como um avanço para a criação da região de livre comércio. Com o mesmo objetivo, a Argentina e a Comunidade Andina assinaram um acordo similar em 29 de junho de 2000. Os outros países do Mercosul, Paraguai e Uruguai, estão se preparando para realizar acordos similares com a CAN.

Na reunião dos Presidentes da América do Sul, no ano 2000, foi marcado o mês de janeiro de 2002 como o prazo para o estabelecimento do Livre Comércio entre os dois Blocos.

\section{2.- PROBLEMA}

O Problema insere-se na seguinte pergunta:

Há harmonização contábil nos cinco países, escolhidos para este trabalho, da América do Sul?

Primeiro é necessário conhecer o significado do termo harmonização.

Segundo Raúl Grien: "Harmonização é sinônimo de integração".

A harmonização contábil é um processo através do qual vários países de comum acordo realizam mudanças nos seus sistemas e normas contábeis para torná-los compatíveis, partindo da identificação de uma teoria geral da 
contabilidade e um marco conceitual comum que fundamente suas normas contábeis, considerando a influência dessas normas na economia, e respeitando as características e peculiaridades de cada país dentro de um contexto de integração econômica. Deve existir, ademais, uma conciliação entre a harmonização das normas contábeis e as características de cada país.

Existem diversos pesquisadores que falam sobre harmonização.

Segundo John Blake e Oriol Amat: ${ }^{6}$

1) "Existem diferenças muito significativas em normas contábeis entre países diferentes.

2) Existe uma grande demanda pela harmonização na contabilidade internacional.

3) Existem razões muito fortes para a diversidade internacional de normas contábeis, e conseqüentemente obstáculos significativos para a harmonização.

4) Grupos de países com cultura e ambiente econômico similar e com modelos de normas contábeis similares podem ser identificados."

Outros pesquisadores estudam e analisam se deve existir ou não harmonização contábil.

Choi (1989) faz a seguinte pergunta: ${ }^{7}$

"Seria razoável impor uma contabilidade estreita sobre todos os relatórios existentes quando os estudos têm mostrado que os princípios e as práticas de contabilidade se baseiam no ambiente?".

\footnotetext{
${ }^{5}$ Grien, Raul. La integración económica como alternativa inédita para América Latina. México, 1994.

${ }^{6}$ Blake, John; Amat, Oriol. European Accounting. London, 1983. pag. 22

${ }^{7}$ Segundo Choi citado por Blake, John; Amat, Oriol. Op. citada. London, 1983.
} 
Samuel e Olga (1982) chegaram a uma similar conclusão baseada em uma análise dos requisitos contábeis no Egito em várias etapas.

Eles afirmam: 8 "Necessitamos considerar as necessidades da contabilidade em um país, particularmente os países em desenvolvimento, não só as necessidades das comunidades dos negócios internacionais”.

Esta visão de que existe um conflito entre as necessidades contábeis de companhias locais e as companhias internacionais, é afirmada por Wilson (1991):

"Parece ser contraproducente e imprudente impor requisitos inadequados aos relatórios financeiros de companhias locais para ajudar às corporações multinacionais, as quais estão tentando alcançar a concorrência internacional, ou facilitar a mútua cooperação sobre o intercâmbio internacional de estoques" 9.

Wilson afirma que alguma forma de dois tipos de relatórios seria a solução. Fanti (1971) chega a uma conclusão similar, fazendo uma análise das dificuldades para se alcançar a harmonização contábil:

"A pesquisa para a uniformidade é uma necessidade para se compreender e dispor de dados financeiros de outros países. Se em vez de procurar a uniformidade, os contadores desenvolvessem a reconciliação de sistemas em

\footnotetext{
${ }^{8}$ Segundo Samuel e Olga apud Blake, John; Amat, Oriol. Op. citada. London, 1983.

${ }^{9}$ Segundo Wilson citado por Blake, John; Amat, Oriol. Op. citada. London, 1983.
} 
forma fidedigna, isso significaria trasladar dados não conhecidos dentro de termos conhecidos" 10 .

Desta forma, segundo Fanti, com dois tipos de relatórios poder-se-ia conseguir a harmonização contábil, respeitando as características de cada país e também encontrando a reconciliação com as normas internacionais de contabilidade.

Aitken e Islam (1984) afirmam enfaticamente que os obstáculos para a harmonização internacional contábil podem ser superados. Por exemplo, eles afirmam que, no caso da legislação restritiva local:

"Os contadores têm uma óbvia responsabilidade de relatar às autoridades pertinentes a provável e indesejável conseqüência da legislação, e assim tentar corrigir a legislação" ${ }^{11}$.

Estes autores aceitam que o processo de harmonização contábil levará tempo e, no entanto, poderão usar contas comparáveis em base internacional.

Existe diferença entre harmonização e padronização, segundo a apostila de Lisboa: ${ }^{12}$

\section{“HARMONIZAÇÃO VERSUS PADRONIZAÇÃO}

Harmonização significa que diferentes padrões podem existir em diferentes países, desde que estejam em harmonia com a norma internacional.

\footnotetext{
${ }^{10}$ Segundo Fanti apud Blake, John; Amat, Oriol. Op. citada. London, 1983.

${ }^{11}$ Segundo Aitken e Islam citado por Blake, John; Amat, Oriol. Op. citada. London, 1983.

${ }^{12}$ LISBOA, Lázaro. FIPECAFI--FEA USP. Apostila: Contabilidade Internacional. São Paulo, 1998.
} 
Padronização, significa que deve existir um único padrão ou regra aplicável a todas as situações. Utopia.

\section{HARMONIZAÇÃO}

\section{Obstáculos:}

- O alto grau das diferenças entre as normas e práticas contábeis dos diversos países;

- A falta, em alguns países, de entidades de profissionais com poder de influência;

- Nacionalismo.

\section{Desvantagens:}

- Não reconhece que diferentes países precisam de normas diferentes, de acordo às suas especificidades culturais, legais e econômicas;

- A harmonização implica na redução de opções de práticas apropriadas;

- Dificulta o progresso da contabilidade por refutar práticas contábeis bem fundamentadas.

\section{Vantagens:}

- Comparabilidade na avaliação do desempenho de empresas em nível mundial;

- Maior facilidade para o ensino da contabilidade;

- Maior facilidade para transferência de pessoal entre as subsidiarias de uma multinacional.

- Maior facilidade para o acesso das empresas a recursos financeiros internacionais;

- Permite a harmonização de pré-requisitos para que as empresas possam ter seus papéis negociados em diferentes bolsas de valores."

Nas desvantagens o item sobre o impedimento do progresso da contabilidade deve referir-se ao fato de que as normas internacionais outorgam somente algumas opções possíveis, depois de analisar devidamente o tema. Mas deve-se afirmar também que as normas internacionais estão em contínua revisão e estudo. 
Nas vantagens da harmonização, uma das mais importantes é o fluxo de recursos econômicos e de profissionais entre empresas internacionais.

A importância das normas internacionais para conseguir a harmonização é salientada por Most:

"A análise do conteúdo das normas internacionais de contabilidade fornece algum progresso à uniformidade. Com cada nova norma, uma certa quantidade de uniformidade é acrescentada ao progresso em direção à harmonização.

As normas tendem a ser absolutas, mas os princípios de contabilidade tendem a ser circunstanciais. Com isso, normas flexíveis estão sendo promulgadas. Os acadêmicos e outros teóricos da contabilidade podem querer dar atenção às normas flexíveis para ver se condições circunstanciais podem ser desenvolvidas para o uso de cada alternativa". ${ }^{13}$

De acordo com o trabalho de Pereda, há um conjunto de estratégias que o profissional contábil deve assumir em confronto com a globalização e com a harmonização internacional: ${ }^{14}$

- "Elaborar e compartilhar uma teoria geral da Contabilidade;

- Pesquisar em profundidade as conseqüências e a relação mútua entre cenário e sistemas contábeis;

- Debater e chegar a um acordo em relação aos objetivos mais adequados para a informação contábil e sobre os requisitos que ela deve cumprir para satisfazer os objetivos;

- Pesquisar e chegar a um acordo sobre a definição e significado das hipóteses fundamentais de nossos sistemas contábeis, assim como da melhor forma de aplicá-las para garantir sua utilidade;

- Intensificar o estudo, baseado nas variáveis de seu cenário e nos objetivos e requisitos da informação financeira, das diferenças e similitudes entre os diferentes sistemas contábeis, assim como estabelecer sua classificação de acordo com essas variáveis;

\footnotetext{
${ }^{13}$ MOST, kenneth S. Advances in International Accounting. London, 1987.

${ }^{14}$ PEREDA, Jorge Tua. La armonización contable internacional. InterAmérica. Año III, N. 8, Enero Junio, 2000. pág. 70.
} 
- Discutir sobre a conveniência de elaborar um esquema conceptual para América do Sul e, se a resposta é positiva, a realização dele, chegando a um acordo sobre seu conteúdo;

- Pesquisar sobre as conseqüencias econômicas das normas contábeis e discutir uma estratégia para determinar quais serão consideradas;

- Chegar a um acordo sobre aquelas peculiaridades nacionais que a regulamentação contábil deve respeitar e deixar progredir, assim como sobre a forma de considerá-las;

- Pesquisar sobre a melhor forma de preparar nossos alunos, futuros profissionais da Contabilidade, para confrontar a constante mudança na realização de seu desempenho profissional."

Dentro deste conjunto de estratégias, pode-se destacar a importância da elaboração em conjunto de uma teoria geral da Contabilidade, assim como de um marco conceitual para a América do Sul.

Outro item importante que deve existir é uma conciliação das normas de contabilidade com as características e peculiaridades de cada país que devem ser respeitadas.

A importância de um marco conceitual também é salientada em um trabalho da Universidade de Buenos Aires, onde foram realizadas pesquisas entre Professores titulares de Contabilidade e Auditoria de Universidades Públicas e Privadas: ${ }^{15}$

"80\% dos professores consultados na Argentina consideraram correta uma introdução das normas contábeis. O fundamento é que é imprescindível porque falta explicitar os pressupostos básicos. A aplicação do marco teórico científico -técnico, que dá nascimento às normas e ao objetivo que estas perseguem, contribui a um melhor entendimento. Os que se manifestaram contrários à sua existência, justificamse dizendo que as normas devem ser suficientemente claras por elas mesmas.

\footnotetext{
${ }^{15}$ UNIVERSIDAD DE BUENOS AIRES, Facultad de Ciencias Económicas, Instituto de Investigaciones Contables "Profesor Juan Alberto Arévalo" Programación Científica 1998/2000 UBAC y T TRIENAL. Proyecto TE23: "Determinación de las "bases teóricas" para la armonización de normas contables en el MERCOSUR" Octubre de 2000. Pág. 12 e 13.
} 
Na análise realizada nas respostas de professores do Uruguai, foi observado que $82 \%$ consideram correta essa introdução às normas, $O$ fundamento é que estabelece um marco para interpretar as normas, e isso ajuda seu melhor entendimento e aplicação.

No caso do Brasil, o total das respostas considera correta uma introdução, já que é necessária para localizar o contexto e fundamento da norma e especificar o objetivo claramente."

\section{Importância do IASC no Processo de Harmonização}

O principal organismo que emite Normas Internacionais de Contabilidade é o IASC - International Accoounting Standards Committee, que foi criado em 1973.

Segundo dados de Pereda, ${ }^{16}$ a natureza do IASC é profissional porque não está apoiada no Direito Público, mas sim no acordo entre organizações de especialistas contábeis. Seu âmbito é mundial.

De acordo com a mesma fonte existem compromissos mútuos entre o IASC e o IFAC - Internacional Federation of Accountants, organismo que emite Normas Internacionais de Auditoria em nível mundial. Esses compromissos consistem no reconhecimento mútuo de ambas organizações e na cooperação e participação entre as duas.

Os objetivos do IASC são os seguintes: ${ }^{17}$

a) formular e difundir, em interesse do povo, normas contábeis a serem observadas na apresentação das demonstrações financeiras, e promover sua aceitação e respeito em todos os países do mundo, $e$

b) trabalhar pelo desenvolvimento e harmonização dos regulamentos, normas contábeis e procedimentos relacionados com a apresentação das demonstrações financeiras.

\footnotetext{
${ }^{16}$ PEREDA, Jorge Tua. Op. Citada. InterAmérica. Ano III, N. 8, Janeiro - Junho, 2000.

${ }^{17}$ PEREDA, Jorge Tua. Op. Citada. InterAmérica. Ano III, N. 8, Janeiro - Junho, 2000. p. 64.
} 
A qualidade das normas do IASC faz que este organismo possua um nível alto no campo internacional. O número de Normas Internacionais emitidas é superior a trinta e constituem um grande avanço na harmonização contábil.

Segundo Pereda, as características do "modelo" harmonizador do IASC são as seguintes: ${ }^{18}$

- "O caráter participativo da elaboração das Normas, manifestado não somente na atividade do Grupo Consultivo, mas também na intervenção das instituições membros e dos demais interessados nas distintas etapas do processo de emissão de uma norma.

- O formato escolhido para as Normas permite a justificação das alternativas contábeis escolhidas: a divisão entre parte expositiva, somente descritiva de conceitos e possibilidades de tratamento contábil; a parte normativa, onde é determinada a alternativa elegida, permite pensar na superioridade técnica do tratamento contábil e informativo que é considerado como obrigatório.

- A oportunidade dos temas abordados nas Normas IASC, que são situados entre os mais controvertidos no âmbito contábil, no momento em que foram escolhidos.

- O caráter dinâmico e evolutivo das normas em vigor, submetidas a permanente revisão.

- A quantidade de aplicações que o IASC tem conseguido dar às normas, que servem ou podem servir como regras contábeis diretamente aplicáveis a empresas multinacionais, ou de apoio para o desenvolvimento das normas nacionais, como de base para as normas supranacionais"

Não obstante a qualidade de suas normas, existem algumas críticas ao trabalho do IASC: ${ }^{19}$

- "A utilização do modelo contábil anglo-saxão, esquecendo outras possíveis alternativas.

- A concentração do poder de decisão em poucos países, apesar dos intentos do IASC por promover maior participação. ${ }^{20}$

\footnotetext{
${ }^{18}$ PEREDA, Jorge Tua. Op. Citada. InterAmérica. Ano III, N. 8, Janeiro - Junho, 2000. p. 68.

${ }^{19}$ PEREDA, Jorge Tua. Op. Citada. InterAmérica. Ano III, N. 8, Janeiro - Junho, 2000. p. 68 e 69.

${ }^{20} \mathrm{O}$ comentário de Pereda pode referir-se à predominância dos países desenvolvidos.
} 
- A excessiva prioridade do cálculo do lucro, que pode deixar em posição secundária outros objetivos da informação financeira como mostrar a situação patrimonial da entidade ou sua capacidade na geração de liquidez.

- $\quad$ A ausência de formatos de apresentação das demonstrações financeiras.

- Por último, a permissibilidade das alternativas contábeis a serem aceitas, possivelmente condicionada pelos desejos dos diferentes países em que são praticadas.

Neste último item deve-se indicar que há muitos anos, o IASC colocou em funcionamento o "projeto de comparabilidade", destinado a reduzir o número de alternativas possíveis existentes em suas Normas".

$\mathrm{Na}$ atualidade todas as normas já foram revisadas com este critério.

A influência do IASC é, de acordo com Pereda, constante nos diferentes países, e nos organismos internacionais como a OCDE - Organização para a Cooperação e o Desenvolvimento Econômico, e principalmente no IOSCO - The International Organization of Securities Commissions, organização que reúne aos organismos que gerenciam as bolsas de valores.

\section{3.- HIPÓTESE}

Uma análise preliminar dos pontos positivos descritos a seguir permite presumir que o processo de harmonização contábil na América do Sul tem possibilidades de sucesso. Nos últimos dois anos vem sendo implementada uma iniciativa de aprimoramento da profissão contábil sob a denominação de IFAD International Forum for Accounting Development. Deixamos de aprofundar comentários a respeito neste trabalho porque o IFAD ainda não está consolidado nesta data. 
Entre tais pontos positivos temos:

1) a mudança do modelo de protecionismo em favor das idéias neoliberais que constituem a essência do novo modelo de abertura. O princípio geral deste modelo é a liberdade econômica fundamentada no mercado. A Bolívia iniciou tal mudança na segunda metade da década de 1980, depois a Venezuela fez o mesmo, a Colômbia adotou a tendência em 1990, o mesmo que o Peru. A Argentina, o Brasil, o Paraguai e o Uruguai também adotaram este modelo desde 1991 com a criação do Mercosul;

2) o fato de que os países integrantes da América do Sul tenham hoje governos democráticos influi positivamente na evolução dos sistemas contábeis, pois existe tendência a menor ingerência do Estado e mais espaço para a autoregulação profissional;

3) o crescente estudo da contabilidade e dos relatórios financeiros em livros, revistas e jornais nacionais na região sob estudo;

4) a tendência à utilização das normas do IASC - International Accounting Standards Committee pelos países latinos, em duas formas: através da adoção direta dessas normas ou inspirando-se nelas para a criação de suas próprias normas;

5) o crescimento de empresas multinacionais e sua influência nos países da América do Sul. 
Os principais aspectos negativos que influem sobre a harmonização contábil podem ser resumidos como segue:

1) econômicos, Mónica Hirst diz:

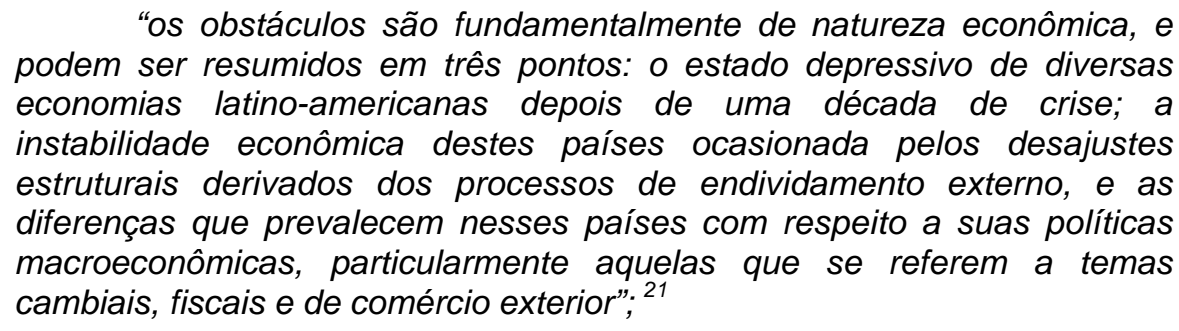

2) a diferença de sistemas contábeis entre os países, já que estes refletem o ambiente de cada país;

3) os diferentes objetivos e propósitos das demonstrações financeiras que provocam práticas contábeis diferentes entre os diversos países;

4) o desenvolvimento diferente dos profissionais em contabilidade entre tais países;

5) os diferentes sistemas legais e a influência das legislações fiscais sobre a contabilidade;

6) os diferentes níveis de desenvolvimento econômico que tendem a influir na atividade contábil.

\footnotetext{
${ }^{21}$ HIRST, Mónica. Condicionantes y motivaciones del Proceso de Integración. Intal. N.175, p.19-31, ene/feb 92.
} 
As condições ambientais que influenciam os sistemas contábeis são, de acordo com Previts, as seguintes:
“1) estabilidade da moeda em circulação;
2) natureza da propriedade dos negócios;
3) nível de sofisticação da administração;
4) tamanho e complexidade dos negócios;
5) velocidade da inovação tecnológica e comercial;
6) presença de legislação específica em contabilidade;
7) tipo de economia e grau de liberdade do mercado;
8) modelo de desenvolvimento da economia;
9) condição da educação em contabilidade;
10) condição da profissão contábil;
11) nível geral da educação pública;
12) extensão do conhecimento financeiro que requeira a existência de sofisticados relatórios financeiros à disposição da comunidade de usuários;
13) estrutura legal e usual de negócios e finanças." 22

\section{4.- DELIMITAÇÕES}

A harmonização contábil na América do Sul é um tema muito amplo, e devido a isto, o presente trabalho, depois de apresentar uma sinopse do Mercosul e da Comunidade Andina, concentrará sua atenção no estudo do Marco Conceitual Contábil destes países e, posteriormente, nas principais semelhanças e diferenças nas normas contábeis no âmbito de cinco países da América do Sul: Argentina, Brasil, Colômbia, Peru e Venezuela, por serem fatores relevantes que influenciam a harmonização contábil.

Estes países foram considerados para o trabalho devido a possuirem maior número de habitantes e terem o seu Produto Interno Bruto maior, dentro de seu bloco respectivo. 


\begin{tabular}{|c|c|c|}
\hline $\begin{array}{c}\text { COMUNIDADE ANDINA } \\
\text { Dados 1999 }\end{array}$ & Habitantes & P.I.B. (bilhões de \\
\hline BOLÍVIA & 8,1 & Dólares) \\
\hline COLÔMBIA & 41,6 & 8,9 \\
\hline EQUADOR) & 12,4 & 97,3 \\
\hline PERU & 25,2 & 13,7 \\
\hline VENEZUELA & 23,7 & 63,6 \\
\hline
\end{tabular}

Fonte: http://www.comunidadandina.org

\begin{tabular}{|c|c|c|}
\hline MERCOSUL & Habitantes & P.I.B. (bilhões de \\
\hline Dados 1999 & (milhões) & Dólares) \\
\hline
\end{tabular}

\footnotetext{
${ }^{22}$ Segundo Previts citado por Most, Kenneth. Advances in International Accounting. London, 1987.
} 


\begin{tabular}{|c|c|c|}
\hline ARGENTINA & 36,6 & 281,9 \\
\hline BRASIL & 163,7 & 761 \\
\hline PARAGUAI & 5,4 & 8,5 \\
\hline URUGUAI & 3,3 & 20,1 \\
\hline
\end{tabular}

Fonte: http://www.mercosur.org

A Argentina, o Brasil e o Peru foram escolhidos também devido a que suas taxas de inflação foram diminuindo desde 1990 até 2000.

Os cinco países escolhidos possuem um déficit baixo, menor que $3 \%$ do Produto Nacional Bruto de seu país.

A Argentina e o Brasil possuem uma economia altamente industrial.

A Colômbia, o Peru e a Venezuela realizam exportações intra-comunitárias com maior grau de elaboração em relação aos outros países da CAN.

A Argentina, o Brasil e o Peru viveram, na última década, longos períodos de taxa de câmbio estável da moeda nacional em relação ao dólar.

\section{5.- OBJETIVO}

Nosso objetivo principal é o estudo de dois tipos de fatores que influenciam o processo de harmonização contábil no Mercosul e na Comunidade Andina: 
- A análise das semelhanças e diferenças dos Marcos Conceituais Contábeis dos cinco países.

- As principais semelhanças e diferenças nas normas contábeis de cinco países: Argentina, Brasil, Colômbia, Peru e Venezuela.

Depois de realizar a análise e o estudo das normas desses países em relação a esses temas, serão apresentadas conclusões sobre a existência ou não da harmonização contábil entre eles.

\section{6.- METODOLOGIA}

A pesquisa segue um método conceitual - comparativo, já que examina, estuda e compara alguns dos princípios de contabilidade dos países citados e algumas das diferenças entre as normas de contabilidade desses países.

Utiliza também o método descritivo porque analisa minuciosamente algumas das normas contábeis dos cinco países escolhidos.

O trabalho será estruturado em cinco capítulos, com os seguintes conteúdos:

Capítulo 1: Introdução, incluindo a apresentação do tema, antecedentes, problema, hipótese, delimitações do estudo, objetivos, relevância e metodologia a ser utilizada. 
Capítulo 2: Será apresentado o Processo de Integração na América do Sul. A origem, os objetivos do Mercosul e da Comunidade Andina; e a relação entre ambos os blocos da América do Sul.

Capítulo 3: Apresentam-se os Marcos conceituais contábeis dos cinco Países.

Capítulo 4: Serão apresentadas as principais semelhanças e diferenças nas normas contábeis dos cinco países citados.

Capítulo 5: Neste capítulo, apresenta-se um resumo com os resultados finais do trabalho.

\section{7.- JUSTIFICATIVA}

Em parte devido à globalização, que influi no âmbito econômico, político e social, existe um alto grau de crescimento e desenvolvimento das economias, sobretudo nos países desenvolvidos, existindo também incerteza econômica, instabilidade e crise nos países em desenvolvimento, influenciando todos os habitantes do mundo e transcendendo as fronteiras dos países.

Existe também a regionalização, dividindo o mundo em blocos. Tudo isto provoca uma distribuição diferente ou assimétrica do mundo, fazendo necessária a harmonização.

No campo contábil, a harmonização está progredindo bastante. Organismos internacionais como o IASC, que emite Normas Internacionais de 
Contabilidade, o IFAC - International Federation of Accountants, que emite, entre outros pronunciamentos, Normas Internacionais de Auditoria, a União Européia e o Comitê de Normas Contábeis do Mercosul, realizam esforços para alcançar a harmonização contábil, colocando como principal objetivo a emissão de normas profissionais de alta qualidade no campo contábil.

A harmonização contábil nos países da América do Sul forma parte de um processo maior de integração econômica, onde a formação de uma área de livre comércio pode ajudar a integração da América do Sul. Neste processo a harmonização da contabilidade, que é a língua econômica dos povos, é muito importante para o desenvolvimento do comércio, a atração de investimentos e para a inserção no mercado econômico internacional.

Este processo de integração da América do Sul pode não limitar-se somente à área econômica, talvez devendo compreender também outras áreas, como educação, pesquisa científica, tecnológica, deve permitir também o confronto de idéias, e o desenvolvimento das características e identidades dos povos da Região. 


\section{2. - O PROCESSO DA I NTEGRAÇÃO NA AMÉRI CA DO}

\section{SUL}

\section{1.- ASPECTOS GERAIS DA COMUNIDADE ANDINA}

A Comunidade Andina é uma organização que teve sua origem em 1969 com o Acordo de Cartagena assinado em Bogotá, na República da Colômbia.

$\mathrm{Na}$ atualidade, está composto por cinco países: Bolívia, Colômbia, Equador, Peru, e Venezuela. Tem caráter de pessoa jurídica internacional e seus órgãos e instituições constituem o denominado Sistema Andino de Integração (SAI). 
De acordo com dados de sua página na internet, ${ }^{23}$ este bloco econômico está composto por mais de 111 milhões de habitantes em uma área de 4.700 .000 km². Em 1999, seu Produto Interno Bruto foi de 272 bilhões de dólares.

A Comunidade Andina, durante seus trinta e um anos, passou por várias etapas. No início foi chamada de "Acordo de Cartagena" ou "Grupo Andino".

"De uma concepção basicamente fechada de integração para dentro, de acordo com o modelo de sustituição de importações, reorientou-se a um esquema de regionalismo aberto. O grau de avanço na integração e os novos desafios derivados das mudanças na economia mundial provocaram a necessidade de introduzir reformas no Acordo de Cartagena.,24

O resultado dessas reformas foi a constituição da Comunidade Andina que iniciou suas atividades em $1^{0}$ de agosto de 1997, através de sua Secretaria Geral de caráter executivo, cuja sede está em Lima (Peru).

Para saber em que etapa do processo de integração está a Comunidade Andina, deve-se analisar as etapas desse processo:

"Todo processo de integração passa por diferentes etapas que são diferenciadas entre si pelo grau de profundidade dos compromissos que assumem seus países membros. Em uma Região de Livre Comércio -considerada como a primeira etapa-, o único compromisso é a abertura recíproca dos mercados nacionais, que se consegue eliminando tarifas e restrições ao comércio, em uma União Aduaneira, à abertura interna adiciona-se a adoção de uma tarifa externa para importações provenientes dos não sócios; e em um Mercado Comum, agrega-se à liberação do comércio de bens e serviços, a dos capitais e da mão de obra.

\footnotetext{
${ }^{23} \mathrm{http}: / /$ www.comunidadandina.org

${ }^{24} \mathrm{http} / / /$ www.comunidadandina.org
} 
A Comunidade Andina terminou com sucesso a liberação do comércio de bens entre seus países membros e está avançando na dos serviços. Adotou uma tarifa externa comum para as importações provenientes dos não sócios, conseguindo configurar uma União Aduaneira, mas ainda imperfeita. ${ }^{25}$

Pode-se concluir que na Comunidade Andina foi formada a Região de Livre Comércio, em 1993, com Bolívia, Colômbia, Equador e Venezuela. O Peru passou a formar parte da Região de Livre Comércio em 1997, devido a sua saída em 1992.

A União Aduaneira também está realizando-se, mas é ainda imperfeita devido à não participação de todos os membros.

O objetivo imediato da CAN, quando estiver praticamente concluída a região de livre comércio, é construir um mercado comum onde exista a plena mobilidade dos fatores produtivos, e também a integração entre os diversos setores e instituições que formam parte da sociedade civil das nações andinas.

O prazo para a constituição desse mercado é 2005.

\section{Indicadores macroeconômicos}

A Secretaria Geral da Comunidade Andina, de acordo com a base de dados estatísticos que possui, mostra os seguintes indicadores: ${ }^{26}$

De acordo com dados da CAN, se observa no quadro de Crescimento do PIB que, até a década de 70 , os países membros tiveram uma taxa constante de

\footnotetext{
${ }^{25}$ http://www.comunidadandina.org/

${ }^{26} \mathrm{http}: / /$ www.comunidadeandina.org/
} 
crescimento anual média maior que $5 \%$. No final dos anos 70 , houve uma baixa no ritmo de crescimento.

A década de 80, chamada a década errada para América do Sul, influenciou os países da CAN, com exceção da Colômbia que, apesar de reduzir seu ritmo de crescimento, este continua sendo positivo. Na década de 80 , as economias andinas na média apenas cresceram. Em termos per cápita, o crescimento é negativo. Na década de 90, os países retornam a seu crescimento, mas num ritmo menor que nos anos 60 e 70. 
Produto Interno Bruto Real Total

(Taxa de Crescimento Anual dos Valores Constantes)

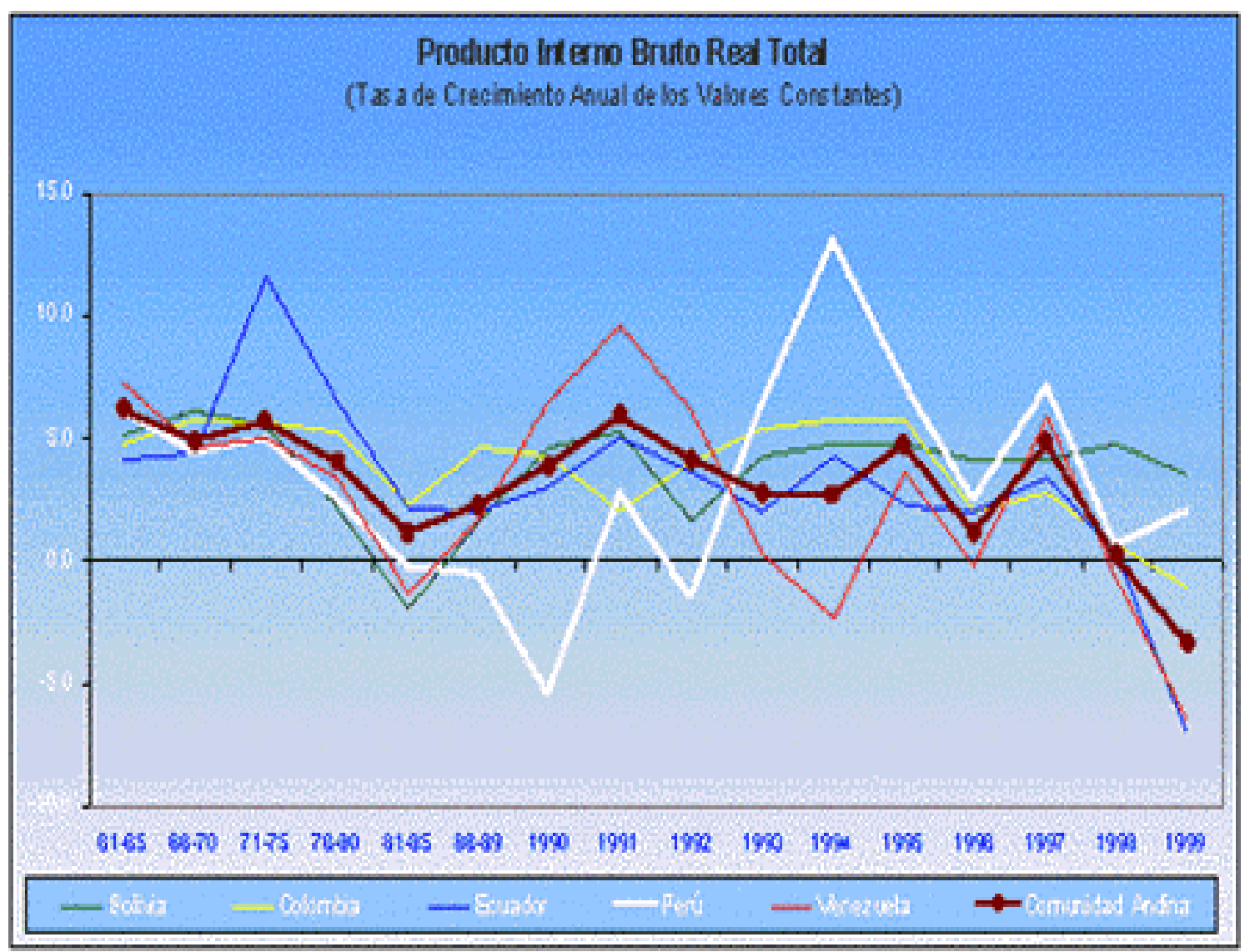

Fonte: http://www.comunidadandina.org 
No quadro de Variabilidade da taxa de crescimento do PIB em relação à média da CAN se observa que a variabilidade foi incrementada desde níveis de $1,4 \%$ nos anos 60 e 70 até $2,6 \%$.

A evolução da variabilidade se deve às conseqüências das mudanças dos países para ajustar seu modelo de desenvolvimento, como por uma configuração, que em nível mundial é mais volúvel, especialmente com a expansão e integração dos mercados de capitais.

Destaca a Bolívia que devido a suas mudanças entre 1985-86, teve um crescimento constante desde 1993. O segundo país com menor volubilidade é a Colômbia, mas, a partir de 1996, sua situação foi piorando. Os outros países tiveram altas e baixas muito pronunciadas. 
Variabilidade da taxa de crescimento do PIB em relação à média da CAN

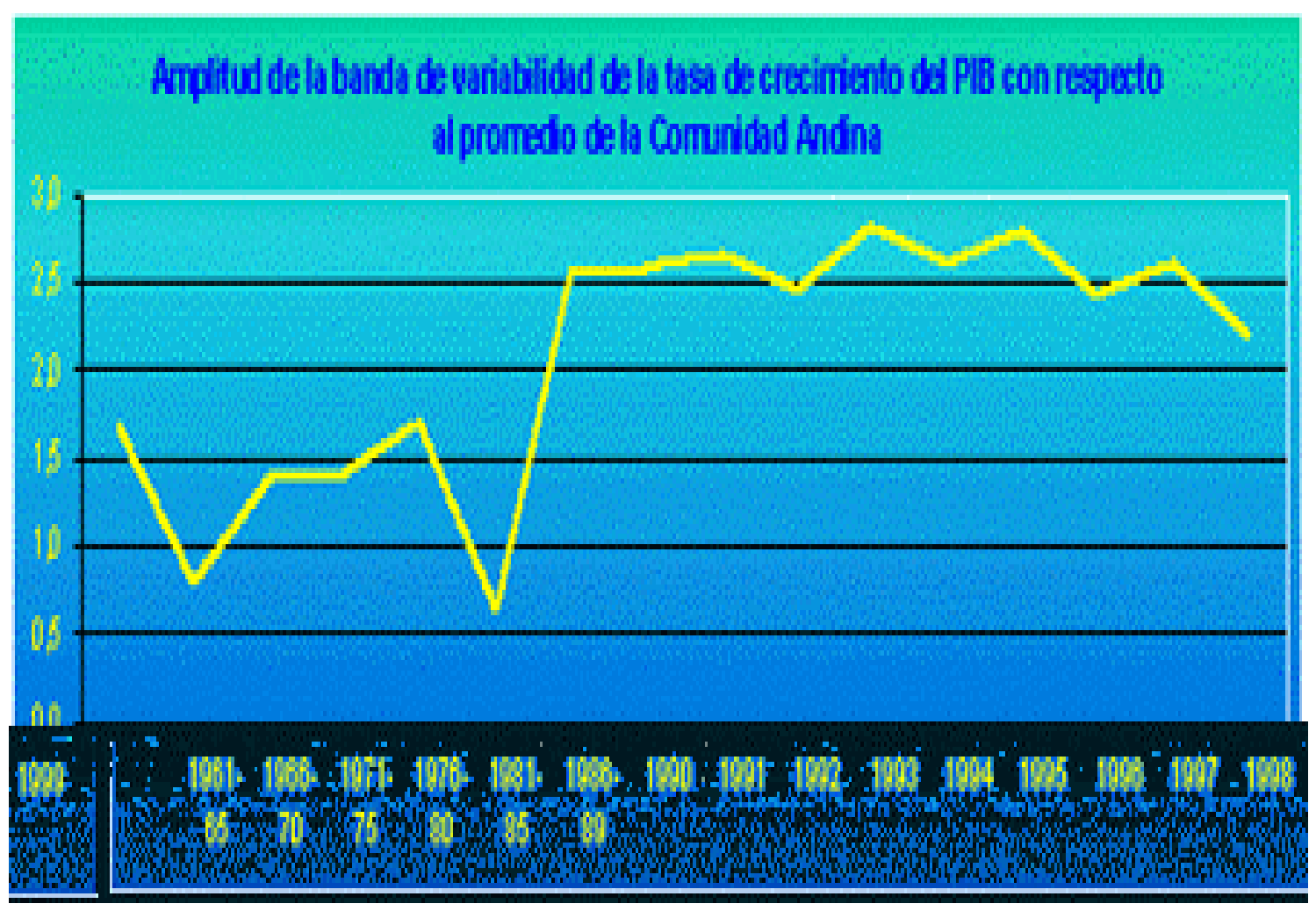

Fonte: http://www.comunidadandina.org 
No quadro de Formação Bruta do Capital Fixo como Porcentagem do PIB se observa que houve uma baixa nos investimentos de Capital Fixo desde a década de 80 , que não foi possível recuperar. O investimento público teve uma forte diminuição. Já o investimento privado, aumentou, mas não na medida suficiente. Os países com menor investimento foram o Equador, a Venezuela e a Bolívia.

No quadro Investimento Estrangeiro Direto Anual como Porcentagem do PIB vemos que tal investimento foi incrementado fortemente a partir de 1994. A Bolívia recebeu o maior investimento, atingindo nos dois últimos anos até $10 \%$ de seu PIB.

O Peru e a Colômbia seguem a Bolívia, mas principalmente devido às receitas pelas privatizações nos últimos anos. O Equador, que não desenvolveu este tipo de esquema, foi também favorecido por Investimentos Estrangeiros Diretos (IED). A Bolívia teve a maior importação de bens de capital. 
Formação Bruta do Capital Fixo como Porcentagem do PIB

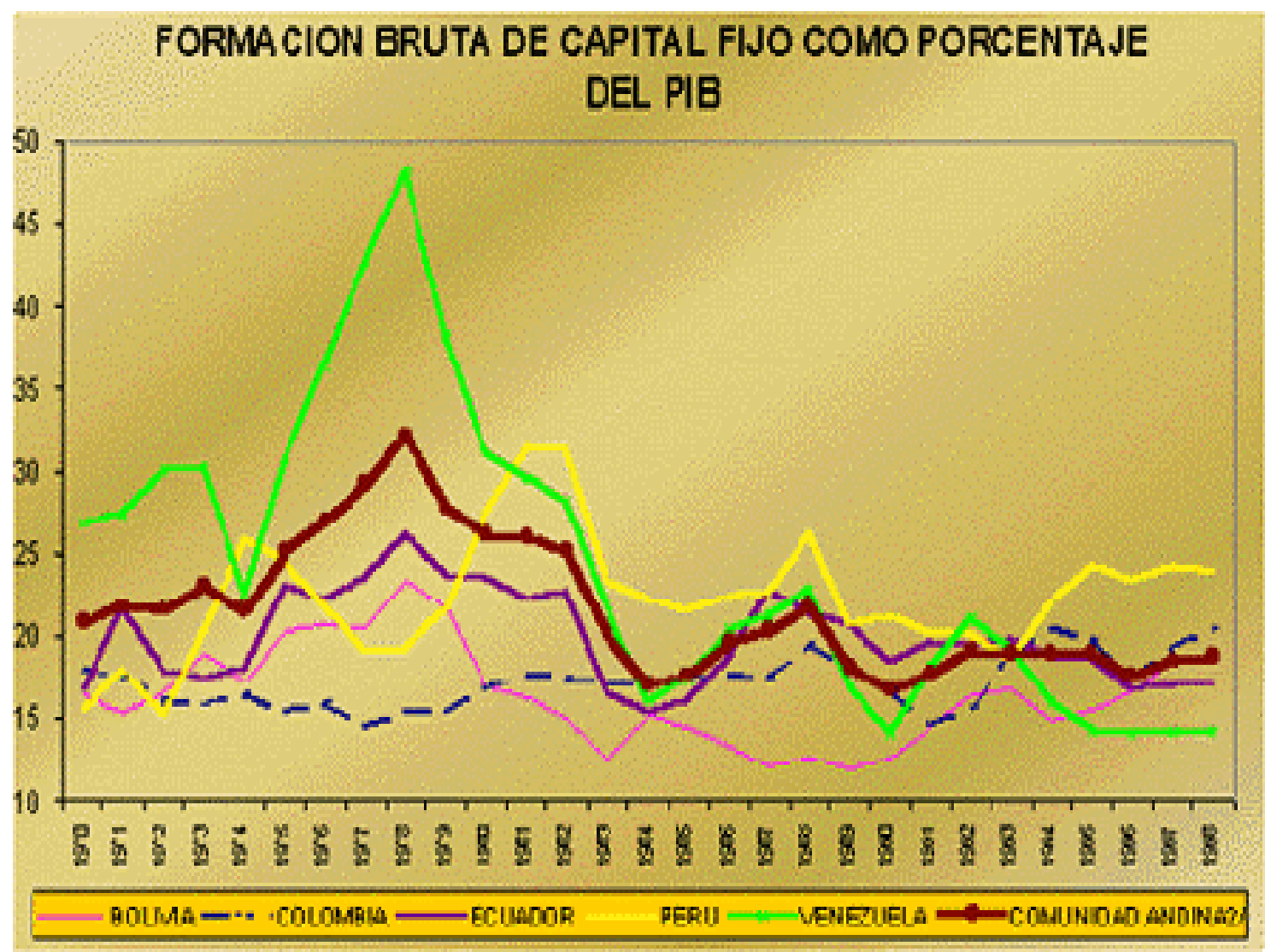

Fonte: http://www.comunidadandina.org 


\section{Comunidade Andina:}

Investimento Estrangeiro Direto Anual como Porcentagem do PIB

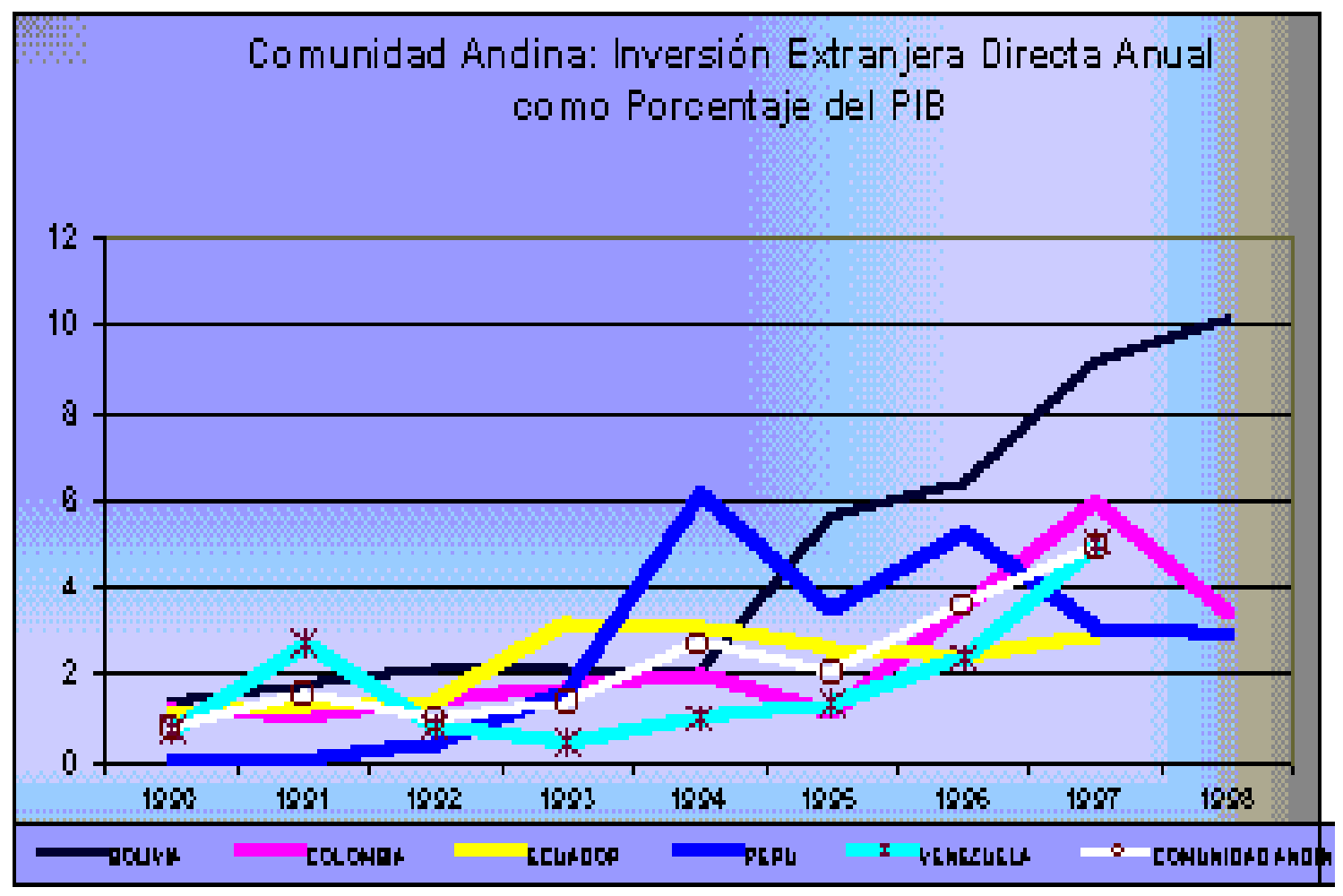

Fonte: http://www.comunidadandina.org 
No quadro do Comércio Internacional pode-se observar que as importações de bens tiveram incremento de $4 \%$ do PIB na média dos países do CAN. A Bolívia e o Equador, devido ao tamanho de suas economias, têm os indicadores mais altos, superiores a $20 \%$ do seu PIB nos dois últimos anos.

Cada país tem um diferente nível de exportação. Destacam-se o Equador e a Venezuela por serem exportadores de petróleo. 


\section{Comércio Internacional}

\section{Comunidade Andina: Importações de Bens FOB/PIB}

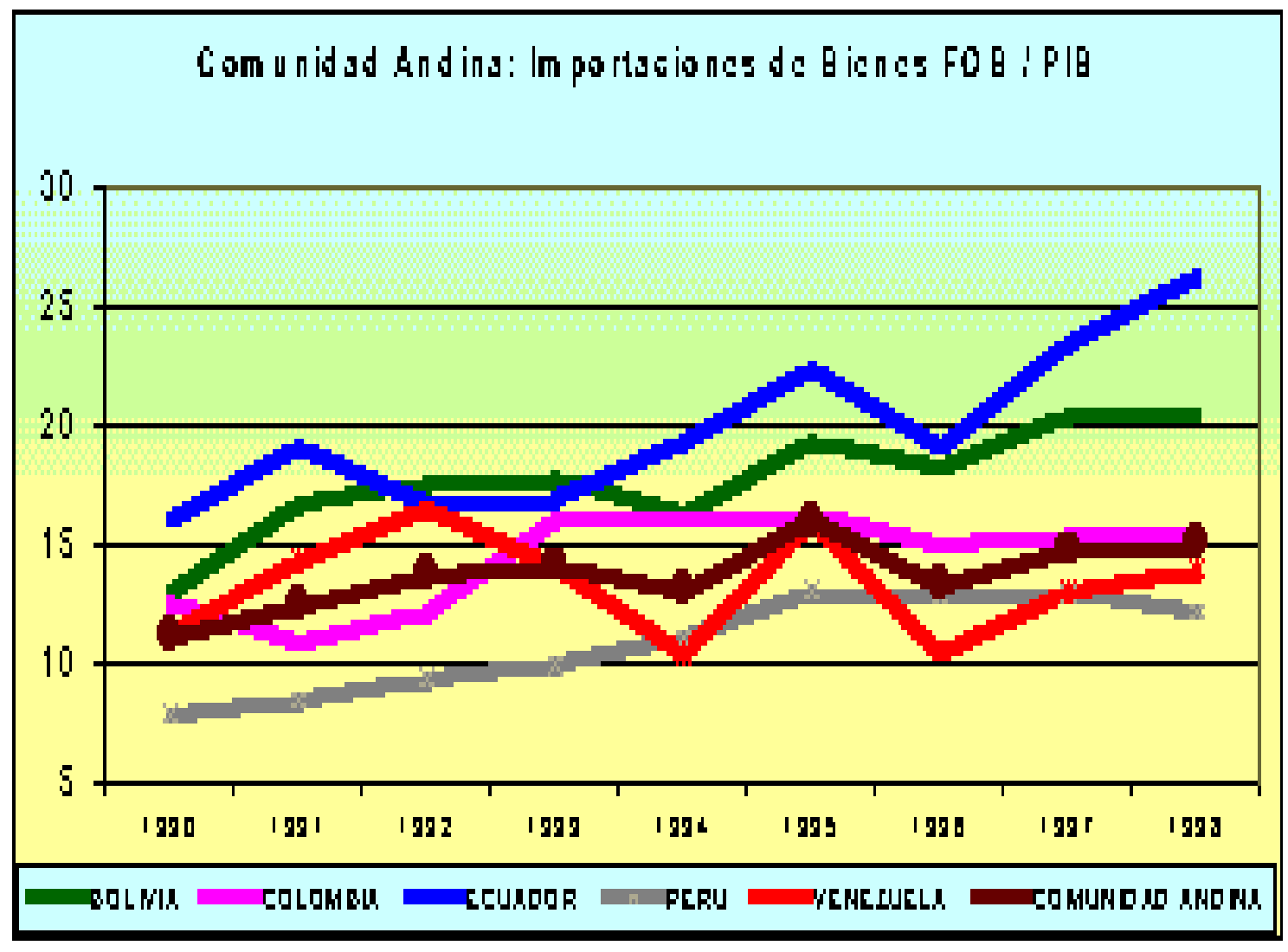

Fonte: http://www.comunidadandina.org 
Comunidade Andina: Exportações FOB/PIB

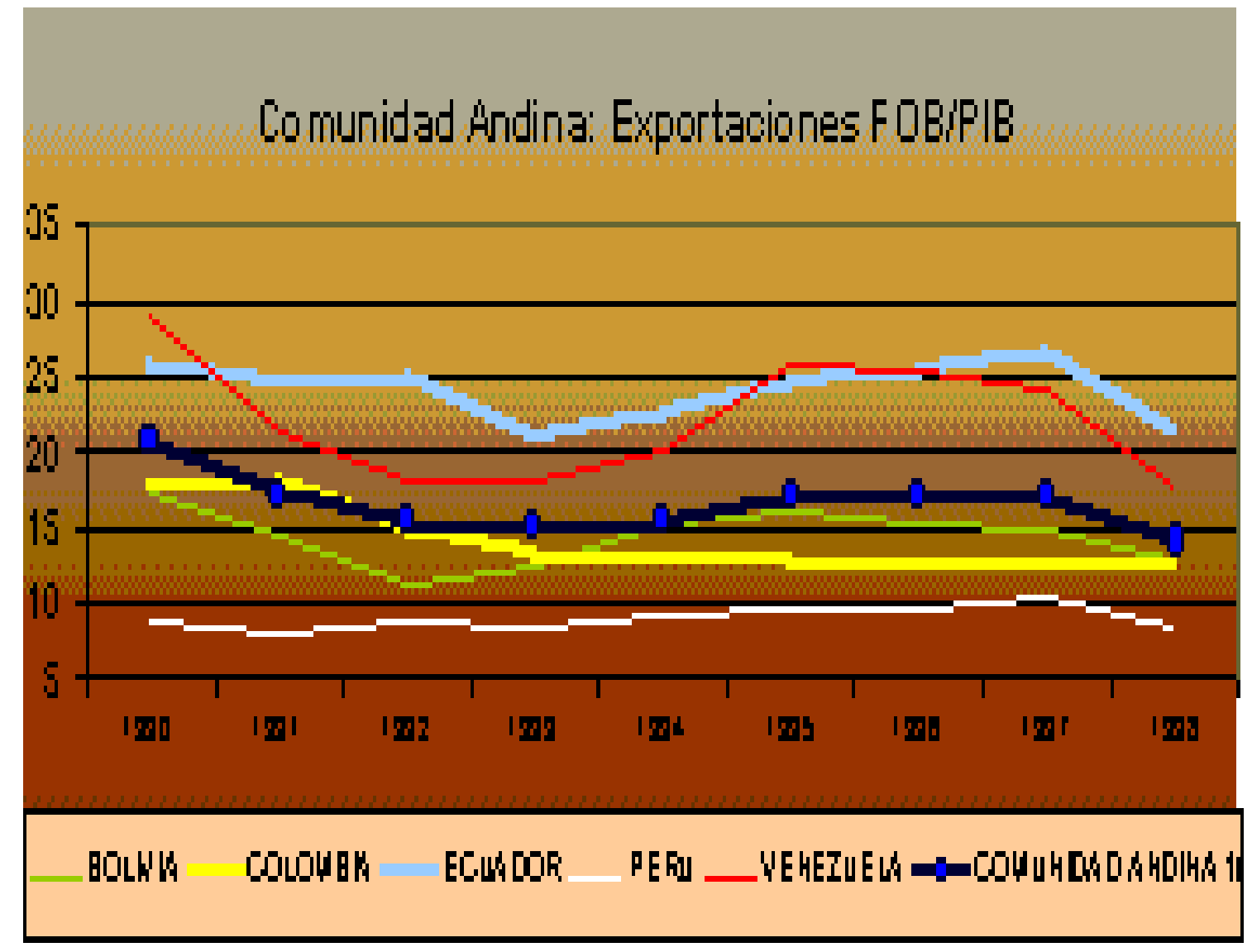

Fonte: http://www.comunidadandina.org 
No quadro de Relação do comércio intra-subregional e com o total (mundo) vemos que a importância do mercado andino cresceu bastante nos anos 90 . Na relação do comércio sub-regional com o mercado total (mundo), observamos que o primeiro cresceu entre 1990 e 1998 a 12\% (em 1970 o crescimento era de 5\%).

Nas exportações intra-comunitárias prevalecem os bens manufaturados, não obstante nas exportações destinadas ao resto do mundo predominarem os produtos básicos.

As exportações de produtos manufaturados, que em 1990 e 1991 constituiam 80\% do comércio intracomunitário, aumentaram em 10\% para 1998.

Nos produtos com maior grau de elaboração, salienta-se a Colômbia com $70 \%$ de suas exportações intra-comunitárias. Depois, seguem a Venezuela e o Peru.

No quadro de Resultado em conta corrente da Balança de Pagamentos vemos que a influência do comércio da CAN foi refletida no resultado em conta corrente da Balança de Pagamentos, e sua viabilidade a longo prazo depende da geração de maiores exportações através da adequação e conversão do setor exportador ao mercado internacional, e do aumento da eficiência e competitividade deste setor. 
Relação do comércio intra-subregional e com o total (mundo)

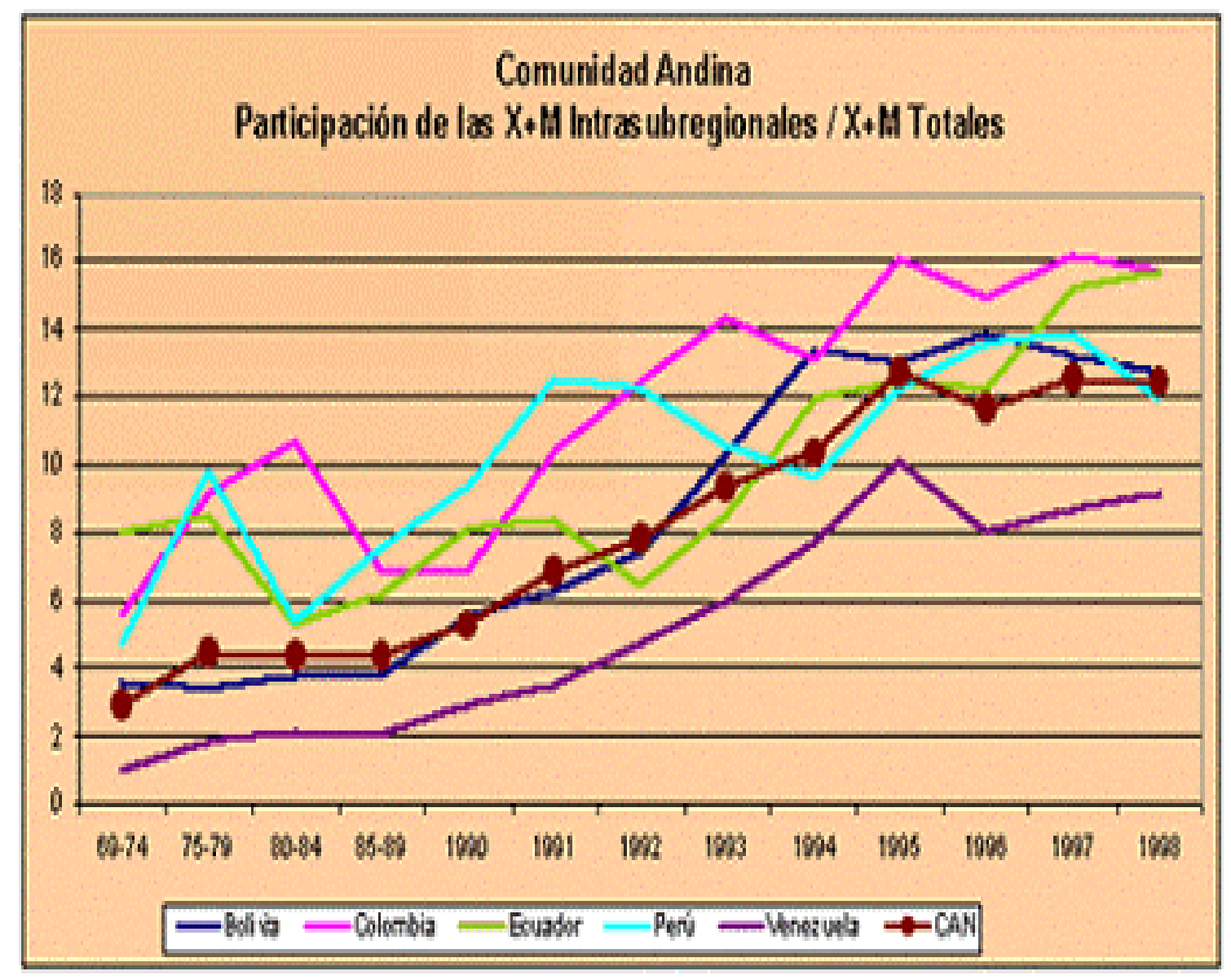

Fonte: http://www.comunidadandina.org 
Exportações intra-comunitárias: Produtos manufaturados

com maior grau de elaboração

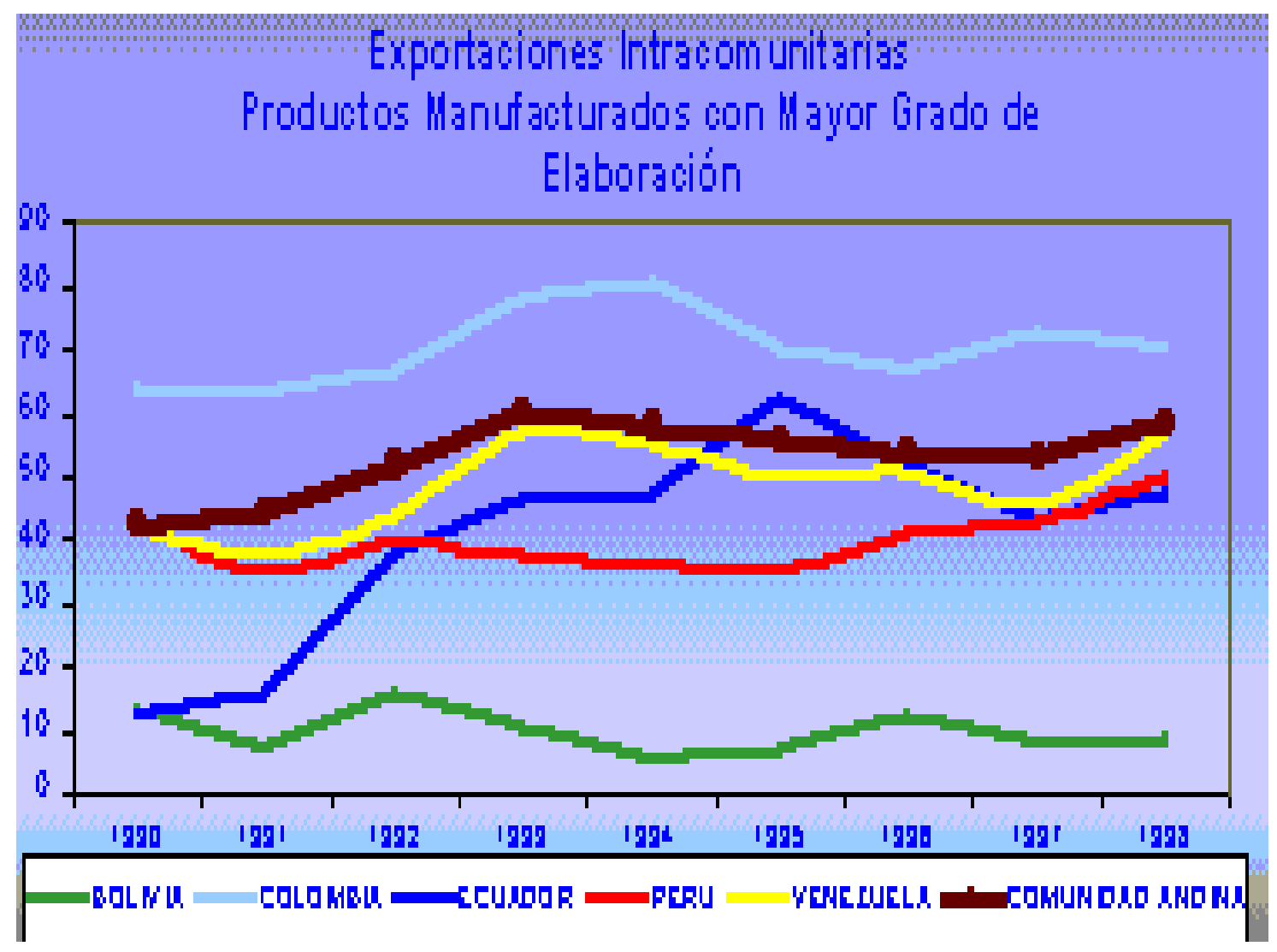

Fonte: http://www.comunidadandina.org 
Resultado em conta corrente da Balança de Pagamentos (\% do PIB)

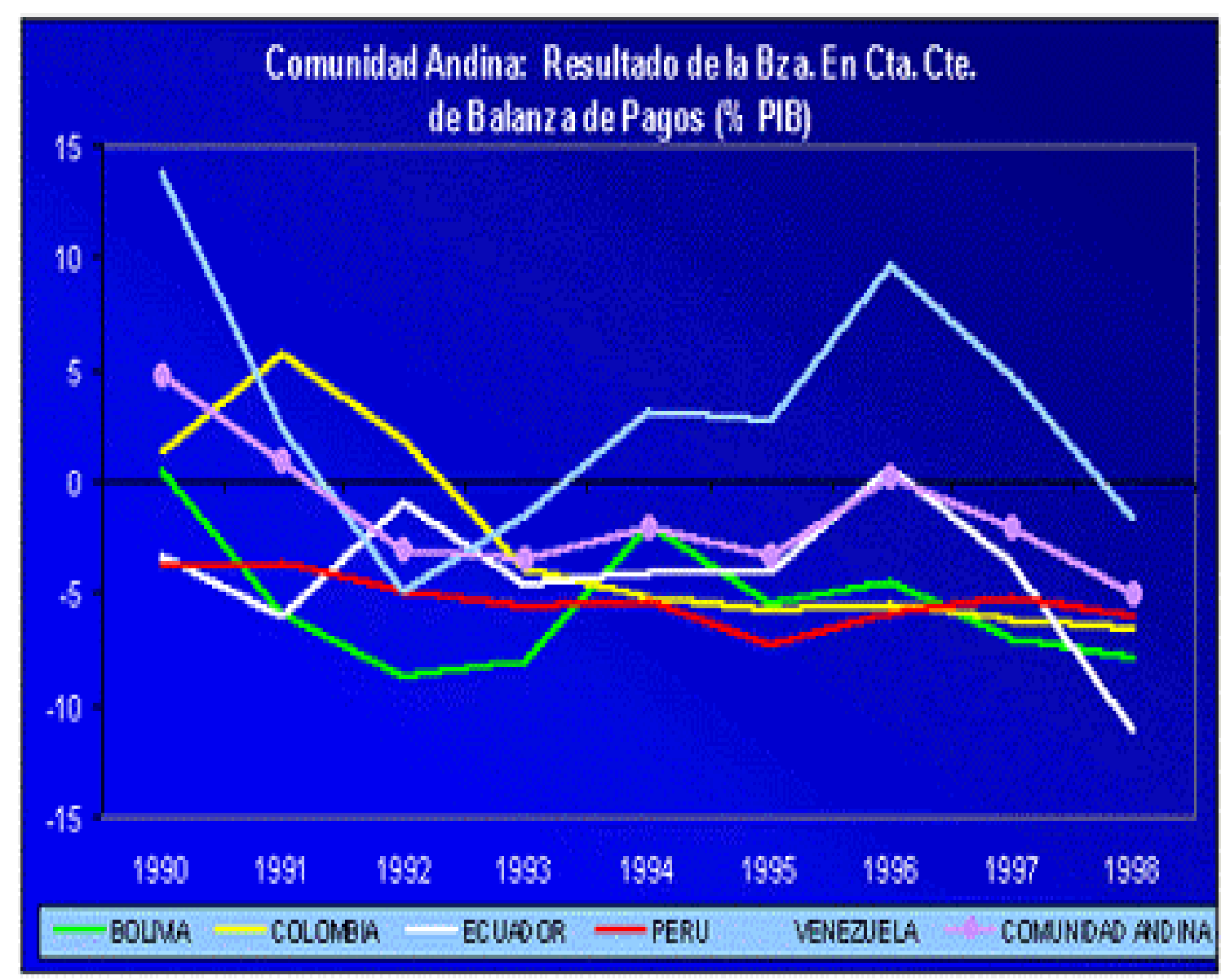

Fonte: http://www.comunidadandina.org 


\section{QUADRO COMPARATIVO DOS TRINTA ANOS DA CAN}

\begin{tabular}{|c|c|c|c|c|}
\hline VARIÁVEL & UNIDADES & 1970 & 2000 & CRESCIMENTO \\
\hline População & Milhões de habitantes & 55 & 113 & 2 vezes \\
\hline Produto Interno Bruto & Bilhões de dólares & 28,6 & 269,7 & 9 vezes \\
\hline PIB por habitante & Dólares & 515 & 2.387 & 5 vezes \\
\hline $\begin{array}{c}\text { Exportações ao } \\
\text { mundo }\end{array}$ & Bilhões de dólares & 5,4 & 57,4 & 11 vezes \\
\hline $\begin{array}{l}\text { Exportações intra- } \\
\text { comunitárias }\end{array}$ & Milhões de dólares & 111 & 5.167 & 47 vezes \\
\hline $\begin{array}{c}\text { Participação nas } \\
\text { exportações ao } \\
\text { mundo }\end{array}$ & Porcentagem & $2 \%$ & $9 \%$ & 5 vezes \\
\hline $\begin{array}{l}\text { Importações ao } \\
\text { mundo }\end{array}$ & Bilhões de dólares & 4,1 & 39,6 & 10 vezes \\
\hline $\begin{array}{l}\text { Participação no Total } \\
\text { intra-comunitário }\end{array}$ & Porcentagem & $48 \%$ & $86 \%$ & 2 vezes \\
\hline Inflação & $\begin{array}{c}\text { Dez. respeito a dez. ano } \\
\text { anterior }\end{array}$ & $8 \%$ & $17 \%$ & 2 vezes \\
\hline $\begin{array}{l}\text { Investimento } \\
\text { estrangeiro } \\
\text { acumulado }\end{array}$ & Bilhões de dólares & 3,4 & 69,5 & 20 vezes \\
\hline $\begin{array}{l}\text { Investimento intra- } \\
\text { comunitário acumul. }\end{array}$ & Milhões de dólares & 15 & 810 & 54 vezes \\
\hline
\end{tabular}


FONTE: COMUNIDADE ANDINA - Secretaria Geral, Sistema Subrebional de informação Estatística, Decisão 115 ELABORAÇÃO: COMUNIDADE ANDINA - Secretaria Geral, Projeto 5.2 .5 - Estatística citado por

5.2.5 - Estatística citado por http://www.comunidadandina.org

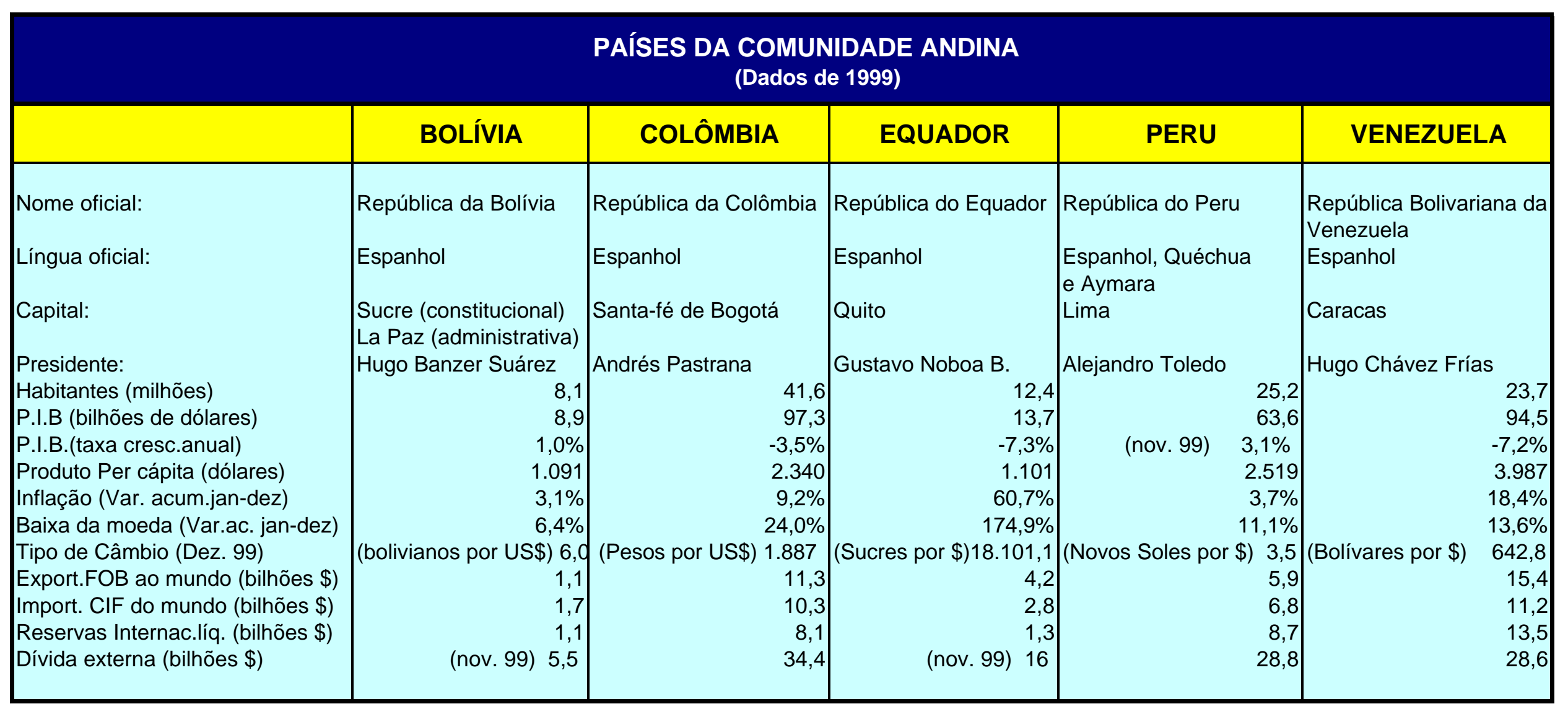

Fonte: http://www.comunidadandina.org 


\subsection{1.- OBJETIVOS DA COMUNIDADE ANDINA:}

Definidos pelos Presidentes andinos no documento "Desenho Estratégico ou Nova Agenda da Integração" ${ }^{27}$, eles são:

- "aprofundar o processo da integração andina, elevando os resultados obtidos no campo comercial, e colocá-lo a serviço dos objetivos de um desenvolvimento econômico e social;

- harmonizar políticas econômicas, adequando-as para o desenvolvimento contínuo e o alcance de políticas eficientes;

- definir políticas sociais orientadas à elevação da qualidade de vida e ao melhoramento do acesso dos diversos grupos sociais da sub-região aos benefícios do desenvolvimento;

- articular o Sistema Andino de Integração (SAl) para superar os novos desafios da integração;

- avançar até a integração latino-americana e do hemisfério."

\subsection{2.- ESTRUTURA INSTITUCIONAL DA COMUNIDADE ANDINA}

A estrutura institucional da CAN foi modificada no Protocolo de Trujillo (Peru) em 1996. O Sistema Andino de Integração (SAI) tem como finalidade permitir uma coordenação efetiva dos órgãos e instituições da Comunidade Andina.

De acordo com a página de Internet da $\mathrm{CAN},{ }^{28}$ o SAl é composto pelos seguintes órgãos e instituições:

\footnotetext{
${ }^{27}$ Comunidade Andina. http://www.comunidadandina.org
} 
"Conselho Presidencial Andino.- É o órgão máximo do SAl e é formado pelos Chefes de Estado dos Países Membros da CAN. Emite Diretrizes sobre os diferentes âmbitos da integração da sub-região andina.

- Conselho Andino de Ministros de Relações Exteriores.- É composto pelos Ministros de Relações Exteriores dos países da CAN e tem como funções formular, executar e avaliar a política geral do processo de integração da subregião andina, em coordenação com a Comissão. Os Pronunciamentos que emite são chamados de Declarações e Decisões, adotadas por consenso.

- Comissão da Comunidade Andina.- É o órgão que tem como funções formular, executar e avaliar a política geral do processo de integração da subregião andina na área de comércio e investimentos em coordenação com o Conselho Andino de Ministros de Relações Exteriores. É constituído por um representante plenipotenciário de cada um dos países-membro do CAN. Emite Pronunciamentos chamados Decisões.

- Secretaria Geral da Comunidade Andina.- É o órgão executivo da Comunidade Andina e outorga apoio técnico aos demais órgãos e instituições do SAl. É dirigida por um Secretário Geral e expressa-se mediante Resoluções. A sede da Secretaria Geral é a cidade de Lima, Peru.

- Tribunal de Justiça.- É o órgão jurisdicional da CAN, segue as normas do Tratado de sua criação, seus protocolos modificativos e o Acordo de Cartagena. A sede do Tribunal Andino de Justiça é a cidade de Quito, Equador.

- Parlamento Andino.- É o órgão de deliberação do Sistema. É composto pelos representantes dos Congressos Nacionais. Sua sede é Bogotá, Colômbia.

- Conselho Consultivo Empresarial e o Conselho Consultivo de Trabalho.constituído por representantes dos setores empresariais e do trabalho, são órgãos consultivos que emitem opinião sobre suas áreas dentro do processo de integração.

- Corporação Andina de Fomento e Fundo Latino-americano de Reservas. são as instituições financeiras do sistema que têm como função impulsionar o processo de integração.

- Convênio Andrés Bello.- órgão que tem como funções preservar a identidade cultural, e desenvolver a educação, a ciência e a cultura.

- Convênio Hipólito Unanue.- órgão que tem como função melhorar a saúde.

- Convênio Simon Rodriguez.- É o órgão que tem como função adotar estratégias e planos de ação que conduzam ao melhoramento integral das condições de vida e de trabalho dos Países Membros."

\footnotetext{
${ }^{28}$ Comunidade Andina. http://www.comunidadandina.org
} 


\subsection{3.- INSTRUMENTOS ECONÔMICOS DA INTEGRAÇÃO ANDINA}

De acordo com a Comunidade Andina, seus principais instrumentos econômicos são: ${ }^{29}$

- Programa de liberação comercial;

- Tarifa externa comum e Sistema andino de parcelas de preços agropecuários;

- Cláusulas de salvaguarda;

- Normas da origem;

- Regime especial para Bolívia e Equador;

- Harmonização das políticas econômicas e coordenação dos planos de desenvolvimento;

- Normas de defesa da concorrência comercial;

- Programas de desenvolvimento industrial;

- Programas de desenvolvimento agropecuário;

- Integração física;

- Assuntos financeiros;

- Cooperação econômica e social.

\section{2.- ASPECTOS GERAIS DO MERCOSUL}

O Mercado Comum do Sul, denominado Mercosul, é um bloco econômico composto por quatro países - Argentina, Brasil, Paraguai e Uruguai - e que tem por objetivo acelerar seu desenvolvimento econômico e social.

De acordo com dados de sua página em internet, ${ }^{30}$ apresento os seguintes dados macroeconômicos: 


\section{DADOS MACROECONÔMICOS DO MERCOSUL}

\begin{tabular}{|l|c|c|}
\hline \multicolumn{1}{|c|}{ Área } & Em milhares de km² & Em \% \\
\hline Mercosul & 11.863 & 8,9 \\
\hline Mercosul, Bolívia & 13.719 & 10,3 \\
\hline População: 1999 & Em milhões & Em \% \\
\hline Mercosul & 213 & 3,56 \\
\hline Mercosul, Bolívia e Chile & 236 & 3,95 \\
\hline P.I.B. 1999 & Em bilhões de US\$ & Em \% \\
\hline Mercosul & $1.048,7$ & 3,59 \\
\hline Mercosul, Bolívia e Chile & $1.128,0$ & 3,86 \\
\hline
\end{tabular}

Fonte: http://www.mercosul.org

\begin{tabular}{|l|c|c|c|}
\hline \multicolumn{1}{|c|}{ Comércio 1999 } & $\begin{array}{c}\text { Em bilhões de } \\
\text { US\$ }\end{array}$ & Em \% & Em \% do P.I.B. \\
\hline Mercosul & 154,1 & 1,36 & 14,7 \\
\hline $\begin{array}{l}\text { Mercosul, Bolívia e } \\
\text { Chile }\end{array}$ & 187,7 & 1,65 & 16,6 \\
\hline
\end{tabular}

Fonte: http://www.mercosul.org

'Exportações (FOB) mais Importações (CIF) de bens/P.I.B.

\footnotetext{
${ }^{29}$ Comunidade Andina. http://www. comunidadandina.org/
} 
COMÉRCIO' - Relação Porcentual do Mercosul com:

\begin{tabular}{|c|c|c|c|c|c|}
\hline & $\mathbf{1 9 9 1}$ & $\mathbf{1 9 9 3}$ & $\mathbf{1 9 9 5}$ & $\mathbf{1 9 9 7}$ & $\mathbf{1 9 9 9}$ \\
\hline NAFTA & 6,22 & 6,88 & 8,04 & 8,55 & 6,18 \\
\hline U. Européia & 2,62 & 3,54 & 3,90 & 4,50 & 3,58 \\
\hline Asiáticos $^{2}$ & 13,46 & 13,23 & 13,19 & 15,27 & 14,34 \\
\hline Mundo & 1,14 & 1,36 & 1,44 & 1,67 & 1,36 \\
\hline
\end{tabular}

Notas:

${ }^{1}$ exportações FOB mais importações CIF de bens

${ }^{2}$ Asiáticos: Corea, Hong Kong, Malásia, Singapur e Tailândia

Fonte: Indicadores macroeconômicos do Mercosul, Sistema Integral de Informação ALADI, FMI - Direction of Trade Statistics citado por http://www.mercosul.org

COMÉRCIO' - Relação Porcentual do Mercosul, Bolívia e Chile com:

\begin{tabular}{|c|c|c|c|c|c|}
\hline & $\mathbf{1 9 9 1}$ & $\mathbf{1 9 9 3}$ & $\mathbf{1 9 9 5}$ & $\mathbf{1 9 9 7}$ & $\mathbf{1 9 9 9}$ \\
\hline NAFTA & 7,63 & 8,35 & 9,94 & 10,29 & 7,53 \\
\hline U. Européia & 3,21 & 4,30 & 4,83 & 5,43 & 4,36 \\
\hline Asiáticos $^{2}$ & 16,52 & 16,06 & 16,31 & 18,38 & 17,47 \\
\hline Mundo & 1,40 & 1,65 & 1,78 & 2,01 & 1,65 \\
\hline
\end{tabular}

${ }^{1}$ exportações FOB mais importações CIF de bens

${ }^{2}$ Asiáticos: Corea, Hong Kong, Malásia, Singapur e Tailândia 
Fonte: Indicadores macroeconômicos do Mercosul, Sistema Integral de Informação ALADI, FMI - Direction of Trade Statistics citado por www.mercosul.org

\section{COMÉRCIO INTRABLOCOS ECONÔMICOS}

a) IMPORTAÇÕES: EM PORCENTAGENS

\begin{tabular}{|c|c|c|c|c|c|}
\hline & $\mathbf{1 9 9 1}$ & $\mathbf{1 9 9 3}$ & $\mathbf{1 9 9 5}$ & $\mathbf{1 9 9 7}$ & $\mathbf{1 9 9 9}$ \\
\hline MERCosUL & 16,0 & 20,3 & 18,4 & 20,7 & 19,2 \\
\hline NAFTA & 36,0 & 37,0 & 38,3 & 41,8 & 38,3 \\
\hline U. Européia & 67,0 & 60,8 & 61,0 & 58,6 & 60,4 \\
\hline Asiáticos $^{2}$ & 15,3 & 15,6 & 15,8 & 16,0 & 18,1 \\
\hline
\end{tabular}

${ }^{1}$ Como porcentagem no total do bloco

${ }^{2}$ Asiáticos: Corea, Hong Kong, Malásia, Singapur e Tailândia

Fonte: Indicadores Macroeconômicos do Mercosul, FMI - Direction of Trade

Statistics citado por http://www.mercosul.org

b) EXPORTAÇÕES: EM PORCENTAGENS

\begin{tabular}{|c|c|c|c|c|c|}
\hline & 1991 & 1993 & 1995 & 1997 & 1999 \\
\hline MERCOSUL & 11,1 & 18,6 & 20,5 & 24,3 & 20,4 \\
\hline NAFTA & 42,2 & 45,6 & 46,3 & 51,3 & 52,7 \\
\hline U. Européia & 66,8 & 63,9 & 64,4 & 60,3 & 60,6 \\
\hline
\end{tabular}




\begin{tabular}{|l|l|l|l|l|l|}
\hline Asiáticos $^{2}$ & 17,5 & 17,9 & 20,6 & 20,1 & 16,8 \\
\hline
\end{tabular}

${ }^{1}$ Como porcentagem no total do bloco

${ }^{2}$ Asiáticos: Corea, Hong Kong, Malásia, Singapur e Tailândia

Fonte: Indicadores Macroeconômicos do Mercosul, FMI - Direction of Trade

Statistics citado por http://www.mercosul.org 


\subsection{1.- PAÍSES INTEGRANTES DO MERCOSUL}

PAÍSES DO MERCOSUL

(Dados de 1999)

\begin{tabular}{|c|c|c|c|c|c|c|c|c|}
\hline & \multicolumn{2}{|c|}{ ARGENTINA $^{1}$} & \multicolumn{2}{|c|}{ BRASIL ${ }^{2}$} & \multicolumn{2}{|l|}{ PARAGUAI $^{3}$} & \multicolumn{2}{|c|}{ URUGUAI $^{4}$} \\
\hline Nome oficial: & República Argentina & & $\begin{array}{l}\text { República Federati } \\
\text { do Brasil }\end{array}$ & va & República do Paragu & uai & \multicolumn{2}{|c|}{$\begin{array}{l}\text { República Oriental do } \\
\text { Uruquai }\end{array}$} \\
\hline Língua oficial: & Espanhol & & Português & & Espanhol & & Espanhol & \\
\hline Capital: & Buenos Aires & & Brasilia & & Assunção & & Montevideo & \\
\hline Presidente: & Fernando de la Rúa & & Fernando Henrique & Cardoso & Luis González Macch & & Jorge Batlle & \\
\hline Habitantes (milhões) & 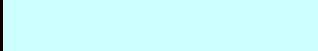 & 36,6 & & 163,7 & & 5,4 & & 3,3 \\
\hline P.I.B (bilhões de dólares) & & 281,9 & & 761,0 & & 8,5 & & 20,1 \\
\hline Variação do P.I.B. real & & $-3,0 \%$ & & $0,8 \%$ & & $-2,4 \%$ & & $-3,40 \%$ \\
\hline Produto Per cápita (dólares) & & 7.708 & & 4.650 & & 1.579 & & 6.098 \\
\hline Índice de Preços ao consumidor & & $-1,5 \%$ & & $8,9 \%$ & & $12,4 \%$ & & $5,3 \%$ \\
\hline Índice de Preços por Atacado & & $1,0 \%$ & & $28,7 \%$ & & $2,1 \%$ & & $0,1 \%$ \\
\hline Tipo de Câmbio (Dez. 99) & (pesos por US\$) & 1,0 & (reais por US\$) & 1,91 & (guaraníes porUS\$) & 3.320 & (pesos por US\$) & 11,59 \\
\hline Export.FOB ao mundo (bilhões US\$) & & 23,3 & & 48,0 & & 0,7 & & 2,2 \\
\hline Import. do mundo (bilhões US\$) & (C.I.F.) & 25,5 & (F.O.B.) & 49,2 & (C.I.F.) & 1,9 & (C.I.F.) & 3,4 \\
\hline Reservas Internac.líq. (bilhões US\$) & & 26,4 & & 36,3 & & 1,0 & & 2,4 \\
\hline Dívida externa (bilhões US\$) & & 119,2 & & 76,9 & & 2,1 & & 5,5 \\
\hline
\end{tabular}

Fonte:

${ }^{1}$ BCRA, Ministério de Economia e INDEC apud www.mercosur.com/es/info/argentina.jsp

${ }^{2}$ Banco Central do Brasil, IBGE, Macrometrica e FMI apud www.mercosur.com/es/info/brasil.jsp

${ }^{3}$ Banco Central do Paraguai, Ministério de Finanças, FMI, BID e CEPAL apud www.mercosur.com/es/info/paraguay.jsp

${ }^{4}$ Banco Central do Uruguai, Ministério de Finanças, FMI, BID e CEPAL apud www.mercosur.com/es/info/uruguay.jsp 


\subsection{2.- OBJETIVOS DO MERCOSUL}

O Mercosul ainda não é um mercado comum, organização que, além de mercadorias e serviços, permite a livre circulação de cidadãos e investimentos.

O Mercosul pretende ser, por enquanto, uma zona de integração aduaneira, pela qual os quatro países membros circulam produtos sem cobrar mutuamente direitos alfandegários e mantêm, com relação a terceiros, as mesmas taxas aduaneiras.

A TEC (Tarifa Externa Comum) abrange $85 \%$ dos produtos negociados. Os 15\% restantes terão um prazo maior de adaptação (variando de 2001 a 2006).

De acordo com dados de Lima: ${ }^{31}$

"O Tratado de Assunção, o Mercosul será, quando plenamente constituído, um mercado comum entre Argentina, Brasil, Paraguai e Uruguai, com a livre circulação de bens, serviços e fatores produtivos, formado através:

a) de um programa de liberalização comercial, baseado em reduções tarifárias progressivas, lineares e automáticas, e na eliminação de restrições comerciais de qualquer natureza, com a zeragem das tarifas para o comércio intraregional;

\footnotetext{
${ }^{31}$ Lima Régo, Elba. Op. Citada. p. 171 - 172.
} 
b) da coordenação gradual das políticas macroeconômicas e setoriais;

c) da adoção de acordos setoriais;

d) da fixação, durante a constituição do mercado comum, de um regime geral de origem, de cláusulas comuns de salvaguarda e de um sistema provisório de solução de controvérsias;

e) e da harmonização legislativa em áreas pertinentes."

\subsection{3. - ESTRUTURA INSTITUCIONAL DO MERCOSUL}

De acordo com dados do PROCERGS ${ }^{32}$, a nova estrutura institucional, definida no Protocolo de Ouro Preto, conta com os seguintes órgãos:

- "Conselho do Mercado Comum (CMC), definido como o órgão superior de encaminhamento político do processo de integração, sendo formado pelos ministros das Relações Exteriores e da Economia dos quatro países.

- Grupo Mercado Comum (GMC), que recebeu a função de órgão executivo, sendo composto por quatro representantes de cada país, vinculados aos bancos centrais e ministérios das Relações Exteriores e da Economia. O GMC ficou responsável pela adoção das medidas necessárias à implementação das decisões do Conselho, pela cooperação econômica setorial e macroeconômica e pelo estabelecimento do cronograma de atividades.

- Comissões do Mercosul:

- Comissão de Comércio: terá a função de fiscalizar a aplicação da Tarifa Externa Comum (TEC).

- Comissão Parlamentar Conjunta: composta por parlamentares dos quatro países. Terá caráter consultivo, formulando recomendações e propostas ao Conselho do Mercado Comum através do Grupo Mercado Comum.

- Comissão Consultiva Econômica e Social: é a instância de representação do setor privado no Mercosul.

- Secretaria Administrativa do Mercosul

Em fevereiro de 1995, foi aprovada a criação de Comitês Técnicos, que terão as funções de desenvolver assessoramento técnico.

Os Comitês serão integrados pelos membros designados por cada Estado parte. Foram constituídos comitês de Tarifas, Nomenclaturas e Classificação de Mercadorias; Assuntos Aduaneiros; Normas e Disciplinas Comerciais; Políticas Públicas que distorcem a competitividade; Defesa da Competência;

\footnotetext{
${ }^{32}$ PROCERGS Cia de Processamento de Dados. Antecedentes do Mercosul. Rio Grande do Sul, 1995.
} 
Práticas Desleais e Salvaguardas; Defesa do Consumidor; Restrições Não Tarifárias; Setor Automotriz e Setor Têxtil. Os Subgrupos de Trabalho, compostos por técnicos representantes dos países do Mercosul, em 1995, ajustaram-se à nova realidade, tendo a seguinte composição:

- Subgrupo 01 - Comunicações

- Subgrupo 02 - Mineração

- Subgrupo 03 -Regulamentos Técnicos

- Subgrupo 04 - Assuntos Financeiros

- Subgrupo 05 - Transportes e Infra-estrutura

- Subgrupo 06 - Meio Ambiente

- Subgrupo 07 - Indústria

- Subgrupo 08 - Agrícola

- Subgrupo 09 - Política energética

- Subgrupo 10 - Assuntos trabalhistas, emprego e seguridade social." 33

No subgrupo 04 Assuntos Financeiros está incluído o GIMCEA, Grupo de Integração do Mercosul, de Contabilidade, Economia e Administração; este grupo reúne os conselhos profissionais e organismos dos países membros do Mercosul.

As atividades do GIMCEA estão encaminhadas para conseguir a integração da região através da análise, comparação e harmonização das normas do exercício profissional e do assesoramento dos governos dos países membros do Mercosul.

\section{3.- RELAÇÃO MERCOSUL E COMUNIDADE ANDINA}

\footnotetext{
${ }^{33}$ PROCERGS. Op. Citada. p. 4.
} 
O Acordo Marco pela criação da Região de Livre Comércio entre a Comunidade Andina e o Mercosul foi assinado em 16 de abril de 1998, em Buenos Aires, Argentina.

Comunidade Andina (CAN): Bolívia, Colômbia, Equador, Peru e Venezuela. Mercado Comum do Sul (MERCOSUL): Argentina, Brasil, Paraguai e Uruguai. Este acordo vai beneficiar uma região de 300 milhões de habitantes.

\subsection{1.- PRINCÍPIOS BÁSICOS DO ACORDO:}

Estes princípios estão expressos na página da internet do Sistema de informação do Comércio exterior: ${ }^{34}$

"Que é necessário fortalecer e aprofundar o processo de integração da América Latina para atingir os objetivos previstos no Tratado de Montevidéu de 1980, mediante a celebração de acordos abertos à participação dos demais Países Membros da Associação Latino-americana de Integração (ALADI), que possam permitir a conformação de um espaço econômico amplo.

A integração econômica regional é um dos instrumentos essenciais para que os países de América Latina possam avançar no seu desenvolvimento econômico e social, assegurando melhor qualidade de vida para seus povos.

A conformação de áreas de livre comércio na América Latina constitui um elemento relevante para aproximar os blocos de integração existentes; ademais, é uma etapa fundamental para o processo de integração e o estabelecimento de uma área de livre comércio do hemisfério.

Uma contribuição à expansão do comércio mundial e para o eficiente funcionamento dos mercados, oferecendo regras claras aos agentes econômicos para o desenvolvimento do comércio de bens e serviços, assim como dos investimentos recíprocos entre a Comunidade Andina e o Mercosul."

Este processo de integração foi iniciado, segundo dados de $\operatorname{Lima}^{35}$, quando alguns países sul-americanos como Argentina, Brasil, Chile, Paraguai, Peru e 
Uruguai, criaram a Associação Latino-Americana de Livre Comércio (ALALC), em 1960, visando a formação de uma região de livre comércio e a constituição de um mercado comum em um prazo de 12 anos. Em 1980, o fracasso da ALALC levou à criação da Associação Latino-Americana de Integração (ALADI), com o objetivo de formar uma área de preferência tarifária composta por uma preferência tarifária regional, por acordos regionais e por acordos de alcance parcial travados entre dois ou mais países.

\subsection{2.- OBJETIVOS DO ACORDO}

Os objetivos deste acordo foram estabelecidos em Buenos Aires, em 1998, e são os seguintes: $:^{36}$ :

- "Estabelecer o marco jurídico e institucional de cooperação e integração econômica e física, que contribua para a criação de um espaço econômico grande que possa facilitar a livre circulação de bens e serviços e a plena utilização dos fatores produtivos, em condições de competência e de igualdade entre as Partes.

- Formar uma área de livre comércio mediante a expansão e diversificação do comércio e a eliminação de restrições que afetem o comércio recíproco.

- Promover o desenvolvimento e a utilização da infra-estrutura física, com especial ênfase no estabelecimento de corredores de integração, que permita a diminuição de despesas e a geração de vantagens competitivas no comércio regional e com países terceiros, fora da região.

- Estabelecer um marco normativo para promover e impulsionar os investimentos recíprocos entre os agentes econômicos das Partes.

- Promover a cooperação econômica, energética, científica e tecnológica.

- Promover consultas, quando necessário, nas negociações comerciais com países terceiros e blocos de países fora da região."

\footnotetext{
${ }^{34}$ Sistema de informação do Comércio exterior. http://www.sice.oas.org/trade

${ }^{35}$ Lima Régo, Elba. Op. citada p. 169.

${ }^{36}$ Sistema de informação sobre comércio exterior. http://www.sice.oas.org/trade
} 


\subsection{3.- ESTABELECIMENTO DA ÁREA DE LIVRE COMÉRCIO}

De acordo com dados da página de internet da CAN, ${ }^{37}$ o estabelecimento da área de livre comércio entre o Mercosul e a CAN passou por diversos momentos:

- Este acordo para a criação de uma Área de Livre Comércio entre a Comunidade Andina e o Mercosul, assinado em 16 de abril de 1998, tinha estabelecido duas etapas: na primeira etapa, até 30 de setembro de 1998, negociariam um Acordo de preferências de tarifas; na segunda etapa, de $1^{0}$ de outubro a 31 de dezembro de 1999, se negociaria o Acordo de Livre Comércio, que entraria em vigência em $1^{0}$ de janeiro de 2000.

- Depois aconteceram outras Reuniões de Negociação. Na quarta Reunião de Negociação, celebrada em Lima, em setembro de 1998, foi acordado prorrogar as negociações até 31 de março de 1999. Prorrogando também até essa data a vigência dos Acordos

\footnotetext{
${ }^{37}$ http://www.comunidadandina.org
} 
de Alcance Parcial celebrados no marco da ALADI, que formam o "patrimônio histórico".

- Até março de 1999 continuam se realizando negociações entre os dois blocos.

- Em 28 de março de 1999, o Brasil anuncia sua decisão de negociar unilateralmente o Acordo de Preferências de Tarifas com a CAN.

- Em 12 de abril de 1999, a CAN anuncia a abertura de dois processos de negociações, um com o Brasil e o outro com os demais países do Mercosul.

- Depois de várias negociações, em agosto de 1999, Brasil e a CAN assinaram um Acordo de Complementação Econômica como um primeiro passo até a criação da Zona de Livre Comércio.

- Igualmente aconteceram várias reuniões de negociação da CAN com a Argentina com o mesmo objetivo, assinando-se um Acordo similar em 29 de junho de 2000.

- Os outros países do Mercosul: Uruguai e Paraguai estão se preparando para negociar com a CAN. 
- Na reunião dos Presidentes da América do Sul no ano 2000, foi marcado o mês de janeiro de 2002 como o prazo para o estabelecimento do Livre Comércio entre os dois Blocos.

\section{Dados Macroeconômicos de América do Sul}

De acordo com dados da Comunidade Andina, apresento o seguinte quadro comparativo em relação ao P.I.B. per cápita mensurado em P.I.B. de paridade do poder de compra.

Nos últimos anos o P.I.B. per cápita da Comunidade Andina teve uma diminuição, chegando a US\$4.710.

O Mercosul teve um incremento de $4 \%$ em relação a 1998. (US\$ 6.841) 
Quadro comparativo do crescimento do P.I.B. na América do Sul e o Caribe 
Fonte: Banco Mundial, http://www.worldbank.org citado por

http://www.comunidadandina.org.

\section{3.- MARCO CONCEI TUAL DOS CI NCO PAÍ SES}

Nos países da América do Sul, não existe ainda um marco conceitual comum necessário para a obtenção da harmonização da contabilidade, não 
obstante existem muitas semelhanças e algumas diferenças entre eles, como poderá observar-se depois.

Anteriormente, o marco conceitual foi chamado de declarações de princípios, mas agora esse marco é mais amplo e sua importância é reconhecida.

Pereda define o marco conceitual como ${ }^{38}$ "uma interpretação da teoria geral da Contabilidade, mediante a qual estabelecem-se, através de um processo lógico dedutivo, os fundamentos teóricos nos quais é apoiada a informação financeira."

Romero dá uma definição de Teoria de maneira geral: ${ }^{39}$

“Uma teoria é um conjunto de enunciados com proposições verídicas que explicitam constantes de mudança da realidade (Leis, Axiomas ou Princípios) estruturados de maneira que permitam descrever, explicar ou predizer partes ou elementos relevantes do campo de estudo ou especialidade de uma ciência."

Pode-se deduzir que as leis, axiomas e princípios formam parte da Teoria.

De acordo com Romero, a definição de Doutrina é a seguinte: ${ }^{40}$

“Uma Doutrina, é uma aceitação que vai além do simples antecedente jurídico, é um conjunto de enunciados proposicionais que estruturam, como elementos indispensáveis a delineamentos teóricos, em maior ou menor medida, com delineamentos ideológicos; com o propósito de dispor ou ordenar, como deve ser algo, em termos normalizadores, ou seja através de normas, que devem ser cumpridas.

\footnotetext{
${ }^{38}$ PEREDA, Jorge Tua. Op. Citada. InterAmérica. Ano III, N. 8, Janeiro - Junho, 2000. pág. 75.

${ }^{39}$ ROMERO, Alejandro Caballero. Los principios y sus relaciones con las leyes, axiomas, teorías, doctrinas y normas. http://www.ccpl.org.pe. Perú, 1999.

${ }^{40}$ ROMERO, Alejandro Caballero. Op. citada. http://www.ccpl.org.pe. Perú, 1999.
} 
Uma Doutrina, tem maior base teórico - científica, na medida em que é maior a proporção de delineamentos teóricos que contém ou integra; e, os Princípios são parte importante dela.

Mas a diferença fundamental entre a Teoria e a Doutrina está em que esta última integra, além de delineamentos teóricos, delineamentos ideológicos."

Segundo esta definição, a Doutrina tem como principal expressão as normas.

A teoria geral da contabilidade é, de acordo com Pereda: "o conjunto de elementos e conceitos comuns que estão presentes em todos os sistemas contábeis". 41

Esses elementos comuns são: "captação, medida, avaliação, representação e comunicação.”

A importância do Marco conceitual é salientada por Pereda, que o considera como uma referência teórica e também como um aglutinante sociológico que legitima os pronunciamentos e regras posteriores.

Segundo o mesmo autor, a utilidade do Marco Conceitual pode resumir-se nos seguintes itens: ${ }^{42}$

- "Servir de guia para o estabelecimento de normas contábeis.

- Orientar os usuários na aplicação dessas normas.

- Constituir-se como meio de referência para a resolução de problemas específicos na ausência de normas concretas.

- Fixar os limites de discrição na confecção das demonstrações financeiras.

\footnotetext{
${ }^{41}$ PEREDA, Jorge Tua. Op. Citada. InterAmérica. Ano III, N. 8, Janeiro - Junho, 2000. pág. 70

${ }^{42}$ PEREDA, Jorge Tua. Op. Citada. InterAmérica. Ano III, N. 8, Janeiro - Junho, 2000. pág. 76.
} 
- Aumentar o conhecimento e confiança dos usuários nas demonstrações financeiras.

- Potenciar sua comparabilidade."

De acordo com o Projeto TE $23:^{43}$

"As normas contábeis específicas devem ser precedidas por um marco conceitual que as justifique".

"Deve existir separação na teoria contábil entre aquela que é lógica, justa e harmoniosa (teoria contábil doutrinária expressa pelas Correntes de opiniões) e a teoria contábil normativa, que pode ser arbitrária, política e oportunista".

"Quando se fala de marco conceitual contábil, temos claro que estamos nos referindo à necessidade de obter informes financeiros (demonstrações contábeis) destinados a terceiros".

O Marco conceitual definido no IASC é diferente do Modelo contábil utilizado em outros países.

\section{“UM MARCO CONCEITUAL CONTÁBIL E UM MODELO CONTÁBIL}

O Marco conceitual constitui a teoria normativa contábil e está integrado por um conjunto de princípios "convencionais" que orientam a emissão de normas futuras. O marco conceitual pode incluir princípios sobre:

- Definição de contabilidade (poderia estar incluída nos objetivos das demonstrações contábeis)

- Objetivos das demonstrações contábeis

- Qualidades ou requisitos da informação contábil

- Modelo contábil

O Modelo contábil é uma enumeração de variáveis, uma seleção que compreende uma idéia, um desejo ou uma expectativa, escolhidas pelo "normatizador" segundo seu critério político de oportunidade.",44

O marco conceitual para a preparação e apresentação das demonstrações

financeiras do IASC, segundo este Projeto TE 23, é o seguinte: ${ }^{45}$

\footnotetext{
${ }^{43}$ UNIVERSIDADE DE BUENOS AIRES .Op. citada. Outubro de 2000. Pág. 1 e 2.
} 
"O marco conceitual abrange os seguintes aspectos:

- Objetivos das demonstrações financeiras: Prestar informação sobre a situação financeira, atividade e fluxos de fundos da empresa. Espera-se que tal informação seja útil para os usuários na tomada de suas decisões econômicas. As hipóteses fundamentais são o princípio de Realização e a Empresa em movimento.

- Características qualitativas que determinam a utilidade da informação das demonstrações financeiras: compreensibilidade, relevância, confiabilidade, representação fiel, realidade econômica, neutralidade, prudência, integridade comparabilidade, oportunidade, equilíbrio entre custo e benefício, equilíbrio entre as características qualitativas e apresentação veraz da informação financeira.

- Definição, reconhecimento e mensuração dos elementos que constituem as demonstrações financeiras:

- Elementos: ativos, passivos, capital, receitas e despesas.

- Reconhecimento e mensuração: uma conta que reúna a definição de um elemento reconhece-se se é provável que qualquer benefício econômico futuro associado com a conta em particular vai fluir à empresa ou da empresa, e se a conta tem um valor que pode ser medido de maneira confiável.

- Capital e manutenção do capital: pode-se escolher entre capital financeiro ou capital físico. A seleção deve estar baseada nas necessidades dos usuários das demonstrações financeiras".

As características qualitativas a que se refere este Projeto são os Princípios ou Hipóteses fundamentais do Sistema Contábil que servem de apoio à Contabilidade, e são somente uma parte da teoria geral da Contabilidade.

Segundo Pereda, nas estratégias no confronto com a harmonização existem vários desafios para o profissional contábil, destacando-se entre eles dois: ${ }^{46}$

"Elaborar e compartilhar uma teoria geral da Contabilidade."

\footnotetext{
${ }^{44}$ UNIVERSIDADE DE BUENOS AIRES .Op. citada. Outubro de 2000. Pág. 22.

${ }^{45}$ UNIVERSIDADE DE BUENOS AIRES. Op. citada. Outubro de 2000. Pág. 14.

${ }^{46}$ PEREDA, Jorge Tua. Op. Citada. InterAmérica. Ano III, N. 8, Janeiro - Junho, 2000. pág. 70.
} 
Outro dos desafios desse autor é: "Pesquisar e chegar a um acordo sobre a definição e significado das hipóteses fundamentais de nossos sistemas contábeis, assim como da melhor forma de aplicá-las para garantir sua utilidade."

\author{
Segundo Romero, a definição de Princípio é: ${ }^{47}$
}

"Um princípio é um enunciado com proposição verídica que explicita uma constante de mudança da realidade; que antes foi Lei ou Axioma, o qual quando for utilizado no início de um aplicativo teórico vai denominar-se Princípio.

A diferença fundamental entre uma Lei e um Axioma é o mecanismo do pensamento lógico que os originou, à Lei a dedução e ao axioma a intuição.

Um Princípio se diferencia de ambos porque é um deles, mas está sendo utilizado no início de um aplicativo teórico.

Na prática, pode-se comprovar que as Leis e Axiomas são usadas em livros sobre ciências puras ou teóricas; e, os Princípios, em livros sobre ciências aplicadas. A Administração, a Contabilidade, a Construção naval, etc., que são ciências aplicadas, utilizam Princípios."

Pereda faz três comentários em relação às hipóteses fundamentais do sistema ou Princípios. ${ }^{48}$

- "Os princípios contábeis não são a teoria geral da Contabilidade. São simplesmente um elo dentro de um sistema contábil. Os princípios são deduzidos, verificados e, se fosse necessário, rejeitados, de acordo com sua concordância com os passos prévios do processo lógico - dedutivo: cenário, objetivos, características e requisitos do sistema contábil.

- Os princípios contábeis existentes em um sistema (exemplo, a prudência na Contabilidade financeira) não podem estar presentes em outros (exemplo, na Contabilidade da balança de pagamentos).

- Uma regra não é facilmente transferível de um país a outro; é necessário sua verificação com o cenário e com os objetivos, características e requisistos do sistema contábil onde vai ser aplicada."

\footnotetext{
${ }^{47}$ ROMERO, Alejandro Caballero. Op. citada. www.ccpl.org.pe. Perú, 1999.

${ }^{48}$ PEREDA, Jorge Tua. Op. Citada. InterAmérica. Ano III, N. 8, Janeiro - Junho, 2000. pág. 74
} 
O processo lógico - dedutivo a que faz referência Pereda, refere-se à elaboração de um marco conceitual compartilhado necessário para a harmonização contábil.

Nos seguintes quadros apresentam-se os marcos conceituais dos cinco Países. 
QUADROS DOS MARCOS CONCEITUAIS DOS CINCO PAISES

\begin{tabular}{|c|c|c|c|c|c|}
\hline & ARGENTINA & BRASIL & COLÓMBIA & PERU & VENEZUELA \\
\hline $\begin{array}{l}\text { Definição de } \\
\text { Contabilidade }\end{array}$ & \begin{tabular}{|l|}
$R T n^{0} 10^{1}$ \\
"A contabilidade é uma \\
disciplina técnica \\
consistente num sistema de \\
informação destinado a \\
constituir uma base \\
importante para a tomada de \\
decisões e o controle da \\
gestão, aspectos onde \\
resulta relevante o conceito \\
de receita ou, em termos \\
mais amplos, de resultados."
\end{tabular} & $\begin{array}{l}\text { Res. CFC N }{ }^{0} 774 \text { de } 1994 \\
\text { "A contabilidade possui } \\
\text { objeto próprio- o Patrimô- } \\
\text { nio das Entidades- e con- } \\
\text { siste em conhecimentos } \\
\text { obtidos por metodologia } \\
\text { racional, com as condi- } \\
\text { ções de generalidade, cer- } \\
\text { teza e busca das causas, } \\
\text { em nível qualitativo seme- } \\
\text { Ihante às demais ciências } \\
\text { sociais." ¿2 }\end{array}$ & $\begin{array}{l}\text { Decreto } 2649 \text { de } 29 / 12 / 93^{3} \\
\text { "Conhecer e demonstrar } \\
\text { os recursos controlados } \\
\text { por uma entidade econômi- } \\
\text { ca, as obrigações de } \\
\text { transferir recursos a outras } \\
\text { entidades, as mudanças } \\
\text { desses recursos e o resul- } \\
\text { tado obtido no período." } \\
\text { "Apoiar no planejamento, } \\
\text { organização e gestão dos } \\
\text { negócios." }\end{array}$ & $\begin{array}{l}\text { Não foi encontrada uma } \\
\text { definição de Contabilida- } \\
\text { de na sua legislação. } \\
\text { Mas é considerada como } \\
\text { ciência social em suas } \\
\text { universidades. }\end{array}$ & $\begin{array}{l}\text { DPC } 0^{4} \\
\text { "A contabilidade deve } \\
\text { ser considerada uma } \\
\text { atividade de serviço, um } \\
\text { sistema de informação } \\
\text { e uma disciplina } \\
\text { descritiva e analítica". }\end{array}$ \\
\hline $\begin{array}{l}\text { Objetivo das } \\
\text { Demonstrações } \\
\text { Contábeis ou } \\
\text { Financeiras }\end{array}$ & \begin{tabular}{|l|} 
Projeto RT $\mathrm{n}^{0} 16^{5}$ \\
"O objetivo das \\
Demonstrações \\
Contábeis é prover \\
informação sobre o \\
patrimônio da entidade \\
numa data determinada e \\
sua evolução econômica e \\
financeira para facilitar \\
a tomada de decisões \\
econômicas".
\end{tabular} & $\begin{array}{l}\text { "O objetivo científico da } \\
\text { Contabilidade manifesta-se } \\
\text { na correta apresentação } \\
\text { do Patrimônio e na apreen- } \\
\text { são e análise das causas } \\
\text { das suas mutações. Busca } \\
\text { prover os usuários com in- } \\
\text { formações sobre aspectos } \\
\text { de natureza econômica, fi- } \\
\text { nanceira e física do Patri- } \\
\text { mônio da Entidade e suas } \\
\text { mutações, o que com- } \\
\text { preende registros, demons- } \\
\text { trações, análises, e outros" }\end{array}$ & $\begin{array}{l}\text { Decreto } 2649 \text { de } 29 / 12 / 93 \\
\text { "As demonstrações finan- } \\
\text { ceiras são o meio principal } \\
\text { para proporcionar informa- } \\
\text { ção contábil àqueles que } \\
\text { não têm acesso aos regis- } \\
\text { tros de uma entidade eco- } \\
\text { nômica." } \\
\text { "Demonstram numa data } \\
\text { a recompilação, classifica- } \\
\text { ção e resumo final dos } \\
\text { dados contábeis." }\end{array}$ & \begin{tabular}{|l|} 
Adotou normas do IASC \\
"O objetivo é prover \\
informação sobre a \\
posição financeira, o \\
desempenho e fluxo de \\
fundos de uma empresa \\
que resulte útil para a \\
tomada de decisões \\
econômicas para uma \\
grande variedade de \\
usuários".
\end{tabular} & $\begin{array}{l}\text { Interpretação da DPC } 0^{9} \\
\text { "A contabilidade é } \\
\text { denominada com } \\
\text { freqüência a linguagem } \\
\text { dos negócios, porque é } \\
\text { a língua que usam os } \\
\text { empresários para poder } \\
\text { mensurar e apresentar } \\
\text { os resultados obtidos } \\
\text { no exercício econômico, } \\
\text { a situação financeira das } \\
\text { empresas, as mudanças } \\
\text { na posição financeira } \\
\text { e/ou o fluxo de caixa". }\end{array}$ \\
\hline
\end{tabular}

Fonte ${ }^{[1]}{ }^{[5]}$ Universidad de Buenos Aires. Determinación de las "bases teóricas" para la armonización de normas contables en el Mercosur. 1998

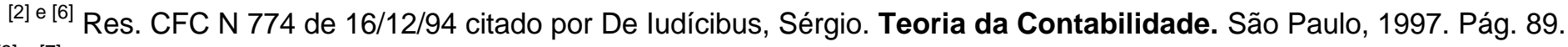

${ }^{[3]}$ e [7] Decreto 2649 de 29/12/93 citado pelo Instituto de Contadores Públicos da Colômbia e http://www.incp.org.co

${ }^{[4]}$ e [9] DPC 0 citado por Carpio, Fernando Catacora. PCGA en Venezuela. Caracas, 1999.

${ }^{[8]}$ IASC citado por Universidade de Buenos Aires. Op. citada. p. 31 e 32 


\begin{tabular}{|c|c|c|c|c|}
\hline & \multicolumn{4}{|c|}{ ELEMENTOS DAS DEMONSTRAÇÕES CONTÁBEIS } \\
\hline ARGENTINA & BRASIL & COLÔMBIA & PERU & VENEZUELA \\
\hline $\begin{array}{l}\text { Projeto RT } 16 \\
\text { "Situação Patrimonial } \\
\text { Ativos } \\
\text { Passivos } \\
\text { Patrimônio Líquido } \\
\text { Participações de acio- } \\
\text { nistas não controladores } \\
\text { nos patrimônios de em- } \\
\text { presas controladas } \\
\text { Evolução Patrimonial } \\
\text { Operações com os } \\
\text { proprietários } \\
\text { Resultado do período: } \\
\text { Receitas, despesas, } \\
\text { ganhos e perdas } \\
\text { Impostos que são apli- } \\
\text { cados a receitas finais } \\
\text { Participação de acionis- } \\
\text { não controladores sobre } \\
\text { resultados de empresas } \\
\text { controladas } \\
\text { Evolução Financeira } \\
\text { Caixa } \\
\text { Equivalentes de Caixa" }{ }^{1}\end{array}$ & $\begin{array}{l}\text { Conselho Federal de } \\
\text { Contabilidade } \\
\text { "NBC-T-3, NBC-T6, NBC-T8 } \\
\text { Balanço Patrimonial } \\
\text { Ativos } \\
\text { Passivos } \\
\text { Patrimônio Líquido } \\
\text { Demonstração do Resultado } \\
\text { Receitas, Despesas, Im- } \\
\text { postos, Ganhos e Perdas } \\
\text { Demonstração das Mutações } \\
\text { do Patrimônio Líquido ou } \\
\text { Demonstração de Lucros ou } \\
\text { Prejuízos Acumulados } \\
\text { Demonstração das Origens e } \\
\text { Aplicações de Recursos } \\
\text { Notas Explicativas } \\
\text { Instrução CVM 64/87 } \\
\text { Demonstrações Financeiras } \\
\text { Consolidadas } \\
\text { Demonstrações Contábeis } \\
\text { Complementares em Moeda } \\
\text { de Capacidade Aquisitiva } \\
\text { constante". ² }\end{array}$ & $\begin{array}{l}\text { (D.R. 2649/93) } \\
\text { "Balanço Geral } \\
\text { Ativos } \\
\text { Passivos } \\
\text { Patrimônio Líquido } \\
\text { Demonstração de Resultados } \\
\text { Receitas, Despesas, Im- } \\
\text { postos, ganhos, perdas e } \\
\text { correção monetária. } \\
\text { Demonstração da Evolução do } \\
\text { Patrimônio Líquido } \\
\text { Demonstração de Mudanças } \\
\text { na Situação Financeira } \\
\text { Demonstração dos Fluxos de } \\
\text { de Caixa } \\
\text { Caixa } \\
\text { Equivalentes de Caixa". }{ }^{3}\end{array}$ & $\begin{array}{l}\text { (Conasev N 006/84-EFC 94-10) } \\
\text { "Balanço Geral ou Demonstração } \\
\text { da Situação Patrimonial } \\
\text { Ativos } \\
\text { Passivos } \\
\text { Patrimônio Líquido } \\
\text { Demonstração de Resultados } \\
\text { Receitas, Despesas, Im- } \\
\text { postos, ganhos, perdas e } \\
\text { correção monetária. } \\
\text { Demonstração da Evolução do } \\
\text { Patrimônio Líquido } \\
\text { Demonstração dos Fluxos de } \\
\text { de Caixa } \\
\text { Caixa } \\
\text { Equivalentes de Caixa ". } \\
\text { Notas às Demonstrações } \\
\text { Financeiras." } 4\end{array}$ & $\begin{array}{l}\text { DPC - 0 } \\
\text { "Balanço Geral } \\
\text { Ativos } \\
\text { Passivos } \\
\text { Patrimônio Líquido } \\
\text { Demonstração de Resultados } \\
\text { Receitas, Despesas, Im- } \\
\text { postos, ganhos, perdas e } \\
\text { correção monetária. } \\
\text { Demonstração de custo de } \\
\text { vendas } \\
\text { Demonstração de custo de } \\
\text { produção e vendas } \\
\text { (não obrigatório) } \\
\text { Demonstração das Mudanças } \\
\text { no Patrimônio Líquido } \\
\text { Demonstração dos Fluxos } \\
\text { de Caixa } \\
\text { Caixa } \\
\text { Equivalentes de Caixa } \\
\text { Notas às Demonstrações } \\
\text { Financeiras". }{ }^{\text {F }}\end{array}$ \\
\hline
\end{tabular}

Fonte:

${ }^{1}$ Projeto RT 16 citado por Universidade de Buenos Aires. Op. Citada. Pág. 32 e 33 e http://www.facpe.org.ar

${ }^{2}$ IOB Temática Contábil e Balanços. Demonstrações financeiras obrigatórias. Ano XXXIV - Janeiro de 2000 - N 3. p. 9 -11

${ }^{3}$ http://www.incp.org.co

${ }^{4}$ CONASEV Reglamento para la preparación de información financiera e información auditada. Lima, 1998.

${ }^{5}$ DPC 0 citado por Carpio, Fernando Catacora. Op. Citada. Caracas, 1999. 


\begin{tabular}{|c|c|c|c|c|}
\hline & BRASIL & BIA & PERU & ELA \\
\hline $\begin{array}{l}\text { Requisitos da Informação. } \\
\text { Contábil } \\
\text { R.T. n } 16 \text { de } 2000 \text { - } \\
\text { FACPCE } \\
\text { Pertinência } \\
\text { Confiabilidade } \\
\text { Aproximação à realidade } \\
\text { Essencialidade } \\
\text { Neutralidade } \\
\text { Integridade } \\
\text { Verificabilidade } \\
\text { Sistematização } \\
\text { Comparabilidade } \\
\text { Clareza } \\
\text { Restrições: } \\
\text { Oportunidade } \\
\text { Equilíbrio entre Custos e } \\
\text { Benefícios } \\
\text { [http://www.facpce.org.ar\} }\end{array}$ & $\begin{array}{l}\text { Princípios Fundamentais de C. } \\
\text { Res.CFC n } 750 \text {, de 29-12-93 } \\
\text { 1) O Princípio da Entidade } \\
\text { 2) O Princípio da Continuidade } \\
\text { 3) O Princípio da Oportunidade } \\
\text { 4) O P. do registro pelo V. Origin. } \\
\text { 5) O P.da Atualização Monetária } \\
\text { 6) O Princípio da Competência } \\
\text { 7) O Princípio da Prudência } \\
\text { Princ. Fundam.CVM e IBRACoN } \\
\text { A. Os Postulados } \\
\text { A1. Da Entidade } \\
\text { A2. Da Continuidade } \\
\text { B. Os Princípios Propriam Ditos } \\
\text { B1. Do Custo como B.de Valor } \\
\text { B2. Do Denom. Comum Mon. } \\
\text { B3. Da Realização da Receita } \\
\text { B4. Do Confronto das Despe- } \\
\text { sas com as Receitas e } \\
\text { com os Períodos contábeis } \\
\text { C. As Convenções (Restrições) } \\
\text { C1. Da Objetividade } \\
\text { C2. Da Materialidade (Relev) } \\
\text { C3. Do Conservadorismo(Prud) } \\
\text { C4. Da Consistência (Uniform.) } \\
\text { [De ludícibus, Sérgio. Teoria } \\
\text { da Contabilidade. SP, 1997.] } \\
\text { Atributos: Tempestividade, Com- } \\
\text { pleteza, Confiabilidade, Compara- } \\
\text { bilidade, Compreensibilidade. } \\
\text { Res.CFC nº 785, de julho de 1995 } \\
\text { [ludícibus, Teoria da Contab. SP.] }\end{array}$ & $\begin{array}{l}\text { Normas Básicas } \\
\text { Decreto } 2649 \text { de 29/12/93 } \\
\text { 1) O Ente Econômico } \\
\text { 2) Continuidade } \\
\text { 3) Unidade de Mensuração } \\
\text { 4) Período Contábil } \\
\text { 5) Avaliação ou Mensuração } \\
\text { 6) Essência sobre Forma } \\
\text { 7) Realização } \\
\text { 8) Associação ou relação } \\
\text { de causalidade } \\
\text { 9) Manutenção do Patrimônio } \\
\text { 10) Revelação plena } \\
\text { 11) Materialidade } \\
\text { 12) Conservadorismo ou } \\
\text { Prudência } \\
\text { 13) Características e práticas } \\
\quad \text { de cada atividade } \\
\text { [http://www.incp.org.co\} } \\
\\
\text { Qualidades da Informação } \\
\text { contábil } \\
\text { Decreto } 2649 \text { de 29/12/93 } \\
\text { 1) Comparabilidade } \\
\text { 2) Compreensibilidade } \\
\text { 3) Utilidade } \\
\text { 4) Pertinência } \\
\text { 5) Confiabilidade } \\
\text { 6) Bases uniformes } \\
\text { [http://www.incp.org.co\} }\end{array}$ & $\begin{array}{l}\text { Princípios Gerais de } \\
\text { Contabilidade } \\
\text { R.C. } N^{0} 006-84-E F C / 94-10 \\
\text { R. C. } N^{0} 252-85-E F / 94-01 \\
\text { R. de CONT. N }{ }^{0} 005-94- \\
\text { EF/93-01 } \\
\text { 1) Equidade } \\
\text { 2) Partida Dobrada } \\
\text { 3) Entidade } \\
\text { 4) Bens Econômicos } \\
\text { 5) Denominador Comum } \\
\text { Monetário } \\
\text { 6) Empresa em Movimento } \\
\text { 7) Avaliação ao custo } \\
\text { 8) Período } \\
\text { 9) Competência } \\
\text { 10) Objetividade } \\
\text { 11) Realização } \\
\text { 12) Prudência } \\
\text { 13) Uniformidade } \\
\text { 14) Significação ou impor- } \\
\text { tância relativa } \\
\text { 15) Exposição } \\
\text { [Rueda, Gregorio. Op. citada. } \\
\text { Lima, Peru. 1999.] } \\
\text { Atributos da Informação } \\
\text { Financeira } \\
\text { Clareza, Veracidade, Com- } \\
\text { pleteza e Oportunidade para } \\
\text { ser Util e compreensível. } \\
\text { [Conclusões, I Convenção, } \\
\text { Lima, Peru. 1999.] }\end{array}$ & $\begin{array}{l}\text { Declarações dos Princípios } \\
\text { de Contabilidade - DPC - } 0 \\
\text { a) Postulados ou Princípios } \\
\text { Básicos } \\
\text { Equidade } \\
\text { Pertinência } \\
\text { b) Princípios Gerais } \\
\text { Pressupostos derivados } \\
\text { do ambiente econômico } \\
\text { 1) Entidade } \\
\text { 2) Ênfase no aspecto } \\
\text { econômico } \\
\text { 3) Quantificação } \\
\text { 4) Unidade de medida } \\
\text { Princípios para quantific. } \\
\text { as operações } \\
\text { 1) Valor histórico } \\
\text { 2) Dualidade econômica } \\
\text { 3) Continuidade da } \\
\text { entidade } \\
\text { 4) Realização contábil } \\
\text { 5) Período contábil } \\
\text { Princípios aplicáveis às } \\
\text { Demonstrações Financ. } \\
\text { 1) Objetividade } \\
\text { 2) Importância relativa } \\
\text { 3) Comparabilidade } \\
\text { 4) Revelação suficiente } \\
\text { 5) Prudência } \\
\text { [Carpio, Fernando. Op. } \\
\text { citada. Caracas, 1999.] }\end{array}$ \\
\hline
\end{tabular}




\begin{tabular}{|c|c|c|c|c|c|}
\hline PRINCIPIOS CONTABEIS & ARGENTINA & BRASIL & COLOMBIA & PERU & VENEZUELA \\
\hline Entidade & & $\mathrm{X}$ & $\mathrm{X}$ & $\mathrm{X}$ & $\mathrm{X}$ \\
\hline Continuidade & & $x$ & $\mathrm{x}$ & $\mathrm{x}$ & $\mathrm{x}$ \\
\hline Oportunidade & $X$ & $\mathrm{x}$ & & $\mathrm{x}$ & \\
\hline Registro pelo valor original & & $\mathrm{X}$ & $\mathrm{X}$ & $\mathrm{X}$ & $X$ \\
\hline Atualização monetária & & $\mathrm{X}$ & $\mathrm{X}$ & $\mathrm{X}$ & $X$ \\
\hline Custo como Base de Valor & & $\mathrm{X}$ & $\mathrm{X}$ & $\mathrm{x}$ & $\mathrm{X}$ \\
\hline Denominador Comum Monetário & & $x$ & $x$ & $x$ & $x$ \\
\hline Competência & & $\mathrm{X}$ & $\mathrm{X}$ & $\mathrm{X}$ & $\mathrm{X}$ \\
\hline Confronto Desp., Receitas e Períodos & & $\mathrm{X}$ & $\mathrm{X}$ & & \\
\hline Prudência & & $x$ & $x$ & $\mathrm{X}$ & $\mathrm{X}$ \\
\hline Objetividade & & $\mathrm{X}$ & & $\mathrm{X}$ & $\mathrm{X}$ \\
\hline Materialidade (Relevância) & & $\mathrm{X}$ & $\mathrm{X}$ & $\mathrm{X}$ & $\mathrm{X}$ \\
\hline Consistência (Uniformidade) & $X$ & $\mathrm{X}$ & $\mathrm{x}$ & $\mathrm{x}$ & \\
\hline Confiabilidade & $x$ & $x$ & $x$ & & \\
\hline Aproximação à realidade & $X$ & & & & \\
\hline Essência sobre a Forma & $\mathrm{X}$ & $X$ & $X$ & & \\
\hline Manutenção do Patrimônio & $x$ & & $\mathrm{X}$ & & \\
\hline Revelação & & & $\mathrm{X}$ & $\mathrm{X}$ & $\mathrm{X}$ \\
\hline Equidade & & & & $\mathrm{X}$ & $\mathrm{X}$ \\
\hline Partida Dobrada & & & & $\mathrm{X}$ & $\mathrm{X}$ \\
\hline Bens econômicos & & & & $\mathrm{X}$ & $\mathrm{X}$ \\
\hline Período Contábil & & & $\mathrm{X}$ & $\mathrm{X}$ & $\mathrm{X}$ \\
\hline Pertinência & $\mathrm{X}$ & & $\mathrm{X}$ & & $X$ \\
\hline Comparabilidade & $\mathrm{X}$ & $X$ & $\mathrm{X}$ & & $\mathrm{X}$ \\
\hline Sistematização & $\mathrm{X}$ & & & & \\
\hline Neutralidade & $\mathrm{X}$ & & & & \\
\hline Integridade & $X$ & $X$ & & $\mathrm{X}$ & \\
\hline Verificabilidade & $\mathrm{X}$ & & & $\mathrm{X}$ & \\
\hline Clareza & $\mathrm{X}$ & & & $\mathrm{X}$ & \\
\hline Equilíbrio entre Custos e Benefícios & $\mathrm{X}$ & & & & \\
\hline
\end{tabular}




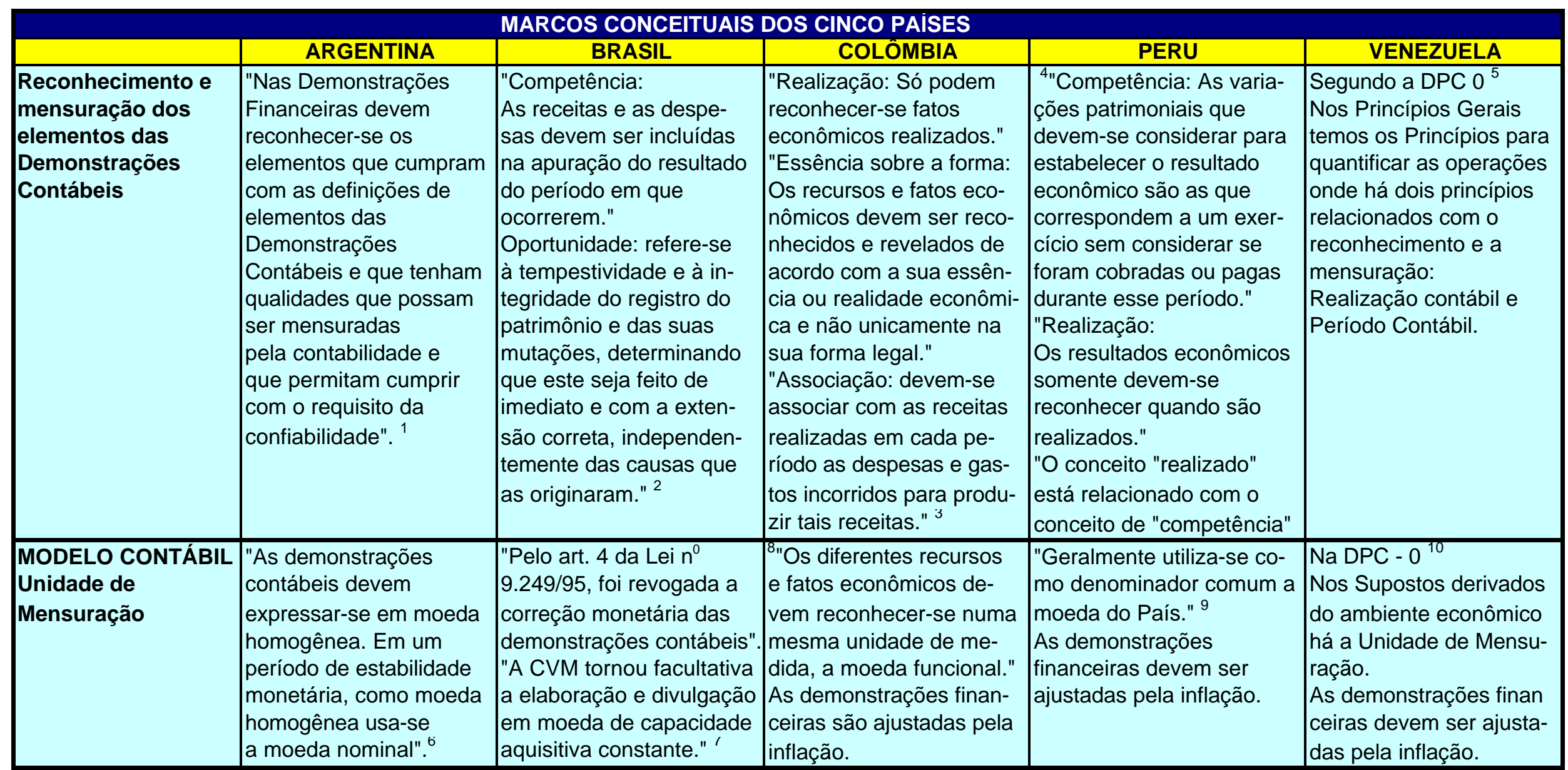

Fonte: ${ }^{1,6}$ Projeto RT 16 citado por Universidade de Buenos Aires. Op. Citada. Pág. 33 e http://www.facpe.org.ar

${ }^{2}$ De ludícibus, Sérgio. Teoria da Contabilidade. São Paulo, 1997. Pág. 85 e 86.

3 e 8 Instituto Nacional de Contadores Públicos. http://www.incp.org.co

${ }^{4}$ e 9 Rueda, Gregorio. Plan Contable General Revisado. Lima, 1999.

5 e ${ }^{10}$ DPC 0 citado por Carpio, Fernando. Catacora. Op. Citada. Caracas, 1999.

${ }^{7}$ De ludícibus, Martins, Gelbcke. Manual de Contabilidade das Sociedades por ações. São Paulo, 1998. p. 444. 


\begin{tabular}{|c|c|c|c|c|c|}
\hline \multicolumn{6}{|c|}{ MARCOS CONCEITUAIS DOS CINCO PAISES } \\
\hline MODELO CONTÁBIL & ARGENTINA & BRASIL & COLÔMBIA & PERU & VENEZUELA \\
\hline $\begin{array}{l}\text { Critérios de } \\
\text { Mensuração }\end{array}$ & $\begin{array}{l}\text { "Ativos: } \\
\text { Custo Histórico } \\
\text { Custo de Reposição } \\
\text { Valor líquido de Reposição } \\
\text { Valor de Utilização econ. } \\
\text { Contas por cobrar: Valor } \\
\text { atual } \\
\text { Participação em outros } \\
\text { ativos: porcentagem sobre } \\
\text { mensurações contábeis } \\
\text { Passivos: } \\
\text { Montante Original } \\
\text { Custo de Pagamento } \\
\text { Valor Atual } \\
\text { Participação em outros } \\
\text { passivos: porcentagem so } \\
\text { bre mensurações } \\
\text { contábeis." } 1\end{array}$ & $\begin{array}{l}\text { "Ativo: }{ }^{2} \\
\text { Custo de aquisição ou } \\
\text { produção } \\
\text { Valor de mercado: } \\
\text { a)das matérias primas } \\
\text { o preço pelo qual pos- } \\
\text { sam ser repostos; } \\
\text { b) dos bens ou direitos } \\
\text { destinados à venda, o } \\
\text { preço líquido de realiza- } \\
\text { ção deduzidas as des- } \\
\text { pesas e a margem de } \\
\text { lucro } \\
\text { Passivos: valor atualiza- } \\
\text { do até a data do balanço } \\
\text { Obrigações em moeda } \\
\text { estrangeira serão conver- } \\
\text { tidos em moeda nacional }\end{array}$ & $\begin{array}{l}\text { "De acordo com as nor- } \\
\text { mas técnicas, são crité- } \\
\text { rios de mensuração } \\
\text { aceitados: } \\
\text { Valor histórico } \\
\text { Valor atual ou de repo- } \\
\text { sição } \\
\text { Valor de realização ou } \\
\text { de mercado } \\
\text { Valor presente" }{ }^{3}\end{array}$ & $\begin{array}{l}\text { São critérios de mensu- } \\
\text { ração: } \\
\text { "Valor de Livros } \\
\text { Valor de Mercado } \\
\text { Valor de participação } \\
\text { patrimonial } \\
\text { Valor de utilização } \\
\text { econômica } \\
\text { Valor líquido realizável } \\
\text { Custo de Reposição } \\
\text { Resultado por Exposição } \\
\text { à Inflação." } 4\end{array}$ & $\begin{array}{l}\text { São critérios de mensu- } \\
\text { ração segundo a DPC } 0^{5} \\
\text { Valor Histórico } \\
\text { Valor Corrigido } \\
\text { Valor recuperável de } \\
\text { uso futuro que pode ser: } \\
\text { Valor líquido realizável } \\
\text { Valor de uso }\end{array}$ \\
\hline Manutenção do Capital & $\begin{array}{l}\text { "Considera-se como ca- } \\
\text { pital a manter o Capital } \\
\text { Financeiro." } 6\end{array}$ & $\begin{array}{l}\text { "O capital considerado } \\
\text { é o capital outorgado } \\
\text { pelos sócios e por capi- } \\
\text { talização de resultados } \\
\text { e reservas. É o capital } \\
\text { financeiro." } 7\end{array}$ & \begin{tabular}{|l|} 
"A entidade econômica \\
tem lucro só depois que \\
seu patrimônio do início \\
foi mantido ou recupera- \\
do. Esta avaliação pode- \\
se fazer do patrimônio \\
financeiro ou do patrimô-- \\
nio físico (operacional)".
\end{tabular} & $\begin{array}{l}\text { De acordo com o IASC: } \\
\text { "A seleção deve estar } \\
\text { baseado nas necessida- } \\
\text { des dos usuários das } \\
\text { demonstrações contá- } \\
\text { beis." } 9\end{array}$ & $\begin{array}{l}\text { De acordo com o IASC: } \\
\text { "A seleção deve estar } \\
\text { baseado nas necessida- } \\
\text { des dos usuários das } \\
\text { demonstrações contá- } \\
\text { beis." } 10\end{array}$ \\
\hline
\end{tabular}

Fonte: ${ }^{1,6,7,9,10}$ Projeto RT 16 citado por Universidade de Buenos Aires. Op. Citada. Pág. 33 e 34 e http://www.facpe.org.ar

${ }^{2}$ Lei $N^{0} 6.404$ de 15 de dezembro de 1976 alterada pela Lei $N^{0} 9.457$ de 5 de maio de 1997. Brasil, 1997. p. 269 - 271.

${ }^{3} \mathrm{e} 8$ Instituto Nacional de Contadores Públicos. http://www.incp.org.co.

${ }^{4}$ Res. N ${ }^{0} 2$ do C.N.C. citado por IVERA ASOCIADOS. Impuesto a la Renta - Ajustes por Inflación. Lima, 1997. p. 424 - 430

${ }^{5}$ DPC 0 citado por Carpio, Fernando Catacora. Op. Citada. Caracas, 1999. 


\section{2.- CONCLUSÕES SOBRE O MARCO CONCEITUAL DOS CINCO}

\section{PAÍSES:}

1) Definição de Contabilidade:

Na definição de Contabilidade, foram encontradas as seguintes diferenças:

A Argentina denomina a Contabilidade como uma "disciplina técnica".

O Brasil a coloca como "semelhante às demais ciências sociais".

A Colômbia apresenta as funções da contabilidade, mas não dá definição dela.

O Peru, na sua legislação fiscal, não dá uma definição. Outros autores deste país a colocam como uma ciência social. 
Para a Venezuela, a contabilidade é uma atividade de serviço, uma disciplina descritiva e analítica, e um sistema de informação. A definição atividade de serviço pode indicar que se refere a ela como uma ciência social.

Nas definições, pode-se observar que todos indicam que é um sistema de informação.

\section{2) Objetivos das demonstrações financeiras:}

Nos objetivos das demonstrações financeiras, há semelhanças porque todos estabelecem como principal objetivo, prover informação sobre o patrimônio, suas mutações, os resultados do exercício; e também indicam como objetivo delas ajudar no planejamento e na tomada de decisões.

\section{3) Hipóteses ou Princípios fundamentais do Sistema:}

Nas Hipóteses ou Princípios fundamentais do Sistema encontramos diferenças de nomenclatura e de enfoque.

A Argentina os denomina Requisitos da Informação Contábil e estão aplicados exclusivamente às demonstrações financeiras. Anteriormente teve um grupo de Princípios, que depois foi substituído na Resolução Técnica no 10 por Qualidades e 
Requisitos da Informação Contábil, e ultimamente, com a RT nº 16, estas Qualidades foram substituídas por Requisitos da Informação Contábil. As Resoluções Técnicas são emitidas pela Federação Argentina de Conselhos Profissionais de Ciências Econômicas - FACPCE. Na Argentina também existe a Federação Argentina de Graduados em Ciências Econômicas - FAGCE que emite normas contábeis.

O Brasil os denomina Princípios Fundamentais de acordo com o Conselho Federal de Contabilidade - CFC. O Instituto Brasileiro de Contadores - Ibracon, que em 2001 teve seu nome oficial alterado para "Ibracon - Instituto Brasileiro de Auditores Independentes" e a Comissão de Valores Mobiliários - CVM também possuem um Pronunciamento denominado Princípios Fundamentais que compreende os Postulados, os Princípios propriamente ditos e as Convenções (Restrições). Estes Princípios têm um campo de abrangência maior, sobre toda a Contabilidade, e também sobre as demonstrações financeiras.

Além destes Princípios, o Brasil tem os Atributos das Demonstrações Financeiras emitidas pelo CFC n 785, aplicáveis às Demonstrações Financeiras. 
A Colômbia possui Normas Básicas emitidas pelo Decreto ํํำ $2649^{49}$ que abrangem toda a Contabilidade, e também possuem as Qualidades da Informação Contábil, que são aplicadas às Demonstrações Contábeis.

A Colômbia tem três organismos que emitem normas, o Instituto Nacional de Contadores Públicos da Colômbia - INCP, a Junta Central de Contadores e a Confederação de Associações de Contadores Públicos da Colômbia.

O Peru os denomina Princípios Gerais, definidos no Plano Contábil Geral Revisado, emitido na Resolução da (CONASEV) Comissão Nacional Supervisora de Empresas e Valores № 00684-EFC/94-10, atualizado segundo a R. CONASEV № 252-85EF/94-01 e Resolução de Contadoria № 005-94-EF/93-01, e seu campo de abrangência corresponde a toda a Contabilidade.

Na I Convenção de Contabilidade ${ }^{50}$ celebrada em 1999, pela F.C.C.P.P. Federação de Colégios de Contadores Públicos do Peru, os Colégios de Contadores estabeleceram um grupo de Atributos da Informação Contábil aplicáveis às Demonstrações Financeiras. No Peru o organismo que emite normas de Contabilidade é o Conselho Nacional de Contabilidade - C.N.C.

\footnotetext{
${ }^{49}$ Régimen Contable Colombiano, 1996 e Instituto Nacional de Contadores Públicos. http://www.incp.org.co ${ }^{50} \mathrm{http}: / /$ www.ccpl.org.pe/
} 
A Venezuela, dentro de sua normas, que são denominadas Declarações de Princípios de Contabilidade - DPC emitidas pela F.C.C.P.V. - Federação de Colégios de Contadores Públicos da Venezuela, tem uma, chamada DPC 0 , que abrange estes Princípios Geralmente Aceitos. Eles estão divididos em dois grupos: Postulados ou Princípios e Princípios Gerais. Dentro dos Princípios Gerais há três grupos denominados Pressupostos Derivados do Ambiente Econômico, Princípios para quantificar as operações e Princípios aplicáveis às Demonstrações Financeiras.

Podemos concluir que Argentina é o país que mais se diferencia dos outros porque seus Requisitos da Informação Contábil somente abrangem as Demonstrações Financeiras; nos outros Países, além dos Princípios ou Normas que abrangem toda a Contabilidade, há os atributos ou as qualidades da informação contábil que estão aplicadas às Demonstrações Financeiras.

\section{4) Análise dos princípios:}

$\mathrm{Na}$ análise dos princípios encontramos as seguintes semelhanças e diferenças:

- O princípio de Entidade, que reconhece o patrimônio como propriedade da entidade, e o princípio da Continuidade, 
necessário para a avaliação dos ativos e passivos, estão presentes em todos os países, com exceção da Argentina.

- A restrição da Oportunidade, que está presente na Argentina, está presente no Brasil como princípio, referindose à sua tempestividade e integridade, sem importar as causas que o originaram. Também está presente no Peru como atributo da informação contábil.

Este princípio não está presente na Colômbia e tampouco na Venezuela.

- No Brasil, há os princípios da CVM e do Ibracon do Custo como Base de Valor, onde o custo de um ativo que vai produzir receitas à empresa representa a base de valor da Contabilidade; e do Denominador Comum Monetário, onde a Unidade de Mensuração é a moeda nacional. Utiliza-se como critérios de mensuração: o valor histórico, o valor corrigido, o valor presente. No Brasil não há correção monetária desde 1996, não obstante a CVM permite que as companhias abertas possam apresentar suas demonstrações financeiras corrigidas.

Na Argentina, não há nenhum requisito semelhante, mas no seu modelo contábil temos que a Unidade de Mensuração 
da Argentina é a moeda homogênea, e em um período de estabilidade é a moeda nominal. Na Argentina não se realizam ajustes por inflação, não obstante nestes últimos meses sua moeda ter sofrido uma desvalorização.

Na Colômbia, os princípios semelhantes são a Unidade de Mensuração e o Princípio de Avaliação ou Mensuração. São critérios de mensuração aceitos o valor histórico, o valor atual, o valor de realização e o valor presente. São realizados os ajustes por inflação nas demonstrações financeiras.

No Peru, os princípios relacionados são Denominador Comum Monetário e Avaliação ao Custo, onde o valor de custo é ajustado devido às flutuações do valor da moeda. As Demonstrações Financeiras devem ser corrigidas pela inflação.

Na Venezuela, os princípios semelhantes são Quantificação, Unidade de Medida, Valor Histórico. As demonstrações financeiras também são corrigidas pela inflação.

- De acordo com o Princípio da Competência do Brasil, as receitas e as despesas são reconhecidas no período quando ocorrerem, sem importar o recebimento ou pagamento. $\mathrm{Na}$ 
CVM e no IBRACON denominam-se Princípio da Realização da Receita e Princípio do Confronto das Despesas com as Receitas e com os Períodos Contábeis.

Na Argentina, este princípio pode estar relacionado com as qualidades de pertinência, confiabilidade, comparabilidade e clareza com as restrições de oportunidade e equilíbrio entre custos e benefícios segundo o Projeto TE $23^{51}$.

$\mathrm{Na}$ Colômbia, os princípios relacionados são de Avaliação ou Mensuração, de Realização e de Associação ou relação de Causalidade.

No Peru, os princípios semelhantes são de Competência e de Realização.

$\mathrm{Na}$ Venezuela, o princípio relacionado é de Realização contábil.

Podemos concluir que há semelhança entre os cinco países no reconhecimento e mensuração das Demonstrações Contábeis, não obstante no Brasil o Princípio do Confronto das Despesas com as Receitas e com os Períodos Contábeis dá uma visão mais completa do tema, e que se

\footnotetext{
${ }^{51}$ UNIVERSIDADE DE BUENOS AIRES. Op. citada. Outubro de 2000. Pág. 32.
} 
corresponde com o Princípio de Associação ou Relação de Causalidade da Colômbia.

- O princípio da Prudência ou do Conservadorismo do Brasil está presente nos outros países, com exceção da Argentina, que considera que não é uma qualidade da informação contábil, já que não existem demonstrações prudentes ou imprudentes. A prudência como atitude dos preparadores das demonstrações financeiras, segundo a RT nํ16, está na aproximação da realidade.

- A objetividade está presente em todos os países, com exceção da Colômbia e da Argentina.

- A Convenção da Materialidade (relevância) do Brasil está presente na Colômbia, no Peru, denomina-se Significação ou Importância Relativa. Na Venezuela, deve estar relacionada com Ênfase no aspecto econômico e Importância Relativa. Na Argentina, não se considera a significação ou relevância como qualidade da informação contábil segundo a $R T n^{0} 16$, porque não há razões para impedir que as demonstrações financeiras mostrem contas não significativas. 
- A Convenção da Consistência (Uniformidade) do Brasil está relacionada com as qualidades da Argentina de Comparabilidade e Clareza.

Este princípio não está presente na Colômbia, tampouco na Venezuela.

No Peru o princípio da Uniformidade está explicitado.

- As qualidades da Verificabilidade e da Clareza, da Argentina, estão presentes no Peru como atributos da informação contábil. Essas qualidades estão relacionadas com Confiabilidade da Colômbia e do Brasil.

- O Requisito de Aproximação à Realidade da Argentina não existe nos outros países. Não obstante, seus componentes essencialidade e integralidade estão presentes em outros países. Este requisito surge porque a informação contábil às vezes não é exata e depende de estimativas. Está em divergência com o princípio true and fair view.

- A qualidade da Essencialidade, da Argentina, também existe na Colômbia denominando-se Essência sobre a Forma. Não há nos outros países. No Brasil, a Essência sobre a Forma está indicada no início do Pronunciamento do CFC como 
requisito da aplicação dos Princípios Fundamentais da Contabilidade.

- O princípio de Manutenção do Patrimônio, da Colômbia, que indica que o patrimônio pode ser financeiro ou físico, só existe como princípio nesse país.

- O princípio de Revelação Plena, da Colômbia, está relacionado com as Qualidades da Argentina de Pertinência, Integridade e Verificabilidade.

No Peru, esse princípio denomina-se Exposição, na Venezuela, é Revelação Suficiente.

- O princípio da Equidade, que indica que nas Demonstrações Financeiras devem refletir-se com equidade os diferentes interesses envolvidos em uma empresa, somente está presente no Peru e na Venezuela.

- O princípio da Partida Dobrada do Peru está relacionado com o princípio da Venezuela de Dualidade Econômica.

- O princípio de bens econômicos do Peru está relacionado com o princípio da Venezuela de Ênfase no Aspecto Econômico. 
- O princípio do Período Contábil está presente na Colômbia, no Peru e na Venezuela.

- O princípio de Comparabilidade está presente na Argentina, no Brasil, na Colômbia e na Venezuela.

- O princípio de Pertinência somente está presente na Argentina e na Colômbia.

- O requisito da confiabilidade da Argentina existe também na Colômbia e no Brasil.

- O requisito de Sistematização, onde se fala sobre o ordenamento de acordo com as normas contábeis, não há nos outros países.

- O requisito de Neutralidade da Argentina não existe nos outros países, mas é similar à convenção da Objetividade do Brasil e à Qualidade, do Peru, e ao Princípio da Venezuela.

- A restrição do Equilíbrio entre Custos e Benefícios da informação contábil da Argentina não existe nos outros países.

- As restrições da Argentina e do Brasil não se correspondem. Nos outros países não se estabelecem restrições. 


\section{5) Elementos das Demonstrações Financeiras:}

Nos Elementos das Demonstrações Financeiras encontramos as seguintes diferenças:

- Na Demonstração da Situação Patrimonial, na Argentina existe um elemento denominado "Participações de acionistas não controladores nos patrimônios de empresas controladas": este elemento existe também no Brasil, nas demonstrações financeiras consolidadas.

- Não há muita diferença nos elementos do Balanço Patrimonial nem tampouco na Demonstração de Resultados. No Balanço Patrimonial, os elementos semelhantes são: ativo, passivo e patrimônio. Na Demonstração de Resultado, os elementos similares são: receitas, despesas, ganhos, perdas, impostos.

- As diferenças estão que no Brasil existe a Demonstração de Lucros ou Prejuízos acumulados, que nos outros países não existe.

- No Brasil continua como obrigatória a Demonstração das Origens e Aplicação de Recursos, que nos outros países foi substituída pela Demonstração de Fluxos de Caixa. 
- Na Venezuela há outras demonstrações não obrigatórias como a Demonstração de Custo de Vendas e a Demonstração de Custo de Vendas e de Produção, que não existem nos outros países.

\section{6) Reconhecimento e Mensuração dos Elementos das}

\section{Demonstrações Contábeis:}

- No Reconhecimento e Mensuração dos Elementos das Demonstrações Contábeis existe bastante semelhança, porque todos aplicam o Princípio da Realização.

- Na Argentina, estabelecem reconhecer os elementos das Demonstrações Contábeis que cumpram com os requisitos solicitados.

\section{7) Modelo Contábil:}

No Modelo Contábil encontramos que:

- Na Unidade de Mensuração há um consenso devido a que todos apresentam suas demonstrações contábeis em moeda homogênea, de cada país. Na Colômbia, no Peru e na Venezuela as demonstrações contábeis são ajustadas pela inflação. 
No Brasil e na Argentina não são corrigidas as demonstrações por força de Leis.

Na Argentina, somente poderão as demonstrações contábeis ser ajustadas quando sua inflação atinja $8 \%$ anuais, de acordo com disposições da CECyT, Centro de Estudos Científicos e Tecnológicos.

No Brasil, de acordo com a CVM, as companhias abertas, além de apresentar as demonstrações financeiras em valores históricos, podem apresentar demonstrações contábeis em moeda de capacidade aquisitiva constante.

- Nos critérios de avaliação podemos observar que são similares: custo histórico, valor de mercado, custo de reposição, valor presente.

- Na Manutenção do Capital vemos que na Colômbia são aceitos o Capital Financeiro e o Capital Físico.

Na Argentina é aceito o Capital Financeiro.

O Brasil não especifica tais categorias de Capital.

No Peru e na Venezuela, como aceitam as normas do IASC, seu capital será baseado nas necessidades dos usuários. 


\section{4. - ALGUMAS DIFERENÇAS E SEMELHANÇAS NA CONTABI LI DADE}

Neste capítulo apresentam-se algumas das principais semelhanças e diferenças na contabilidade dos cinco países citados:

\section{1.- DEMONSTRAÇÕES FINANCEIRAS}


$\mathrm{Na}$ Argentina, de acordo com a Comissão Nacional de Valores - CNV Resolução 195/92, são obrigatórias as seguintes demonstrações: ${ }^{52}$

- Demonstração da Situação Patrimonial.

- Demonstração de Resultado.

- Demonstração da Evolução do Patrimônio Líquido.

- Demonstração das Origens e Aplicações de Recursos (DOAR).

- Informações complementares.

- Notas explicativas.

As Leis $\mathrm{n}^{\text {ss }} 19.550 / 72$ e $22.903 / 83$ consideram obrigatórias as seguintes demonstrações: ${ }^{53}$

- Balanço Geral.

- Demonstração de Resultado.

- Notas Complementares, Quadros e Anexos.

A Federação Argentina de Conselhos Profissionais de Ciências Econômicas FACPCE, através do RT no 08 e RT n 09, considera obrigatórias as seguintes demonstrações: ${ }^{54}$

- Demonstração da Situação Patrimonial

- Demonstração de Resultado.

- Demonstração da Evolução do Patrimônio Líquido.

\footnotetext{
${ }^{52}$ CRC de São Paulo. Contabilidade no Contexto Internacional - 9. São Paulo, 1997. 147.

${ }^{53}$ CRC de São Paulo. Contabilidade no Contexto Internacional - 9. São Paulo, 1997. 146.

${ }^{54}$ CRC de São Paulo. Contabilidade no Contexto Internacional - 9. São Paulo, 1997. 148.
} 
- Demonstração de Variações do Capital Circulante ou Demonstrações de Origens e Aplicações de recursos;

- Demonstrações Consolidadas;

- Notas Complementares.

De acordo com o FACPCE, ${ }^{55}$ a RT $n^{0} 19$ que modifica a RT $n^{0}$ 8, dispõe que as demonstrações básicas são:

- Demonstração da Situação Patrimonial ou Balanço Geral;

- Demonstração de Resultados (nas entidades sem fins de lucro, Demonstração de Recursos e Despesas);

- Demonstração da evolução do Patrimônio Líquido;

- Demonstração dos Fluxos de Caixa.

As demonstrações devem mostrar sua informação complementar.

Demonstrações Complementares:

- Demonstração da Situação Patrimonial ou Balanço Geral consolidado;

- Demonstração de Resultados Consolidado;

- Demonstração dos Fluxos de Caixa Consolidado.

As demonstrações devem mostrar sua informação complementar.

No Brasil, de acordo com Resumo contido na Publicação $10 B{ }^{56}$ a obrigatoriedade de apresentar demonstrações financeiras está legislada pela Lei

\footnotetext{
${ }^{55} \mathrm{http} / / / \mathrm{www}$.facpce.org.ar

${ }^{56}$ IOB, Temática Contábil e Balanços. Demonstrações financeiras obrigatórias. Janeiro de 2000 - № 3. p.9- 11 .
} 
das S.A., que obriga a todas as companhias (art. 176 da Lei $n^{0} 6.404 / 76$ ), e pela legislação do Imposto de Renda, que obriga às empresas tributadas com base no lucro real (art. 274 do RIR/99).

São obrigatórias as seguintes demonstrações contábeis:

- Balanço patrimonial

- Demonstração do resultado do exercício

- Demonstração de lucros ou prejuízos acumulados

- Demonstração das origens e aplicações de recursos (companhias abertas e companhias fechadas com patrimônio líquido superior a um milhão de reais).

"O levantamento dessas demonstrações financeiras deve ser feito:

- para o atendimento do disposto na lei societária, na data do encerramento do exercício social, conforme dispuser o estatuto ou contrato social; $e$

- para o atendimento das determinações da legislação do Imposto de Renda, na data de encerramento do período-base de apuração do lucro real',57.

De acordo com a mesma fonte, 0 $2^{0}$ do art. 186 da Lei $n^{0} 6.404 / 76$ permite que a Demonstração de Lucros ou Prejuízos Acumulados seja incluída na Demonstração das Mutações do Patrimônio Líquido. Esta última demonstração é obrigatória somente nas companhias abertas e facultativa nas outras.

A apresentação do DOAR, segundo a mesma fonte, é obrigatória somente nos seguintes casos (art. 176 da Lei $n^{0}$ 6.404/76 ): 
- companhias abertas;

- companhias fechadas quando o patrimônio líquido na data do balanço for superior a $\mathrm{R} \$ 1.000 .000,00$ (um milhão de reais)

De acordo com a mesma fonte, as demonstrações financeiras consolidadas como informação complementar são obrigatórias nos seguintes casos (arts. 249 e 250 da Lei n- 6.404/76 e 21 da Instrução CVM n- 247/96):

"I - companhia aberta que possuir investimento em sociedades controladas, incluindo as sociedades controladas em conjunto; aberta.

II - sociedade de comando de grupo de sociedades que inclua companhia As demonstrações contábeis consolidadas compreendem:

a) o balanço patrimonial consolidado;

b) a demonstração consolidada do resultado do exercício; e

c) a demonstração consolidada das origens e aplicações de recursos. Notas explicativas". 58

O Conselho Federal de Contabilidade - CFC, de acordo com as NBC-T-3, NBC-T-6 e NBC-T-8 considera demonstrações contábeis básicas: ${ }^{59}$

- Balanço Patrimonial

- Demonstração de resultados

\footnotetext{
${ }^{57}$ IOB, Temática Contábil e Balanços. Demonstrações financeiras obrigatórias. Janeiro de 2000 - № 3 . p.9- 11 .

${ }^{58}$ IOB, Temática Contábil e Balanços. Demonstrações financeiras obrigatórias. Janeiro de $2000-\mathrm{N}^{0} 3$. p.9- 11 .

${ }^{59}$ CRC de São Paulo. Contabilidade no Contexto internacional - 9. São Paulo, 1997. p.148.
} 
- Demonstração das mutações do patrimônio líquido ou demonstração dos lucros ou prejuízos acumulados.

- Demonstração das origens e aplicações de recursos.

O Instituto Brasileiro de Contadores (IBRACON) revisou e atualizou, em abril de 1999, a Norma Brasileira de Contabilidade, NBC 20, que trata da elaboração e apresentação da Demonstração dos Fluxos de Caixa.

Enquanto as disposições legais mantiverem a exigibilidade de preparação da Demonstração das Origens e Aplicações de Recursos eles recomendam a apresentação da Demonstração dos Fluxos de Caixa como informação complementar.

Na Colômbia, de acordo com o D.R. 2649/93, as demonstrações básicas são: ${ }^{60}$

- Balanço Geral ou Demonstração da Situação Patrimonial

- Demonstração de resultados

- Demonstração da Evolução do Patrimônio líquido

- Demonstração de Mudanças na Situação Financeira

- Demonstração dos Fluxos de Caixa

No Peru, as empresas devem preparar as demonstrações financeiras de acordo com as normas da $\operatorname{CONASEV}^{61}$. Segundo este organismo, são obrigatórias as seguintes demonstrações financeiras:

\footnotetext{
${ }^{60} \mathrm{http}: / / \mathrm{www}$. incp.org.co
} 
- Balanço Geral ou Demonstração da Situação Patrimonial

- Demonstração de Resultados

- Demonstração da evolução do Patrimônio Líquido

- Demonstração dos Fluxos de Caixa.

As Demonstrações Financeiras devem incluir as notas às Demonstrações Financeiras. Estas Demonstrações Financeiras serão apresentadas ajustadas pela inflação e em forma comparativa por períodos consecutivos.

$\mathrm{Na}$ Venezuela, a DPC- $0^{62}$ indica as principais instituições de tipo profissional no contexto internacional e suas definições das demonstrações financeiras ou contábeis. Em sentido amplo, as demonstrações financeiras, objetivo da contabilidade, incluem as seguintes:

- Balanço geral.

- Demonstração de Resultados.

- Demonstração do Custo de Vendas e Demonstração do Custo de Produção e Vendas (não obrigatório).

- Demonstração das Mudanças no Patrimônio Líquido.

- Demonstração dos Fluxos de Caixa.

- Notas às Demonstrações Financeiras.

\footnotetext{
${ }^{61}$ CONASEV. Reglamento para la Preparación de Información Financiera e Información Auditada. Lima,1998. p.21.

${ }^{62}$ Carpio, Fernando Catacora. PCGA en Venezuela. Comentarios y Análisis de todas las Declaraciones y Principios de Contabilidad vigentes en Venezuela. Caracas, 1999.
} 


\begin{tabular}{|c|c|c|c|c|}
\hline ARGENTINA & BRASIL & COLÔMBIA & PERU & VENEZUELA \\
\hline $\begin{array}{l}\text { L. } \mathbf{n}^{0} \text { 19.550/72 e } \\
22.903 / 83 \\
\text { Balanço Geral } \\
\text { Demonstração de Resultado } \\
\text { Notas Complementares, } \\
\text { Quadros e Anexos } \\
\text { Federação Argentina de } \\
\text { Conselhos } \\
\text { Profissionais de Ciências } \\
\text { Econômicas } \\
\text { FACPCE } \\
\text { RT-08 e RT-09 } \\
\text { Demonstração da Situação } \\
\text { Patrimonial } \\
\text { ou Balanço Geral } \\
\text { Demonstração de Resultado } \\
\text { Demonstração da Evolução } \\
\text { do Patrimônio Líquido } \\
\text { Demonstração dos Fluxos } \\
\text { de Caixa } \\
\text { Demonstrações } \\
\text { Consolidadas } \\
\text { Notas Complementares }\end{array}$ & $\begin{array}{l}\text { Lei 6.404/76 } \\
\text { art 274 do RIR/90 } \\
\text { Balanço Patrimonial } \\
\text { Demonstração do Resultado } \\
\text { do Exercício } \\
\text { Demonstração de Lucros ou } \\
\text { Prejuízos Acumulados } \\
\text { Demonstração das Origens e } \\
\text { Aplicação de Recursos } \\
\text { Notas Explicativas } \\
\\
\text { Conselho Federal de } \\
\text { Contabilidade } \\
\text { NBC-T-3, NBC-T6, NBC-T8 } \\
\text { Balanço Patrimonial } \\
\text { Demonstração do Resultado } \\
\text { Demonstração das Mutações } \\
\text { do Patrimônio Líquido ou } \\
\text { Demonstração de Lucros ou } \\
\text { prejuízos Acumulados } \\
\text { Demonstração das Origens e } \\
\text { Aplicações de Recursos } \\
\text { Notas Explicativas }\end{array}$ & \begin{tabular}{|l|}
\multicolumn{1}{|c|}{ (D.R. 2649/93) } \\
Balanço Geral \\
Demonstração de Resultados \\
Demonstração da Evolução do \\
Patrimônio Líquido \\
Demonstração de Mudanças \\
na Situação Financeira \\
Demonstração dos Fluxos de \\
Caixa
\end{tabular} & \begin{tabular}{|l}
\multicolumn{1}{c|}{$\begin{array}{l}\text { (Conasev N 006/84- } \\
\text { EFC 94-10) }\end{array}$} \\
Balanço Geral ou \\
Demonstração da \\
da Situação Patrimonial \\
Demonstração de Resultados \\
Demonstração da Evolução do \\
Patrimônio Líquido \\
Demonstração dos Fluxos de \\
Caixa
\end{tabular} & $\begin{array}{l}\text { DPC - } 0 \\
\text { Balanço Geral } \\
\text { Demonstração de Resultados } \\
\text { Estado de custo de vendas e } \\
\text { Estado de custo de produção } \\
\text { e vendas } \\
\text { (não obrigatório) } \\
\text { Demonstração das Mudanças } \\
\text { no Patrimônio Líquido } \\
\text { Demonstração dos Fluxos de } \\
\text { Caixa } \\
\text { Notas às Demonstrações } \\
\text { Financeiras }\end{array}$ \\
\hline
\end{tabular}


4.2.- DEMONSTRAÇÃO DA SITUAÇÃO PATRIMONIAL

Demonstração da Situação Patrimonial na Argentina 
"De acordo com as Resoluções Técnicas (RT) 8 e 9 da Federação Argentina de Conselhos Profissionais de Ciências Econômicas, a Demonstração da Situação Patrimonial ou Balanço Geral em um momento determinado mostra o ativo, o passivo e o patrimônio líquido e, se for o caso, a participação minoritária em sociedades controladas. ${ }^{, 63}$

\section{Balanço Patrimonial no Brasil}

"De acordo com as Normas Brasileiras de Contabilidade - Técnicas NBC T, aprovadas pelo Conselho Federal de Contabilidade (CFC) - NBC - T-3, o Balanço Patrimonial é a demonstração contábil destinada a expor, quantitativa e qualitativamente, numa determinada data, o patrimônio da entidade. ${ }^{, 64}$

O Balanço Patrimonial é constituído por Ativo, Passivo e Patrimônio Líquido.

\section{Balanço Patrimonial na Colômbia.}

No Balanço Patrimonial na Colômbia, "os ativos, passivos e o patrimônio, devem ser reconhecidos em forma tal que ao relacionar uns com outros, se possa determinar razoavelmente a situação financeira da entidade econômica em uma data determinada" 65

É constituído pelo Ativo, Passivo e Patrimônio Líquido.

\footnotetext{
${ }^{63}$ CRC de São Paulo. Contabilidade no Contexto Internacional - 9. São Paulo, 1997. 155.

${ }^{64}$ CRC de São Paulo. Contabilidade no Contexto Internacional - 9. São Paulo, 1997. 155.

${ }^{65}$ http://www.incp.org.co
} 


\section{Balanço Geral no Peru}

Segundo o Plano Contábil Geral Revisado, Resolução Conasev № 006-84EF/94.01, "o Balanço Geral é a demonstração financeira que apresenta, em uma data determinada, a origem dos recursos utilizados nas operações de uma empresa (Passivo e Patrimônio líquido), assim como os bens e direitos onde foram investidos esses recursos. (Ativo)" ${ }^{66}$.

O Balanço Geral é constituído por Ativo, Passivo e Patrimônio Líquido.

A estrutura da Demonstração da Situação Patrimonial nos cinco países é a seguinte:

\footnotetext{
${ }^{66}$ Ruedas, Gregório. Op. Citada. Lima, 1999. p. 30.
} 


\begin{tabular}{|c|c|c|c|c|}
\hline \multicolumn{5}{|c|}{ DEMONSTRAÇÃO DA SITUAÇÃO PATRIMONIAL } \\
\hline ARGENTINA ${ }^{1}$ & BRASIL $^{2}$ & COLÔMBIA ${ }^{3}$ & PERU $^{4}$ & VENEZUELA ${ }^{5}$ \\
\hline 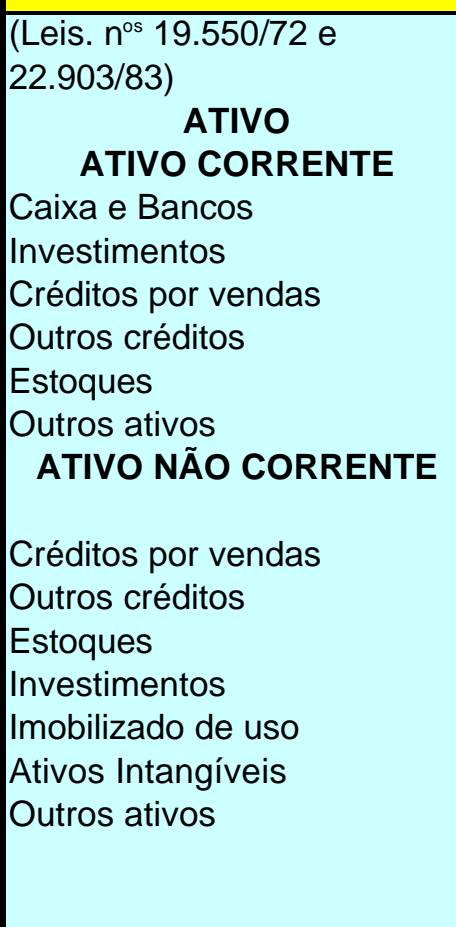 & \begin{tabular}{l} 
ATIVO \\
\multicolumn{1}{c}{ (Lei 6.404/76) } \\
\multicolumn{1}{c}{ ATIVO CIRCULANTE } \\
Disponibilidades \\
Créditos \\
Estoques \\
Despesas Antecipadas \\
Outros Valores e Bens \\
$\quad$ ATIVO REALIZÁVEL A \\
$\quad$ LONGO PRAZO \\
Créditos \\
Estoques \\
Despesas Antecipadas \\
Outros Valores e Bens \\
\multicolumn{1}{c}{ ATIVO PERMANENTE } \\
Investimentos \\
Imobilizado \\
Diferido
\end{tabular} & 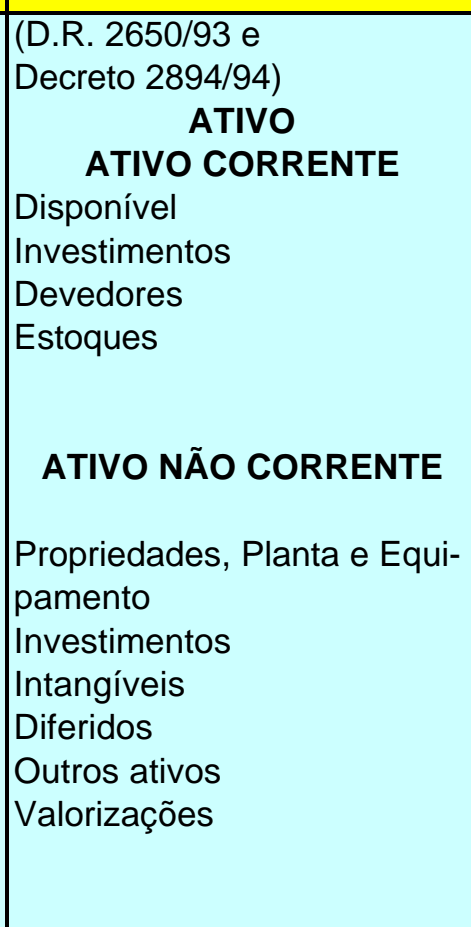 & \begin{tabular}{l} 
(R. Conasev N 006-84- \\
EFC/94-10) \\
\multicolumn{1}{c}{ ATIVO } \\
\multicolumn{1}{c}{ ATIVO CORRENTE } \\
Caixa e Bancos \\
Créditos \\
Estoques \\
Investimentos a curto prazo \\
\\
ATIVO NÃO CORRENTE \\
Imobilizado \\
Investimentos permanentes \\
Intangíveis \\
Despesas diferidas \\
Outros ativos
\end{tabular} & \begin{tabular}{l}
$\quad$ ATIVO \\
\multicolumn{1}{c}{ ATIVO CORRENTE } \\
Disponível \\
Investimentos a curto prazo \\
Contas por Cobrar \\
Estoques \\
Pré-pagamentos \\
\multicolumn{1}{c}{ ATIVO NÃO CORRENTE } \\
Investimentos em longo prazo \\
Ativo Fixo Tangível \\
Ativo Fixo Intangível \\
Despesas Diferidas e outros \\
Outros ativos
\end{tabular} \\
\hline
\end{tabular}

Fonte:

${ }^{1}$ CRC de São Paulo. Contabilidade no Contexto Internacional - 9. São Paulo, 1997. p.149.

${ }^{2}$ CRC de São Paulo. Contabilidade no Contexto Internacional - 9. São Paulo, 1997. p.149.

${ }^{3}$ Régimen Contable Colombiano. Bogotá, 1996. p. 471 - 490.

${ }^{4}$ Ruedas, Gregorio. Plan Contable General Revisado. Lima, 1999. p.135.

${ }^{5}$ Carpio, Fernando Catacora. Op. Citada. Caracas, 1999. 


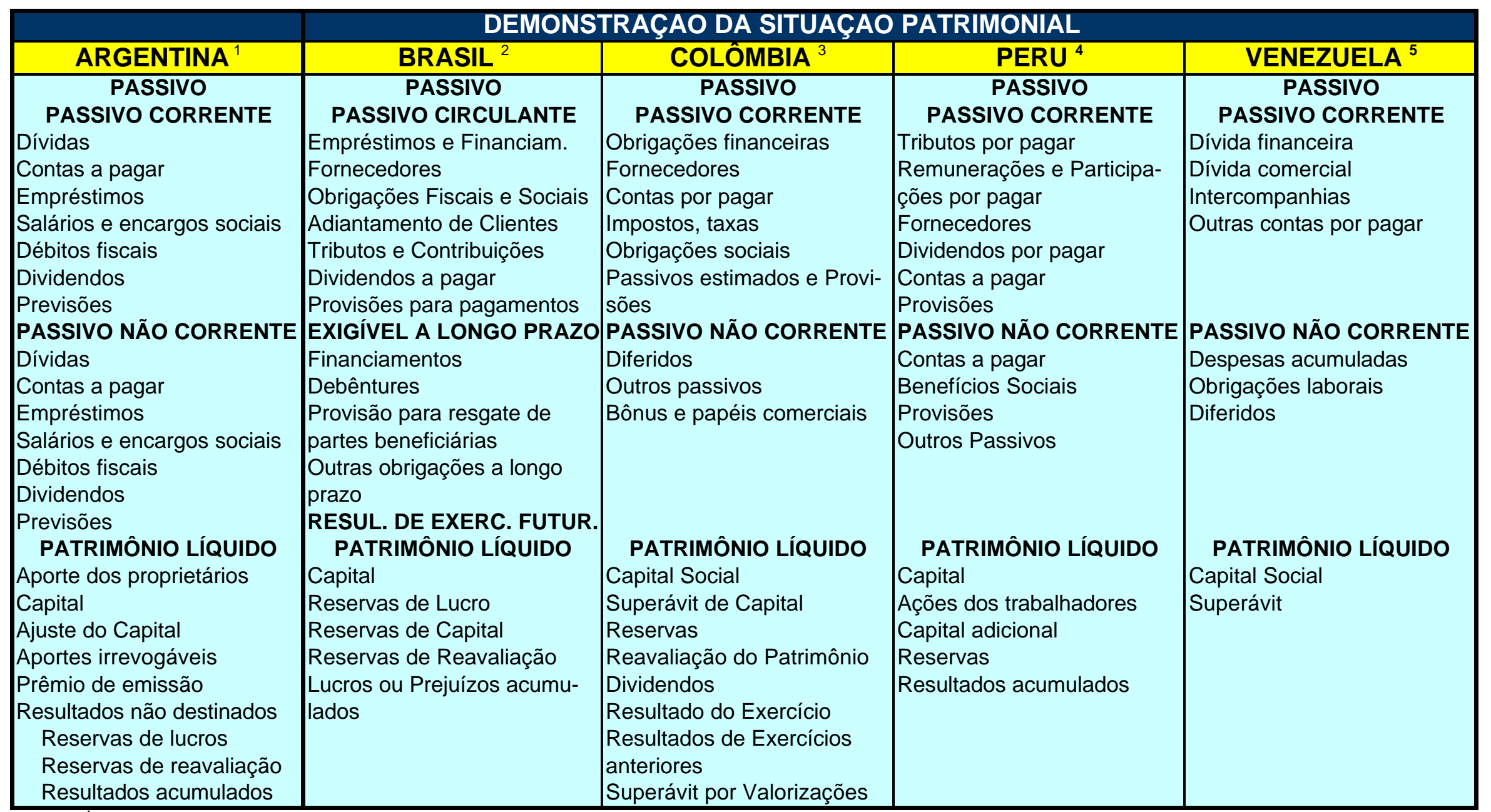

Fonte: ${ }^{1}$ CRC de São Paulo. Contabilidade no Contexto Internacional - 9. São Paulo, 1997. p.149

${ }^{2}$ CRC de São Paulo. Contabilidade no Contexto Internacional - 9. São Paulo, 1997. p.149.

${ }^{3}$ Régimen Contable Colombiano. Bogotá, 1996. p. 471 - 490.

${ }^{4}$ Ruedas, Gregorio. Plan Contable General Revisado. Lima, 1999. p.135.

${ }^{5}$ Carpio, Fernando Catacora. Op. Citada. Caracas, 1999. 


\subsection{1.- CONCLUSÕES SOBRE A DEMONSTRAÇÃO DA SITUAÇÃO}

\section{PATRIMONIAL:}

- É possível observar que, no Ativo, a maior diferença está no Brasil, que classifica em três grupos: Circulante, Realizável a Longo Prazo e Permanente. Nos outros países, a classificação é em dois grupos Corrente e Não Corrente. Não existe a classificação de Ativo Permanente, em que no Brasil são classificados os bens e direitos de caráter permanente. Nos outros países, esses ativos são classificados no Ativo não Corrente.

- No Brasil, a classificação do Passivo é Circulante, Exigível a Longo Prazo, Resultados de Exercícios Futuros e Patrimônio Líquido; nos outros países, a classificação do Passivo é dividida em corrente e não corrente.

- Há semelhanças na classificação dos direitos e as obrigações quando o prazo de realização é um ano. O Brasil classifica essas contas no Ativo Circulante e no Passivo Circulante. Os outros países registram essas contas no Ativo Corrente e no Passivo Corrente.

- Quando os prazos esperados de realização dos direitos e as obrigações forem maior que um ano, o Brasil classifica essas 
contas no Realizável e Exigível a longo prazo, e os outros países registram essas contas no Ativo não Corrente e no Passivo não Corrente.

- A conta do Brasil Resultados de Exercícios futuros não existe nos outros países.

\section{3.- DIFERENÇAS E SEMELHANÇAS PRINCIPAIS NA CONTABILIDADE}

Algumas das principais diferenças e semelhanças na contabilidade dos cinco países estão nos seguintes grupos de contas:

\subsection{1.- CONCLUSÕES SOBRE OS ESTOQUES}

1) Regra comum na avaliação dos estoques:

Nas avaliações dos estoques, há uma regra comum que é custo ou mercado, dos dois o menor. Esta regra significa que nenhum ativo deve estar registrado por um valor maior do que de fato vale economicamente para a empresa. Dessa forma, não é possível deixar que um estoque seja avaliado pelo custo de sua aquisição ou fabricação se esse valor não vai ser recuperado na sua venda. 
$\mathrm{Na}$ Argentina, esta regra está definida segundo a $\mathrm{RT} \mathrm{n}^{0} 17^{67}$ assim:

"Nenhum ativo poderá apresentar-se nas demonstrações financeiras por um valor superior a seu valor recuperável, que é o maior valor entre:

- $\quad$ seu valor líquido de realização (VLR);

- seu valor de uso, definido como o valor atual esperado dos fluxos líquidos de fundos que deveriam surgir do uso dos bens e de sua disposição no final de sua vida útil (ou de sua venda antecipada).

No caso dos estoques, a comparação com o valor recuperável se efetuará considerando a forma de utilização ou comercialização dos bens".

No Brasil, de acordo com o Ibracon, ${ }^{68}$ devem realizar-se as mensurações posteriores quando houver perda de utilidade ou outros fatores, "deve-se assumir como base final de avaliação tal valor líquido de realização".

"Reduzir o custo de um bem de estoque somente até o valor de mercado não é adequado , quando de, antemão, pode-se estimar

\footnotetext{
${ }^{67} \mathrm{http}: / /$ facpce.com.ar
} 
que o preço líquido esperado de venda no futuro, menos os custos, é inferior a esse valor de mercado na data do balanço."

\section{2) Avaliação dos estoques em geral:}

$\mathrm{Na}$ avaliação dos estoques em geral encontramos que:

Na Argentina, segundo a RT n $17,{ }^{69}$ "os estoques em geral serão avaliados a seu custo de reposição na data das demonstrações contábeis. Se não fosse possível se utilizará o custo original."

No Brasil, de acordo com o Conselho Federal de Contabilidade ${ }^{70}$ NBC - T 4, encontramos que:

"Os estoques de mercadorias, matérias primas, produtos acabados e em elaboração e os serviços em andamento são avaliados pelo custo de aquisição ou produção corrigidos ou pelo valor de mercado, o menor."

No Brasil, de acordo com a Lei das Sociedades por Ações, ${ }^{71}$ "os estoques serão avaliados pelo custo de aquisição ou produção,

\footnotetext{
${ }^{68}$ IOB. Temática Contábil e Balanços. Normas e Procedimentos de Contabilidade do IBRACON - NPC 02 Estoques - Texto revisado e atualizado em 1999. São Paulo, 1999. p. 6-8.

${ }^{69} \mathrm{http} / / /$ facpce.com.ar

${ }^{70}$ CFC. Princípios Fundamentais de Contabilidade e normas brasileiras de Contabilidade. São Paulo, 1995.

${ }^{71}$ Lei N 6.404/76 alterada pela Lei n 9.457 de 5 de maio de 1997. Brasília, 1997.p. 269-270.
} 
deduzido de provisão para ajustá-lo ao valor de mercado, quando este for inferior".

De acordo com o IBRACON, ${ }^{72}$ "o principal critério para avaliação dos estoques é o do custo ou valor líquido de realização, o que for menor.".

Na Colômbia, ${ }^{73}$ "o valor dos estoques, o qual inclui todas as despesas diretas e indiretas necessárias para colocá-los em condições de utilização ou venda deve ser determinado usando os métodos de avaliação".

Antes, os estoques tinham de ser corrigidos pela inflação, isso foi modificado ${ }^{74}$.

"No final do período devem reconhecer-se as contingências de perda dos estoques, mediante as provisões necessárias para ajustá-los a seu valor líquido de realização”.

No Peru, ${ }^{75}$ "na avaliação dos estoques no final do exercício deve considerar-se como base o "custo de aquisição ou mercado, o mais baixo". Se este valor for menor que o valor em livros, a diferença deve ser provisionada, utilizando-se a conta Provisão

\footnotetext{
${ }^{72}$ IOB. Temática Contábil e Balanços. Normas e Procedimentos de Contabilidade do IBRACON - NPC 02 Estoques - Texto revisado e atualizado em 1999. São Paulo, 1999. p. 6-8.

${ }^{73}$ Régimen Contable Colombiano. Bogotá, 1996. p. 263 - 285.

${ }^{74}$ http://incp.org.co
} 
para Desvalorização de Existências". Considera-se como valor de mercado o valor líquido de realização.

No Peru os estoques são corrigidos pela inflação.

76 “Ajusta-se o valor em livros, excluindo as diferenças de câmbio alocadas no estoque".

Para efeitos tributários, a partir de 1996, o ajuste por inflação terá no caso dos estoques como limite o Valor de Reposição, que em nenhum caso poderá ser menor que os respectivos valores de aquisição ou de entrada no patrimônio.

$\mathrm{Na}$ Venezuela ${ }^{77}$ "o valor ajustado por índices de preços está sujeito à norma do menor entre o custo ajustado e o valor recuperável”.

"No IAS 2, os estoques devem ser avaliados pelo custo histórico ou pelo valor realizável líquido, dos dois o menor, numa base FIFO (First In First Out) ou custo médio ponderado (alternativas preferidas).

A base LIFO (Last In First Out) é uma alternativa aceitável, mas se for adotada, a valorização por meio de uma das alternativas

\footnotetext{
${ }^{75}$ RUEDA, Gregorio. Plan ContableGeneral Revisado. Lima, 1999. p. 61-71.

${ }^{76}$ IVERA ASOCIADOS. Impuesto a la Renta - Ajustes por Inflación. Lima, 1999. p. 434 - 436.
} 
preferidas deve ser divulgada também. Não é obrigatório alocar todas as despesas gerais indiretas de produção aos estoques".78

\section{3) Estoques fungíveis:}

No caso dos estoques fungíveis, observa-se que:

$\mathrm{Na}$ Argentina, de acordo com a RT $\mathrm{n}^{0} 17,{ }^{79}$ "os estoques fungíveis, com mercado transparente, comercializados sem esforço significativo serão avaliados a valor líquido de realização".

No Brasil, de acordo com a Lei das Sociedades por Ações, ${ }^{80}$ "os estoques de mercadorias fungíveis destinadas à venda poderão ser avaliados pelo valor de mercado, quando esse for o costume mercantil".

\section{4) Adiantamentos nos estoques:}

Na Argentina, segundo a RT $\mathrm{n}^{0} 17,{ }^{81}$ "os estoques sobre os que se receberam antecipos que fixam preço e as condições contratuais da operação que certifiquem a concretização da venda e da receita serão avaliados a valor líquido de realização”.

\footnotetext{
${ }^{77}$ CARPIO, Fernando Catacora. PCGA en Venezuela. Comentarios y Análisis de todas las Declaraciones y Principios de Contabilidad vigentes en Venezuela. Caracas, 1999.

${ }^{78}$ CFC. Contabilidade no contexto internacional - 9. São Paulo, 1997.

${ }^{79} \mathrm{http}: / /$ facpce.com.ar

${ }^{80}$ Lei N 6.404/76 alterada pela Lei n 9.457 de 5 de maio de 1997. Brasília, 1997.p. 270.

${ }^{81} \mathrm{http}: / /$ facpce.com.ar
} 
No Brasil, de acordo com o lbracon, ${ }^{82}$ "os valores pagos adiantadamente a fornecedores de materiais que irão compor os estoques são considerados como aplicação de recursos visando à formação de estoques futuros, e como tal devem ser registrados".

Isto significa que tanto na Argentina como no Brasil os pagamentos adiantados são considerados como estoques.

\section{5) Estoques em produção ou construção:}

$\mathrm{Na}$ Argentina, de acordo com a RT $\mathrm{n}^{-0} 17,{ }^{83}$ os estoques em produção ou construção durante um tempo prolongado serão avaliados pelo valor líquido de realização, de acordo com o grau de avanço da produção ou construção e dos resultados, nos seguintes casos:

- "foram recebidos antecipos que fixam preço;

- as condições contratuais da operação certifiquem a concretização da venda;

- a entidade tenha a capacidade financeira para finalizar a obra;

- exista certeza da concretização da receita.

\footnotetext{
${ }^{82}$ IOB. Temática Contábil e Balanços. Normas e Procedimentos de Contabilidade do IBRACON - NPC 02 Estoques - Texto revisado e atualizado em 1999. São Paulo, 1999. p. 6-8.

${ }^{83} \mathrm{http}: / /$ facpce.com.ar
} 
- Nos casos que fiquem, serão avaliados pelo custo de reposição dos bens, ou se isto não fosse possível, seu custo de reprodução, e se ainda não fosse possível será usado o custo original”.

\section{6) Estoques de animais, e de produtos agrícolas e extrativos}

No Brasil, segundo o $\mathrm{CFC}^{84}$ os estoques de animais, e de produtos agrícolas e extrativos destinados à venda serão avaliados a valor de mercado se cumprir com as seguintes condições:

- "que a atividade seja primária;

- que o custo de produção seja de difícil determinação;

- que haja um efetivo mercado que possibilite a liquidez imediata desse estoque e que valide a formação do seu preço;

- que seja possível estimar o montante das despesas de realização da venda".

\footnotetext{
${ }^{84}$ CFC Op. citada. São Paulo, 1995.
} 
Na Colômbia, "nas plantações agrícolas, o estoque permanente controla suas existências e custos, utiliza-se um sistema de amortização dependente de seu ciclo agronômico, e não há necessidade que o sistema de estoque exija um controle por unidades".

\section{7) Estoques obsoletos:}

No Brasil, segundo o $\mathrm{CFC},{ }^{86}$ "os estoques obsoletos ou inservíveis são avaliados pelo valor líquido de realização e os estoques invendáveis devem ser baixados".

\section{8) Avaliação pelo Fisco}

Na Argentina, de acordo com o Fisco, a avaliação dos estoques é pelo seu valor de aquisição.

No Brasil, de acordo com o Regulamento do Imposto de Renda, os estoques devem ser avaliados pelo custo de aquisição.

Na Colômbia, é custo histórico ou valor líquido de realização, o menor.

\footnotetext{
${ }^{85}$ Régimen Contable Colombiano. Bogotá, 1996. p. 263 - 285.

${ }^{86}$ CFC. Op. citada. São Paulo, 1995.
} 
No Peru, é custo corrigido considerando como limite o custo de reposição.

Na Venezuela, é custo corrigido ou o valor recuperável, o menor.

\section{9) Métodos de Avaliação:}

Na Argentina, de acordo com o Fisco, o método de avaliação de estoques é o UEPS (Último a entrar, Primeiro a sair) ou LIFO. Na prática, utilizam-se Valores Correntes e o método LIFO não é praticado.

No Brasil, de acordo com o Regulamento do Imposto de Renda, "o custo médio ponderado móvel e o PEPS (Primeiro a entrar, Primeiro a sair) ou FIFO serão utilizados quando a entidade possua inventário permanente, quando não ocorra isso somente será aceitável o PEPS 87 .

No Brasil, segundo o Ibracon, os métodos mais utilizados são os seguintes:
a) Custo Médio;
b) Primeiro a entrar, Primeiro a sair (PEPS);
c) Identificação específica;
d) Custo-Padrão;

\footnotetext{
${ }^{87}$ FIPECAFI e Arthur Andersen apud Da Rosa, Paulo. A contabilidade no Mercosul. São Paulo, 1999. p. 104.
} 
e) Método do Varejo.

Na Colômbia "s8 "são três os métodos de avaliação:
a) UEPS ou LIFO;
b) PEPS ou FIFO;
c) Custo Médio.

Devido a lei que não determinou nem limitou os métodos de avaliação de estoques, pode-se utilizar outros métodos como: o Método de Identificação específica, o "Método de Varejo", o "Método da Receita bruta".

O "Método de Varejo",9 é utilizado por empresas que vendem grande quantidade de artigos no varejo.

"O método está baseado no pressuposto de que a relação entre o custo da mercadoria disponível para a venda e o preço no varejo é determinado no momento da compra. As mercadorias devem classificar-se por grupos homogêneos que recebem um preço de venda a partir do custo de compra e da margem da receita bruta. Neste método, o custo do inventário final é determinado assim:

Mercad. disponível para a venda ao custo $X$ Valor do estoque final Mercad. disponível para a venda ao preço das mercadorias ao

\footnotetext{
${ }^{88}$ Régimen Contable Colombiano. Bogotá, 1996. p. 263 - 285.

${ }^{89}$ Régimen Contable Colombiano. Bogotá, 1996. p. 263.
} 
de varejo

preço de varejo"

No Peru, somente são permitidos os métodos PEPS e o Custo Médio Ponderado.

Na Venezuela, são aplicáveis os seguintes métodos: ${ }^{90}$

- M. Custo Médio: dividido em:

Custo Médio Simples

Custo Médio Ponderado

Custo Médio Móvel

- M. PEPS

- M. UEPS

- M. de Identificação Específica.

10) Sistema de estoques:

No Brasil, o registro permanente de estoques é exigido pela legislação de Imposto de Renda segundo o Parecer Normativo CST $n^{0} 6$, de 26/1/79. Mas se a empresa não mantiver tal registro, também é aceita uma forma alternativa de contagem física, onde os estoques são valorados de acordo com os preços mais recentes.

${ }^{90}$ CARPIO, Fernando Catacora. Op. Citada. Caracas, 1999. 
Na Colômbia," "para a determinação do Imposto sobre a Renda somente são permitidos o estoque permanente ou contínuo, ou outro sistema de reconhecido valor técnico, mas não o conjunto de estoques".

\section{1) Classificação dos estoques:}

Outra diferença é que na Colômbia, na Argentina, na Venezuela e no Peru os estoques são considerados itens não monetários. No Brasil, os estoques são considerados itens monetários e, portanto, não foram corrigidos de acordo com a Lei 6.404/76.

12) Correção monetária dos estoques:

Os estoques não são corrigidos pela inflação na Argentina, Brasil e Colômbia. Os estoques são corrigidos pela inflação no Peru e na Venezuela.

\footnotetext{
${ }^{91}$ Régimen Contable Colombiano. Bogotá, 1996. p. 263 - 285.
} 
ESTOQUES

Normas Contábeis

Mercadorias, Produtos Acabados, Produtos em elaboração, Matérias primas, almoxarifado, etc.

\begin{tabular}{|l|l|l|l|l|}
\hline \multicolumn{1}{|c|}{ ARGENTINA } & \multicolumn{1}{|c|}{ BRASIL } & \multicolumn{1}{c|}{ COLÔMBIA } & \multicolumn{1}{c|}{ PERU } & \multicolumn{1}{c|}{ VENEZUELA } \\
\hline $\begin{array}{l}\text { Custo de Reposição } \\
\text { Custo Histórico }\end{array}$ & $\begin{array}{l}\text { Custo Histórico ou } \\
\text { Valor de Mercado, o } \\
\text { menor } \\
\text { Ibracon: Custo ou Valor } \\
\text { Líquido de Realização, } \\
\text { (VLR), o menor }\end{array}$ & $\begin{array}{l}\text { Custo Histórico ou } \\
\text { Valor Líquido Realizável, } \\
\text { o menor }\end{array}$ & $\begin{array}{l}\text { Custo Histórico } \\
\text { Custo Corrigido ou } \\
\text { Valor do Mercado (VLR) } \\
\text { o menor }\end{array}$ & $\begin{array}{l}\text { Custo Histórico } \\
\text { Custo Corrigido ou } \\
\text { Valor recuperável, o } \\
\text { menor } \\
\text { - VLR } \\
\text { - Valor de uso }\end{array}$ \\
\hline
\end{tabular}

\section{Fisco}

Mercadorias, Produtos Acabados, Produtos em elaboração, Matérias primas, almoxarifado, etc.

\begin{tabular}{|c|c|c|c|c|}
\hline ARGENTINA & BRASIL & COLÔMBIA & PERU & VENEZUELA \\
\hline $\begin{array}{l}\text { Custo de Aquisição } \\
\text { Método: } \\
\text { UEPS ou LIFO }\end{array}$ & $\begin{array}{l}\text { Custo de Aquisição } \\
\text { Métodos: } \\
\text { Custo Médio } \\
\text { PEPS ou FIFO }\end{array}$ & $\begin{array}{l}\text { Custo Histórico } \\
\text { Valor Líq. de Realização, } \\
\text { o menor } \\
\text { Métodos: Custo médio } \\
\text { ponderado } \\
\text { PEPS } \\
\text { UEPS } \\
\text { de Identificação } \\
\text { Específica } \\
\text { Outros }\end{array}$ & $\begin{array}{l}\text { Custo Histórico } \\
\text { Custo Corrigido ou } \\
\text { Custo de Reposição, o } \\
\text { menor } \\
\text { Método: } \\
\quad \text { Custo médio } \\
\text { PEPS ou FIFO }\end{array}$ & \begin{tabular}{|l} 
Custo Histórico \\
Custo Corrigido ou \\
Valor recuperável, o \\
menor \\
Mét.: Custo médio \\
PEPS ou FIFO \\
UEPS ou LIFO \\
Identificação \\
específica
\end{tabular} \\
\hline
\end{tabular}




\begin{tabular}{|l|l|l|l|l|}
\hline \multicolumn{4}{|c|}{ Bens Fungíveis } \\
\hline \multicolumn{1}{|c|}{ ARGENTINA } & \multicolumn{1}{|c|}{ BRASIL } & \multicolumn{1}{c|}{ COLÔMBIA } & \multicolumn{1}{c|}{ PERU } & \multicolumn{1}{c|}{ VENEZUELA } \\
\hline $\begin{array}{l}\text { Valor Líquido de } \\
\text { Realização }\end{array}$ & Valor de Mercado & $\begin{array}{l}\text { Critério não previsto } \\
\text { nas normas }\end{array}$ & $\begin{array}{l}\text { Critério não previsto } \\
\text { nas normas }\end{array}$ & $\begin{array}{l}\text { Critério não previsto } \\
\text { nas normas }\end{array}$ \\
\hline
\end{tabular}

\begin{tabular}{|c|c|c|c|c|}
\hline \multicolumn{5}{|c|}{ Produtos agrícolas, animais e Extrativos } \\
\hline ARGENTINA & BRASIL & COLÔMBIA & PERU & VENEZUELA \\
\hline $\begin{array}{l}\text { Valor Líquido de } \\
\text { Realização }\end{array}$ & $\begin{array}{l}\text { Valor de Mercado } \\
\text { a) atividade seja } \\
\text { primária } \\
\text { b) Que o custo de } \\
\text { produção seja de } \\
\text { seja de difícil } \\
\text { determinação } \\
\text { c) Efetivo mercado } \\
\text { que possibilite } \\
\text { a liquidez imediata }\end{array}$ & $\begin{array}{l}\text { Nas plantações agrícolas } \\
\text { utiliza-se E. Permanente } \\
\text { Amortização depende de } \\
\text { seu ciclo agronômico }\end{array}$ & $\begin{array}{l}\text { Critério não previsto } \\
\text { nas normas }\end{array}$ & $\begin{array}{l}\text { Critério não previsto } \\
\text { nas normas }\end{array}$ \\
\hline
\end{tabular}

\begin{tabular}{|l|l|l|l|l|}
\hline \multicolumn{5}{|c|}{ Estoques em Produço ou Construção que se prolongue no tempo } \\
\hline \multicolumn{1}{|c|}{ ARGENTINA } & \multicolumn{1}{|c|}{ BRASIL } & \multicolumn{1}{c|}{ COLÔMBIA } & \multicolumn{1}{c|}{ PERU } & \multicolumn{1}{c|}{ VENEZUELA } \\
\hline $\begin{array}{l}\text { Valor Líquido de } \\
\text { Realização }\end{array}$ & $\begin{array}{l}\text { Custo Histórico ou } \\
\text { V. de Mercado, o menor }\end{array}$ & $\begin{array}{l}\text { Critério não previsto } \\
\text { nas normas }\end{array}$ & $\begin{array}{l}\text { Critério não previsto } \\
\text { nas normas }\end{array}$ & $\begin{array}{l}\text { Critério não previsto } \\
\text { nas normas }\end{array}$ \\
\hline
\end{tabular}

\begin{tabular}{|l|l|l|l|l|}
\hline \multicolumn{1}{|c|}{ ARGENTINA } & \multicolumn{1}{|c|}{ BRASIL } & \multicolumn{1}{c|}{ COLÔMBIA } & \multicolumn{1}{c|}{ PERU } & VENEZUELA \\
\hline $\begin{array}{l}\text { Critério não previsto } \\
\text { nas normas }\end{array}$ & $\begin{array}{l}\text { Valor Líquido de } \\
\text { Realização }\end{array}$ & $\begin{array}{l}\text { Critério não previsto } \\
\text { nas normas }\end{array}$ & $\begin{array}{l}\text { Critério não previsto } \\
\text { nas normas }\end{array}$ & $\begin{array}{l}\text { Critério não previsto } \\
\text { nas normas }\end{array}$ \\
\hline
\end{tabular}




\subsection{2.- CONCLUSÕES SOBRE OS INVESTIMENTOS PERMANENTES}

1) Aplicação do Método da Equivalência Patrimonial:

A diferença fundamental está na aplicação ou não do Método da Equivalência Patrimonial (MEP).

Na Argentina, de acordo com a RT no $19,{ }^{92}$ a aplicação do Método de Valor Patrimonial Proporcional depende de:

${ }^{92}$ http://www.facpce.com.ar 
1. Controle: possuir mais de $50 \%$ dos votos possíveis, direta ou indiretamente, na data de encerramento do exercício da sociedade controladora.

2. Controle conjunto: Compartilhamento de decisões entre os sócios.

3. Influência significativa:

- por possuir uma quantidade de votos para influir na aprovação das demonstrações contábeis e na distribuição de lucros;

- representação na diretoria;

- participação na fixação de políticas;

- $\quad$ intercâmbio de executivos em nível de direção;

- dependência técnica de uma das sociedades em relação á outra.

Quando não cumpram com estes requisitos, os investimentos serão avaliados pelo custo.

No Brasil, o Método da Equivalência patrimonial é aplicado :

- nos investimentos em controladas;

- nos investimentos relevantes em coligadas;

- Se o investimento é relevante, é necessário verificar também 
- $\quad$ se a investidora tem influência na administração da coligada

- $\quad$ se a porcentagem de participação da investidora representa $20 \%$ ou mais do capital social da coligada.

- De acordo com o $\mathrm{IOB},{ }^{93}$ no caso das instituições financeiras autorizadas a funcionar pelo Banco Central, e no caso da companhia aberta ter controladas e coligadas, pode ocorrer o seguinte: Quando são controladas, elas devem ser obrigatoriamente avaliadas pelo Método da Equivalência Patrimonial.

No caso das coligadas, quando o conjunto seja relevante e o investidor seja fiscalizado pelo Banco Central, é possível que as coligadas possam utilizar o Método da Equivalência Patrimonial. Quando for o caso das companhias abertas a CVM, dispõe que não somente é necessário que o conjunto das coligadas seja relevante, mas devem também cumprir com as duas condições: o mínimo de 20 \% de participação ou ter influência significativa.

No caso que o conjunto não seja relevante e somente uma companhia seja relevante, se esta for controlada tem obrigação de utilizar o MEP, mas se é coligada deve-se 
saber se cumpre com as duas condições: o mínimo de $20 \%$ de participação ou ter influência significativa. Este último caso se aplica para as companhias fiscalizadas pela CVM e pelo Banco Central.

Na Colômbia, de acordo com o artigo 61 do Decreto 2649 de $1993^{94}$, os investimentos que devem ser avaliados pelo Método de participação são os investimentos diretos em filiais nas seguintes condições:

- $\quad$ "A principal tenha o poder de dispor que no período seguinte a empresa filial distribua a ela seus lucros.

- A principal não tenha a intenção de vender o investimento no futuro imediato.

- A filial não tenha nenhuma restrição para a distribuição de seus lucros".

São subordinadas as empresas que cumprem as seguintes condições:

- Quando a empresa investidora tem $50 \%$ ou mais do capital votante da investida, seja direta ou indiretamente.

\footnotetext{
${ }^{93}$ IOB. Temática Contábil e Balanços. Quais Investimentos devem ser avaliados pela Equivalência Patrimonial? (1 parte).1 Semana - Outubro de 1999 - N 40. p. 1 - 9.

${ }^{94}$ Régimen Contable Colombiano. Bogotá. P. 212-236.
} 
- Quando é possível que a investidora junto com suas subordinadas possam formar o quorum mínimo ou tenham a possibilidade de eleger o maior número de pessoas na junta diretiva.

- Quando possa exercer influência dominante nas decissões.

No Peru, são aceitas as normas do IASC, mas para fins tributários somente é aceito o método do custo. O limite dos investimentos permanentes para empresas sem cotação na bolsa de valores é o menor entre o custo ajustado por inflação ou o valor de participação patrimonial.

A aplicação do Método da Equivalência Patrimonial no Peru é realizada:

a) Nos investimentos em filiais ou subsidiárias (controladas)

b) Nos investimentos em afiliadas ou associadas (coligadas):

- Quando se tem influência significativa devido a que direta ou indiretamente em conjunto com outras empresas ou filiadas possui-se $20 \%$ ou mais dos direitos de voto 
- Quando se tem influência significativa, sem possuir $20 \%$ ou mais dos direitos de voto, mas quando essa faculdade pode ser claramente demonstrada.

Na Venezuela, aplica-se o método de Participação Patrimonial quando a empresa investidora tenha influência significativa mas não controle (entre $20 \%$ e $50 \%$ das ações).

\section{2) Classificação dos Investimentos Permanentes:}

Na Argentina, os Investimentos Permanentes são registrados no Ativo não Corrente em Investimentos a Longo Prazo.

No Brasil, os Investimentos Permanentes são registrados no Ativo Permanente.

Na Colômbia, no Peru e na Venezuela os Investimentos Permanentes estão registrados no Ativo não Corrente.

\section{3) Relevância:}

Na relevância dos investimentos encontramos que:

$\mathrm{Na}$ Argentina existe $\mathrm{o}$ conceito de influência significativa determinada de acordo com algumas condições, mas não dá 
porcentagens de mensuração como no caso do investimento relevante que existe no Brasil.

$\mathrm{Na}$ Argentina não se menciona tampouco do conjunto de investimentos relevantes que o Brasil especifica.

No Brasil, o conceito de relevância está definido no Art. 247 da Lei das Sociedades por Ações:

"Parágrafo único - Considera-se relevante o investimento:

a) em cada sociedade coligada ou controlada, se o valor contábil é igual ou superior a 10\% (dez por cento) do valor do patrimônio líquido da companhia;

b) no conjunto das sociedades coligadas e controladas, se 0 valor contábil é igual ou superior a 15\% (quinze por cento) do valor do patrimônio líquido da companhia." 95

Na Colômbia se menciona a influência dominante, mas não se estabelecem porcentagens dessa influência. Não existe tampouco o caso de conjunto de investimentos relevante.

No Peru, se indica o $20 \%$ ou mais do capital votante e de influência significativa que pode ser demonstrada para a

\footnotetext{
${ }^{95}$ Lei N 6.404 de 15/12/76 alterada pela Lei n 9.457 de 5/5/97. Brasília, 1997.p. 285-287.
} 
utilização do MEP. Não se menciona o conjunto relevante de investimentos.

$\mathrm{Na}$ Venezuela, encontramos que é necessário ter influência significativa, mas não controle, e dá porcentagens entre $20 \%$ e $50 \%$ das ações. Tampouco se menciona o conjunto relevante de investimentos.

\section{4) Conceitos de Controladas e Coligadas}

$\mathrm{Na}$ Argentina, as empresas controladas são aquelas que a investidora possui $50 \%$ ou mais do capital votante. As empresas coligadas são aquelas que a investidora possui influência significativa, mas não dá porcentagens.

No Brasil, os conceitos de coligadas e controladas são explicitados no artigo 243 da Lei das Sociedades por Ações: ${ }^{96}$

"Considera-se controlada a sociedade na qual a controladora, diretamente ou através de outras controladas, é titular de direitos de sócio que the assegurem, de modo permanente, preponderância nas deliberações sociais e o poder de eleger a maioria dos administradores".

\footnotetext{
${ }^{96}$ Lei N 6.404 de 15/12/76 alterada pela Lei n 9.457 de 5/5/97. Brasília, 1997.p. 285-287
} 
"São coligadas as sociedades quando uma participa, com 10\% (dez por cento) ou mais, do capital da outra, sem controlá-la".

$\mathrm{Na}$ Colômbia, considera-se controlada quando a principal possui mais de $50 \%$ da subordinada, diretamente ou através de suas subordinadas ou das subordinadas destas. Não se consideram as ações sem direito a voto.

As coligadas seriam aquelas onde a principal tenha influência dominante de acordo com algumas condições. Mas não dá porcentagens.

No Peru existem os investimentos em Filiais ou Subsidiárias (controladas) quando a empresa investidora tem direta ou indiretamente mais da metade do capital votante.

Também existem os investimentos em afiliadas (coligadas) quando a empresa investidora tem influência significativa ou $20 \%$ do capital votante.

$\mathrm{Na}$ Venezuela existe coligadas onde se possui influência significativa mas não controle. Essa influência significativa deve ser entre $20 \%$ e $50 \%$ do capital votante. 


\section{5) Data de apresentação das Demonstrações Financeiras:}

$\mathrm{Na}$ Argentina, as empresas investidas devem apresentar suas demonstrações contábeis na mesma data que a principal, mas existe a possibilidade que as empresas investidas possam apresentar suas demonstrações contábeis para a aplicação do MEP com diferença de três meses anteriores à data de fechamento da investidora. Isto não é válido para as companhias abertas fiscalizadas pela Comissão Nacional de Valores, que não aceita defasagem nas datas de fechamento.

No Brasil, a Lei das Sociedades por Ações dá um prazo de 60 dias no máximo para a apresentação dos Balanços das investidas, antes da data do balanço da investidora.

Na Colômbia, as empresas investidas devem apresentar suas Demonstrações contábeis na mesma data que a principal.

No Peru e na Venezuela, as Demonstrações contábeis devem ser apresentadas na mesma data. Não se encontrou informação sobre outra data.

\section{6) Recomendações do IASC:}


O Comitê de Normas Contábeis e Internacionais (IASC) procura homogenizar as práticas contábeis e recomenda o uso da equivalência patrimonial sobre os investimentos nos quais se tenha $20 \%$ ou mais do capital votante ou sobre os quais se tenha influência.

A equivalência deve ser feita de forma a produzir o mesmo lucro líquido e o mesmo patrimônio líquido na investidora que produziria caso efetuasse a consolidação dessas investidas. 
4.3.3.- CONCLUSÕES SOBRE O IMOBILIZADO 


\section{1) Avaliação do Ativo Imobilizado:}

Na avaliação do Ativo Imobilizado encontramos que:

Na Argentina, utilizam-se valores correntes. Não obstante, se esse critério tem dificuldades práticas pela não disponibilidade de tais valores, recomenda-se o uso do critério do custo original corrigido por índice específico.

A RT nำ17, que vai entrar em vigência no 2001, dá como critérios de avaliação do imobilizado: seu custo histórico menos as depreciações.

No Brasil, a avaliação é ao custo de aquisição deduzido da depreciação, pelo desgaste ou perda de utilidade ou amortização ou exaustão. Em certas circunstâncias é admitida a reavaliação de ativos.

Na Colômbia, no final do período, o valor líquido destes ativos ajustados pela inflação deve ser ajustado a seu valor de realização ou a seu valor atual ou a seu valor presente, o mais apropriado nas circunstâncias, registrando as provisões ou valorizações necessárias. Podem ser excetuados desta disposição aqueles ativos cujo valor ajustado seja inferior a vinte salários mínimos mensais. 
No Peru, o valor ajustado dos imóveis, maquinaria e equipamentos não deve exceder ao valor que a empresa pode recuperar do uso futuro deste ativo, valor de utilização econômica ou de taxação independente.

Na Venezuela existe o critério de o menor entre o custo corrigido ou o Valor recuperável futuro. Este último pode ser o Valor de Realização líquido ou o Valor de uso.

O custo de aquisição compreende as despesas incorridas para colocar o ativo em condições para ser usado. Compreende também a capitalização de juros.

Somente podem capitalizar-se como ativo fixo a parcela de juros que excede à taxa de inflação, geralmente denominada taxa real de juros. Este procedimento é aplicável inclusive nos períodos de construção ou instalação prévios à colocação em atividade dos ativos.

Ativos que classificam para capitalização de juros:

a) Ativos que são construídos ou de outra maneira produzidos para ser usados pela própria empresa (incluindo ativos construídos ou produzidos para a empresa por outros, efetuando-se depósitos ou pagamentos para eles no decorrer da construção). 
A CVM recomenda que, no Brasil, as empresas de capital aberto também capitalizem juros na fase pré-operacional.

b) Ativos para a venda ou arrendamento que são construídos ou de outra maneira fabricados em processos não repetitivos. (Exemplo: barcos).

Os juros não serão capitalizados para os seguintes tipos de ativos:

a) Ativos cuja construção foi concluída e que estão incorporados ou preparados para ser usados nas atividades rentáveis da empresa.

b) Ativos que não estão se utilizando nas atividades normais da empresa e que não estão submetidos às atividades necessárias para sua preparação.

\section{2) Critérios sobre Reavaliação:}

Nos critérios sobre Reavaliação encontramos que:

Na Argentina, o Ativo Imobilizado pode ser reavaliado segundo as normas contábeis e fiscais, e a contrapartida da reavaliação é contabilizada diretamente na conta de resultado. Não obstante a Comissão Nacional de Valores não admite a contabilização de reavaliação para as companhias de capital aberto. 
No Brasil, a Lei n 6.404/76 fala sobre Reavaliação de todos os elementos do ativo, não obstante o Ibracon, a CVM e o Regulamento do Imposto de Renda aceitam as reavaliações somente para o Imobilizado. O crédito é feito em conta de Patrimônio Líquido (Reserva de Reavaliação).

Na Colômbia, o valor de realização, atual ou presente destes ativos deve ser determinado no final do período onde foram adquiridos ou formados e no mínimo cada três anos, mediante reavaliações praticadas por pessoas naturais, vinculadas ou não à entidade econômica, ou por pessoas jurídicas, de comprovada idoneidade profissional, solvência moral, experiência e independência.

No Peru a reavaliação é opcional.

Na Venezuela, o Ativo Fixo somente pode ser reavaliado no Método Integral Misto, ou seja, corrigir os itens pelo NGP - Nível Geral de Preçõs e depois aplicar a reavaliação.

A Reavaliação dos itens não monetários dentro do Método Misto pode-se fazer dentro de uma das seguintes alternativas:
a) Todo o Ativo Fixo
b) Todo o Ativo Fixo e os estoques 
3) Na composição do Ativo Imobilizado encontramos que:

Na Argentina, o Ativo Imobilizado é composto somente pelos bens tangíveis, utilizando um grupo diferente para os bens intangíveis.

O Brasil discorda dos outros países devido a que considera como Imobilizado os bens tangíveis e intangíveis.

Os bens tangíveis considerados são os edifícios, maquinaria, equipamentos, etc.

Os bens intangíveis considerados são as marcas, patentes, etc.

De acordo com a NPC $7^{97}$, o Ativo Imobilizado compreende os ativos tangíveis que são mantidos para uso na produção ou fornecimento de mercadorias ou serviços, para locação a terceiros, ou para finalidades administrativas; e que deverão ser usados por mais de um período. Esta norma não menciona os ativos intangíveis.

Na Colômbia, o Ativo Imobilizado somente compreende os bens tangíveis, mas tem outro grupo para o Ativo Intangível.

No Peru, o Ativo Imobilizado é composto somente pelos bens tangíveis, e utiliza outro grupo para o Ativo Intangível. 
Na Venezuela, há dois grupos, um para o Ativo Fixo Tangível e outro para o Ativo Fixo Intangível.

\section{4) Classificação do Ativo Imobilizado:}

Somente o Brasil discorda dos outros países, classificando o Ativo Imobilizado no Ativo Permanente. Os outros países estudados classificam o Ativo Imobilizado no Ativo não Corrente.

Nas normas do IAS 16 e 23 encontramos que:

"Imobilizações devem ser registradas pelo custo histórico (tratamento recomendado).

Os custos de financiamento atribuíveis diretamente à construção de imobilizado são capitalizados.

Como um tratamento alternativo, a reavaliação do imobilizado é permitida. Se um ativo for reavaliado, a categoria inteira dos ativos deve ser reavaliada. As reavaliações devem ser atualizadas regularmente.

Os superávits de reavaliação são creditados a uma reserva de reavaliação, a menos que estes revertam uma deficiência previamente debitada na demonstração de resultados.

As deficiências são registradas no resultado a menos que revertam um superávit previamente gerado pelo mesmo ativo. O cálculo da deficiência é na base de item por item.

Ao baixar um ativo reavaliado, o superávit da reavaliação é transferido para lucros acumulados “. 98

${ }^{97}$ IBRACON. NPC 7 Ativo Imobilizado. Brasil, janeiro 2001.

${ }^{98}$ CFC. Contabilidade no contexto internacional - 9. São Paulo, 1997. 


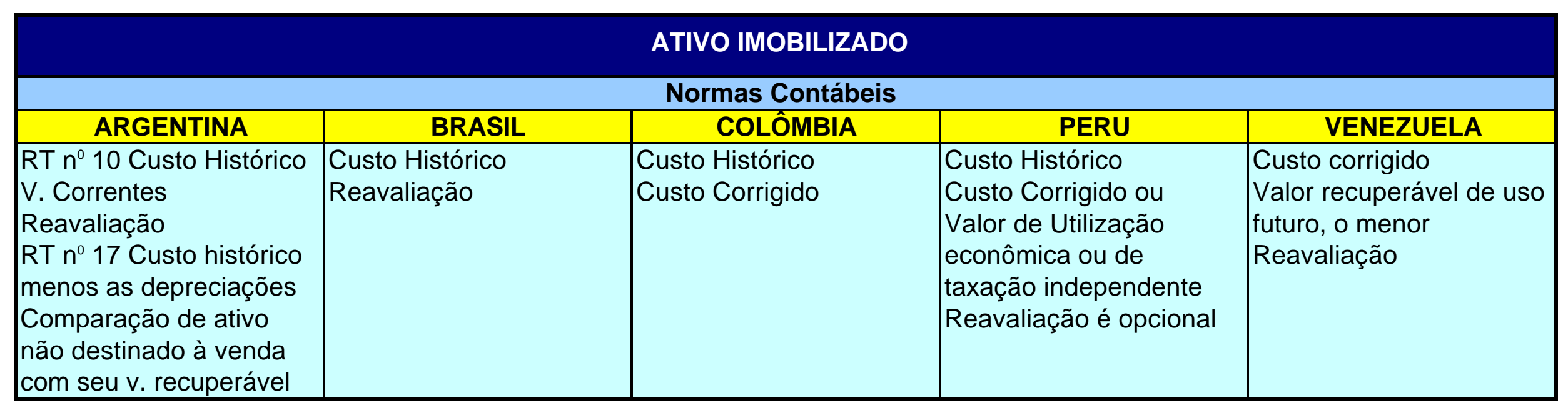

\begin{tabular}{|c|c|c|c|c|}
\hline \multicolumn{5}{|c|}{ Fisco } \\
\hline ARGENTINA & BRASIL & COLÔMBIA & PERU & VENEZUELA \\
\hline $\begin{array}{l}\text { Custo Histórico } \\
\text { A CVN não permite } \\
\text { reavaliações }\end{array}$ & $\begin{array}{l}\text { Custo Histórico } \\
\text { Reavaliação }\end{array}$ & $\begin{array}{l}\text { Custo Histórico } \\
\text { Custo Corrigido ajust. a } \\
\text { Valor de Realização ou } \\
\text { Valor atual ou Valor } \\
\text { Presente através de } \\
\text { Reavaliações } \\
\text { Exceto V. ajust < } 20 \text { s.m. }\end{array}$ & $\begin{array}{l}\text { Custo Histórico } \\
\text { Custo Corrigido ou } \\
\text { Valor de Utilização } \\
\text { econômica ou de } \\
\text { taxação independente } \\
\text { Reavaliação é opcional }\end{array}$ & Não há referência \\
\hline
\end{tabular}




\subsection{4.- CONCLUSÕES SOBRE O LEASING OU O ARRENDAMENTO MERCANTIL}

1) Diferenciação entre o Leasing Financeiro e o Leasing

\section{Operacional:}

$\mathrm{Na}$ Argentina,${ }^{99}$ o tratamento do leasing financeiro é como uma compra com financiamento e fazendo parte de seu ativo, depreciados de acordo com as normas gerais que regem as empresas. E no caso de leasing operacional, os débitos devem ser registrados como despesa de aluguel para o período contábil.

No Brasil, o leasing ${ }^{100}$ é considerado como um aluguel normal, isto significa que o bem que se recebe não é ativado, tampouco são registrados no passivo exigível o compromisso de pagamento das prestações, ditas prestações são registradas como despesas e quando chegar o final de contrato existe a opção para o arrendatário de ficar com o bem ou devolver. Se optar por ficar com o bem, pode colocá-lo no seu ativo de acordo com o contrato, pelo valor residual (se relevante).

\footnotetext{
${ }^{99} \mathrm{http}: / / \mathrm{www}$. facpce.com.ar

${ }^{100}$ IOB. Temática Contábil e Balanços. Arrendamento mercantil (leasing) Contabilização na arrendatária. Brasil. 1999.
} 
O Conselho Monetário Nacional definiu novas normas para as arrendadoras através da Resolução nำ2.309, de 28.08.96 do Banco Central do Brasil, emendada pela de n² 2.465, de 19.02.98. Através destas normas, as operações de arrendamento mercantil foram classificadas em dois grupos: arrendamentos mercantis financeiros e arrendamentos mercantis operacionais. Não obstante nas arrendatárias se continua com a contabilização tanto de uma operação quanto da outra como se fossem aluguéis.

Há exceções como nas grandes companhias aéreas, as quais vêm contabilizando as operações de leasing financeiro como compra e venda financiada, e as de leasing operacional como aluguel.

Na Colômbia, os Contratos de Leasing estão normatizados pelo Artigo.127-1-Adicionado, Lei233/95.Art.88 ${ }^{101}$. No Leasing Financeiro, os arrendatários que apresentem no 31 de dezembro do ano imediatamente anterior um patrimônio bruto inferior a cinco Bilhões de pesos $(\$ 5.000 .000 .000)$ poderão, de acordo com certas regras, usar o tratamento do leasing operacional, item 1. Todos os contratos de arrendamento financeiro ou leasing com opção de compra, que se celebrem a partir do $1^{0}$ de janeiro do ano

\footnotetext{
${ }^{101}$ Régimen Contable Colombiano. Bogotá, 1996.
} 
2006, deverão submeter-se ao tratamento do leasing financeiro, como uma compra financiada, item 2.

No Peru é aceita a NIC 17 na contabilização dos arrendamentos financeiro e operacional.

De acordo com o IASC $^{102}$ existem dois tipos de arrendamento: financeiro e operacional.

No arrendamento financeiro, o tratamento é como uma venda financiada, e no arrendamento operacional, o tratamento é como um aluguel.

O objetivo do IASC é separar como arrendamentos financeiros aqueles em que se têm de fato uma caracterização de compra e venda a prazo com financiamento da empresa de arrendamento mercantil. E como arrendamento operacional aqueles em que se tem a caracterização de efetivo aluguel.

Assim se coloca o princípio da essência econômica sobre a forma jurídica.

Não obstante o anterior ${ }^{103}$, para efeitos legais, o arrendamento financeiro é considerado um arrendamento operacional, de acordo com o estabelecido pelo Decreto Legislativo № 299 e o

\footnotetext{
${ }^{102}$ IOB. Temática contábil e Balanços. Arrendamento mercantil (leasing) Contabilização na arrendatária. Brasil, 1999.
} 
regulamento Decreto Supremo N N 529-84-EFC. Estas normas dispõem que a arrendadora mantém a propriedade dos bens utilizados no arrendamento financeiro e que a empresa arrendatária deve colocar a resultados os montantes realizados. Devido a isto, primeiro se faz a contabilização de acordo com a NIC 17, e depois, para efeitos legais e tributários, se fazem os agregados e deduções necessários para a obtenção do resultado imponível para o imposto de renda.

Na Venezuela ${ }^{104}$ aplica-se a DPC-14 baseada nas normas do NIC 17 do IASC e do FAS 13.

\section{Recomendações do IASC ${ }^{105}$ :}

As normas do IASC para o arrendatário são as seguintes:

"O leasing financeiro deve ser refletido no balanço do arrendatário pelo registro de um ativo e um passivo em valores iguais no início do lease, no valor de mercado do ativo arrendado, ou, se menor, no valor presente das prestações.

As prestações do bem arrendado devem ser alocadas entre a despesa financeira e a redução do passivo. A despesa financeira deve ser alocada ao longo do termo do lease, a fim de produzir uma taxa de juros constante periódica sobre o saldo remanescente do passivo para cada período.

Um leasing financeiro gera uma despesa de depreciação para o ativo, bem como uma despesa financeira para cada período contábil. A política de depreciação para ativos arrendados deve ser consistente com a política para ativos próprios depreciáveis.

\footnotetext{
103 “Informativo Caballero Bustamante". Manual de Consultoría Contable. Lima, 1999. p.15 - 20.

${ }^{104}$ CARPIO, Fernando Catacora. Op. citada. Caracas, 1999.

${ }^{105}$ CRC. Contabilidade no contexto Internacional - 9. São Paulo, 1997. p. 45 - 47.
} 
O débito nos resultados num leasing operacional deve ser a despesa de aluguel para o período contábil".

As normas do IASC para o arrendador são as seguintes:

"Leasing financeiro: registrado no Contas a Receber considerando os pagamentos mínimos do arrendamento (somatório das parcelas) deduzidos das rendas a apropriar, que é lançada a resultado com base em uma taxa interna de retorno.

Leasing operacional: contabilizado como ativo imobilizado depreciável e os aluguéis a receber são incluídos na receita durante o prazo de arrendamento". 
ARRENDAMENTO MERCANTIL - LEASING

\begin{tabular}{|l|l|l|l|l|}
\hline \multicolumn{1}{|c|}{ ARGENTINA } & \multicolumn{1}{|c|}{ BRASIL } & \multicolumn{1}{c|}{ COLÔMBIA } & \multicolumn{1}{c|}{ PERU } & VENEZUELA \\
\hline $\begin{array}{l}\text { Há segregação entre } \\
\text { Leasing Financeiro } \\
\text { e Operacional }\end{array}$ & $\begin{array}{l}\text { Não há segregação } \\
\text { entre Leasing Financeiro } \\
\text { e Operacional }\end{array}$ & Não há referência & $\begin{array}{l}\text { Há segregação entre } \\
\text { Leasing Financeiro e } \\
\text { Operacional } \\
\text { Aceita-se a NIC 17 }\end{array}$ & $\begin{array}{l}\text { Há dois tipos de leasing } \\
\text { Financeiro e Operacional } \\
\text { Aceita-se a NIC 17 }\end{array}$ \\
\hline
\end{tabular}

\begin{tabular}{|l|l|l|l|l|}
\hline \multicolumn{1}{|c|}{ ARGENTINA } & \multicolumn{1}{|c|}{ COLÓMBIA } & \multicolumn{1}{c|}{ PERU } & \multicolumn{1}{c|}{ VENEZUELA } \\
\hline $\begin{array}{l}\text { Há segregação entre } \\
\text { Leasing Financeiro }\end{array}$ & $\begin{array}{l}\text { Há segregação entre } \\
\text { e Operacional }\end{array}$ & $\begin{array}{l}\text { Há segregação entre } \\
\text { leasing Financeiro e } \\
\text { Operacional para as } \\
\text { arrendadoras } \\
\text { No caso das arrendatárias } \\
\text { o tratamento é como } \\
\text { e Operacional mas tem } \\
\text { seus próprios critérios }\end{array}$ & $\begin{array}{l}\text { Para efeitos legais e } \\
\text { tributários, o leasing } \\
\text { financeiro é considerado } \\
\text { como um leasing } \\
\text { operacional. }\end{array}$ & Não há referência \\
& & & \\
\hline
\end{tabular}

\begin{tabular}{|l|l|l|l|l|}
\hline \multicolumn{5}{|c|}{ ATIVO DIFERIDO } \\
\hline \multicolumn{1}{|c|}{ Normas Contábeis } \\
\hline \multicolumn{1}{|c|}{ ARGENTINA } & \multicolumn{1}{|c|}{ COLÔMBIA } & \multicolumn{1}{c|}{ PERU } & VENEZUELA \\
\hline $\begin{array}{l}\text { Não existe essa } \\
\text { classificação }\end{array}$ & Custo Histórico & $\begin{array}{l}\text { Custo Histórico } \\
\text { Custo Corrigido } \\
\text { Amortizado:recuperação }\end{array}$ & $\begin{array}{l}\text { Não existe essa } \\
\text { classificação }\end{array}$ & $\begin{array}{l}\text { Custo Histórico } \\
\text { Custo Corrigido }\end{array}$ \\
\hline
\end{tabular}




\subsection{5.- CONCLUSÕES SOBRE O ATIVO DIFERIDO}

Não há harmonização do ativo diferido nos países estudados.

\section{1) Existência do Ativo Diferido:}

No Brasil, na Colômbia e na Venezuela os itens como despesas pré-operacionais, despesas de organização, despesas de pesquisa estão classificadas no Ativo Diferido.

Na Argentina e no Peru não há Ativo Diferido e esses itens fazem parte do Ativo Intangível junto com outros como patentes e marcas.

\section{2) Composição do Ativo Diferido}

No Brasil, de acordo com a Lei das Sociedades por Ações, o Ativo Diferido está composto pelos seguintes itens: 
106“As aplicações de recursos em despesas que contribuirão para a formação do resultado de mais de um exercício social, inclusive os juros pagos ou creditados aos acionistas durante o período que anteceder o início das operações sociais”.

Na Colômbia, o Ativo Diferido é definido no ART. 67 do D.R. $2649 / 93^{107}$ e é composto pelos seguintes itens:

1. Despesas antecipadas, tais como juros, seguros, arrendamentos e outros incorridos para receber no futuro serviços.

2. Despesas Diferidas, que representam bens ou serviços recebidos dos quais espera-se obter benefícios econômicos em outros períodos. Devem ser registrados como gastos diferidos os custos incorridos durante as etapas de organização, construção, instalação, montagem e colocação em atividade.

$\mathrm{Na}$ Venezuela, a DPC- $2^{108}$ estabelece os princípios de contabilidade aplicáveis para o diferimento de custos e despesas de empresas ou atividades em período de desenvolvimento em um período máximo de cinco anos.

\footnotetext{
${ }^{106}$ Lei N 6.404 de 15/12/76 alterada pela lei n 9.457 de 5/5/97. Brasília, 1997.

${ }^{107}$ Régimen Contable Colombiano. Bogotá. 1996.

${ }^{108}$ CARPIO, Fernando Catacora. Op. citada. Caracas, 1999.
} 


\section{3) Avaliação do Ativo Diferido}

No Brasil, a avaliação do Ativo Diferido, de acordo com o art. 183 da mesma Lei de Sociedades por Ações é realizada: "pelo valor do capital aplicado, deduzido do saldo das contas que registrem a sua amortização"109.

Na Colômbia e na Venezuela, a avaliação do Ativo Diferido é o custo corrigido deduzido das contas que registrem a sua amortização.

\section{4) Amortização do Ativo Diferido}

No Brasil, a amortização será realizada de acordo a Lei de Sociedades por Ações, em prazo não superior a 10 anos, a partir do início das operações normais da empresa ou quando os benefícios sejam recebidos. Será registrado como perda quando cessem as atividades a que se destinavam ou quando essas atividades não possam obter resultados.

A legislação fiscal, de acordo com o art. 327 do RIR/99, estabelece prazo mínimo de 5 anos para a amortização.

Deve ser mencionado o critério de amortização nas Notas Explicativas.

${ }^{109}$ Lei N 6.404 de 15/12/76 alterada pela lei n 9.457 de 5/5/97. Brasília, 1997. 
Na Colômbia, a amortização dos gastos diferidos tais como as despesas preliminares de instalação ou organização ou de desenvolvimento, é dedutível no imposto de renda e complementares. O tempo para dita amortização é mínimo de cinco anos, não obstante pode fazer-se em um prazo inferior se é demonstrado que pela natureza ou duração do negócio, a amortização tenha que se realizar em um período menor.

Na Venezuela, a amortização do Ativo Diferido é em um período máximo de cinco anos.

\section{5) Contabilização:}

No Brasil, o registro da amortização do Ativo Diferido será realizado contra a conta Despesas Operacionais, no custo dos produtos elaborados, devendo estar registrado na Demonstração do Resultado ou nas Notas Explicativas.

As principais exigências dos órgãos regulamentadores no Brasil para o diferido são:

- "Desdobramento, natureza e origens dos itens, bem como razoabilidade do diferimento.

- Métodos e prazos de amortização 
- Informações adicionais quando formados por empreendimentos em fase pré-operacional, como notas explicativas da composição das adições neste grupo de contas ${ }^{110}$.

Na Colômbia, os ativos diferidos reconhecem-se no início por seu valor histórico, aplicando quando for necessária a norma básica da prudência. Ademais, quando seja necessário, deve-se efetuar o ajuste que deva corresponder com relação aos itens não monetários, utilizando para isso o Porcentagem do ajuste do ano tributável - PAAG, mas se utilizará o PAAG mensal, devido a que por sua atividade devem difundir ou emitir demonstrações financeiras de períodos intermédios.

$\mathrm{Na}$ Venezuela, o tratamento contábil especial refere-se ao aspecto de capitalizar ou não certas despesas ou custos. Este tratamento contábil especial não exclui que a companhia deva emitir suas demonstrações financeiras de acordo com princípios de contabilidade geralmente aceitos, como uma empresa com operações contínuas normais.

6) Há também diferença entre as normas de Brasil, Colômbia e Venezuela com o IAS 9 que diz o seguinte:

\footnotetext{
${ }^{110}$ CRC. Contabilidade no contexto Internacional - 9. São Paulo, 1997.
} 
111 "Custos de pesquisa e desenvolvimento devem ser registrados como despesas, a menos que sejam custos de desenvolvimento de um projeto que preencha os seguintes critérios:

a) o produto/processo está definido claramente e os custos atribuíveis a ele podem ser identificados separadamente;

b) a viabilidade técnica do produto já foi demonstrada;

c) a gerência indicou sua intenção de produzir e colocar no mercado ou utilizar o produto/processo.

d) existe uma indicação clara de um mercado futuro para o produto/processo, ou, se for utilizado internamente, sua utilidade é demonstrada claramente; $e$

e) existem recursos adequados ou estes estarão disponíveis para completar o projeto e colocar o processo/produto no mercado.

Os custos de desenvolvimento diferidos devem ser limitados ao que se pode esperar recuperar em termos razoáveis das receitas futuras relacionadas, considerando os custos de desenvolvimento futuro e os custos de produção, de venda e de administração relacionados.

Os custos de desenvolvimento diferidos devem ser alocados aos períodos contábeis futuros numa base sistemática, relacionada ou com a venda ou a utilização esperada para o produto/processo ou com sua vida útil.

O saldo de custos de desenvolvimento diferidos deve ser imediatamente baixado (parcialmente ou integralmente) se deixar de existir um dos cinco critérios acima mencionados ou se o saldo, mais os custos futuros descritos acima, excederem as receitas relacionadas projetadas no futuro. Os custos de desenvolvimento diferidos baixados desta forma podem ser recapitulados se houver uma reversão de circunstâncias".

É possível observar que não há harmonização, existindo uma clara divergência nas normas do Ativo Diferido, pesquisa e desenvolvimento entre Brasil e os outros países, em sua classificação e em seu diferimento.

Pode-se observar que há países que não admitem o diferimento dessas despesas, há outros países que podem aceitar o

\footnotetext{
${ }^{111}$ CRC. Contabilidade no Contexto Internacional. São Paulo, 1997. p. 33-34.
} 
diferimento, mas somente em condições excepcionais, e há outros que aceitam colocá-los no seu ativo.

\subsection{6.- CONCLUSÕES SOBRE AS TÉCNICAS DE RECONHECIMENTO}

\section{DA INFLAÇÃO}

Nos últimos anos, uma grande maioria de países da América do Sul atravessou altos índices de inflação, por este motivo, os profissionais destes países, empresários em geral e principalmente as autoridades fiscais, realizaram esforços para controlar este fenômeno, e desenvolveram técnicas eficientes de reconhecimento da inflação que permitam mensurar de forma adequada a situação financeira das empresas e seus resultados financeiros em um marco de economia inflacionária.

\section{1) Inflação: ${ }^{112}$}
A inflação anual em Argentina em 1999 foi de 0,30\% e a acumulada em três anos foi de 1,71\%. A Federação Argentina de Conselhos Profissionais de Ciências Econômicas através do Centro de Estudos Científicos e Técnicos (CECyT) estabeleceu que o ajuste por inflação será obrigatório quando a inflação chegue a $8 \%$ anuais.

\footnotetext{
${ }^{112}$ Os índices de inflação anual e acumulada foram extraídos do site da Federação de Colégios de Contadores Públicos de Venezuela (http://www.fccpv.org) o qual menciona ter-se baseado, por sua vez, no site (http://www.financewise.com).
} 
A inflação anual em Brasil em 1999 foi de 8,0\% e a acumulada em três anos foi de $15,01 \%$.

$\mathrm{Na}$ Colômbia aplica-se o ajuste por inflação com caráter obrigatório. A inflação em 1999 foi de 15,9\% e a acumulada em três anos foi de 59,2\%.

No Peru aplicam-se as Normas Internacionais de Contabilidade e reconhece-se o efeito da inflação em níveis de um digito anual. A Superintendência Nacional de Administração Tributária (SUNAT) obriga a correção por inflação fiscal, e a Comissão Nacional Supervisora de Empresas e Valores (CONASEV) obriga a correção por inflação das demonstrações financeiras das empresas. A inflação em 1999 foi de 8,5\% e a acumulada em três anos foi de $22,49 \%$.

Na Venezuela, a inflação em 1999 foi de $20 \%$ e a acumulada em três anos foi de $114,57 \%$.

\section{2) Reconhecimento dos efeitos da Inflação}

Na Argentina e no Brasil foi eliminado o reconhecimento dos efeitos da inflação nas demonstrações contábeis. Na Colômbia, no Peru e na Venezuela continuam realizando-se os ajustes por inflação. 
Na Argentina, o Poder executivo aprovou em seu Decreto 316/95 as disposições proibindo a aceitação das Demonstrações Financeiras que contenham ajustes por inflação pelos órgãos oficiais (CNV, IGJ e outros).

Os organismos profissionais têm questionado tal Decreto por sua interferência em questões contábeis.

$\mathrm{Na}$ Argentina, o Centro de Estudos Científicos e Técnicos (CECyT) estabeleceu que o ajuste por inflação será obrigatório quando a inflação chegar a 8\% anuais.

No Brasil, a utilização da Correção Monetária do Balanço e a denominada Correção Integral foram de muita utilidade para o desenvolvimento das empresas e no controle da inflação.

Através da Lei $n^{0}$ 9.249/95, foi eliminada a obrigação da correção monetária outorgada pela Lei $n^{0} 6.404 / 76$, assim como a Correção Integral a partir de 1996.

A CVM tornou facultativa a elaboração e a divulgação das demonstrações contábeis com correção integral.

A partir de 1996 os efeitos da inflação apesar de não serem significativos, sim possuem relevância, porque os efeitos acumulados tendem a ganhar importância. 
Devido a isto em ambos países, Brasil e Argentina, as demonstrações contábeis passaram a apresentar distorções em relação aos Princípios Fundamentais de Contabilidade, que no início do Pronunciamento da CFC colocam como requisito prévio aos princípios a essência econômica sobre a forma, e neste caso a essência econômica é a correção monetária das demonstrações financeiras devido à inflação existente, que é um fato econômico real, mesmo sendo pequena, seu efeito acumulativo é importante.

Outra conseqüência importante é a distorção na apuração do imposto de renda e os dividendos calculados sobre um resultado contábil incorreto.

Na Colômbia, no Peru e na Venezuela continuam realizando-se os ajustes por inflação.

Na Colômbia, por disposições da Lei 488, a partir de 1998 foi suspensa a correção dos estoques, receitas, custos e despesas. Isto provocou distorções na sua contabilidade.

\section{3) Normas aplicadas no Reconhecimento dos efeitos por Inflação}

$\mathrm{Na}$ Argentina, a norma que descreve esses procedimentos é a "Resolução Técnica n 6". Depois o Decreto 316/95 revogou as Demonstrações Contáveis em Moeda Constante. A RT $n^{0} 19$ modificou a RT $n^{0} 6$. 
No Brasil, a Lei $n^{0}$ 6.404/76 e depois a Lei $n^{0} 1.598 / 77$ instituíram a Correção Monetária pela Lei Societária que obrigava a todas as pessoas jurídicas sujeitas à tributação do Imposto de Renda com base no Lucro Real.

A Instrução CVM nº 64/87, depois substituída pela Instrução CVM nº 191/92 instituíram a Correção Monetária Integral para as Companhias abertas.

A Lei no 9.249/95 revogou ambas técnicas.

Na Colômbia, as Leis que normam a correção monetária das Demonstrações Contábeis são o Decreto nำ 2649/93, a Lei n174/94 e seu regulamento Decreto $n^{0}-326 / 95$. A Lei $n^{0} 488$ de 1998 revogou os ajustes por inflação nos estoques, receitas, custos e despesas.

No Peru, as normas que regulamentam 0 ajuste das Demonstrações Financeiras por efeitos da inflação são as Resoluções № 2 e 3 do Conselho Normativo de Contabilidade. Estas normas obrigam, para efeitos contábeis, o ajuste integral de quatro Demonstrações Financeiras desde 1992: o Balanço Geral, a Demonstração de Resultados, a Demonstração de Mutações no Patrimônio Líquido, e a Demonstração de Fluxos de Caixa. 
O Decreto Legislativo 797 do 31.12 .95 e seu Regulamento Decreto Supremo 006-96-EF do 12.01 .96 obrigam, para efeitos tributários, somente o Ajuste por Inflação do Balanço Geral desde o exercício 1995.

Na Venezuela, a DPC-10 é a norma que regulamenta a correção monetária das Demonstrações Financeiras. Esta norma tem três Boletins de atualização.

\section{4) Índices aplicados}

Na Argentina, o Índice aplicado para medir a inflação é o "Índice de Preços por Atacado - Nível Geral” publicado mensalmente pelo "Instituto Nacional de Estatística e Censos".

De acordo com a RT $n^{0} 19$ que modificou a RT $n^{0} 6$ o índice resultará de misturar:

a) as mensurações do índice de preços de atacado (IPM) do Instituto Nacional de Estatística e Censos até o 31 de dezembro de 1995; e

b) as mensurações do índice de preços internos por atacado (IPIM) do mesmo organismo posteriores a essa data. 
No Brasil, quando era aplicado o Método da Correção Monetária da Lei Societária foram utilizados vários índices, sendo o último a UFIR (Unidade Fiscal de Referência).

No Brasil, a Instrução CVM nº 191/92 instituiu a Unidade Monetária Contábil (UMC) como unidade de referência a ser utilizada pelas companhias abertas para elaboração de demonstrações contábeis em moeda de capacidade aquisitiva constante.

No Brasil, na atualidade são usados os seguintes indexadores ${ }^{113}$ :

- IGP / FGV: Índice Geral de Preços da Fundação Getulio Vargas Composto por 3 índices:

a) İndice de Preços por Atacado (IPA) que representa 60\% da taxa geral e que registra os aumentos de 431 produtos no mercado atacadista, em pesquisa que inclui dez mil cotações mensais.

b) Índice de Preços ao Consumidor (IPC), que pesa 30\% no geral e apura a inflação de famílias que ganham na faixa de 1 a 33 salários mínimos, através de pesquisas de 45000 preços de 388 produtos, no Rio de Janeiro e em São Paulo

c) Índice nacional do custo da construção (INCC), com peso de $10 \%$.

O IGP é calculado no período entre os dias 1 a 30 do mês em referência e divulgado por volta do dia 10.

- IGP-M / FGV: Índice Geral dos Preços - Mercado

Também calculado pela FGV. Difere do IGP no período de coleta de preços que é feita do dia 21 do mês anterior ao dia 20 do mês de referência, sendo divulgado no dia 30. É utilizado por todo o mercado financeiro.

- IPC / FIPE: Índice de Preços ao Consumidor da FIPE

Reflete a variação de preços apenas em São Paulo, baseado nas despesas de família que ganham de 2 a 6 salários mínimos. Não incluí bens duráveis. É divulgado semanalmente: compara o período quadrisemanal a cada semana.

\footnotetext{
${ }^{113}$ http://vitrine.com.br/dinheiro/, em janeiro/2001.
} 
Sua estrutura é composta por 260 produtos, a partir de uma pesquisa mensal de 51 mil preços.

- ICV / DIESSE: Índice de custo de vida/ DIEESE

Também reflete a variação de preços em São Paulo mas com base em famílias com renda mensal entre 1 e 30 salários mínimos. Pesquisado entre os dias primeiro e trinta do mês de referência.

Na Colômbia, é utilizado o "Índice de Preços ao consumidor (IPC60)" calculado pelo DANE, Departamento Administrativo Nacional de Estatística.

Utiliza-se como indicador a "Porcentagem do Ajuste do ano Tributável" (PAAG)" que pode ser anual, mensal, ou mensal acumulado. É equivalente à variação percentual do IPC pra rendas médias, calculado pelo DANE.

Outros indicadores são a taxa de câmbio, a cotização da UPAC (Unidade de Poder Aquisitivo Constante), o Pacto Especial de Reajuste e as valorizações de imóveis, etc.

No Peru, o indicador para medir a inflação é o "Índice de Preços Médio Mensal por Atacado em nível nacional” publicado no jornal "El Peruano", em forma mensal.

Na Venezuela, o Índice que mensura a inflação é o IPC, "Índice Geral de Preços em nível do Consumidor", calculado pelo Banco Central da Venezuela, mensura mensalmente o crescimento dos preços na área metropolitana de Caracas. 


\section{5) Metodologia aplicada no Reconhecimento dos efeitos da}

\section{Inflação}

Na Argentina, pelo Método de Correção Monetária, todas as demonstrações contábeis deviam expressar-se em moeda constante, definida como sendo a de encerramento do período. A correção era Integral e eram corrigidas as contas não monetárias.

Para determinação do resultado do período, era adotado o conceito de manutenção do capital financeiro, enfoque que considera capital, o total dos pesos investidos pelos sócios ou acionistas, medidos em moeda constante.

O processo de elaboração era o seguinte: ${ }^{114}$

- "Atualizar o patrimônio líquido no início do exercício em moeda de encerramento do exercício, agregando ou deduzindo em moeda de encerramento do exercício as adições ou retiradas dos proprietários.

- Determinar o patrimônio líquido no encerramento do exercício, pela diferença entre o ativo e o passivo avaliado de acordo com critérios vigentes.

- Determinar o resultado final do exercício por diferença entre os patrimônios líquidos calculados precedentemente.

- Determinar o resultado final do período, excluído o resultado por exposição à inflação mediante a atualização das parcelas que compõem a demonstração de resultado.

- Determinar o resultado por exposição à inflação por diferença entre os cálculos realizados”.

${ }^{114}$ CRC. Contabilidade no Contexto Internacional - 9. São Paulo, 1997. p. 143. 
De acordo com a RT $n^{0} 19$, que modificou a RT $n^{0} 6$, todas as demonstrações contábeis devem estar em moeda homogênea.

Na DRE todos seus itens se expõem em moeda de fechamento, líquidos da parcela realizada dos componentes financeiros implícitos nas operações.

O Resultado por exposição à mudança no poder aquisitivo da moeda, compreenderá o efeito dessa mudança sobre as partidas monetárias.

No Brasil, pelo Método da Correção Monetária pela Lei Societária, somente eram corrigidos o ativo permanente e o patrimônio líquido. Também eram corrigidas outras contas como:

a) “imóveis não classificados no ativo permanente;

b) aplicações em ouro;

c) adiantamentos a fornecedores de bens sujeitos a correção monetária;

d) aplicações em consórcios;

e) adiantamentos para futuro aumento de capital" ${ }^{115}$.

Continuam não sendo corrigidos outros ativos não monetários como Estoques, despesas antecipadas do ativo circulante e do

\footnotetext{
${ }^{115}$ Iudícibus, Martins e Gelbcke. Manual de Contabilidade das Sociedades por Ações. São Paulo, 2000. p. 443.
} 
realizável em longo prazo, investimentos temporários, adiantamento de clientes, etc.

116“"No Brasil, o sistema de Correção Integral atualiza todos os valores históricos das demonstrações contábeis para uma única data, mantendo-se, portanto, o Princípio de Custo Original como Base de Valor.

No Brasil, pelo Método da Correção Monetária Integral, temos as seguintes vantagens:

a) apresenta os efeitos da inflação em todos os elementos das demonstrações contábeis;

b) corrige saldos finais de itens não monetários (como estoques e despesas antecipadas).

c) determina a inclusão do ajuste a valor presente nos valores prefixados de contas a receber e a pagar".

Na Colômbia, pelo Método Colombiano Societário, são ajustados os itens não monetários do ativo, passivo e do Patrimônio Líquido.

A Lei $n^{0} 488$ de 1998 revogou os ajustes por inflação nos estoques, receitas, custos e despesas ${ }^{117}$.

O ajuste pode ser anual ou mensal e pode ser mensurado através do índice PAAG que pode ser anual, mensal ou mensal acumulado.

O ajuste do ativo não monetário se realiza contra a conta Correção monetária.

No ajuste do passivo são aplicados a UPAC, diferenças em câmbio e pacto de reajuste. 
O patrimônio é ajustado através da conta Revalorização do Patrimônio.

No Peru, pelo Método de Ajustes por efeitos da Inflação, são corrigidos os itens não monetários, incluídas as contas de estoques, e de resultado ${ }^{118}$.

São realizadas as seguintes etapas:

- Determinação da antiguidade;

- Cálculo do Fator de Ajuste;

- Determinação do valor atualizado através do valor em livros vezes o fator de ajuste;

- Comparação do valor atualizado com seus limites;

- O valor atualizado é registrado contra a conta Resultado pela Exposição à Inflação;

- Devem ser mostradas as demonstrações em forma comparativa de dois anos contínuos em moeda de uma data.

Na Venezuela há dois tipos de métodos para o reconhecimento da Inflação.

- O Método do Nível Geral de Preços (NGP) que ajusta integralmente as Demonstrações Contábeis de acordo com o

\footnotetext{
${ }^{116}$ Iudícibus, Martins e Gelbcke. Op. citada. São Paulo, 2000. p. 443.

${ }^{117} \mathrm{http} / / / \mathrm{www}$.incp.org.co

${ }^{118}$ IVERA Asociados. Op. citada. Lima, Perú, 1999.
} 
Índice Geral de Preços no nível de Consumidor da área metropolitana de Caracas.

- O Método Misto que primeiro ajusta as Demonstrações contábeis de acordo com o método NGP e depois substitui os valores correntes de certos ativos aos efeitos da determinação de um superávit ou déficit não realizado devido a ter ativos não monetários.

\section{6) Limite de atualização}

$\mathrm{Na}$ Argentina, os valores determinados para os diversos ativos não poderão exceder a seu valor recuperável, individualmente ou em conjunto. Valor recuperável é o maior valor obtido entre o líquido de realização e o de utilização econômica.

No Peru o limite de atualização para os valores cotados em bolsa é o menor entre o valor atualizado e o valor na bolsa no fechamento do período.

Para os valores não cotados em bolsa, o limite será o menor entre o valor atualizado e o valor de aquisição (nos investimentos temporais) ou o valor de participação patrimonial na data do ajuste nos investimentos permanentes. 
Para as antecipações a fornecedores pela compra de estoques, o limite será o menor entre o valor atualizado e o valor de reposição dos estoques.

Para os estoques, o limite será o menor entre o valor atualizado e o valor de reposição ou de mercado dos estoques.

Para os terrenos rústicos e urbanos, o limite será o menor entre o valor atualizado e o valor da tabela oficial na data do ajuste.

Para os imóveis e maquinarias, o limite será o menor entre o valor atualizado e o valor de taxação.

Para os equipamentos de cômputo e de escritório, o limite será o menor entre o valor atualizado e o valor de reposição ou de mercado.

\section{7) Resultado pela exposição à inflação}

Na Argentina, de acordo com a RT $n^{0} 6^{119}$, os itens da DRE se apresentam em moeda de fechamento, líquidos dos efeitos dos componentes financeiros implícitos nas operações. Isto significa que:

${ }^{119} \mathrm{RT} \mathrm{n}^{0} 6$ citado por Yamamoto, Marina Mitiyo. A contabilidade e o Mercosul. São Paulo, 1996. 
- "O resultado por exposição à inflação compreenda o efeito desta sobre as contas monetárias e nos sobrepreços ou coberturas de inflação, contidos implicitamente nas operações.

- Os resultados financeiros e por manutenção se expressem em termos reais".

Quando a conta Resultados financeiros e por manutenção tinha incluído também o resultado por exposição à inflação, representará a contrapartida líquida dos ajustes efetuados em todas as contas patrimoniais e de resultados, atualizada em moeda de fechamento e compreenderá:

- 120 “O resultado por exposição à inflação, entendendo por tal somente o efeito da inflação sobre as contas monetárias (ou expostas a perdas do poder aquisitivo da moeda).

- Os outros resultados por manutenção gerados no exercício ou período.

- Os resultados financeiros".

De acordo com a RT $n^{0} 19^{121}$ que modificou a RT $n^{0}$ 6: Na DRE ajustada em moeda de fechamento, esta partida se determina por

${ }^{120}$ RT n $^{0} 6$ citado por Yamamoto, Marina Mitiyo. Op. citada. São Paulo, 1996. p. 97. 
diferença entre o resultado final do período (calculado em moeda constante) e o sub-total dos itens da DRE em moeda de fechamento. Esta partida se denominará Resultados Financeiros e por posse (incluindo resultados por exposição à mudança no poder aquisitivo da moeda).

Na Colômbia, a conta de correção monetária é considerada não operacional.

No Brasil, pelo Método de Correção Monetária da Lei Societária, a conta de correção monetária é considerada não operacional.

No Peru, a conta Resultado por Exposição à Inflação também é considerada não operacional.

É o efeito da atualização de todas as partidas não monetárias e será denominado como REI, Resultado por Exposição à Inflação. É resultado do maior valor nominal atribuído ao ativo não monetário menos os maiores valores nominais atribuídos ao passivo não monetário e ao patrimônio líquido, incluem-se os valores nominais atribuídos às contas da demonstração de resultados do período a que corresponde a atualização.

\footnotetext{
${ }^{121}$ http://www.facpce.com.ar
} 
Na Venezuela, o Resultado por exposição à inflação acumulado é o ganho ou a perda acumulada na data do primeiro ajuste por inflação, o qual é transferido aos resultados acumulados de acordo com as disposições da DPC-10.

O fato de não considerar a conta de correção monetária operacional é um erro, devido a que ela é formada pelo ajuste de contas operacionais da entidade.

\section{8) Ajustes a Valor Presente}

No Brasil são realizados os ajustes a valor presente no sistema de Correção Integral em alguns itens monetários e não monetários:

122 "Os itens monetários ativos e passivos, decorrentes de operações prefixadas, devem ser traduzidos a valor presente, com base na taxa de juros vigente na data do balanço".

"Os itens não monetários, tais como estoques, imobilizados, etc., devem ser registrados pelo valor presente apurado na data de realização de cada operação. Esse registro poderá ser feito com utilização de uma conta retificadora ou diretamente por seu valor líquido".

Nos outros países não são realizados os ajustes a valor presente.

\section{9) Relevância}

\footnotetext{
${ }^{122}$ Iudícibus, Martins e Gelbcke. Op. citada. São Paulo, 2000. p. 457 e 460.
} 
As técnicas de reconhecimento da inflação de maior destaque são da Argentina, do Brasil e da Venezuela.

O sistema de Correção Integral do Brasil constitui um dos sistemas mais avançados de reconhecimento dos efeitos da Inflação por corrigir todos os elementos das demonstrações contábeis em moeda de uma data. Também por outras razões, como os ajustes a valor presente dos direitos e obrigações de operações prefixadas com base na data de juros vigente, os imobilizados apurados na data de realização de cada operação.

O sistema de correção monetária da Argentina constitui também um sistema depurado de reconhecimento da inflação.

O sistema misto de Venezuela é também um sistema importante porque mistura ambos métodos, o Nível Geral de Preços e o Método dos Custos Correntes. 


\section{TÉCNICAS DE RECONHECIMENTO DA INFLAÇÃO}

\begin{tabular}{|c|c|c|c|c|}
\hline \multicolumn{5}{|c|}{ Reconhecimento da Inflação } \\
\hline $\begin{array}{l}\text { Não há reconhecimento } \\
\text { da Inflação nas D. F. } \\
\text { Decreto } n^{0} 316 / 95 \\
\text { CECyT: } 8 \% \text { de Inflação }\end{array}$ & $\begin{array}{l}\text { Não há reconhecimento } \\
\text { da Inflação nas D. F. } \\
\text { Lei } n^{0} 9.249 / 95 \\
\text { CVM: é facultativa }\end{array}$ & $\begin{array}{l}\text { Há reconhecimento da } \\
\text { Inflação }\end{array}$ & $\begin{array}{l}\text { Há reconhecimento da } \\
\text { Inflação }\end{array}$ & $\begin{array}{l}\text { Há reconhecimento da } \\
\text { Inflação }\end{array}$ \\
\hline \multicolumn{2}{|c|}{$\begin{array}{l}\text { Leis que regulamentaram a correção monetária } \\
\text { das Demonstrações Contábeis }\end{array}$} & \multicolumn{3}{|c|}{$\begin{array}{l}\text { Leis que regulamentam a correção monetária das } \\
\text { Demonstrações Contábeis }\end{array}$} \\
\hline $\begin{array}{l}\text { Resolução Técnica } n^{0} 6 \\
\text { Resolução Técnica } n^{0} 19 \\
\text { que modificou a RT } n^{0} 6\end{array}$ & $\begin{array}{l}\text { Lei } n^{0} 6.404 / 76 \\
\text { Lei n } n^{0} 1.598 / 77 \\
\text { Instituíram a Correção } \\
\text { Monetária - Lei Societária } \\
\text { Instrução CVM n } 64 / 87 \text { e } \\
\text { Instrução CVM n } 191 / 92 \\
\text { instituíram a Correção } \\
\text { Monetária Integral para } \\
\text { companhias abertas }\end{array}$ & $\begin{array}{l}\text { Decreto } n^{0} 2649 / 93 \\
\text { Leis } 174 / 94 \text { - Decreto } \\
n^{0} 326 / 95 \\
\text { Lei } 488 \text { de } 1998\end{array}$ & $\begin{array}{l}\text { Resoluções } \mathrm{n}^{0} 2 \text { e } 3 \text { do } \\
\text { Conselho Normativo de } \\
\text { Contabilidade } \\
\text { D. Leg. N }{ }^{0} 797 / 95 \\
\text { e seu Regulamento } \\
\text { D.S. 006-96-EF. }\end{array}$ & $\begin{array}{l}\text { DPC-10 de } 1991 \text { e } \\
\text { seus três Boletins de } \\
\text { Atualização }\end{array}$ \\
\hline \multicolumn{5}{|c|}{ Índices de Inflação aplicados: } \\
\hline $\begin{array}{l}\text { "Índice de Preços de } \\
\text { Atacado - Nível Geral" } \\
\text { (IPM) até 31/12/95 } \\
\text { "İndice de Preços Inter- } \\
\text { nos de Atacado" (IPIM) } \\
\text { posteriores a essa data. }\end{array}$ & $\begin{array}{l}\text { Correção Monetária: UFIR } \\
\text { Correção Integral: Unidade } \\
\text { Monetária Contábil (UMC) } \\
\text { IGP/FGV: I. Geral dos Preços } \\
\text { IGP-M/FGV: de Mercado } \\
\text { IPC/FIPE: I.P.ao Consumidor } \\
\text { ICV/DIESSE: Custo de vida }\end{array}$ & $\begin{array}{l}\text { "Índices de Preços ao } \\
\text { Consumidor "(IPC60): } \\
\text { "(PAAG) Porcentagem } \\
\text { do ajuste do ano } \\
\text { Tributável" } \\
\text { UPAC, Pacto de Reajus } \\
\text { te, diferença de câmbio. }\end{array}$ & $\begin{array}{l}\text { "Índices de Preços } \\
\text { Médio Mensal de } \\
\text { Atacado em nível } \\
\text { Nacional" (IPM) }\end{array}$ & $\begin{array}{l}\text { "Índice Geral de } \\
\text { Preços em nível de } \\
\text { Consumidor" (IPC) }\end{array}$ \\
\hline
\end{tabular}


TÉCNICAS DE RECONHECIMENTO DA INFLAÇÃO

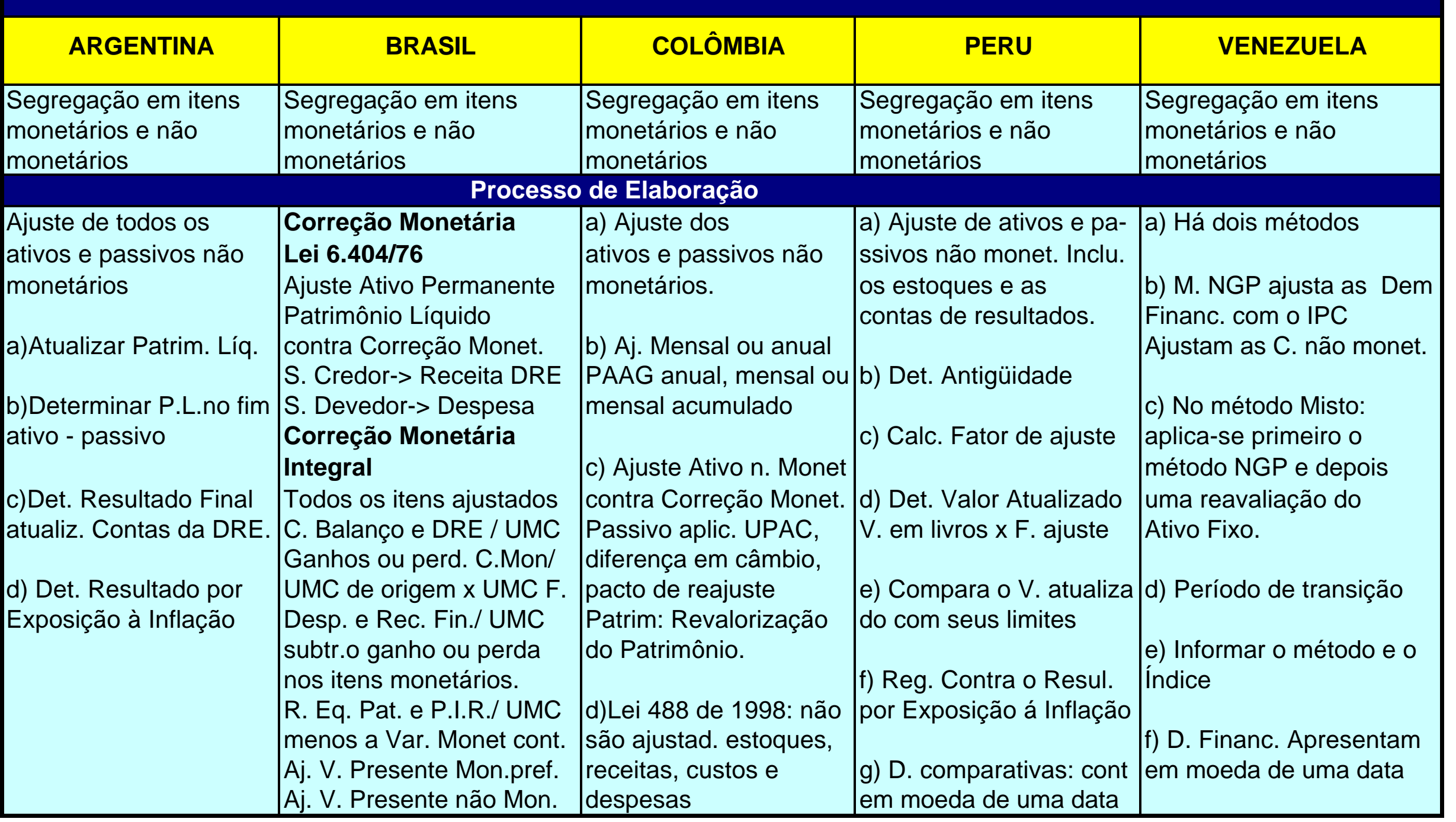


5.- CONSI DERAÇÕES FI NAIS 
1. Depois de estudar as normas contábeis dos cinco países, se observa que não há harmonização entre eles.

A harmonização contábil, necessária para a obtenção da integração e o desenvolvimento econômico e social desta região, poderia conseguir-se com a criação de um Marco conceitual contábil amplo que respeite as características específicas, regionalidades, modalidades operacionais, normas jurídicas nacionais.

Este marco deve idealmente utilizar o método dedutivo partindo do cenário dos países, analisando os objetivos, os tipos de usuários, os requisitos da informação contábil, as demonstrações contábeis, os modelos contábeis, e os aspectos econômicos.

2. A aplicação das Normas Internacionais de Contabilidade na preparação das demonstrações financeiras pode conduzir à harmonização das normas contábeis e deve ser considerada na emissão das normas pelos Países.

3. No Brasil deveriam ser reconhecidos os efeitos inflacionários nas demonstrações contábeis quando a inflação atinja níveis de $8 \%$ anuais, como a Argentina faz, devido a que é bem mais adequado do que a alternativa de reconhecê-los a partir de $100 \%$ de inflação acumulada a cada três anos, como prefere o CFC. 
4. Outro item importante é a eliminação do Ativo Diferido, o que não está sendo considerado na revisão das práticas contábeis no Brasil (anteprojeto de lei transitando pelo Congresso Nacional). Neste caso tanto o Brasil, a Colômbia e a Venezuela estão em divergência com o IAS 9.

5. Não existe harmonia dentro dos cinco países pesquisados sobre a natureza do índice de inflação para reconhecê-la nas demonstrações contábeis: há países que usam índices de varejo ou consumidor, e outros países usam índices de atacado.

6. Na aplicação do Método da Equivalência Patrimonial, se observa que não há harmonia nos cinco países, mas que o Brasil estabelece porcentagens nos investimentos relevantes e normas que são mais complexas que nos outros países. Não há harmonia com as normas do IASC.

7. No Leasing não há harmonia entres os cinco países e tampouco se respeita o princípio da essência econômica sobre a forma no Brasil, na Colômbia e no Peru, devido a que o Leasing Financeiro é tratado como Leasing Operacional, quando deveria ser considerado como uma compra/venda financiada como é realmente sua essência. Não estão de acordo com as normas do IASC. 


\section{REFERÊNCI AS BI BLI OGRÁFI CAS}

ANEFAC. Comissão de Economia, Finanças e Banking. Sub-Comissão de 
Mercosul. Pesquisa - Mercosul. São Paulo.

BLATT, Adriano. Leasing uma abordagem prática. 1. ed. Rio de Janeiro: Qualitymark. Ed., 1998.

BLAKE, John, AMAT Oriol. European Accounting. 1.ed. London: Pitman Publishing, 1983.

BRANDÃO, Antonio Salazar, PEREIRA, Lia Valls. Mercosul perspectivas de

Integração. 1 ed. São Paulo: Fundação Getúlio Vargas, 1993.

BRANDT, Valnir Alberto. A estrutura tributária do Brasil e da Argentina - Um estudo comparativo. São Paulo, 2000. 131 p. Tese (Mestrado). Faculdade de Economia, Administração e Contabilidade.

CARPIO, Fernando Catacora. PCGA en Venezuela, Comentarios y Analisis de

todas las Declaraciones e Principios de Contabilidad vigentes en Venezuela.

Caracas, 1999.

C.C.P.L. Colegio de Contadores Públicos de Lima. Normas Internacionales de

Contabilidad. 2.ed. Lima: Asociación Internacional de Editores, 1997.

C.C.P.A. Colegio de Contadores Públicos de Arequipa. Legislación del Contador Público. 1. ed. Arequipa, Perú: C.C.P.A., 1998 - 1999.

C.F.C. Conselho Federal de Contabilidade. Princípios Fundamentais de 
Contabilidade e normas brasileiras de contabilidade. São Paulo: Atlas, 1995.

C.F.C. Conselho Federal de Contabilidade. Resolução CFC $n^{0}$ 803.

http://www.brnet.com.br/pages/crcdf/res803.htm

C.F.C. Conselho Federal de Contabilidade. Resolução CFC no $825 / 98$

http://www.brnet.com.br/pages/crcdf/estat.htm.

C.R.C. Conselho Regional de Contabilidade do Estado de São Paulo.

Contabilidade no Contexto International. 1.ed. Vol 9. São Paulo: Editora Atlas

S.A., 1997. 159 p.

CHOI, Frederick D. S. e MUELLER, Gerhard D. International Accounting. $2^{\mathrm{a}}$.ed. New. Jersey. Prentice Hall, 1992.

CONASEV. Reglamento para la preparación de información financeira e información auditada. 1.ed. Lima: Conasev, 1998.

CONSELHO FEDERAL DE EDUCAÇÃO. Resolução №03 de 05 de Outubro de 1992. Brasil, 1992.

DA ROSA, Paulo Moreira. A Contabilidade no Mercosul. 1.ed. São Paulo: Editora Atlas S.A., 1999, 152p.

DOMINGOS, Antônio Padula. Diversificação estratégica das atividades dos 
profissionais contábeis. Revista de Administração; São Paulo v.31, n.2, abril/

junho 1996. p. 29-39;

FAIRLIE, Alan Reinoso. Las Relaciones Grupo Andino - Mercosur, Opciones de

integración para el Perú en un contexto de apertura. 1.ed. Lima: Fondo Editorial de La Pontificia Universidad Católica del Perú, 1997. 166 p.

F.C.C.P.V. Federación de Colegios de Contadores Públicos de Venezuela. Los

Principios de Contabilidad y las Normas y Procedimientos de Auditoría de

Aceptación General en Venezuela y Otras Publicaciones Técnicas de la

Federación de Colegios de Contadores Públicos de Venezuela. 1.ed. Caracas:

Fondo Editorial del Contador Público Venezolano, 1996. 177p.

FINANCIAL ACCOUNTING STANDARDS BOARD - FASB. Current text Accounting standards. V.I e II. John Wiley \& Sons, New York, Edição 1997/98. FIPECAFI, IUDÍCIBUS, Sérgio de, MARTINS, Eliseu, GELBCKE, Ernesto Rubens. Manual de contabilidade das sociedades por ações. 5ed. São Paulo: Ed. 
Atlas, 2000, 508p.

FORTUNA, Eduardo. Mercado Financeiro: Produtos e Serviços. 12.ed. Rio de Janeiro: Editora Qualitymark ED., 1999.

FRANCO, Hilário. A Contabilidade na Era da Globalização. 1.ed. São Paulo: Atlas S.A., 1999, 400p.

GIRALDO, Demetrio Jara. Estados Financieros. Teoría y Práctica. 3.ed. Lima:

Ed. San Marcos, 1996.

GONZÁLEZ, Patrícia González. Revisão crítica do Sistema de correção monetária Vigente na Colômbia, sob uma perspectiva de técnica desenvolvida no Brasil.

São Paulo, 1999. Tese (Mestrado) - Faculdade de Economia, Administração e Contabilidade da Universidade de São Paulo.

GRADOS, Alfonso. El Grupo Andino y su Plan de Acción ante recientes Iniciativas integracionistas. Integración Americana, Revista Mensual del Intal, Buenos Aires, Argentina. n. 176, p. 38 -49. marzo, 1992.

GRIEN, Raúl. La Integración económica como alternativa inédita para América Latina. 1 ed. México: México,1994.

HIRST, Mónica. Condicionantes y motivaciones del proceso de integración $y$

fragmentación en América Latina. Integración Americana; Revista Mensual del Intal; Buenos Aires; Argentina. n.175, p. 19 - 31. enero - febrero, 1992.

IASC. International Accounting Standards Committee. International Accounting Standards - IAS. London, 2000. 
IBRACON. Princípios contábeis. 2 ed. São Paulo: Ed. Atlas, 1994.

IBRACON. NPC 7 Ativo Imobilizado. São Paulo, 2001. 18p.

IFAC e IBRACON. Normas Internacionais de Auditoria. Brasil, 1998. p. 372-417. INFORMATIVO CABALLERO BUSTAMANTE. Lima, Perú. N. 421, abril 1999. 10p. Manual de Consultoría Contable. 1 ed. Lima, Perú. 1999, 98p. Informes Contables. 1.ed. Lima, Perú. 1999, 98p.

INSTITUTO PARA LA INTEGRACION DE AMERICA LATINA - BANCO INTERAMERICANO DE DESARROLLO. Derecho de la Integración Económica Regional. Tomo I e II. 1.ed. Buenos Aires: Depalma, 1985. IOB, Temática Contábil e Balanços. Arrendamento mercantil (leasing). (1 parte) São Paulo, outubro 1998, 8p.

Arrendamento mercantil (leasing). (2 parte). São Paulo, outubro 1998, 7p.

Arrendamento mercantil (leasing ) (3 parte). São Paulo, outubro 1998, 5p.

Arrendamento mercantil (leasing ) (1 e 2 parte). São Paulo. N. 46 e 47, novembro 2000, $15 p$.

Aspectos Financeiros do Arrendamento Mercantil. São Paulo.

n. 23, Junho 1999. 5p.

Quais Investimentos devem ser avaliados pela Equivalência 
Patrimonial? (1 e 2 parte). São Paulo. n. 40 e 41, outubro 1999, 16p.

Quais Investimentos devem ser avaliados pela

Equivalência

Patrimonial? (1 parte). São Paulo. n. 45, novembro 2001, 7p.

Normas e Procedimentos de Contabilidade do IBRACON - NPC

02-

Estoques - Texto Revisado e Atualizado em 1999. São Paulo, n. 1, janeiro de

$2000,5 p$.

Imposto de Renda e Legislação Societária. Investimentos

avaliados

pela Equivalência Patrimonial - Resultado de Avaliação - Lucros e Dividendos

recebidos. São Paulo. N. 23, junho 1999, 6p.

IUDíCIBUS, Sérgio de. Teoria da Contabilidade. 5.ed. São Paulo: Editora Atlas

S.A., 1997. 330p.

IUDÍCIBUS, Sérgio de, e MARION, José Carlos. As Faculdades de Ciências

Contábeis e a formação do Contador. Revista Brasileira de Contabilidade, Brasília, 1986, N. 56, p. $50-56$.

IVERA ASOCIADOS, C.P.C. ATAUPILLCO, Dante Vera. Impuesto a la Renta, 
Ajustes por Inflación, Flujos de Efectivo. 1.ed. Lima: Editorial Ivera, 1997.

JUNTA DEL ACUERDO DE CARTAGENA - INSTITUTO PARA LA INTEGRACION DE AMERICA LATINA. Estratégias de Desarrollo e integración en el Grupo Andino. 1.ed. Lima: Lima,1985.

KISIC, Drago. El proceso de armonización de políticas nacionales en el Grupo

Andino. Integración Americana, Revista Mensual del Intal, Buenos Aires,

Argentina. n. 176, p. 13 - 25. marzo, 1992.

LEI № 6.404 de 15 de dezembro de 1976 alterada pela Lei ํํ 9.457 de 5 de maio de 1997.

LISBOA, Lázaro. FIPECAFI, FEA, USP. Apostila: Contabilidade Internacional. Por que Contabilidade Internacional. São Paulo, 1998.

LISBOA, Nahor Plácido. Uma contribuição ao estudo da harmonização de normas

contábeis. São Paulo, 1995. 152p. Tese (Mestrado) - Faculdade de Economia,

Administração e Contabilidade da Universidade de São Paulo. Harmonização de Normas e Práticas Contábeis no Mercosul. São 
Paulo, 2000. 122p. Tese (Doutorado) - Faculdade de Economia, Administração

e Contabilidade da Universidade de São Paulo.

MATARAZZO, Dante C. Análise Financeira de Balanços. 4.ed. São Paulo: Atlas

S.A., 1997, 463p.

MANCERA, Jorge Rodriguez. Reflexiones sobre la integración andina en un

contexto de apertura económica. Integración Americana, Revista Mensual

del Intal, Buenos Aires, Argentina. n. 176, p. 3 - 12. marzo, 1992.

MARION, José Carlos. Efeitos do ensino da contabilidade na qualidade do

profissional. Revista Brasileira de Contabilidade, Brasília, 1985, N. 52, p. 3031.

MARTINS, Eliseu. Análise da Correção Monetária das Demonstrações Financeiras

1.ed. São Paulo: Atlas S.A., 1993, 157p.

MARTINS, Gilberto de Andrade. Manual para Elaboração de Monografias e

Dissertações. 2.ed. São Paulo: Atlas., 2000, 116p.

MIGUEL, Fábio Luiz Peres. As faces do Mercosul: a explosão do comércio no 
bloco. Revista Trevisan. São Paulo. n. 117. nov/97.

MINISTERIO DE EDUCAÇÃO NACIONAL. Resolução 045 de 13 de abril de 1998. Colômbia. http://www.jccconta.gov.co/Instructivo.htm

MINISTERIO DE EDUCAÇÃO NACIONAL. Resolução 116 de 14 de outubro de 1999. Colômbia. http://www.jccconta.gov.co

MOURA DA SILVA, Tânia. A Profissão Contábil no Mercosul. Revista Brasileira de Contabilidade, Brasília, 1998. p. 32-46.

MOST, Kenneth S. Advances in International Accounting. 1.ed. London: Jai Press

INC, 1987.

NETO, Alexandre Assaf. Estrutura e Análise de Balanços. 4.ed. São Paulo: Atlas S.A., 1998, 292p.

PACCEZ, João Domiraci. A Operação de Leasing no Brasil. Aspectos Contábeis, Tributários e Financeiros. 1.ed. São Paulo, Feb. 1999 153p.

PARDO, Gabriel Ibarra. El derecho del tráfico económico en el Grupo Andino.

Integración Americana, Revista Mensual del Intal, Buenos Aires, Argentina. n.

176, p. 26 - 37. marzo, 1992.

PEREDA, Jorge Tua. La armonización contable internacional. InterAmérica, 
Asociación Interamericana de Contabilidad, Miami, U.S.A. año III, n. 8 ,

p. 62 - 79. enero - junio, 2000.

POHLMANN, Marcel Coletto. Harmonização contábil no Mercosul: a profissão e o processo de emissão de normas - uma contribuição. São Paulo, 1994. $181 \mathrm{p}$.

Tese (Mestrado) - Faculdade de Economia, Administração e Contabilidade da

Universidade São Paulo.

RADEBAUGH, Lee H. e GRAY, Sidney J. International Accounting and Multinational Enterprises. $4^{\text {a }}$.ed. New York: J. Wiley \& Sons, Inc., 1997.

RBC. O interesse público, as normas de referência (benchmark) e o atendimento das expectativas. Revista Brasileira de Contabilidade; Ano XXVII-n. 112, Brasil, Julho/Agosto, 1998. p. 46-59.

Régimen Contable Colombiano, Santa Fé de Bogotá: Legis Editores S.A., 1996. RÉGO, Elba Cristina Lima. O processo de integração. Revista do BNDES. São

Paulo . vol2, n.3., jun/95.

ROMERO, Alejandro Caballero. Los Princípios y sus relaciones con las Leyes,

Axiomas, Teorías, Doctrinas y Normas. El Contador Público. Lima, abril, 2000. RUEDA, Gregorio Reyes. Plan Contable General Revisado. Estructurado $y$ 
Comentado. 1.ed. Lima: Edigraber, 1999.

SCHMIDT, Paulo. A realidade do Pós - Graduação "Strito sensu" no Brasil.

Contab. Vista \& Rev. Belo Horizonte, v.8, n.2, p. 40-48, out. 1997.

Students for ACC 584. International Accounting Pages. Internet: http://www.msm.byu.edu/c\&i/cim/account/

U.B.A. Universidad de Buenos Aires, Facultad de Ciencias Económicas, Instituto de Investigaciones Contables "Profesor Juan Alberto Arévalo" Programación

Científica 1998/2000 UBAC y T TRIENAL. Proyecto TE23 Determinación de las

“bases teóricas” para la armonización de normas contables en el MERCOSUR.

Sexto borrador de las Conclusiones. Buenos Aires, 2000. 59p.

VEIGA, Pedro da Motta. Siete hipótesis sobre los procesos de regionalización y la integración del Cono Sur. Integración Americana, Revista Mensual del Intal, Buenos Aires, Argentina. n. 175, p. 13 - 18. enero - febrero, 1992.

YAMAMOTO, Marina Mitiyo. A contabilidade e o Mercosul. São Paulo, 1996. $219 p$

Tese (Doutorado) - $\quad$ Faculdade de Economia, Administração e Contabilidade

da Universidade de São Paulo.

YCHOCAN, Segundo Arma. ABC sobre Ajuste de los Estados Financieros por 
Efectos de la Inflación. 1.ed. Arequipa, Peru, 2000. 313p.

Páginas da Internet:

http://www.ccpl.org.pe/

http://www.cfc.org.br/

http://www.cienciaseconomicas.com/fagce.htm/

http://www.comunidadeandina.org

http://www.facpce.com.ar/

http://www.fccpv.org/

http://www.financewise.com

http://www.foro-euroandino98.org/espanol/lanuevarealidadandina/

http://www.ibracon.com.br

http://www.incp.org.co

http://www.jccconta.gov.co/

http://www.mercosul.org

http://www.mercosur.com

http://www.sice.oas.org/trade

http://www.vitrine.com.br/dinheiro/ 


\section{ANEXOS}

\section{1.- PRI NCÍ PIOS CONTÁBEIS NA AMÉRI CA DO SUL}

\section{1.- ARGENTINA}

FACPCE - RT $n^{0} 16^{1}$

\section{"Requisitos da Informação nas Demonstrações Contábeis}

No cumprimento de sua finalidade, a informação das demonstrações contábeis deve reunir os requisitos enunciados no presente capítulo, devem ser considerados no seu conjunto e procurando um equilíbrio entre eles, mediante a aplicação do critério profissional.

Este capítulo apresenta:

a) uma descrição sintética dos seguintes atributos, que a informação contida nas demonstrações contábeis deveria reunir para ser útil a seus usuários;

b) considerações sobre as restrições que condicionam o sucesso das qualidades indicadas.

\footnotetext{
${ }^{1} \mathrm{http}: / / \mathrm{www}$. facpce.com.ar
} 


\section{Atributos:}

\section{1) Pertinência}

A informação deve ser capaz de satisfazer as necessidades dos usuários Geralmente isto ocorre com a informação que:

a) permite aos usuários confirmar ou corrigir avaliações realizadas anteriormente (tem um valor confirmatório), ou também;

b) ajuda aos usuários a aumentar a probabilidade de predizer corretamente as conseqüências futuras dos fatos passados e presentes.

São exemplos de informações pertinentes as enunciadas nos objetivos das demonstrações contábeis.

\section{2) Confiabilidade (Credibilidade)}

A informação deve ser acreditável para seus usuários, de maneira que estes a aceitem para a tomada de suas decisões.

Para que a informação seja confiável, deve reunir os requisitos de aproximação à realidade e verificável.

\section{1) Aproximação à realidade}

As demonstrações contábeis para ser acreditáveis, devem apresentar descrições e mensurações que tenham correspondência razoável com os fatos que pretendem descrever, pelo qual não devem estar afetadas por erros ou 
omissões importantes, nem por deformações dirigidas a beneficiar os interesses particulares do emissor ou de outras pessoas.

Não obstante que a procura de aproximação à realidade é imperativa, é normal que a informação contábil seja inexata. Isto se deve a que:

- a identificação das operações e outros fatos que os sistemas contábeis devem mensurar não está isenta de dificuldades.

- um número importante de acontecimentos e circunstâncias (como a cobrança dos créditos, a vida útil provável dos bens imóveis ou o custo de satisfazer reclamos por garantias pós-venda), envolve incertezas sobre fatos futuros, os quais obrigam a efetuar estimações, que em alguns casos se referem a:

a) o grau de probabilidade, que como conseqüência de um fato determinado, a entidade vai receber ou esteja obrigado a entregar bens ou serviços.

b) As mensurações contábeis a atingir a esses bens ou serviços a receber ou entregar

- No cumprimento de que a informação se aproxime à realidade, deve cumprir com os requisitos de essencialidade, neutralidade e integridade. 


\subsection{1) Essencialidade (substância sobre a forma)}

A informação contábil para que se aproxime à realidade, as operações e fatos devem contabilizar-se e expor-se se baseando em sua substancia ou realidade econômica.

\subsection{2) Neutralidade (Objetividade)}

A informação contábil para que se aproxime à realidade, não deve estar cortada, deformada para favorecer à entidade emissora ou para influenciar a conduta dos usuários numa direção. As demonstrações contábeis não são neutrais se, através da seleção ou apresentação de informação, influem na tomada de uma decisão ou na formação de um juízo com o propósito de obter um resultado predeterminado.

As demonstrações contábeis para que sejam neutrais, seus preparadores devem atuar com objetividade.

\subsection{3) Integridade}

A informação contida nas demonstrações contábeis deve ser completa.

A omissão de informação pertinente e significativa pode converter à informação apresentada em falsa ou conduzir a erro e, portanto, não confiável.

\section{2) Verificável}

A informação contábil, para que seja confiável, deve ser susceptível de comprovação por qualquer pessoa com perícia suficiente. 


\section{3) Sistematicidade}

A informação contábil proporcionada deve estar organicamente ordenada, com base nas regras contidas nas normas contábeis profissionais.

\section{4) Comparabilidade}

A informação contida nas demonstrações contábeis de uma entidade deve ser suscetível de comparação com outras informações.

a) da mesma entidade na mesma data ou período;

b) da mesma entidade em outras datas ou períodos;

c) de outras entidades.

Os dados informados por uma entidade em um conjunto de demonstrações contábeis para que sejam comparáveis entre si requere-se:

a) que estejam expressos na mesma unidade de medida;

b) que os critérios usados para quantificar dados sejam coerentes;

c) que, quando as demonstrações contábeis incluam informação em várias datas ou períodos, todos seus dados estejam preparados sobre as mesmas bases.

A maior comparabilidade entre os dados contidos em sucessivos conjuntos de demonstrações contábeis do mesmo emissor se poderia conseguir se: 
a) se usa-se as mesmas regras (uniformidade ou conseqüência);

b) os períodos comparados fossem de igual duração;

c) esses períodos não estivessem afetados pelas conseqüências de operações de temporada; e

d) não existissem outras circunstâncias que afetem as comparações, como a incorporação de novos negócios, a descontinuidade de uma atividade ou uma linha de produção ou a ocorrência de um sinistro que houvesse afetado as operações.

Na comparação de demonstrações contábeis de entidades diferentes devese dar atenção às normas aplicadas por cada um deles, já que a comparabilidade pode ser dificultada se elas não concordassem.

\section{5) Clareza (compreensibilidade)}

A informação deve preparar-se utilizando uma linguagem precisa, que evite as ambigüidades, e que seja inteligível e fácil de compreender pelos usuários que estão dispostos a estudá-la diligentemente e que tenham um conhecimento razoável das atividades econômicas, do mundo dos negócios e da terminologia própria das demonstrações contábeis. 


\section{Restrições que condicionam o sucesso dos requisitos:}

\section{1) Oportunidade}

A informação deve proporcionar-se em tempo conveniente para os usuários, de modo tal que tenha a possibilidade de influir na tomada de decisões. Um atraso indevido na apresentação da informação pode fazer perder sua pertinência.

É necessário balançar os benefícios relativos da apresentação oportuna e da confiabilidade da informação contábil.

$\mathrm{Na}$ procura do equilíbrio entre relevância e confiabilidade, deveria considerar-se a melhor forma de satisfazer as necessidades da tomada de decisões econômicas por parte dos usuários tipo.

\section{2) Equilíbrio entre custos e benefícios}

No aspecto social, os benefícios derivados da disponibilidade de informação deveriam exceder às despesas de proporcioná-la.

A aplicação concreta de uma prova de custo-benefício a cada caso individual não é simples, porque as despesas de preparar demonstrações contábeis não recaem sobre os usuários tipo definidos neste marco (exceto os proprietários da entidade).

As normas contábeis profissionais não poderão deixar de aplicar-se por razões de custo, mas estas poderão ser consideradas quando ditas normas 
aceitem que, por essa razão se apliquem determinados procedimentos alternativos. Nesses casos, os emissores das demonstrações contábeis devem demonstrar que essas razões de custo realmente existem".

\section{2.- BRASIL}

Resolução CFC № 750 de 29/12/93²

\section{"1) O Princípio da Entidade}

Art. 4ํำ Princípio da ENTIDADE reconhece o Patrimônio como objeto da Contabilidade e afirma a autonomia patrimonial, a necessidade da diferenciação de um Patrimônio particular no universo dos patrimônios existentes, independentemente de pertencer a uma pessoa, um conjunto de pessoas, uma sociedade ou instituição de qualquer natureza ou finalidade, com ou sem fins lucrativos. Por conseqüência, nesta acepção, o patrimônio não se confunde com aqueles dos seus sócios ou proprietários, no caso de sociedade ou instituição.

Parágrafo único. O PATRIMÔNIO pertence à ENTIDADE, mas a recíproca não é verdadeira. A soma ou agregação contábil de patrimônios autônomos não resulta em nova ENTIDADE, mas numa unidade de natureza econômico-contábil.

\footnotetext{
${ }^{2}$ Resolução CFC № 750 de 29/12/93 citado por Sérgio de Iudícibus. Teoria da Contabilidade. 1997. P. 8487.
} 


\section{2) O Princípio da continuidade}

Art. $5^{0}$ A CONTINUIDADE ou não da ENTIDADE, bem como sua vida definida ou provável, deve ser considerada quando da classificação e avaliação das mutações patrimoniais, quantitativas e qualitativas.

$\S 1^{\underline{0}}$ A CONTINUIDADE influencia o valor econômico dos ativos e, em muitos casos, o valor ou o vencimento dos passivos, especialmente quando a extinção da ENTIDADE tem prazo determinado, previsto ou previsível.

$\S 2^{0}$ A Observância do Princípio da CONTINUIDADE é indispensável à correta aplicação do Princípio da COMPETÊNCIA, por efeito de se relacionar diretamente à quantificação dos componentes patrimoniais e à formação do resultado, e de constituir dado importante para auferir a capacidade futura de geração de resultado.

\section{3) O Princípio da Oportunidade}

Art. $6^{0}$ O Princípio da OPORTUNIDADE, refere-se, simultaneamente, à tempestividade e à integridade do registro do patrimônio e das suas mutações, determinando que este seja feito de imediato e com a extensão correta, independentemente das causas que as originaram.

Parágrafo único. Como resultado da observância do Princípio da OPORTUNIDADE: 
I - desde que tecnicamente estimável, o registro das variações patrimoniais deve ser feito mesmo na hipótese de somente existir razoável certeza de sua ocorrência;

II - o registro compreende os elementos quantitativos e qualitativos, contemplando os aspectos físicos e monetários;

III - o registro deve ensejar o reconhecimento universal das variações ocorridas no patrimônio da ENTIDADE, em um período de tempo determinado, base necessária para gerar informações úteis ao processo decisório da gestão.

\section{4) O Princípio do registro pelo valor original}

Art. $7^{0}$ Os componentes do patrimônio devem ser registrados pelos valores originais das transações com o mundo exterior, expressos a valor presente na moeda do País, que serão mantidos na avaliação das variações patrimoniais posteriores, inclusive quando configurarem agregações ou decomposições no interior da ENTIDADE.

Parágrafo único. Do Princípio do REGISTRO PELO VALOR ORIGINAL resulta:

I - a avaliação dos componentes patrimoniais deve ser feita com base nos valores de entrada, considerando-se como tais os resultantes do consenso com os agentes externos ou da imposição destes;

II - uma vez integrado no patrimônio, o bem, direito ou obrigação não poderão ter alterado seus valores intrínsecos, admitindo-se, tão somente, sua 
decomposição em elementos e/ou sua agregação, parcial ou integral, a outros elementos patrimoniais;

III - o valor original será mantido enquanto o componente permanecer como parte do patrimônio, inclusive quando da saída deste;

IV - os Princípios da ATUALIZAÇÃO MONETÁRIA e do REGISTRO PELO VALOR ORIGINAL são compatíveis entre si e complementares, dado que o primeiro apenas atualiza e mantém atualizado o valor de entrada;

V - o uso da moeda do País na tradução do valor dos componentes patrimoniais constitui imperativo de homogeneização quantitativa dos mesmos.

\section{5) O Princípio da Atualização Monetária}

Art. $8^{0}$ Os efeitos da alteração do poder aquisitivo da moeda nacional devem ser reconhecidos nos registros contábeis através do ajustamento da expressão formal dos valores dos componentes patrimoniais.

Parágrafo único. São resultantes da adoção do Princípio da ATUALIZAÇÃO MONETÁRIA:

I - a moeda, embora aceita universalmente como medida de valor, não representa unidade constante em termos do poder aquisitivo;

II - para que a avaliação do patrimônio possa manter os valores das transações originais (art. $7^{0}$ ), é necessário atualizar sua expressão formal em 
moeda nacional, a fim de que permaneçam substantivamente corretos os valores dos componentes patrimoniais e, por conseqüência, o do patrimônio líquido;

III - a atualização monetária não representa nova avaliação, mas, tãosomente, o ajustamento dos valores originais para determinada data, mediante a aplicação de indexadores, ou outros elementos aptos a traduzir a variação do poder aquisitivo da moeda nacional em um dado período.

\section{6) O Princípio da Competência}

Art. 9ํㅡ As receitas e as despesas devem ser incluídas na apuração do resultado do período em que ocorrerem, sempre simultaneamente quando se correlacionarem, independentemente do recebimento ou pagamento.

$\S 1^{\underline{0}} \mathrm{O}$ Princípio da COMPETÊNCIA determina quando as alterações no ativo ou no passivo resultam em aumento ou diminuição no patrimônio líquido, estabelecendo diretrizes para classificação das mutações patrimoniais, resultantes da observância do Princípio da OPORTUNIDADE.

$\S 2^{0}$ O reconhecimento simultâneo das receitas e despesas, quando correlatas, e conseqüência natural do respeito ao período em que ocorrer sua geração.

$\S 3^{0}$ As receitas consideram-se realizadas:

I - nas transações com terceiros, quando estes efetuarem o pagamento ou assumirem compromisso firme de efetivá-lo, quer pela investidura na propriedade 
de bens anteriormente pertencentes à ENTIDADE, quer pela fruição de serviços por esta prestados;

II - quando da extinção, parcial ou total, de um passivo, qualquer que seja o motivo, sem o desaparecimento concomitante de um ativo de valor igual ou maior;

III - pela geração natural de novos ativos independentemente da intervenção de terceiros;

IV - no recebimento efetivo de doações e subvenções.

$\S 4^{0}$ Consideram-se incorridas as despesas:

I - quando deixar de existir o correspondente valor ativo, por transferência de sua propriedade para terceiro;

II - pela diminuição ou extinção do valor econômico de um ativo;

III - pelo surgimento de um passivo, sem o correspondente ativo.

\section{7) O Princípio da Prudência}

Art. $10^{0}$ O Princípio da PRUDÊNCIA determina a adoção do menor valor para os componentes do ATIVO e do maior para os do PASSIVO, sempre que se apresentem alternativas igualmente válidas para a quantificação das mutações patrimoniais que alterem o patrimônio líquido. 
$\S 1^{10}$ O Princípio da PRUDÊNCIA impõe a escolha da hipótese de que resulte menor patrimônio líquido, quando se apresentarem opções igualmente aceitáveis diante dos demais Princípios Fundamentais de Contabilidade.

$\S 2^{20}$ Observado o disposto no art. $7^{0}$, o Princípio da PRUDÊNCIA somente se aplica às mutações posteriores, constituindo-se ordenamento indispensável à correta aplicação do Princípio da COMPETÊNCIA.

$\S 3^{0}$ A aplicação do Princípio da PRUDÊNCIA ganha ênfase quando, para definição dos valores relativos às variações patrimoniais, devem ser feitas estimativas que envolvem incertezas de grau variável."

\section{Os Princípios fundamentais segundo a CVM e o IBRACON:} Deliberação nํㅜ 29/86 da CVM que aprovou o pronunciamento do lbracon. ${ }^{3}$

"São divididos em três subcategorias (hierárquicas):

\section{A. Os Postulados}

A1. Da Entidade: A Contabilidade é mantida para as entidades: os sócios ou quotistas desta e não se confunde, para efeito contábil, com aquelas.

A2. Da Continuidade: Para a Contabilidade, a entidade é um organismo vivo que irá viver (operar) por um longo período de tempo (indeterminado) até que surjam fortes evidências em contrário.

\footnotetext{
${ }^{3}$ Resolução CFC № 750 de 29/12/93 citado por Sérgio de Iudícibus. Teoria da Contabilidade. 1997. P. 8487.
} 


\section{B. Os Princípios Propriamente Ditos}

B1. Do Custo como Base de Valor: O custo de aquisição de um ativo ou dos insumos necessários para fabricá-lo e colocá-lo em condições de gerar benefícios para a entidade representa a base de valor para Contabilidade, expresso em termos de moeda de poder aquisitivo constante.

B2. Do Denominador Comum Monetário: As demonstrações contábeis, sem prejuízo dos registros detalhados de natureza qualitativa e física, serão expressas em termos de moeda nacional de poder aquisitivo da data do último Balanço Patrimonial.

B3. Da Realização da Receita: A receita é considerada realizada e, portanto, passível de registro pela Contabilidade, quando produtos ou serviços produzidos ou prestados pela entidade são transferidos para outra entidade ou pessoa física com a anuência destas e mediante pagamento ou compromisso de pagamento especificado perante a entidade produtora.

\section{B4. Do Confronto das Despesas com as Receitas e com os Períodos}

Contábeis: Toda despesa diretamente delineável com as receitas reconhecidas em determinado período com as mesmas deverá ser confrontada; os consumos ou sacrifícios de ativos (atuais ou futuros), realizados em determinado período e que não puderem ser associados à receita do período nem às dos períodos futuros, deverão ser descarregados como despesa do período em que ocorrerem. 


\section{As Convenções (Restrições)}

C1. Da Objetividade: Para procedimentos igualmente relevantes, resultantes da aplicação dos princípios, preferir-se-ão, em ordem decrescente: A) Os que puderem ser comprovados por documentos e critérios objetivos; B) Os que puderem ser corroborados por consenso de pessoas qualificadas da profissão, reunidas em comitês de pesquisa, ou em entidades que têm autoridade sobre princípios contábeis.

C2. Da Materialidade (Relevância): O contador deverá, sempre, avaliar a influência e materialidade da informação evidenciada ou negada para o usuário à luz da relação custo-benefício, levando em conta aspectos internos do sistema contábil.

C3. Do Conservadorismo (Prudência): Entre conjuntos alternativos de avaliação para o patrimônio, igualmente válidos, segundo os princípios fundamentais, a Contabilidade escolherá o que apresentar o menor valor para o ativo e o maior para as obrigações.

C4. Da Consistência (Uniformidade): A Contabilidade de uma entidade deverá ser mantida de forma tal que os usuários das demonstrações contábeis tenham a possibilidade de delinear a tendência da mesma com o menor grau de dificuldade possível." 


\section{3.- COLÔMBIA}

Decreto 2649 de 1993 em concordância com a Lei 43 de $1990 .^{4}$

"Art. 5․- As normas básicas são o conjunto de postulados, conceitos e limitações, que fundamentam a informação contábil, com o objetivo de que ela goze dos atributos anteriores. As normas básicas são:

\section{1) O Ente Econômico:}

Art. 6으 Onte Econômico é a empresa, a atividade econômica organizada como uma unidade, onde se realiza o controle dos recursos. $O$ ente deve ser definido e identificado, para ser distinto dos outros entes. O Ente Econômico pode ser:

a) Comercial:

- Individual

- Social: Compreende: Sociedades de comércio, Instituições do setor financeiro e de seguros, Instituições do mercado de valores.

- Empresa Unipessoal

b) No Comercial: compreende: Setor cooperativo, Caixas de compensação familiar, Fundos mútuos de investimentos, Fundos de empregados, Associações, Sindicatos, Corporações, Fundações de beneficência, Sociedades e outros.

\footnotetext{
${ }^{4}$ Régimen Contable Colombiano. 1996.
} 
c) Sem natureza jurídica: compreende: Sociedade de fato, Contas em participação, Patrimônio autônomo, Consórcios, Uniões temporais.

\section{2) Continuidade:}

Art. $7^{0}$ Os recursos e fatos econômicos devem ser contabilizados levando em consideração se a entidade econômica continuará ou não funcionando normalmente em períodos futuros. Se a entidade econômica não for continuar, a informação contábil deverá expressar esse fato.

$\mathrm{Na}$ avaliação da continuidade de uma entidade econômica devem se considerar fatos que possam indicar que a entidade econômico não vai continuar funcionando normalmente como:

- Tendências negativas (perdas reiteradas, deficiências do capital do trabalho, fluxos de caixa negativos).

- Indícios de possíveis dificuldades financeiras (não cumprimento de obrigações, problemas de acesso ao crédito, refinanciamentos, venda de ativos importantes).

- Outras situações internas ou externas (restrições jurídicas sobre a atividade econômica, greves, catástrofes naturais).

A aplicação do valor de realização ou de mercado definido no art. 10, como critério de mensuração não constitui um indicador de perda da continuidade da entidade econômica. PAR.- Adicionado. D. 2337/95, art. 1. 


\section{3) Unidade de Mensuração:}

Art. $8^{0}$ Os diferentes recursos e fatos econômicos devem reconhecer-se em uma mesma unidade de mensuração.

Por regra geral, deve-se utilizar como unidade de mensuração a moeda funcional. A moeda funcional é o signo monetário do médio econômico no qual a entidade principalmente o consegue e usa o caixa.

O peso é a unidade monetária de mensuração para as demonstrações financeiras na Colômbia.

\section{4) Período Contábil:}

Art. 9ำ A entidade econômica deve preparar e difundir periodicamente demonstrações financeiras, durante sua existência.

Os períodos respectivos devem definir-se previamente, de acordo com normas legais e em consideração ao ciclo das operações.

Pelo menos uma vez no ano, o 31 de dezembro, a entidade econômica deve emitir demonstrações financeiras de propósito geral.

\section{5 ) Avaliação ou Mensuração:}

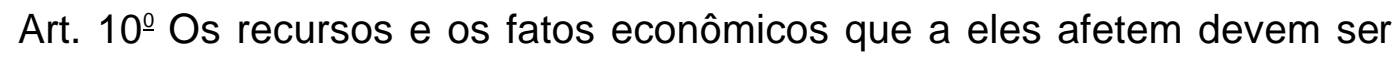
quantificados em termos da unidade de mensuração. 
São critérios de mensuração aceitos o valor histórico, o valor atual, o valor de realização e o valor presente.

Valor o custo histórico representa o montante original consumido ou obtido em caixa, ou no seu equivalente, no momento de realização de um fato econômico. Esse montante deve ser ajustado para reconhecer o efeito ocasionado pelas variações no poder aquisitivo da moeda.

Valor atual ou de reposição representa o montante em caixa, ou seu equivalente, que se consumirá para repor um ativo ou se necessitará para liquidar uma obrigação, no momento atual.

Valor de realização ou de mercado representa o montante em caixa, ou seu equivalente, em que se espera converter um ativo ou liquidar um passivo, no curso normal dos negócios. Valor líquido de realização é o resultado da subtração das despesas gastas diretamente na conversão do ativo ou na liquidação do passivo, do valor do mercado, como comissões, impostos, transporte, etc.

Valor presente ou descontado representa o montante atual das entradas ou saídas líquidas em caixa ou seu equivalente, que geraria um ativo ou um passivo, depois de fazer o desconto de seu valor futuro à taxa pactuada ou à taxa média efetiva de captação dos bancos e corporações financeiras para a expedição de certificados de depósito com um prazo de 90 dias (DTF), a qual é certificada periodicamente pelo Banco da República. 


\section{6) Essência sobre a Forma:}

Art. $11^{0}$ Os recursos e fatos econômicos devem ser reconhecidos e revelados de acordo com sua essência ou realidade econômica e não unicamente em sua forma legal.

Quando, devido a uma norma superior, os fatos econômicos não possam ser reconhecidos de acordo com a sua essência, deve-se indicar em notas às demonstrações financeiras o efeito ocasionado pelo não cumprimento daquela disposição sobre a situação financeira e os resultados do exercício.

\section{7) Realização:}

Art. $12^{0}$ Só podem reconhecer-se fatos econômicos realizados. Um fato econômico foi realizado quando pode comprovar-se que, como conseqüência de operações ou eventos passados, internos ou externos, a entidade econômica tem ou terá um benefício ou um sacrifício econômico, ou experimentou uma mudança em seus recursos, em ambos casos pode ser quantificada.

\section{8) Associação o Relação de Causalidade:}

Art. $13^{0}$ Devem-se associar junto às receitas incorridas em cada período as despesas e gastos incorridos para produzir os bens, registrando ambos simultaneamente nas contas de resultados.

Quando uma conta não possa ser associada com uma receita, despesa ou custo correlativo e conclui-se que não gerará benefícios ou sacrifícios econômicos 
em outros períodos, deve registrar-se nas contas de resultados no período corrente.

\section{9) Manutenção do Patrimônio:}

Art. 14ํㅡma entidade econômica obtém resultados, ou excedentes, em um período, unicamente depois que seu patrimônio inicial, excluídas as transferências de recursos a outras entidades realizadas de acordo com a lei, seja mantido ou recuperado. Esta avaliação compreende o patrimônio financeiro (outorgado pelos acionistas) ou o patrimônio físico (operacional).

O patrimônio financeiro deve estar devidamente corrigido para efeitos da inflação.

10) Revelação plena:

Art. $15^{\circ} \mathrm{A}$ entidade econômica deve informar completa e resumidamente tudo aquilo que seja necessário para compreender e avaliar corretamente sua situação financeira, as mudanças que experimenta, as mudanças no patrimônio, o resultado de suas operações e sua capacidade para gerar fluxos futuros de caixa.

Esta norma cumpre-se através das demonstrações financeiras de propósito geral, das notas explicativas, das demonstrações financeiras, e de outros informes. Os ditames ou informes emitidos pelos auditores, de acordo com as normas de auditoria geralmente aceitas. 


\section{1) Materialidade:}

Art. $16^{0} \mathrm{O}$ reconhecimento e apresentação dos fatos econômicos devem ser feitos de acordo com sua importância relativa.

Um fato econômico é material quando, devido a sua natureza ou quantia, seu conhecimento ou desconhecimento, levando em consideração as circunstâncias, pode modificar significativamente as decisões econômicas dos usuários da informação.

$\mathrm{Na}$ preparação das demonstrações financeiras, a materialidade deve ser determinada com relação aos seguintes itens: ativo total, ativo corrente, passivo total, passivo corrente, capital de trabalho, patrimônio, resultados do exercício.

\section{2) Conservadorismo ou Prudência:}

Art. 17ํㅡㄹ Quando existirem dificuldades para mensurar de forma que possa ser verificado um fato econômico realizado, deve-se optar pela alternativa com menos probabilidade de sobreestimar os ativos e os ingressos, ou de subestimar os passivos e as despesas.

Adicionado. D. $2337 / 95$, art. 4. Os sistemas especiais de valorização a preços de mercado com base nos quais determina-se o valor de realização ou de mercado, serão medidas confiáveis e verificáveis dos fatos econômicos realizados. 
13) Características e práticas de cada atividade:

Art. 18 $\mathrm{A}$ contabilidade deve realizar-se tomando em consideração as limitações impostas pelas características e práticas de cada atividade, a natureza de suas operações, sua localização geográfica, seu desenvolvimento social, econômico e tecnológico."

\section{4.- PERU}

Resolução Conasev №ํ0ㅇ-84-EFC/94-10, atualizado segundo R. Conasev № $252-85-E F / 94-01$ e Res. De CONT. № $005-94-E F / 93-01{ }^{5}$

"O Plano Contábil Geral Revisado reconhece que os princípios a ser expostos são fundamentais e básicos para o adequado cumprimento dos fins da contabilidade.

\section{1) Equidade}

É o princípio fundamental que deve orientar a ação do profissional contábil em todo momento e se enuncia assim:

A equidade entre interesses opostos deve ser uma preocupação constante em contabilidade, devido a que os usuários que utilizam os dados contábeis podem encontrar-se diante do fato de que os interesses individuais estejam em conflito. As Demonstrações Financeiras devem preparar-se de forma que reflitam com equidade os distintos interesses envolvidos em uma empresa. 


\section{2) Partida Dobrada}

Os fatos econômicos e jurídicos da empresa são expressos aplicando sistemas contábeis que registram os dois aspectos de cada acontecimento, mudanças no ativo e no passivo, que vão originar a equação contábil.

\section{3) Entidade}

As Demonstrações Financeiras refletem sempre o estado patrimonial de uma entidade, onde o elemento subjetivo, o proprietário, é considerado como terceiro. O conceito de entidade é distinto da pessoa, já que uma pessoa pode produzir demonstrações financeiras de várias entidades de sua propriedade.

\section{4) Bens Econômicos}

As Demonstrações Financeiras referem-se sempre a bens econômicos, ou seja, bens materiais e imateriais que possuam valor econômico e, portanto, podem ser avaliados em termos monetários.

\section{5) Denominador Comum Monetário}

As Demonstrações Financeiras refletem o patrimônio mediante um recurso que é empregado para reduzir todos seus componentes heterogêneos a uma expressão, que permita que sejam agrupados e comparados facilmente. Este recurso consiste em eleger uma moeda e valorizar os elementos patrimoniais

\footnotetext{
${ }^{5}$ Plan Contable General Revisado. Resolución Conasev № 006-84-EFC/94-10, R. Conasev № 252-85-EF/9401 y Res. De CONT. № 005-94-EF/93-01 citado por Rueda, Gregorio. PCGR. 1999. P. 27 - 30.
} 
aplicando um preço a cada unidade. No Peru a contabilidade é levada em moeda nacional: Novo Sol.

\section{6) Empresa em Movimento}

Entende-se que as Demonstrações Financeiras pertencem a uma "empresa em movimento", considerando-se que o conceito que informa esta expressão refere-se a todo organismo econômico cuja existência temporal tem vigência e projeção.

\section{7) Avaliação ao custo}

O valor de custo, aquisição ou produção, constitui o critério principal e básico da avaliação, que condiciona a formulação das demonstrações financeiras, em consonância com o conceito de "empresa em movimento".

Em caso de não existir uma circunstância especial que justifique a aplicação de outro critério, deve prevalecer o custo - aquisição ou produçãocomo conceito básico de avaliação.

As flutuações de valor da moeda comum, com os correspondentes ajustes que modificam os valores monetários dos custos de determinados bens, não constituem alterações a este princípio, mas são simples ajustes à expressão numerária dos respectivos custos. 


\section{8) Período}

Na empresa em movimento é necessário mensurar o resultado da gestão de tempo em tempo, por razões de administração, legais, fiscais ou para cumprir com compromissos financeiros.

O lapso que existe entre uma data e outra se denomina período. No Plano Contábil Geral, este período é de doze meses e recebe o nome de Exercício.

\section{9) Competência}

As variações patrimoniais que devem considerar-se para apurar o resultado econômico são as correspondentes a um período sem diferenciar as cobradas ou pagas durante esse período.

\section{0) Objetividade}

As mudanças no ativo, passivo e no patrimônio líquido devem ser reconhecidas formalmente nos registros contábeis; até onde for possível, mensurá-las objetivamente e expressar essa medida em termos monetários.

\section{1) Realização}

Os resultados econômicos devem ser computados quando sejam realizados, ou seja, quando a operação que originou esses resultados seja concluída com perfeição do ponto de vista da legislação ou práticas comerciais aplicáveis, e quando sejam considerados todo os riscos inerentes a essa operação. O conceito "realizado" participa do conceito de "competência". 


\section{2) Prudência}

Quando se deva eleger entre dois valores para um elemento do ativo, normalmente deve-se optar pelo valor mais baixo, ou contabilizando-se uma operação de forma que a participação do proprietário seja menor. Contabilizar todas as despesas quando sejam conhecidas e as receitas só quando sejam realizadas.

\section{3) Uniformidade}

Os princípios gerais, quando sejam aplicáveis e as normas particulares, princípios de avaliação, utilizados para elaborar as demonstrações financeiras de uma determinada entidade devem ser aplicáveis uniformemente de um exercício a outro. Quando existir alguma mudança, isso deve ser explicado com seu efeito nas demonstrações financeiras através de uma nota.

\section{4) Significação ou importância relativa}

$\mathrm{Na}$ aplicação dos princípios podemos ver que não existe uma divisão entre aquilo que é significativo e aquilo que não é, portanto deve-se aplicar o critério melhor de acordo com as circunstâncias, considerando fatores como o efeito relativo no ativo, passivo, patrimônio ou no resultado das operações.

\section{5) Exposição}

As demonstrações financeiras devem conter toda a informação básica e adicional que seja necessária para uma adequada interpretação da situação financeira e dos resultados econômicos da entidade." 


\section{5.- VENEZUELA ${ }^{6}$}

"Na aplicação prática dos princípios de contabilidade de aceitação geral, a profissão na Venezuela deve guiar-se primeiro pelos publicados pela Federação de Colégios de Contadores Públicos da Venezuela denominados "Declarações dos Princípios de Contabilidade-DPC" ou "Publicações Técnicas".

A DPC-0 foi emitida em abril de 1997. Representa a estrutura principal das normas contábeis na Venezuela e a base para a aplicação dos princípios contábeis geralmente aceitos PCGA".

A DPC-0 no seu parágrafo 24 estabelece o seguinte:

“24. Os princípios de contabilidade de aceitação geral são um corpo de doutrinas associadas com a contabilidade, que servem de explicação das atividades correntes ou atuais e como guia na seleção de convencionalismos ou procedimentos aplicados pelos profissionais da Contadoria Pública no exercício das atividades que lhe são próprias, em forma independente das entidades analisadas e que foram aceitas em forma geral e aprovados pela Federação de Colégios de Contadores Públicos da Venezuela analisados através de seu Comitê Permanente de Princípios de Contabilidade".

\footnotetext{
${ }^{6}$ CARPIO, Fernando Catacora. PCGA en Venezuela. Comentarios y Analisis de todas las Declaraciones y Principios de Contabilidad vigentes en Venezuela. Caracas, 1999
} 


\section{2.- ESTOQUES}

\section{1.- ARGENTINA}

\section{a) FACPCE}

$\mathrm{Na}$ Argentina a avaliação de estoques é determinada pela Resolução Técnica $n^{0} 10$ da FACPCE:

7“3.5 Estoques em geral: por seu custo de reposição, recompra ou reprodução na data a que se refere a avaliação. Em caso de impossibilidade de determinação ou estimativa desses valores, se admitirá o custo original expresso em moeda constante.

3.6 Estoques fungíveis, com mercado transparente, que possam ser comercializados sem esforço significativo de vendas: pelas respectivas cotações na data de encerramento de período nos mercados em que normalmente atua a sociedade, excluídos os custos adicionais (comissões, impostos e similares) que gerarão sua comercialização. Os valores assim determinados serão computados à medida que forem representativos dos valores estimados líquidos de realização.

3.7 Estoques em processo de produção ou construção que se prolonguem no tempo: caso sua venda não ofereça dificuldades e se possa considerar que o esforço mais significativo do processo de geração de resultados é o de produção 
ou construção, serão avaliados pelo valor líquido de realização calculado segundo o grau de avanço da produção ou construção e do correspondente processo de geração de resultados. No caso de a venda apresentar dificuldades, ou existir incerteza a respeito de concretização do lucro, a avaliação se dará pelo custo de reposição."

\section{A RT nº 16 Marco Conceitual das Normas Contábeis Profissionais (vai} entrar em vigência em 2001) ${ }^{8}$

Conceitos importantes da RT $n^{0} 16$ :

"Ativos

Uma entidade tem um ativo quando, devido a um fato já ocorrido, controla os benefícios econômicos que produzem um bem (material ou imaterial, com valor de câmbio ou de uso para a entidade).

Um bem tem um valor de câmbio quando existe a possibilidade de:

a) trocá-lo por dinheiro ou por outro ativo;

b) utilizá-lo para cancelar uma obrigação;

c) distribui-lo aos proprietários da entidade"

\footnotetext{
${ }^{7}$ http://www.facpce.com.ar/
} 
A RT n 17 Normas contábeis profissionais: desenvolvimento de aspectos de aplicação geral $^{9}$

(vai entrar em vigência em 2001).

"Em geral, a mensuração original dos bens incorporados e dos serviços adquiridos será na base de seu custo.

Determinação dos valores correntes dos ativos destinados à venda ou a ser consumidos no processo de obtenção de bens ou serviços destinados à venda. Nos casos de ativos cuja venda não requeira esforços significativos, se procederá assim:

- quando os bens estiverem em condições de ser entregues, será utilizado um valor corrente de saída;

- no caso contrário, se utilizará o valor líquido de realização proporcionado segundo o grau de avanço da produção ou construção do bem e do correspondente processo de geração de resultados.

Para os demais ativos, em geral se utilizará o valor corrente de entrada ou custo de reposição.

Nenhum ativo poderá ser apresentado nas demonstrações financeiras por um valor superior a seu valor recuperável, que é o maior valor entre:

- seu valor líquido de realização;

\footnotetext{
${ }^{8} \mathrm{http} / / / \mathrm{www}$. facpce.com.ar/
} 
- seu valor de uso, definido como o valor atual esperado dos fluxos líquidos de fundos que deveriam surgir do uso dos bens e de sua disposição ao final de sua vida útil (ou de sua venda antecipada).

Estoques: a comparação com o valor recuperável se efetuará considerando a forma de utilização ou comercialização dos bens.

\section{Mensuração dos estoques:}

Estoques fungíveis, com mercado transparente e que possam ser comercializados sem esforço significativo: Serão avaliados a valor líquido de realização.

Estoques sobre os que se tenham recebido antecipações que fixam preço, e as condições contratuais da operação que certifiquem a concretização da venda e da receita: serão avaliados a valor líquido de realização.

Estoques em produção ou construção através de um processo prolongado:

A avaliação será segundo valor líquido de realização proporcionado de acordo com o grau de avanço da produção ou construção e do correspondente processo de geração de resultados, quando:

- Foram recebidas antecipações que fixam preço;

- As condições contratuais da operação certifiquem a concretização da venda;

\footnotetext{
${ }^{9}$ http://www.facpce.com.ar/
} 
- A entidade tenha a capacidade financeira para finalizar a obra;

- Exista certeza com relação à concretização da receita.

- Nos casos que fiquem resíduos serão avaliados pelo custo de reposição dos bens com semelhante grau de avanço da produção ou construção, considerados de um mercado ativo ou, caso isto não seja possível, pelo custo de reprodução. Sendo isso impossível, será usado o custo original.

Estoques em geral: serão avaliados segundo seu custo de reposição na data das demonstrações contábeis. Se a obtenção for impossível será usado o custo original.

Se os custos estão expressos em moeda estrangeira, seus montantes serão convertidos em moeda Argentina, utilizando-se o tipo de câmbio do momento da mensuração."

\section{2.- BRASIL}

O conceito de estoques de acordo com as Normas Brasileiras de Contabilidade - Técnicas NBC - T, aprovadas pelo CFC - NBC - T3, é o seguinte:

"São os valores correspondentes às existências de produtos acabados, produtos em elaboração, matérias-primas, mercadorias, materiais de consumo, serviços em andamento e outros valores relacionados com as atividades da entidade". 


\section{a) Conselho Federal de Contabilidade - CFC $^{10}$}

De acordo com a NBC T 4 - Da Avaliação Patrimonial estabelece-se:

"4.2.3.1 Os estoques de mercadorias, matérias-primas, outros materiais e componentes são avaliados pelo custo de aquisição, atualizados monetariamente, ou pelo valor de mercado, quando este for menor.

4.2.3.2 Os estoques de produtos acabados e em elaboração e os serviços em andamento são avaliados pelo custo de produção, atualizado monetariamente, ou valor de mercado quando este for menor.

4.2.3.3 Os estoques obsoletos ou inservíveis são avaliados pelo valor líquido de realização e os estoques invendáveis devem ser baixados.

4.2.3.4 Os estoques de animais e de produtos agrícolas e extrativos, destinados à venda, poderão ser avaliados pelo valor de mercado, quando atendidas as seguintes condições:

a. que a atividade seja primária;

b. que o custo de produção seja de difícil determinação;

c. que haja um efetivo mercado que possibilite a liquidez imediata desse estoque e que valide a formação do seu preço;

\footnotetext{
${ }^{10}$ CFC. Princípios Fundamentais de Contabilidade e normas brasileiras de Contabilidade. São Paulo, 1995.
} 
d. que seja possível estimar o montante das despesas de realização da venda."

\section{b) Lei das Sociedades por Ações ${ }^{11}$}

No seu art. 183, item II, a Lei $n^{0} 6.404 / 76$, alterada pela Lei $n^{0} 9.457$ de 5 de maio de 1997, diz o seguinte:

"Art. 183 - No balanço, os elementos do ativo serão avaliados segundo os seguintes critérios:"

"II - Os direitos que tiverem por objeto mercadorias e produtos do comércio da companhia, assim como matérias-primas, produtos em fabricação e bens em almoxarifado, pelo custo de aquisição ou produção, deduzido de provisão para ajustá-lo ao valor de mercado, quando este for inferior.

$\S 1^{0}$ Para efeitos do disposto neste artigo, considera-se valor de mercado:

a. das matérias-primas e dos bens em almoxarifado, o preço pelo qual possam ser repostos, mediante compra no mercado;

b. dos bens ou direitos destinados à venda, o preço líquido de realização mediante venda no mercado, deduzidos os impostos e demais despesas necessárias para a venda, e a margem de lucro."

\footnotetext{
${ }^{11}$ Lei № 6.404 de 15 de dezembro de 1976 alterada pela Lei 꾸 9.457 de 5 de maio de 1997. Brasília, 1997. p.269-270.
} 
"§ $4^{\underline{0}}$ Os estoques de mercadorias fungíveis destinadas à venda poderão ser avaliados pelo valor de mercado, quando esse for o costume mercantil aceito pela técnica contábil”.

\section{c) Comissão de Valores Mobiliário - $\mathrm{CVM}^{12}$}

Os critérios da CVM expressos através do Ofício Circular CVM/PTE/578/85 item 1, e do Ofício Circular CVM/309/86 item 8, estão de acordo com o art. 183 da Lei $n^{0} 6.404 / 76$. Nos seus itens 5 e 15 dos citados Ofícios, concordam também em que as despesas financeiras não podem ser ativadas no estoque.

\section{c) Instituto Brasileiro de Contadores - IBRACON ${ }^{13}$}

De acordo com o texto revisado e atualizado da NPC 02 em abril de 1999, a definição de estoques é:

"são ativos tangíveis (ou aplicações de recursos visando a sua obtenção); (i) mantidos para venda no curso dos negócios da entidade, (ii) em processo de produção para posterior venda no curso dos negócios da entidade; e (iii) materiais ou suprimentos a serem consumidos no processo de produção ou na prestação de serviços que constitua exploração de negócios da entidade.”

Este Pronunciamento não se aplica aos estoques de produtos de exploração agrícola, pecuária e florestal e de indústrias extrativas, nem a produtos e serviços executados sob contrato, nem a bens de desgaste a longo prazo. Não

\footnotetext{
${ }^{12}$ Da Rosa, Paulo. A Contabilidade no Mercosul. São Paulo, 1999. p. 103.

${ }^{13}$ IOB. Temática Contábil e Balanços. Normas e Procedimentos de Contabilidade do IBRACON - NPC

02 Estoques - Texto revisado e atualizado em 1999. São Paulo, 1999. p. 6-8.
} 
são incluídos mercadorias adquiridas, ainda em trânsito, estoques que têm a propriedade transferida após sua aprovação, e estoques recebidos em consignação sem responsabilidade.

\section{Custo é:}

"a soma dos gastos incorridos e necessários para a aquisição, conversão e outros procedimentos necessários para trazer os estoques à sua condição e localização atuais, e compreende todos os gastos incorridos na sua aquisição ou produção, de modo a colocá-los em condições de serem vendidos, transformados, utilizados na elaboração de produtos ou na prestação de serviços que façam parte do objeto social da entidade, ou realizados de qualquer outra forma".

Valor líquido de realização "é o preço estimado de venda no curso dos negócios da entidade, deduzidos os custos necessários para completar o produto e aqueles necessários para efetuar a venda ou dela decorrentes (impostos, descontos comerciais, comissões, etc.)

Segundo esta norma, os critérios de avaliação são os seguintes:

"Princípio Básico de Reconhecimento Contábil

10 - O principal critério para avaliação dos estoques é o do custo ou valor líquido de realização, o que for menor, o qual consiste em utilizar o menor entre os valores do custo de aquisição ou produção e o valor líquido de realização, para ser atribuído às unidades em estoque na entidade. 
11 - O conceito de custo, conforme aplicado a estoques produzidos na entidade, é entendido como sendo o somatório dos gastos com matéria-prima, mão de obra direta e outros gastos fabris (mão de obra indireta, energia, depreciação, etc.), excluídos aqueles atribuíveis à ocorrência de fatores não previsíveis, tais como efeitos de ociosidade e de perdas anormais de produção. Gastos gerais e administrativos, quando não claramente relacionados com a produção não são incorporados ao custo dos estoques.

12 - Impostos sobre circulação de mercadorias, sobre produtos industrializados ou quaisquer outros que forem incluídos no preço da mercadoria adquirida, mas que ao mesmo tempo gerarem direito de crédito tributário para compensação, restituição ou qualquer outra forma de recuperação futura, não se constituem em custo e, portanto, não devem ser agregados ao valor dos estoques. Os créditos tributários (ICMS-IPI) quando não forem recuperáveis devem ser incluídos no custeio dos estoques.

13 - Os valores pagos adiantadamente a fornecedores de materiais que irão compor os estoques são considerados como aplicação de recursos visando à formação de estoques futuros, e como tal devem ser registrados.

14 - Determinados itens do estoque podem ser resultantes de compras com preço a fixar. Nesses casos é geralmente aceita a contabilização pelo custo estimado até que seja fixado o preço efetivo. 
Mensuração Inicial

15 - Ao serem adquiridos, as matérias-primas, materiais de natureza diversa, componentes, subprodutos e produtos acabados ou em processo deverão ser avaliados pelo seu custo de aquisição ou produção, de acordo com a respectiva documentação de compra ou de produção, deduzido dos impostos pagos na aquisição e que resultem em créditos efetivos a serem abatidos dos impostos a pagar sobre as saídas de produtos tributados por esses mesmos impostos (ver item 12).

\section{Mensurações Posteriores}

16 - Durante a permanência dos itens classificados nos estoques da entidade, podem ocorrer circunstâncias que levem à necessidade de modificar a base de sua avaliação, como mencionado nos parágrafos seguintes desta seção.

17 - Embora o custo seja o critério principal de avaliação dos estoques, pode ocorrer perda de utilidade ou redução no preço de venda ou de reposição de um item, que reduza o seu valor recuperável a um nível abaixo do custo. Nesse caso, deve-se assumir como base final de avaliação tal valor líquido de realização, caso este seja inferior ao de custo, mediante constituição de provisão.

18 - As perdas comprovadas ou prováveis de determinados itens que, em função do tempo, do avanço tecnológico ou de outros fatores, tenham se tornado ou possam tornar-se obsoletos ou deteriorados, devem ser objeto de ajuste por provisão. Nesses casos devem ser avaliados pelo seu valor líquido de realização. 
19 - Nos casos em que há evidência de que o valor líquido de realização das mercadorias, pela sua venda durante o curso normal dos negócios, será inferior ao de custo - seja devido à deterioração, à obsolescência, a mudanças de níveis de preços, ou a outras causas - essa diferença deve ser reconhecida como encargo do exercício, a débito do custo dos produtos (ou mercadorias) vendidos.

20 - Reduzir o custo de um bem de estoque somente até o valor de mercado não é adequado, quando de, antemão, pode-se estimar que o preço líquido esperado de venda no futuro, menos os custos do conclusão e disposição do bem, é inferior a esse valor de mercado na data do balanço. Não é correto transferir para o período seguinte uma parcela do prejuízo na realização do bem já conhecido na data do balanço.

21 - O custo da matéria-prima não deve ser reduzido ao de reposição, se este for mas baixo, nos casos em que o custo final do produto destinado à comercialização for inferior ao valor líquido de realização.

22 - As reduções de estoques a valores inferiores ao custo, conforme tratadas neste Pronunciamento, devem ser computadas separadamente para cada item individual ou grupos de itens similares, conforme seja mais apropriado. De qualquer forma, esse cômputo não deve ser efetuado por classes inteiras de estoques, classes inteiras de produtos ou qualquer base global, pois, dessa forma, poderia estar-se compensando perdas conhecidas e calculáveis com ganhos não realizados. 
35 - Os métodos mais utilizados na avaliação dos estoques são os seguintes:

(a) custo médio;

(b) primeiro a entrar, primeiro a sair (PEPS);

(c) identificação específica;

(d) custo-padrão (ajustado de acordo com o item 37); e

(e) método do varejo.

36 - Métodos tais como "próximo a entrar, primeiro a sair", ou da última compra fundamentam-se, principalmente, em custos de reposição, que geralmente ocasionam superavaliação dos estoques pela diferença entre o custo efetivo de aquisição ou fabricação e o valor corrente, contrariando o conceito de custo como critério básico de avaliação dos estoques.

37 - Custos-padrão são também aceitáveis se revisados e reajustados periodicamente, sempre que ocorrem alterações significativas nos custos dos materiais, dos salários, ou no próprio processo de fabricação, de forma a refletir as condições correntes. Na data do balanço, o custo-padrão deve ser ajustado ao real.

38 - O método do varejo consiste em avaliar os estoques pela aplicação, sobre seu preço de venda, de percentual que represente a relação média do período entre custo/preço. O método do varejo é utilizado, geralmente, por entidades que comercializem grande número de itens, como supermercados, 
magazines, etc., onde é impraticável o controle permanente dos estoques ou onde a relação custo-benefício desse controle é desfavorável”.

\section{e) Fisco}

De acordo com o Regulamento do Imposto de Renda de 1980, no art. 185, as mercadorias, as matérias-primas e os bens em almoxarifado devem ser avaliados pelo custo de aquisição.

O custo médio ponderado móvel e o Peps serão utilizados quando a entidade possuir inventário permanente. Não ocorrendo isso, somente será aceitável o Peps. (Parecer Normativo CST no 06/76). ${ }^{14}$

\section{3.- COLÔMBIA ${ }^{15}$}

Na Colômbia a definição de estoques é de acordo com o D.R. 2649/93 a seguinte:

"ART. 63 - Os estoques representam bens tangíveis destinados à venda no decorrer dos negócios, assim como aqueles bens que estão em processo de produção ou que serão consumidos na produção de outros bens que depois serão vendidos.

O valor dos estoques, o qual inclui todas as despesas diretas e indiretas necessárias para colocá-los em condições de utilização ou venda, deve ser

\footnotetext{
${ }^{14}$ Fipecafi e Arthur Andersen apud Da Rosa, Paulo. A Contabilidade no Mercosul. São Paulo, 1999. p. 104.

${ }^{15}$ Régimen Contable Colombiano. Bogotá, 1996. p. 263 - 285.
} 
determinado usando-se o método PEPS (primeiro a entrar, primeiro a sair), UEPS (último a entrar, primeiro a sair), o método de identificação específica ou o método médio ponderado. Normas especiais podem autorizar a utilização de outros métodos de reconhecido valor técnico."

No final do período devem reconhecer-se as contingências de perda do valor ajustado dos estoques, mediante as provisões necessárias para ajustá-los a seu valor líquido de realização.

O art. 10, inc. 4, define o valor líquido de realização como: "O valor de realização ou de mercado representa o montante em dinheiro, ou em seu equivalente, em que será realizado um ativo ou liquidado um passivo, no decorrer dos negócios. Valor líquido de realização é o valor de mercado deduzidas as despesas necessárias pela realização do ativo ou a liquidação do passivo, como comissões, impostos, transporte."

"O art. 450, inc. 3ํairma que os estoques serão avaliados de acordo com os métodos permitidos pela legislação fiscal.

A avaliação é o método escolhido para se obter o custo unitário e conseguir o custo de vendas e o estoque diante de possíveis diferenças no valor de inventários fisicamente homogêneos. São três os métodos de avaliação:

a) UEPS ou LIFO: último a entrar, primeiro a sair;

b) PEPS, ou FIFO: primeiro a entrar, primeiro a sair; 
c) CUSTO MÉDIO: soma do valor do estoque inicial mais os valores das entradas, dividido pelo total de unidades em estoque. Cada unidade é tomada pelo valor médio assim obtido.

Devido à Lei não haver determinado nem limitado os métodos de avaliação de estoques, o usuário pode usar qualquer método sem necessidade de autorização da Direção de Impostos Nacionais.

Outros métodos de avaliação são: o Método de identificação específica, Método por varejo, o Método da receita bruta."

O art. 62 fala sobre os sistemas para estabelecer o custo dos ativos vendidos. São:

1. O conjunto de estoques

2. O estoque permanente ou contínuo

3. Outro sistema de reconhecido valor técnico, autorizado pela Direção Geral de Impostos Nacionais.

Para a determinação do Imposto sobre a Renda somente são permitidos o estoque permanente ou contínuo ou outro sistema de reconhecido valor técnico, mas não o conjunto de estoques. O sistema de estoque permanente não requer autorização.

Os contribuintes que determinem os custos de vendas pelo sistema de estoques permanentes ou contínuos deverão levar o controle das mercadorias em folhas especiais, e terão os seguintes dados; 
a) Classe de artigo;

b) Data da operação;

c) Número do documento da operação;

d) Número de unidades compradas, vendidas, consumidas ou trasladadas;

e) Estoques;

f) Custo do comprado, vendido, consumido, etc., e

g) Custo dos estoques.

Os estoques devem ser registrados ao final de cada exercício, de acordo com as seguintes regras:

a) No livro de estoques deve registrar-se uma relação dos estoques, com indicação do número de unidades, o custo unitário e o custo total, e

b) Quando a quantidade e diversidade de artigos dificultar seu registro no livro de estoques, poderá registrar-se neste um resumo por grupos ou classes de artigos, com indicação dos números das folhas ou outros documentos, como folhas soltas devidamente numeradas ou carimbadas pela administração, onde apareça a relação pormenorizada dos estoques.

Nas plantações agrícolas, de acordo com o art. 65, o estoque permanente controla suas existências e custos, utilizando-se um sistema de amortização dependente de seu ciclo agronômico, e não há necessidade de que o sistema de estoque exija um controle por unidades.

Segundo o art. $4^{0}$, o valor do estoque no final do exercício, antes de descontar as provisões para sua proteção e outras de natureza contábil, que não 
são dedutíveis de acordo com as normas gerais, deve coincidir com o valor total registrado nos livros de contabilidade e na respectiva declaração de renda."

\section{4.- PERU}

De acordo com o Plano Contábil Geral Revisado"16 "a Classe 2 Estoques compreende os bens de propriedade da empresa, destinados à fabricação de seus produtos, ao consumo, à manutenção de seus serviços, ou à venda, compreendendo também a provisão para desvalorização de estoques. A classe 2 agrupa as contas da 20 até a 29.

A conta 20, Estoques, agrupa as contas divisionárias que representam os bens adquiridos pela empresa para serem destinados à venda, sem utilizá-los em processo de transformação.

Os estoques devem ser registrados a seu custo de aquisição, que inclui também o preço líquido dado pelo fornecedor, os fretes, seguros, despesas, gastos, direitos de importação e todas as despesas necessárias até que os estoques ingressem no armazém da empresa.

As diferenças de câmbio originadas por passivos em moeda estrangeira plenamente identificáveis com estoques, na data do balanço patrimonial, deverão ajustar o valor líquido deles.

\footnotetext{
${ }^{16}$ Ruedas, Gregório. Plan Contable General Revisado. Lima, 1999. p. 61 - 71.
} 
O movimento de saída dos estoques poderá ser realizado à escolha da empresa, aplicando o método de avaliação mais adequado e tomando em consideração as disposições sobre o particular. No Peru somente são permitidos os métodos PEPS (primeiras entradas, primeiras saídas) e o método médio ponderado.

$\mathrm{Na}$ avaliação dos estoques no final do exercício, deve considerar-se como base o "custo de aquisição ou mercado, o mais baixo". Se este valor fosse menor que o valor em livros, a diferença deve ser aprovisionada, utilizando-se a conta 29 - Provisão para Desvalorização de Estoques.

A conta 21 - Produtos Terminados agrupa as contas divisionárias que representam os bens fabricados pela empresa. Os produtos terminados devem ser registrados ao custo de fabricação segundo o sistema de custo que adote a empresa. O movimento de saída será à escolha da empresa, aplicando o método mais adequado.

$\mathrm{Na}$ avaliação dos produtos terminados no fim do exercício, deve considerarse como base o "custo de produção ou de mercado, o mais baixo". Se este valor é menor que o valor em livros, a diferença deve ser aprovisionada.

A conta 22, Subprodutos, Resíduos e Desperdícios, agrupa as contas divisionárias que representam os produtos acessórios obtidos com a fabricação de outro que constitui a base da fabricação, e também compreende os resíduos de toda natureza, produtos fabricados ou fabricados parcialmente, que não correspondem a uma utilização ou a uma saída normal. 
Os subprodutos, resíduos e desperdícios devem ser registrados ao preço de mercado menos o custo de comercialização. Na avaliação desta conta deve considerar-se como base o "preço de mercado". Se este valor é menor que o valor em livros, a diferença deve ser aprovisionada.

A conta 23 - Produtos em Processo agrupa as contas divisionárias que representam os bens que não chegaram a seu estado definitivo no processo produtivo. Os produtos em processo devem ser registrados ao custo de fabricação equivalente ao grau de elaboração em que está no fim do exercício.

A conta 24 Matérias Primas e Auxiliares agrupa as contas divisionárias que representam os produtos básicos e auxiliares que participam nos processos de fabricação para a obtenção dos produtos terminados. As matérias-primas e os materiais auxiliares devem ser registrados a seu custo de aquisição, que inclui o preço líquido do fornecedor, os fretes, seguros, despesas, direitos de importação, e todas as despesas necessárias até que as matérias-primas ingressem na empresa. O movimento de saída é à escolha da empresa, aplicando-se o método mais adequado. Na avaliação das matérias-primas, no fim do exercício toma-se como base o "custo de aquisição (ou produção) ou mercado, o mais baixo". Se este valor é menor que o valor em livros, a diferença deve ser aprovisionada.

A conta 25, Embalagens, agrupa as contas divisionárias que representam os bens complementares para a apresentação e comercialização do produto. Seu registro e avaliação são semelhantes à conta 24 Matérias primas e auxiliares. 
A conta 26, Fornecimentos Diversos agrupa as contas divisionárias que representam objetos e substâncias que são consumidas e que participam no tratamento, fabricação, e que não participam da composição dos produtos terminados. São os combustíveis, lubrificantes, objetos de escritório, etc. Seu registro e avaliação são semelhantes que a conta 24, Matérias Primas.

A conta 28, Estoques a Receber, agrupa as contas que representam bens cujo ingresso aos armazéns da empresa ainda não foi realizado, e que serão destinados à fabricação de seus produtos, ao consumo, manutenção de seus serviços, ou à venda quando disponíveis.

Os estoques a receber do exterior devem ser registrados quando for realizada a transferência de propriedade dos bens, de acordo com os termos do contrato ou pedido (FAS, FOB, CIF, etc.).

A conta 29 Provisão para Desvalorização de Estoques, agrupa as contas que acumulam as provisões para cobrir a desvalorização de estoques."

\section{Ajuste pela Inflação ${ }^{17}$}

As normas que regulamentam o ajuste das Demonstrações Financeiras por efeitos da inflação são as Resoluções №․ 2 e 3 do Conselho Normativo de Contabilidade desde 1992. Outras normas são o D. Legislativo 797 do 31.12 .95 e seu Regulamento Decreto Supremo 006-96-EF de 12.01.96, para efeitos fiscais.

\footnotetext{
${ }^{17}$ IVERA Asociados. Impuesto a la Renta, Ajustes por Inflación, Flujos de Efectivo. Lima, 1999. p. 434 436.
} 
De acordo com estas normas, as contas não monetárias são ajustadas por efeitos da inflação.

No Peru, os Estoques são considerados não monetários e, devido a isto, devem ser ajustados pela inflação. Ajusta-se o valor em livros, excluindo as diferenças de câmbio alocadas no estoque.

\section{Procedimentos de atualização}

1) O ajuste pela inflação se faz separadamente para cada conta divisionária do item Estoques. Dentro de cada conta divisionária, o ajuste pode-se fazer por cada um dos bens, ou por grupo de bens de características semelhantes ou por linhas de produtos, ou por uma mistura de bens, grupos ou linhas, sempre que a classificação seja uniforme de período a período.

2) A antiguidade das contas de estoques a receber é estabelecida de acordo com sua identificação específica nos registros contábeis.

A antiguidade das outras contas é estabelecida aplicando-se uniformemente, de período a período, os seguintes critérios:

a) A antiguidade específica de cada uma, de acordo com os registros contábeis.

b) Pelo Método Global:

Independentemente de que nos livros de contabilidade aplique-se o custo médio, o custo primeiras entradas - primeiras saídas ou o custo específico como 
método de avaliação de estoques, assume-se o saldo de cada conta, grupo ou linha estabelecido de acordo com 1) corresponde a uma parte ou ao total das respectivas compras ou custos de produção, do último mês do período, mais os de cada um dos meses sucessivamente anteriores, até esgotá-los. Na aplicação deste critério para as contas de produtos em processo e de produtos terminados, deve-se ter em consideração os itens 3) e 4) seguintes:

3) Deve assumir-se que as últimas compras de estoques, matérias-primas, materiais auxiliares, embalagens e fornecimentos diversos correspondem respectivamente aos saldos dessas contas, até esgotá-los; que as compras imediatamente anteriores àquela correspondem aos valores que, por estes tipos de estoques, estão contidos nos saldos de produtos em processo; e por conseqüência, os valores que por estes tipos de estoques estão contidos nos saldos de produtos terminados, correspondem a compras anteriores às consideradas anteriormente.

4) Para determinar a antiguidade dos componentes dos saldos das contas produtos em processo e produtos terminados, seguindo o critério de 2), assumese que a soma destes saldos corresponde a uma parte ou ao total dos custos de produção do último mês do período, mais os de cada um dos meses sucessivamente anteriores, até onde seja necessário para esgotá-la. Depois de estabelecido o número de meses de produção, representado pelos estoques de produtos em processo e produtos terminados, apura-se os totais de custos incorridos nesses meses por conceito de matérias-primas, materiais auxiliares, embalagens, fornecimentos diversos, depreciação, mão-de-obra e despesas 
gerais de fabricação, e calcula-se a porcentagem de cada um destes conceitos em relação ao total. Assume-se também que essas são as porcentagens dos componentes dos saldos por atualizar de produtos em processo e produtos terminados, determinando assim o monto de cada componente em moeda nacional.

A antiguidade da depreciação é a mesma dos imóveis, maquinarias e equipamento que originam este componente de custos. Nos valores de mão-deobra e despesas gerais de fabricação contidos no saldo de produtos em processo, assume-se que correspondem a uma parte ou ao total dos custos incorridos em cada um dos meses sucessivamente anteriores, até onde seja necessário para esgotá-los; os contidos no saldo de produtos terminados correspondem aos custos incorridos por estes conceitos imediatamente antes dos correspondentes a produtos em processo.

5) Para determinar a composição e antiguidade dos custos de produtos em processo e de produtos terminados, as empresas cujas receitas líquidas anuais sejam inferiores a 1500 unidades impositivas tributárias (UIT) poderão escolher pelos procedimentos descritos anteriormente ou por estimativas de seu departamento técnico de produção, ou por seu sistema de custos predeterminados, se tivera. A UIT que corresponde para este objetivo é a vigente no início do exercício. 


\section{Limite de atualização}

O limite de atualização dos estoques é o mais baixo entre o valor ajustado e o valor de mercado. Para determinar o valor de mercado devem seguir-se os seguintes critérios:

a) As estimativas de valor líquido realizável não devem basear-se em flutuações temporais de preços ou custos, mas sim nas evidências mais confiáveis disponíveis.

b) $\quad$ valor líquido realizável dos estoques que se tenham para atender compromissos de venda fixados deve basear-se nos preços fixados. $O$ valor líquido realizável dos estoques não comprometidos deve basear-se nos preços de venda aplicáveis a outros compradores não ligados a compromissos de venda.

c) As quantidades normais de matérias-primas, materiais auxiliares, embalagens e fornecimentos diversos que se tenham para a produção de artigos não devem ser avaliados abaixo de seu custo atualizado, esperando-se que os produtos terminados nos quais serão incorporados possam ser realizados ao custo atualizado ou a preços maiores.

Não obstante, se uma baixa nos preços indicar que o custo dos artigos por produzir excede o valor líquido realizável, deve-se reduzir o custo atualizado, e o custo de reposição poderá ser a melhor medida disponível do valor de mercado desses estoques. 
d) Por razões práticas, pode-se limitar a atualização dos estoques comprados ao valor de reposição, sempre que este seja menor que uma estimativa razoável do valor líquido realizável.

e) Em todos os casos onde seja aplicado o valor de mercado, considera-se prova suficiente a cotação do fornecedor cuja nota foi utilizada para determinar o custo de reposição ou os cálculos de valor líquido realizável sustentados em papéis de trabalho e com valores de venda comprovados por documento.

f) A redução dos inventários ao valor líquido realizável deve ser feita por cada um dos bens ou por grupos de bens semelhantes. Qualquer destes dois métodos deve ser aplicado uniformemente de período a período."

Para efeitos tributários, a partir do exercício 1996, o ajuste por inflação tem no caso dos estoques, como limite, o Valor de Reposição, que em nenhum caso poderá ser menor que os respectivos valores de aquisição ou de entrada no patrimônio. O valor de reposição é o custo do produto na data de atualização para repor um ativo por compra ou reprodução, conforme o caso. A determinação do valor de reposição deve ser apoiada por notas de pagamento do mesmo tipo de bens, emitidas durante o mês correspondente à atualização. 


\section{5.- VENEZUELA}

A Declaração de Princípios de Contabilidade (DPC-10), que normatiza a correção monetária na Venezuela, em seus parágrafos 39 e 40 estabelece o seguinte em relação aos estoques: ${ }^{18}$

"39. No método do Nível Geral de Preços, determina-se a data de origem por categorias, agrupando os itens por mês, período do ano, ou ano de origem, segundo seja conveniente.

40. O valor ajustado por índices de preços está sujeito à norma do menor entre o custo ajustado e o valor recuperável.

Os estoques representam um dos mais importantes itens que são mostrados nas Demonstrações Financeiras de empresas de fabricação. Para analisar o impacto que pode ter cada um dos métodos de avaliação na correção monetária, devem considerar-se os diferentes métodos de avaliação aplicáveis.

- Método Médio: dividido em:

- Médio Simples

- Médio Ponderado

- Médio Móvel dividido em:

- Médio Simples

- Médio Ponderado

- Médio Móvel

\footnotetext{
${ }^{18}$ Catacora, Fernando Carpio. Op. Citada. Caracas, 1999.
} 
- Método Peps: primeiro a entrar, primeiro a sair.

- Método Ueps: último a entrar, primeiro a sair.

- Método de Identificação Específica." 


\section{3.- I NVESTI MENTOS PERMANENTES}

\section{1.-ARGENTINA}

a) Federação Argentina de Conselhos Profissionais de Ciências Econômicas - FACPCE ${ }^{19}$

"Na Argentina, de acordo com as Resoluções Técnicas (RT)nํ 8 e 9 da Federação Argentina de Conselhos Profissionais de Ciências Econômicas, os Investimentos a Longo Prazo são aplicações com prazo maior de 12 meses efetuadas com o objetivo de obter renda ou outro benefício que não fazem parte da estrutura comercial, industrial ou de serviços da empresa. Incluem, entre outros valores, as participações em outras empresas, sociedades controladas e coligadas, imóveis e propriedades.

Os Investimentos Permanentes são registrados no Ativo não Corrente em Investimentos em Longo Prazo.

Os procedimentos de avaliação dos investimentos em controladas e coligadas são normatizados pela Resolução Técnica $n^{0} 5$, que foi modificada pela $\mathrm{RT} \mathrm{n}^{0} 19$ da seguinte forma:

Novo título da RT $n^{0}$ 5: Mensuração contábil de participações permanentes em sociedades sobre as quais há controle, controle conjunto ou influência significativa.

\footnotetext{
${ }^{19}$ http://www.facpce.com.ar/
} 
A mensuração contábil das participações em entidades sobre os que se tenha controle, controle conjunto ou influência significativa deve fazer-se considerando a mensuração de seus patrimônios e as porcentagens de participação sobre eles.

\section{Controle}

O controle é exercido quando se possui participação que por qualquer título outorgue os votos necessários para formar a vontade social nas reuniões sociais ou assembléias (Artigo 33, inc. $1^{0}$ da lei 19.550).

Para os fins destas normas, considera-se que contar com os votos necessários para formar a vontade social implica possuir mais do $50 \%$ dos votos possíveis, em forma direta ou indireta, na data de fechamento do exercício da sociedade controladora.

\section{Controle conjunto}

Para os fins desta RT existe controle conjunto quando os sócios de uma entidade decidiram compartilhar as decisões sobre as normas operacionais e financeiras. Um sócio exerce controle conjunto em uma entidade, quando as decisões mencionadas necessitam de seu consentimento.

Nota: O controle conjunto é o único item incorporado pela RT $\mathrm{n}^{\underline{0}} 19$ para aplicar-se o método de Participação Patrimonial. 


\section{Influência significativa}

Para exercer influência significativa deve-se considerar:

a) a posse por parte da empresa detentora de uma participação tal da sociedade coligada que outorgue os votos necessários para influir na aprovação de suas demonstrações contábeis e na distribuição de lucros;

b) a representação na diretoria ou órgãos administrativos superiores, na sociedade coligada;

c) a participação na fixação de políticas;

d) a existência de operações importantes entre a sociedade investidora e a coligada (por exemplo, se é o único fornecedor/cliente ou o mais importante, com uma diferença significativa sobre o restante).

e) o intercâmbio de executivos em nível de direção;

f) a dependência técnica de uma das sociedades em relação à outra.

Ao proceder à mencionada avaliação, deve-se também considerar:

a. a forma como é distribuído o resto do capital (maior ou menor concentração em mãos de outros investidores);

b. a existência de acordos ou situações (intervenções, concordatas e outras) que poderiam outorgar a direção a algum grupo minoritário. 


\section{Valor patrimonial proporcional}

Considera-se valor patrimonial proporcional ao resultante de aplicar no patrimônio líquido da sociedade coligada a proporção do número de ações que corresponde à empresa investidora.

Quando a sociedade emissora tiver classes de ações em circulação que outorguem diferentes direitos patrimoniais, o cálculo deverá ser feito separadamente para cada uma delas, sobre a base de suas condições de emissão.

\section{Requisitos para a aplicação do método}

O método do valor patrimonial proporcional deve aplicar-se sobre demonstrações financeiras da sociedade emissora que sejam preparadas de acordo com:

a) as normas contábeis vigentes utilizadas pela empresa investidora, quando a sociedade emissora for uma sociedade controlada;

b) normas contábeis vigentes, nos demais casos.

Quando o exercício econômico da sociedade emissora finalize em data diferente ao da empresa investidora, o método será aplicado sobre demonstrações contábeis especiais da sociedade emissora na data de fechamento da empresa investidora. 
Não obstante, poderá optar-se pela utilização das demonstrações contábeis da sociedade emissora na sua data de fechamento quando a diferença entre ambos fechamentos não seja maior que três meses. Neste caso vão se considerar os ajustes correspondentes, para refletir os efeitos de qualquer evento significativo ou operações entre a sociedade emissora e a empresa investidora que ocorreram nesse período. Também vão considerar-se as mudanças no poder aquisitivo da moeda Argentina, de acordo com o previsto na seção 3.1 da segunda parte da RT $\mathrm{n}^{0} 17$.

Os investimentos que não cumpram os requisitos de controle, controle conjunto ou influência significativa, serão avaliados pelo custo".

\section{"b) Comissão Nacional de Valores - CNV}

A CNV não aceita a defasagem de datas de encerramento do exercício social se a investida for uma empresa de capital aberto"20.

\section{2.- BRASIL}

No Brasil, de acordo com as Normas Brasileiras de Contabilidades Técnicas do CFC - NBC - T-3: "os investimentos permanentes são as participações em sociedades e os bens e direitos que não se destinem à manutenção das atividades - fins da entidade".

\footnotetext{
${ }^{20}$ Da Rosa, Paulo Moreira. Op. Citada. São Paulo, 1999. p. 116.
} 
Os Investimentos permanentes são registrados no grupo Ativo Permanente devido a terem sido adquiridos com a intenção de permanência.

Os órgãos que ditam as normas sobre os investimentos permanentes são:

\section{a) O Conselho Federal de Contabilidade - CFC $^{21}$}

A NBC-T-4 - Da Avaliação Patrimonial: dispõe o seguinte:

“4.2.6.1 - Os investimentos permanentes são avaliados pelo custo de aquisição, atualizado monetariamente, ou com base no valor de patrimônio líquido.

4.2.6.2 - São avaliados com base no valor de patrimônio líquido:

a. o investimento relevante em cada coligada, quando a investidora tem influência na administração ou quando a porcentagem de participação da investidora representa $20 \%$ (vinte por cento) ou mais do capital social da coligada;

b. os investimentos em cada controlada;

c. os investimentos em coligadas e/ou controladas, cujo valor contábil seja, em conjunto, igual ou superior a 15\% (quinze por cento) do patrimônio líquido da investidora.

Parágrafo único. Os conceitos de empresas coligadas, controladas e de relevância de investimentos são aqueles estabelecidos pela legislação societária.

\footnotetext{
${ }^{21}$ CFC. Princípios Fundamentais de Contabilidade e Normas Brasileiras de Contabilidade. São Paulo, 1995.
} 
4.2.6.3 - O custo de aquisição de investimento em coligada e/ou controlada é desdobrado em:

a) valor de patrimônio líquido baseado em balanço patrimonial levantado no prazo da legislação societária;

b) ágio e deságio na aquisição, representado pela diferença para mais ou menos, respectivamente, entre o custo de aquisição do investimento e o valor de patrimônio líquido, que serão amortizados com base em sua fundamentação econômica.

4.2.6.4 - As provisões para perdas no valor dos investimentos são constituídas com base em perdas efetivas ou potenciais.

4.2.6.5 - O valor dos investimentos não é modificado em razão do recebimento, sem custo, de ações e quotas bonificadas."

A Resolução CFC № 846/99, de 25 de maio de 1999, dispõe sobre a alteração do item 4.2.6.4 da alteração do item 4.2.6.4 da NBC-T-4 da avaliação patrimonial: ${ }^{22}$

“4.2.6.4 - As provisões para perdas no valor dos investimentos são constituídas com base em perdas potenciais".

\footnotetext{
${ }^{22}$ http://www.cfc.org.br/
} 


\section{b) Lei das Sociedades por Ações}

Os investimentos permanentes podem ser contabilizados pelo custo de aquisição ou pelo valor de patrimônio líquido (método da equivalência patrimonial).

No seu art. 183, item III, a Lei $n^{0} 6.404 / 76$ alterada pela Lei $n^{0} 9.457$ de 5 de maio de 1997 dispõe sobre a avaliação dos investimentos:

23“III - os investimentos em participação no capital social de outras sociedades, ressalvado o disposto nos Art. 248 a 250, pelo custo de aquisição, deduzido de provisão para perdas prováveis na realização do seu valor, quando essa perda estiver comprovada como permanente, e que não será modificado em razão do recebimento, sem custo para a companhia, de ações ou quotas bonificadas."

Isto significa que os investimentos permanentes serão registrados pelo custo de aquisição e sujeitos à avaliação pelo valor de mercado, se este for inferior àquele quando não cumpram os requisitos exigidos pelos Art. 248 a 250 .

24“Art. 248 - No balanço patrimonial da companhia, os investimentos relevantes (Art. 247, parágrafo único) em sociedades coligadas sobre cuja administração tenha influência, ou de que participe com $20 \%$ (vinte por cento) ou mais do capital social, e em sociedades controladas, serão avaliados pelo valor de patrimônio líquido, de acordo com as seguintes normas:

\footnotetext{
${ }^{23}$ Lei № 6.404 de 15 de dezembro de 1976 alterada pela Lei $n^{0} 9.457$ de 5 de maio de 1997. Brasília, 1997. p. 270 .

${ }^{24}$ Lei № 6.404 de 15 dezembro de 1976 alterada pela Lei no 9.457 de 5 de maio de 1997. Brasília, 1997. p.285 $-287$.
} 
I - o valor do patrimônio líquido da coligada ou da controlada será determinado com base em balanço patrimonial ou balancete de verificação levantado, com observância das normas desta Lei, na mesma data, ou até 60 (sessenta) dias, no máximo, antes da data do balanço da companhia; no valor de patrimônio líquido não serão computados os resultados não realizados decorrentes de negócios com a companhia, ou com outras sociedades coligadas à companhia, ou por ela controladas;

II - o valor do investimento será determinado mediante a aplicação, sobre o valor de patrimônio líquido referido no número anterior, da porcentagem de participação no capital da coligada ou controlada;

III - a diferença entre o valor do investimento, de acordo com o número II, e o custo de aquisição corrigido monetariamente, somente será registrada como resultado do exercício:

a) se decorrer de lucro ou prejuízo apurado na coligada ou controlada;

b) se corresponder, comprovadamente, a ganhos ou perdas efetivos;

c) no caso de companhia aberta, com observância das normas expedidas pela Comissão de Valores Mobiliários.

$\S 1^{0}$ - Para efeito de determinar a relevância do investimento, nos casos deste artigo, serão computados como parte do custo de aquisição os saldos de créditos da companhia contra as coligadas e controladas. 
$\S 2^{\underline{0}}-$ A sociedade coligada, sempre que solicitada pela companhia, deverá elaborar e fornecer o balanço ou balancete de verificação previsto no número I."

Os conceitos de coligadas e controladas são definidos no Art. 243:

“§ $1^{\underline{0}}$ - São coligadas as sociedades quando uma participa, com 10\% (dez por cento) ou mais, do capital da outra, sem controlá-la.

$\S 2^{0}$ - Considera-se controlada a sociedade na qual a controladora, diretamente ou através de outras controladas, é titular de direitos de sócio que lhe assegurem, de modo permanente, preponderância nas deliberações sociais e o poder de eleger a maioria dos administradores."

O conceito de relevante é definido no Art. 247:

"Parágrafo único - Considera-se relevante o investimento:

a) em cada sociedade coligada ou controlada, se o valor contábil é igual ou superior a $10 \%$ (dez por cento) do valor do patrimônio líquido da companhia;

b) no conjunto das sociedades coligadas e controladas, se o valor contábil é igual ou superior a 15\% (quinze por cento) do valor do patrimônio líquido da companhia". 


\section{c) Comissão de Valores Mobiliários - CVM}

De acordo com o IOB, ${ }^{25}$ as companhias abertas e as instituições financeiras devem observar também, no tocante à avaliação de investimentos pelo MEP, as normas pertinentes expedidas pela Comissão de Valores Mobiliários (Instrução $n^{0}$ 01, de 27-4-1978 e Instrução n 247/96) e pelo Banco Central do Brasil, respectivamente, que têm competência legal para, inclusive, estender a aplicação do MEP a outras situações não contempladas na legislação do Imposto de Renda.

A CVM diz que são equiparadas a coligadas as sociedades nas quais a investidora detém $10 \%$ ou mais do capital votante, indiretamente, sem controlá-la.

Além disso, a CVM também considera equiparada à coligada a situação em que uma companhia participa diretamente com $10 \%$ ou mais do seu capital votante (não capital total), mesmo que isso represente menos de $10 \%$ do capital total.

No caso das instituições financeiras autorizadas a funcionar pelo Banco Central e no caso das companhias abertas terem controladas e coligadas, pode ocorrer o seguinte: as controladas serão obrigatoriamente avaliadas pela equivalência patrimonial nessas investidoras, mas pode 0 conjunto de investimentos não ser relevante e haver uma única participação relevante. Se esta for em uma controlada, já estará sendo avaliada pela equivalência. Se for em uma coligada, será aplicada sobre ela essa avaliação à base do valor do seu patrimônio líquido, no caso de ser coligada em que se detenha influência ou pelo 
menos $20 \%$ do seu capital social. Caso o conjunto seja relevante, pela Lei das S/A, ainda é necessário que as coligadas atendam uma das duas condições: mínimo de $20 \%$ de participação ou influência. Mas o Banco Central determina que, nesse caso de conjunto relevante, suas fiscalizadas adotem a equivalência para todas as coligadas.

\section{d) Instituto Brasileiro de Contadores - IBRACON}

Através do Pronunciamento $\mathrm{n}^{0} \mathrm{VI}$ - Investimentos: Participações em Outras Sociedades, o Ibracon dá os lineamentos básicos da avaliação de investimentos em sociedades coligadas e controladas e as participações em outras sociedades de natureza permanente, voluntárias ou decorrentes de incentivos fiscais. Este pronunciamento é baseado na Lei $n^{0}$ 6.404/76, na Instrução CVM nำ 01/78 e na legislação do Imposto de Renda em vigor.

\section{e) $\mathrm{Fisco}^{26}$}

A legislação do Imposto de Renda (art. 384 do RIR/99) manda as pessoas jurídicas avaliarem pelo valor de patrimônio líquido, ou seja, pelo método da equivalência patrimonial (MEP), os investimentos permanentes (participações societárias) enquadrados como relevantes em:

- sociedades controladas;

\footnotetext{
${ }^{25}$ IOB. Temática Contábil e Balanços. Quais Investimentos devem ser avaliados pela Equivalência Patrimonial? (1 parte). 1 Semana - Outubro de 1999 - N. 40 p. 1 - 9.

${ }^{26}$ IOB. Imposto de Renda e Legislação Societária. Investimentos avaliados pela Equivalência Patrimonial. 2 Semana - Junho de 1999 - N 23. p. 1-5.
} 
- sociedades coligadas sobre cuja administração tenham influência ou de que participem com vinte por cento ou mais do capital social.

Os conceitos de coligadas, controladas e relevância dos investimentos são os mesmos da Lei das Sociedades por Ações.

A avaliação de investimentos pelo MEP é obrigatória nas hipóteses acima mencionadas, independentemente do tipo societário (S/A ou limitada) da investidora ou das sociedades coligadas ou controladas.

Os investimentos permanentes não enquadrados nas normas tratadas nos subitens anteriores, devem ser avaliados pelo custo de aquisição, corrigido monetariamente até 31.12 .95 , caso tenham sido adquiridos até essa data, sendo vedada a sua avaliação pelo MEP.

Em síntese, o valor da equivalência patrimonial do investimento é determinado mediante a aplicação, sobre o valor do patrimônio líquido da coligada ou controlada, da porcentagem de participação da investidora no capital social da investida, observando-se que (art. 387 do RIR/99):

a) o valor do patrimônio líquido da coligada ou controlada deve ser determinado com base em balanço patrimonial ou balancete de verificação levantado na mesma data do balanço da investidora ou até dois meses, no máximo, antes dessa data, com observância da lei comercial, inclusive quanto à dedução das participações nos resultados e da provisão para o Imposto de Renda; 
b) se os critérios contábeis adotados pela coligada ou controlada e pela investidora não forem uniformes, a investidora deverá fazer no balanço ou balancete da coligada ou controlada os ajustes necessários para eliminar as diferenças relevantes decorrentes da diversidade de critérios;

c) o balanço ou balancete da coligada ou controlada levantado em data anterior à do balanço da investidora deve ser ajustado para registrar os efeitos relevantes de fatos extraordinários ocorridos no período.

O valor contábil do investimento na data do balanço será ajustado ao valor da sua equivalência patrimonial mediante lançamento da diferença, a débito (se positiva) ou a crédito (se negativa) da conta do investimento, tendo como contrapartida débito ou crédito em conta de resultado (art. 388 do RIR/99).

Na aplicação do MEP devem ser observadas também, quando for o caso, as normas específicas para as companhias abertas, determinadas pela CVM, e para as instituições financeiras, determinadas pelo Banco Central do Brasil.

A lei fiscal determina que a avaliação de investimentos pelo MEP deve ser realizada:

1 - por ocasião da aquisição do investimento, quando deve ser desdobrado o custo de aquisição em (art. 385 do RIR/99):

a) valor da equivalência patrimonial na época da aquisição, determinado de acordo com os procedimentos anteriores; 
b) ágio ou deságio na aquisição, correspondente à diferença entre o custo de aquisição e o valor da equivalência patrimonial, que deverá ser registrado em sub-conta distinta da sub-conta de registro do investimento. Para o lançamento de ágio ou deságio na aquisição do investimento, a lei prescreve o seguinte $\left(\S \S 2^{\underline{0}}\right.$ e $3^{0}$ do art. 385 do $\left.R I R / 99\right)$ :

Deverá ser indicado o seu fundamento econômico, dentre um dos seguintes:

- valor de mercado de bens do ativo da coligada ou controlada superior ou inferior ao custo registrado na sua contabilidade, baseado em demonstrativo que deve ser mantido como comprovante da escrituração;

- valor de rentabilidade da coligada ou controlada, com base em previsão dos resultados nos exercícios futuros, baseado em demonstrativo;

- fundo de comércio, intangíveis e outras razões econômicas;

2 - por ocasião de cada balanço de encerramento de período-base de apuração do lucro real, quando o ajuste do valor do investimento à nova equivalência patrimonial deve ser registrado na forma mencionada.(art. 387 do $\operatorname{rir} / 99)$;

3. por ocasião da alienação do investimento (art. 427 do RIR/99).

A contrapartida do ajuste do valor do investimento à nova equivalência patrimonial, lançada em conta de resultado, não será computada na apuração do 
lucro real (art. 389 do RIR/99), devendo no Livro de Apuração do Lucro Real (LALUR), ser:

a) excluída do lucro líquido, se positiva (receita); ou

b) adicionada ao lucro líquido, se negativa (despesa).

Todavia, ressalve-se que a não tributação de resultados positivos apurados somente se aplica nas hipóteses de avaliação de investimentos pelo MEP expressamente previstas na legislação. Em qualquer outra hipótese, a eventual avaliação do investimento por esse método implica tratar o resultado apurado como reavaliação tributável (PN CST $n^{0}$ 107/78).

\section{3.- COLÔMBIA ${ }^{27}$}

"Os investimentos estão representados em títulos, valores e outros documentos em poder de outras entidades econômicas, conservados com o objetivo de obter rendas fixas ou variáveis, controlar outras entidades ou segurar o relacionamento com eles.

Os investimentos feitos para ser vendidos em um ano denominam-se investimentos temporais. Os outros são os investimentos permanentes.

O valor histórico dos investimentos, após ser corrigido pela inflação, deve ser ajustado no final do período ao valor de realização, através de provisões ou valorizações.

\footnotetext{
${ }^{27}$ Régimen Contable Colombiano. Bogotá, 1996. p.212 - 236.
} 
O valor de realização dos investimentos de renda variável é a média da cotação da bolsa de valores no último mês e, quando não houver esta, seu valor intrínseco.

De acordo com o artigo 61 do Decreto 2649 de 1993, os investimentos em sociedades controladas, onde a entidade econômica possa dispor que no período seguinte Ihe sejam transferidos seus lucros, devem contabilizar-se através do "método de participação", exceto quando os investimentos sejam adquiridos e mantidos com a finalidade de venda em um futuro próximo, nesse caso devem contabilizar-se pelo custo.

A aplicação do método de participação nas demonstrações financeiras da principal não elimina a obrigação de apresentar demonstrações financeiras consolidadas. Os resultados da aplicação do método de participação e da consolidação das demonstrações financeiras devem coincidir. O método de participação deve ser aplicado a partir dos eventos ocorridos no $1^{0}$ de janeiro de 1994.

A partir de 1995 as entidades emissoras de valores que não estejam sujeitas ao controle e vigilância de outra entidade estatal devem seguir as seguintes regras:

1) Definição. "Método de participação" é o procedimento contábil onde uma sociedade registra seu investimento ordinário em outra, que se constitui em sua filial, inicialmente ao custo e posteriormente ajustando-se (aumentando ou diminuindo) pelas mudanças no patrimônio da subordinada subseqüentes a sua 
aquisição e de acordo com a porcentagem de participação. As contrapartidas deste ajuste nas demonstrações financeiras da principal são registradas na demonstração de resultado e/ou na conta de resultados por valorizações, segundo o seguinte:

- As mudanças no patrimônio da filial ocorridas durante o período serão reconhecidas pela principal aumentando ou diminuindo o custo de seu investimento.

- As mudanças no patrimônio da filial que sejam originárias do resultado líquido do exercício afetarão a demonstração de resultados da principal.

- As variações do patrimônio da filial que não sejam originárias de sua demonstração de resultado não afetarão os resultados da principal.

- Os dividendos e participações de uma sociedade, na qual se tem investido, recebidos em caixa, que correspondam a períodos nos quais a sociedade principal aplicou o método de participação, reduzem nesta o valor em livros do investimento.

- O método de participação deve ser aplicado para cada um dos investimentos individualmente.

2) Sociedades subordinadas. São consideradas as filiais ou subsidiárias, segundo termos do estabelecido nos artigos 260 e 261 do Código do Comércio, em concordância com os artigos 26 e 27 da Lei 222 de 1995 e demais normas que 
possam mudá-lo ou substitui-lo. Considera-se subordinada a entidade nos seguintes casos:

- Quando a principal possui mais do $50 \%$ da subordinada, diretamente ou através de suas subordinadas ou das subordinadas destas. Não são consideradas as ações com dividendo preferencial e sem direito a voto.

- Quando a principal e as subordinadas tenham conjunta ou separadamente o direito de emitir votos constitutivos do quorum mínimo decisório na junta de sócios ou na assembléia de acionistas, ou tenham o número de votos necessário para eleger a maioria de membros da junta diretiva.

- Quando a principal, diretamente ou através de subordinadas, por causa de um ato ou negócio com a sociedade controlada ou com seus sócios, exerça influência dominante nas decisões dos órgãos da administração da sociedade.

3) Investimentos sujeitos à avaliação pelo método da participação.

Os investimentos que devem ser avaliados pelo método da participação são os investimentos diretos em filiais, sempre que:

- A principal tenha o poder de dispor que no período seguinte a empresa filial distribua a ela seus lucros.

- A principal não tenha a intenção de vender o investimento no futuro imediato. 
- A filial não tenha nenhuma restrição para a distribuição de seus lucros.

No fim do exercício da principal, ou no fim do mês tomado como base para a preparação das demonstrações financeiras extraordinárias da principal, cada uma das filiais dos emissores de valores deverá avaliar pelo método de participação os investimentos que possua naquelas sociedades que sejam subordinadas de sua principal, porém a respectiva filial individualmente possua menos de $50 \%$ do capital da subsidiária.

As mudanças nas subsidiárias serão refletidas na principal através das filiais. Por este motivo a principal deve indicar as instruções pertinentes para que todas as suas subordinadas apliquem o método de participação e possam se ajustar a um cronograma que permita à principal entregar oportunamente suas demonstrações financeiras.

4) Demonstrações financeiras envolvidas na aplicação do método de participação.

As mudanças no patrimônio da filial são obtidas comparando as demonstrações financeiras do fim do período com as demonstrações financeiras do período anterior.

Se a filial não é obrigada a fechar suas contas na mesma data da principal, deve preparar demonstrações financeiras intermediárias na mesma data de fechamento da principal. 
A principal adotará todas as medidas necessárias para dispor da informação da filial preparada na mesma data de fechamento da principal.

O método de participação deverá ser aplicado pela principal no fechamento do exercício, anual, semestral, ou outro. Se a principal prepara demonstrações financeiras extraordinárias, deverá aplicar o método de participação para a avaliação dos investimentos em filiais no fechamento do mês tomado como referência. A filial deverá preparar demonstrações financeiras intermediárias na mesma data.

Cada uma das filiais aplicará o mesmo procedimento em relação a suas próprias subordinadas.

5) Base do cálculo. A base do cálculo é o patrimônio da subordinada. Desta base devem-se eliminar os lucros ou perdas não realizados originados por operações entre subordinada e principal. Assim subtrai-se do valor atualizado do investimento e da receita por investimento a participação da principal nos lucros ou perdas não realizados.

Lucro ou perda não realizada é aquela que gera a subordinada ao vender à principal, e quando a principal não realizou ainda através de vendas a terceiros.

Não é incluída a participação patrimonial que corresponde ao capital preferencial, ou seja, a aportes com dividendo garantido, como as ações com dividendo preferencial e sem direito ao voto. 
A base depurada dessa forma servirá para aplicar o método de participação aos investimentos em subordinadas.

6) Porcentagem de participação. A porcentagem de participação calcula-se dividindo o capital total possuído pela principal na subordinada, pelo capital total da subordinada, excluindo de ambos o capital preferencial.

7) Ajustes por Inflação. O efeito da aplicação do método de participação é reconhecido no valor dos investimentos em questão, no fechamento do período. Este valor será a base para que no decorrer do período seguinte se continuem realizando os ajustes mensais por inflação.

8) Receitas. As participações ou dividendos recebidos da filial que correspondam a períodos nos quais se aplicou o método de participação, reduzem o custo do investimento se previamente afetaram a ele. Em caso contrário, são reconhecidos como receitas do período no qual se realizam, gerando os ajustes necessários.

9) Perdas. As diminuições no patrimônio da filial reduzem o custo reconhecido pela principal, assim como o saldo das valorizações. Se as perdas superam um e outra, o investimento é zero. Somente são reconhecidas perdas adicionais quando, com base em regras legais, estatutárias ou convencionais, a principal não tenha sua responsabilidade limitada ao montante de seus aportes.

Se posteriormente a filial obtém lucros, a principal reinicia a utilização do método de participação nesses lucros somente depois de que sua participação 
neles seja igual à sua participação nas perdas líquidas não reconhecidas em exercícios anteriores.

10) Divulgações. Com relação aos investimentos em filiais, deverão fazer, como mínimo, as divulgações exigidas nos artigos 15,115 parágrafo 3 e 116 parágrafo 1 do Decreto 2649 de 1993.

$\mathrm{Na}$ demonstração de resultados deverá apresentar-se em colunas separadas os lucros ou perdas, produto da aplicação do método de participação, e em notas explicativas às demonstrações financeiras divulgar estas situações.

11) Procedimento para estabelecer o valor do investimento.

- Determinar os investimentos ordinários que possua a companhia, ou seja, aqueles que não outorgam direitos preferenciais.

- Determinar quais destes investimentos são permanentes.

- Estabelecer sobre quais destes investimentos a entidade econômica tem o poder de dispor que os lucros lhe sejam transferidos, não exista intenção de vender no futuro imediato e não exista nenhuma restrição para a distribuição dos lucros.

- Para cada um dos investimentos sujeitos à aplicação do método de participação, obter a variação patrimonial da subordinada ocorrida durante o exercício. 
- Da variação patrimonial obtida no parágrafo anterior, excluir os lucros e demais contas patrimoniais originadas durante o exercício por operações entre a principal e a filial, assim como a participação patrimonial que corresponda ao capital preferencial, ou seja, a aportes com dividendo garantido, como ações com dividendo preferencial e sem direito ao voto.

- Considerando a porcentagem de participação ordinária que possua a entidade econômica no capital ordinário da subordinada, estabelecer a participação da entidade na variação patrimonial depurada da subordinada.

- O valor assim obtido aumentará ou diminuirá o valor em livros do investimento, conforme a variação seja positiva ou negativa. As mudanças no patrimônio da subordinada que sejam originadas do resultado líquido do exercício serão contabilizadas nas contas de resultado da principal.

- As mudanças no patrimônio da subordinada que não sejam originadas da demonstração de resultados serão contabilizadas na principal como receita por valorizações no grupo 38 do PUC, através de auxiliares específicos, cujos saldos serão ajustados por inflação, devendo constar em notas explicativas das demonstrações financeiras. 
12) Aspectos fiscais. Os lucros e perdas derivados da aplicação do método de participação serão tratados fiscalmente de acordo com as normas aplicadas a cada contribuinte.

Os impostos diferidos originados pelo uso do método de participação serão reconhecidos de acordo com o previsto nos artigos 67 e 78 do Decreto 2649 de 1993.

13) Valor de realização ou mercado. De acordo com o artigo 61 do Decreto 2649 de 1993, os investimentos cujo valor seja determinado pelo método de participação não serão ajustados ao valor de realização ou mercado.

14) Aplicação de outras normas. Quando na aplicação do método de participação apresentam-se situações não contempladas aqui, se poderão aplicar as normas internacionais de contabilidade, sempre e quando não estejam em desacordo com as normas de contabilidade geralmente aceitas na Colômbia, no Decreto 2649 de 1993.

15) Abandono do método de participação. Quando a filial deixar de ser filial, ou perder a capacidade de dispor a transferência dos lucros, ou decida-se vender o investimento no período seguinte, deverá abandonar-se o método de participação e deverá usar-se o método do custo.

O valor em livros do investimento, a partir da data na qual a principal não continua com o uso do método de participação, considera-se custo. Não obstante os investimentos ou participações que correspondam a lucros que previamente a 
principal tenha reconhecido como no método de participação, deverão registrar-se como menor valor do investimento.

\section{4.- PERU}

No Peru, o Conselho Normativo de Contabilidade, através das Resoluções №s 005-94-EF/93.01, 007-96-EF/93.01 e 011-97-EF/93.01, aprovou a aplicação em nível nacional de 33 Normas Internacionais de Contabilidade (NICs).

No caso dos investimentos em coligadas e controladas é utilizada a NIC nº 28, que apresenta dois métodos de avaliação: o método da equivalência patrimonial e o do custo.

No método de custo, o investimento é avaliado com base no custo histórico, sujeito a reavaliações ou atualizações monetárias; no método da equivalência patrimonial, o investimento inicialmente é contabilizado por seu custo, sendo posteriormente ajustado pelas mutações subseqüentes do patrimônio líquido da investida, proporcionalmente a seu percentual de participação.

Os investimentos permanentes em sociedades sobre as quais se tenha 0 controle, ou se exerça influência significativa em suas decisões, devem ser avaliados conforme o método da equivalência patrimonial. Se o acionista possui, direta ou indiretamente, $20 \%$ (vinte por cento) ou mais das ações com direito a voto de uma companhia, supõe-se que tenha influência significativa. 
Apesar da aceitação das normas do IASC, na prática, devido às leis fiscais, somente é aceito o método do Custo, no qual o custo computável das ações adquiridas por uma empresa vai estar representado pelo custo de aquisição ou o valor de entrada no ativo.

\section{Ajuste por Inflação ${ }^{28}$}

Segundo o Conselho Normativo de Contabilidade, na Resolução № 2, todas as contas que representam investimento em sociedades por ações e participações em outras sociedades devem ser ajustadas pela inflação. Ajusta-se o valor histórico, exceto os valores que estiveram inseridos neles por conceito de:

1) Diferenças de câmbio ocorridas a partir de $1^{\circ}$ de janeiro de 1980 e;

2) Ações ou maiores participações em moeda nominal, recebidas como conseqüência das reavaliações de imóveis, maquinário e equipamento feitas a partir de $1^{0}$ de janeiro de 1980, pelas entidades em cujo capital se participa. De acordo com o Fisco, a exclusão não é aplicável no caso de reavaliações voluntárias com origem na fusão ou divisão de sociedades, de acordo com a Lei № 26283.

\section{Determinação da antiguidade}

a) Como regra geral, a antiguidade dos investimentos existentes na data do ajuste é estabelecida conta por conta desde a data de cada pagamento ou investimento. 
b) Para os dividendos em ações e em maiores participações que se recebam como produto de lucros, que nas sociedades que os geram já estão atualizados em moeda com poder aquisitivo da data de fechamento de cada exercício, a antiguidade é o último dia do exercício anterior ao de sua percepção.

\section{Limite de Atualização}

1. Na aplicação dos limites do ajuste por inflação, deve-se considerar o seguinte:

a) Investimentos em Filiais ou Subsidiárias (controladas), ou seja, naquelas sociedades nas que direta ou indiretamente, em conjunto com outras filiais, se tem mais da metade dos direitos de voto, ou os investimentos de uma filial na sua principal.

Segundo a Norma Internacional de Contabilidade 27, define-se Subsidiária como uma empresa que é controlada por outra empresa, conhecida como a matriz ou principal.

b) Investimentos em filiadas (coligadas), ou seja, naquelas sociedades que junto com a empresa cujas demonstrações financeiras serão ajustadas são filiais de outra; assim como aquelas em que, mediante representação na diretoria, operações significativas com elas, intercâmbio de pessoal de gerência ou dependência de informação técnica se tem a faculdade de participar nas decisões financeiras e de operação, mas sem exercer o controle delas. Em relação a estas

\footnotetext{
${ }^{28}$ IVERA Asociados. Op. citada. Lima, 1999. p. 437 -438.
} 
últimas, deve assumir-se que se tem essa faculdade quando, direta ou indiretamente, em conjunto com outras subsidiárias ou filiadas, possui-se $20 \%$ ou mais dos direitos de voto, exceto quando possa mostrar-se claramente o contrário; deve assumir-se também que existe afiliação ou associação quando, apesar de possuir menos do $20 \%$ dos direitos de voto, a faculdade de associação pode ser claramente demonstrada.

c) Outros investimentos em ações que têm cotação na bolsa de valores.

d) Outros investimentos que não têm cotação na bolsa de valores.

2. Os investimentos em filiais (controladas) ou filiadas (coligadas) têm como limite de ajuste por inflação o menor entre seu valor ajustado e o valor de participação patrimonial na data do ajuste, calculado na base das demonstrações financeiras ajustadas na mesma data pela empresa onde se tem os investimentos.

Contabilmente, indica-se que nos casos que as empresas investidas não possuam a informação oportuna que devem entregar as empresas investidoras, poderão utilizar suas melhores estimativas para preparar sua informação, podendo regularizar as diferenças no fechamento do exercício seguinte.

Para fins tributários, a proporção que corresponda ao investidor nos lucros não distribuídos da empresa em que se tem os investimentos, deve ser subtraída do valor de participação patrimonial, para determinar o limite do ajuste. Isto é conseqüência de que os resultados da empresa em que se tem o investimento já foram tributados. 
3. O limite de ajuste por inflação do conjunto dos investimentos que tem cotação na bolsa de valores é o mais baixo entre o valor ajustado e o valor de cotação na bolsa de valores (líquido das despesas ocorridas na venda) no fechamento do período ou, se não tiver, na cotação anterior a essa data.

A norma tributária vigente a partir do exercício 1996 não obriga a comparar os valores da carteira total, podendo o contribuinte fazer a comparação entre o valor atualizado e o limite para cada um de seus investimentos.

4. Nos investimentos que não tem cotação na bolsa de valores, o limite de ajuste por inflação é o mais baixo entre o valor ajustado e o valor de participação patrimonial.

No quadro seguinte ${ }^{29}$ apresentam-se os diversos tipos de investimentos com seus limites contábeis e tributários. ${ }^{30}$

\footnotetext{
${ }^{29}$ Fonte: "Informativo Caballero Bustamante"

30 "Informativo Caballero Bustamante". Informes Contables. Lima, 1999. p. 32.
} 


\begin{tabular}{|c|c|c|}
\hline Tipo de Inversão & Limite Contábil & Limite Tributário \\
\hline $\begin{array}{l}\text { 1. Em Filial ou } \\
\text { Subsidiária (Nic 27) } \\
\text { (Controlada) }\end{array}$ & $\begin{array}{l}\text { Valor de Participação } \\
\text { Patrimonial } \\
\mathrm{Na} \text { data de atualização, } \\
\text { calculado em base às } \\
\text { Demonstrações Financeiras } \\
\text { ajustadas na data pela } \\
\text { empresa em que se têm os } \\
\text { respectivos investimentos. }\end{array}$ & $\begin{array}{l}\text { Valor de Participação } \\
\text { Patrimonial } \\
\mathrm{Na} \text { data de atualização, } \\
\text { calculado em base ao } \\
\text { Balanço Geral ajustado na } \\
\text { mesma data pela empresa } \\
\text { em que se têm os } \\
\text { respectivos investimentos } \\
\text { sem considerar se estão ou } \\
\text { não cotados em bolsa. }\end{array}$ \\
\hline $\begin{array}{l}\text { 2. Em Afiliada ou Associada } \\
\text { (NIC 28) (Coligada) }\end{array}$ & $\begin{array}{l}\text { Valor de Participação } \\
\text { Patrimonial } \\
\mathrm{Na} \text { data de atualização, } \\
\text { calculado em base às } \\
\text { Demonstrações Financeiras } \\
\text { ajustadas na data pela } \\
\text { empresa em que se têm os } \\
\text { respectivos investimentos. }\end{array}$ & $\begin{array}{l}\text { Valor de Participação } \\
\text { Patrimonial } \\
\mathrm{Na} \text { data de atualização, } \\
\text { calculado em base ao } \\
\text { Balanço Geral ajustado na } \\
\text { mesma data pela empresa } \\
\text { em que se têm os } \\
\text { respectivos investimentos } \\
\text { sem considerar se estão ou } \\
\text { não cotados em bolsa. }\end{array}$ \\
\hline $\begin{array}{l}\text { 3. Outros investimentos com } \\
\text { cotação na Bolsa de Valores }\end{array}$ & $\begin{array}{l}\text { Valor de Cotação na Bolsa } \\
\text { de Valores } \\
\text { (Reduzido das despesas } \\
\text { realizadas na venda) } \\
\text { No fechamento do período } \\
\text { ou, se não houver, a cotação } \\
\text { anterior à data para o } \\
\text { conjunto da carteira de } \\
\text { investimentos. }\end{array}$ & $\begin{array}{l}\text { Valor de Cotação na Bolsa } \\
\text { de Valores } \\
\text { (Reduzido das despesas } \\
\text { realizadas na venda) } \\
\text { No fechamento do período } \\
\text { ou, se não houver, a cotação } \\
\text { anterior à data. }\end{array}$ \\
\hline $\begin{array}{l}\text { 4. Outros investimentos não } \\
\text { cotados em bolsa }\end{array}$ & $\begin{array}{c}\text { Valor de Participação } \\
\text { Patrimonial }\end{array}$ & $\begin{array}{c}\text { Valor de Participação } \\
\text { Patrimonial }\end{array}$ \\
\hline $\begin{array}{l}\text { 5. Outros investimentos } \\
\text { ouro, prata, obras de arte }\end{array}$ & $\begin{array}{c}\text { Valor de Mercado ou valor } \\
\text { de Taxação }\end{array}$ & Não tem \\
\hline
\end{tabular}




\section{Considerações}

Nos casos exclusivamente financeiros, quando o valor nominal das ações for maior que o valor de custo menos a provisão para flutuação de valores, se houver, poderá tomar-se este último valor como limite.

\section{5.- VENEZUELA}

31“A DPC-7 estabelece dois critérios para a mensuração e apresentação nas demonstrações financeiras, dos investimentos em longo prazo em ações com direito a voto:

- Influência significativa

- Controle

A Influência significativa é um aspecto de juízo objetivo e subjetivo, devido a uma participação acionária significativa não necessariamente implicar em uma influência significativa nas operações de uma entidade, pelo que o aspecto quantitativo pode ser substituído por um argumento de juízo".

A DPC-7 estabelece em seu parágrafo 4 o seguinte:

32،4. A forma em que estes termos relacionam-se com a mensuração e informação dos investimentos a longo prazo em ações de capital é como segue: 


\section{Nível de Propriedade}

1. Controle (mais do $50 \%$ das ações)

2. Proprietários e administração comuns

(sem relação de propriedade entre companhias)

3. influência significativa mas não controle (entre o $20 \%$ e $50 \%$ das ações)

4. Sem influência significativa nem controle (menos do $20 \%$ das ações)
Método de Mensuração e

Apresentação

Consolidação

Combinação

\section{Patrimonial}

Custo"

"Quando são preparadas demonstrações financeiras consolidadas, combinadas, ou se aplica o método de participação patrimonial, a situação legal das entidades ou companhias individuais na dita demonstração não é um assunto importante. Nestes casos tem maior importância o aspecto financeiro envolvido que dá origem à consolidação, combinação ou aplicação do método de participação patrimonial.

O valor de mercado das ações de uma companhia em termos econômicos deve ser determinado pelo valor presente das receitas e lucros futuros. Pode existir uma sobre-avaliação baseada no valor de seus estoques, do custo de reposição de seus ativos (itens não monetários) ou das vantagens competitivas que possa ter a companhia, assim, determina-se o valor a ser pago pelos

\footnotetext{
${ }^{31}$ Carpio, Fernando Catacora. Op. citada. Caracas, 1999.

${ }^{32}$ DPC-7 apud Carpio, Fernando Catacora. Op. citada. Caracas, 1999.
} 
investidores, que no geral resulta maior que o ativo líquido, ou valor contábil da companhia.

No caso de diferenças pagas que não possam ser atribuídas a uma conta específica do ativo, é o que se denomina "ágio" ou "excesso de custo sobre o valor líquido em livros de ações de filiais". Este excesso de custo deve ser calculado considerando-se a participação que tem a companhia que está investindo no momento ou na data da aquisição.

Poderia ocorrer que o valor pago ou custo das ações da companhia filial resulte menor que o valor líquido em livros da participação da companhia matriz na filial e que este excesso de valor líquido dos ativos se apresenta no patrimônio em uma conta e não é amortizável”. ${ }^{33}$

\footnotetext{
${ }^{33}$ Carpio, Fernando Catacora. Op. citada. Caracas, 1999.
} 


\section{4.- ATI VO I MOBI LI ZADO}

\section{1.- ARGENTINA:}

a) Federação Argentina de Conselhos Profissionais de Ciências Econômicas - FACPCE.

34 "A Resolução Técnica n 10 da FACPCE dita as normas sobre a avaliação do imobilizado no item B - 3.13. Há duas opções, estabelecendo uma ordem marcada pelas práticas vigentes, com o objetivo de ir gradualmente direcionando-se para a utilização do critério de valores correntes. Caso esse critério traga dificuldades práticas pela não disponibilidade de tais valores, recomenda-se o uso do critério do custo original corrigido por índice específico, indicado na letra b item 2.

a. Custo original expresso em moeda constante - nesse caso, o custo original será corrigido de acordo com o "índice de preços por atacado - nível geral"

b. Valores correntes - este critério pode ser expresso de três formas:

1. Custo de reposição - para o caso em que se encontre disponível o custo de reposição direto, será a alternativa mais recomendada. Deverá tratar-se de bens com um mercado efetivo; por exemplo, frotas de veículos

\footnotetext{
${ }^{34}$ http://www.facpce.com.ar/
} 
de transporte para vendedores ou empregados de uma empresa, terrenos, etc. Quando só existirem no mercado bens novos de idênticas características às do bem a avaliar, considerar-se-á o custo de reposição do novo menos a depreciação correspondente.

2. Custo original corrigido por índice específico - neste caso, o custo original acumulado será expresso de acordo com a evolução de um ou mais índices específicos de preços do tipo de bens de que se trata. Para que sejam válidos estes índices deverão ser selecionados entre os publicados pelo "Indec Instituto Nacional de Estatísticas e Censos" -, ou calculados sobre a base deles mediante um processo que seja suscetível de verificação por parte de terceiros. Porém, será necessário que o índice utilizado seja o mais apropriado para reconhecer a evolução de preços de bens pertencentes a um tipo igual ou similar ao dos bens em consideração.

3. Avaliações técnicas (reavaliações) - as avaliações técnicas deverão ser preparadas por profissionais independentes ou equipes interdisciplinares de profissionais independentes, em ambos os casos com a correspondente habilitação profissional e de reconhecida idoneidade nesse tipo de avaliação. Em todos os casos, será requerida a participação de um contador público. Deverá ser analisado se os bens podem ser avaliados individualmente ou se, apenas considerando seu conjunto, pode-se chegar a valores adequados. As avaliações técnicas se basearão, como ponto de partida, no valor de substituição da capacidade de serviços dos bens, entendendo-se como tal o montante necessário para adquirir ou produzir aqueles que, ao fim da atividade da 
sociedade, tenham significação econômica equivalente e resultem substitutos lógicos dos existentes. Pode-se tomar a última avaliação técnica como base para sua expressão posterior, usando índices específicos para o tipo considerado de bens. Esse procedimento só poderá ser aplicado caso não se tenham produzido mudanças que gerem dúvidas sobre a validade dos resultados obtidos. No caso em que não existam índices específicos publicados pelo Indec que possam ser aplicados, poderá ser utilizado o "índice de preços por atacado - nível geral”, devendo-se ter as mesmas precauções a respeito da validade dos resultados obtidos. As contrapartidas dos acréscimos oriundos das reavaliações são contabilizadas diretamente em contas de resultado.

Em qualquer dos critérios descritos e dependendo da natureza dos bens, serão deduzidas as depreciações acumuladas até a data de encerramento do exercício, computadas sobre o valor contábil de tais bens. Para o cálculo das depreciações, deve ser considerada, fundamentalmente, a capacidade de produção do bem, vinculando sua existência ao tipo de exploração a que corresponda. Deverão ser identificados e expostos seus efeitos, em todos os casos em que ocorra uma das circunstâncias seguintes: (a) mudança de base de avaliação ou de nova expressão; (b) extensão ou redução de vida útil atribuída; (c) alteração de métodos ou critérios de amortização".

\section{A RT nำ 16, Marco Conceitual das Normas Contábeis Profissionais ${ }^{35}$}

(vai entrar em vigência em 2001)

\footnotetext{
${ }^{35}$ http://www.facpce.com.ar/
} 
Conceitos importantes da RT no 16 :

"Ativos

Uma entidade tem um ativo quando, devido a um fato já ocorrido, controla os benefícios econômicos que produzem um bem (material ou imaterial, com valor de troca ou de uso para a entidade.)

Um bem tem um valor de uso quando a entidade pode utilizá-lo em alguma atividade produtora de receitas".

A RT no 17, Normas contábeis Profissionais: desenvolvimento de aspectos de aplicação geral. (vai entrar em vigência em 2001).

36“"Em geral, a mensuração original dos bens incorporados e dos serviços adquiridos será na base de seu custo.

O custo de um bem é o necessário para colocá-lo em condições de ser vendido ou utilizado, o que corresponda em função de seu destino.

Bens ou serviços adquiridos: é a soma do preço que deve pagar-se por sua aquisição a vista e da parcela pelas despesas de compra e do controle de qualidade.

O custo de um bem produzido é a soma de:

- $\quad$ as despesas de materiais e insumos necessários para sua produção;

\footnotetext{
${ }^{36} \mathrm{http}: / / \mathrm{www}$. facpce.com.ar
} 
- seus custos de conversão (mão de obra, serviços e outras despesas), tanto variáveis como fixos.

- as despesas financeiras que possam atribuir-se.

O custo dos bens produzidos não deve incluir:

- improdutividades físicas ou ineficiências no uso dos fatores em geral;

- a ociosidade produzida por falta de aproveitamento dos fatores fixos originada pela não utilização da capacidade de planta no seu nível normal.

Determinação dos valores correntes dos ativos destinados à venda ou a ser consumidos no processo de obtenção de bens ou serviços destinados à venda.

Nos casos de ativos cuja venda não requeira esforços significativos, se procederá assim:

- quando os bens estejam em condições de ser entregues, será utilizado um valor corrente de saída;

- no caso contrário, se utilizará o valor líquido de realização proporcionado segundo o grau de avanço da produção ou construção do bem e do correspondente processo de geração de resultados.

Para os demais ativos em geral, se utilizará o valor corrente de entrada ou custo de reposição.

Nenhum ativo poderá apresentar-se nas demonstrações financeiras por um montante superior a seu valor recuperável, que é o maior montante entre: 
- seu valor líquido de realização;

- seu valor de uso, definido como o valor atual esperado dos fluxos líquidos de fundos que deveriam surgir do uso dos bens e de sua disposição no final de sua vida útil (ou de sua venda antecipada).

\section{Avaliação dos Bens do Imobilizado}

Sua avaliação será ao custo original menos a depreciação acumulada.

As despesas posteriores ao reconhecimento inicial de um ativo serão incorporadas quando:

- o desembolso constitui uma melhora e seja provável que o ativo gere receitas netas de fundos em excesso dos originalmente previstos;

- as despesas sejam originadas por tarifas de manutenção ou recondicionamento maiores que somente permitam recuperar a capacidade de serviço do ativo para conseguir seu uso contínuo.

As demais despesas posteriores à incorporação do bem serão consideradas reparações correspondentes ao período em que sejam realizadas.

\section{As Depreciações:}

Para o cálculo das depreciações, vai considerar-se para cada bem:

- Sua avaliação contábil;

- Sua natureza; 
- Sua data de colocação em atividade, que é o momento a partir do qual devem calcular-se as depreciações;

- Se há evidências de perda do valor anteriores a seu funcionamento, deve reconhecer-se;

- Sua capacidade de serviço;

- A possibilidade de que somente umas partes sofram perda;

- O valor líquido de realização que se espera terá o bem quando se esgote sua capacidade de serviço;

- A capacidade de serviço já utilizado por desgaste normal;

- A deterioração que o bem pode ter por outras razões.

Quando um ativo seja incorporado por arrendamento financeiro e a intenção de sua propriedade não seja segura deve ser totalmente depreciado ao longo do prazo de seu contrato, ou de sua capacidade de serviço, o menor".

\section{b) Comissão Nacional de Valores - CNV}

37،A CNV não admite a contabilização de reavaliações do ativo imobilizado. $\mathrm{Na}$ verdade, quando a avaliação do imobilizado é feita a valores correntes, tornam-se dispensáveis as reavaliações”.

\section{c) Fisco}

38“O Fisco não trata especificamente da avaliação dos bens, donde se conclui que há aceitação dos critérios contábeis praticados. A respeito da

\footnotetext{
${ }^{37}$ Da Rosa, Paulo. Op. citada. São Paulo, 1999. p. 124.

${ }^{38}$ Da Rosa, Paulo. Op. citada. São Paulo, 1999. p. 124.
} 
depreciação, utiliza-se o conceito de vida útil; suas taxas, em alguns itens, são diferentes das adotadas no Brasil"

\section{2.- BRASIL}

a) Conselho Federal de Contabilidade - $\mathrm{CFC}^{39}$

De acordo com a NBC T 4 - Da Avaliação Patrimonial estabelece-se:

"4.2.7.1 - Os componentes do ativo imobilizado são avaliados ao custo de aquisição ou construção, atualizado monetariamente, deduzido das respectivas depreciações, amortizações e exaustões acumuladas, calculadas com base na estimativa de sua utilidade econômica.

4.2.7.2 - Os bens e direitos recebidos por doação são registrados pelo valor nominal ou de mercado, o que for mais claramente identificado.

4.2.73 - O fundo de comércio e outros valores intangíveis adquiridos são avaliados pelo valor transacionado, atualizado monetariamente, deduzido das respectivas amortizações calculadas com base na estimativa de sua utilidade econômica."

\section{b) Lei das Sociedades por Ações}

No art. 183 no balanço, os elementos do ativo serão avaliados segundo os seguintes critérios: ${ }^{40}$

\footnotetext{
${ }^{39}$ CFC. Princípios Fundamentais de Contabilidade e Normas brasileiras de Contabilidade. São Paulo, 1995. p. 143.
} 
"V - os direitos classificados no imobilizado, pelo custo de aquisição, deduzido do saldo da respectiva conta de depreciação, amortização ou exaustão."

“2 - A diminuição de valor dos elementos do ativo imobilizado será registrada periodicamente nas contas de:

a) depreciação, quando corresponder à perda do valor dos direitos que têm por objeto bens físicos sujeitos a desgastes ou perda de utilidade por uso, ação da natureza ou obsolescência;

b) amortização, quando corresponder à perda do valor do capital aplicado na aquisição de direitos da propriedade industrial ou comercial e quaisquer outros com existência ou exercício de duração limitada, ou cujo objeto sejam bens de utilização por prazo legal ou contratualmente limitado;

c) exaustão, quando corresponder à perda do valor, decorrente da sua exploração, de direitos cujo objeto sejam recursos minerais ou florestais, ou bens aplicados nessa exploração."

No art. 182 estabelece a reavaliação dos ativos:

“§ $3^{0}$ - Serão classificadas como reservas de reavaliação as contrapartidas de aumentos de valor atribuídos a elementos do ativo em virtude de novas avaliações com base em laudo nos termos do Art. 8ํㅜ, aprovado pela assembléia geral."

\footnotetext{
${ }^{40}$ Lei № 6.404 de 15 de dezembro de 1976 alterada pela lei $n^{0} 9.457$ de 5 de maio de 1997. Brasília, 1997.p. $269-270$, e 213 .
} 
As disposições deste artigo correspondem à avaliação de bens a serem incorporados ao patrimônio da sociedade, via integralização de capital, aplicandose também às reavaliações de bens.do ativo.

"Art. 8- A avaliação dos bens será feita por 3 (três) peritos ou por empresa especializada, nomeados em assembléia geral dos subscritores, convocada pela imprensa e presidida por um dos fundadores, instalando-se em primeira convocação com a presença de subscritores que representem metade, pelo menos, do capital social, e em segunda convocação com qualquer número.”

\section{c) IBRACON}

O novo Pronunciamento NPC 7 - Ativo Imobilizado substitui 0 Pronunciamento VII - Imobilizado e entra em vigor a partir de $1^{0}$ de janeiro de 2001.

${ }^{41}$ "Este Pronunciamento requer que um item de ativo imobilizado seja reconhecido como tal, quando ele satisfizer a definição e os critérios de reconhecimento para os ativos, constantes dos Princípios Fundamentais de Contabilidade.

Ativo imobilizado objeto deste Pronunciamento compreende os ativos tangíveis que:

\footnotetext{
${ }^{41}$ IBRACON. NPC 7 Ativo Imobilizado. São Paulo. 2001.
} 
a. são mantidos por uma empresa para uso na produção ou fornecimento de mercadorias ou serviços, para locação a terceiros, ou para finalidades administrativas; e

b. conforme a expectativa, deverão ser usados por mais de um período.

Um item do ativo imobilizado deve ser reconhecido como um ativo, quando:

a. for provável que a empresa venha a auferir futuros benefícios econômicos em decorrência da sua utilização, e

b. o custo do ativo puder ser medido de forma confiável.

O valor depreciável de um bem do ativo imobilizado deve ser apropriado numa base sistemática durante a sua vida útil econômica. O método de depreciação usado deve refletir o padrão em que os benefícios econômicos do ativo são consumidos pela empresa. A parcela de depreciação referente a cada período deve ser contabilizada como despesa ou custo, a não ser que seja incluída no valor contábil de outro ativo".

No seu Pronunciamento XXIV, o Ibracon dita as normas da reavaliação de $\operatorname{ativos}^{42}$

1. "A reavaliação significa a adoção do valor de mercado para os bens reavaliados, abandonando-se o princípio de custo corrigido. Conceitualmente, objetiva que o balanço reflita valores mais próximos da sua efetiva realidade

\footnotetext{
${ }^{42}$ IBRACON. Princípios contábeis. São Paulo, 1994. p.87-92.
} 
econômica em termos de ativos e, conseqüentemente, do patrimônio líquido da empresa.

2. Permite, ainda, que os bens do imobilizado reavaliados sejam apropriados, através da depreciação, aos custos ou despesas por tais valores atualizados, apurando resultados operacionais mais consentâneos com o conceito de reposição dos ativos.

3. A atualização do patrimônio líquido das empresas, em função da reavaliação, reflete de maneira mais adequada a realidade de seus ativos, gerando uma relação mais correta entre capital próprio e de terceiros".

São hipóteses possíveis de reavaliação segundo o §12 do Pronunciamento as seguintes:

"a. reavaliação voluntária de ativos próprios;

b. reavaliação de ativos por controlada e coligada;

c. reavaliação na subscrição de capital em outra empresa com conferência de bens;

d. reavaliação em fusão, incorporação ou cisão de empresas".

As informações sobre reavaliações a serem divulgadas em Notas Explicativas estão no §67:

"a. histórico e data da reavaliação - somente no exercício de reavaliação;

b. sumário, por conta, dos valores de avaliação, respectivos valores contábeis e o valor da reserva constituída - somente no exercício da reavaliação. 
c. efeito no resultado do exercício, oriundo das depreciações, amortizações ou exaustões sobre a reavaliação, e eventuais baixas posteriores a seu registro;

d. tratamento quanto a dividendos e participações e menção à responsabilidade da empresa relativa ao imposto de renda futuramente exigível".

\section{d) Comissão de Valores Mobiliários - $\mathrm{CVM}^{43}$}

“De acordo com o Ofício Circular CVM/PTE nº 578/85, item 5, e o Ofício Circular CVM/PTE no 309/86 item 15, as despesas financeiras não podem ser incluídas no valor do imobilizado.

A Instrução CVM nº 191, de 15-7-92, em seu art. 7º, determina que os itens não monetários, entre os quais se enquadra o Ativo Permanente, devem ser registrados por seu valor presente, na data de sua aquisição ou formação.

Segundo o Parecer de Orientação $n^{0}$ 24, de 15-1-92, item 14, a CVM trata da Consolidação das Notas Explicativas; no tópico Avaliação, estabelece:

"Deverão ser divulgados os principais critérios de avaliação dos elementos patrimoniais, especialmente estoques, dos cálculos de depreciação, amortização e exaustão, de constituição de provisões para encargos ou riscos e dos ajustes para atender perdas prováveis na realização de elementos do ativo."

Na Deliberação CVM no 27, de 5-2-1986, a CVM aprovou o Pronunciamento "XXIV - Reavaliação de Ativos" do Ibracon, tornando-o aplicação obrigatória por parte das companhias abertas. No Parecer de Orientação $n^{0} 24$, no tópico 
Reavaliação, a CVM reeditou os itens sugeridos pelo Ibracon referente às informações que devem constar nas notas explicativas, e acrescentou os seguintes:

- utilização da reserva para aumento de capital ou compensação de prejuízos;

- reavaliações parciais, ressaltando os itens reavaliados; e

- reavaliações em controladas, evidenciando as companhias que fizeram reavaliações e as que não o fizeram.

Embora a Lei das Sociedades por Ações mencione que a Reavaliação pode ser feita para os elementos do Ativo, a CVM, em sua Deliberação nº 183, de 19-61995, restringe a reavaliação basicamente aos bens tangíveis do ativo imobilizado, e isso desde que não esteja prevista sua descontinuidade".

\section{e) $\mathrm{Fisco}^{44}$}

"De acordo com o art. 11, item II, da Lei n- 7.799, de 10-7-89 "os bens do imobilizado devem ser agrupados em contas distintas segundo sua natureza e as taxas anuais de depreciação ou amortização a eles aplicáveis; os imóveis, os recursos minerais e florestais e as propriedades imateriais deverão ser registrados em sub-contas separadas."

\footnotetext{
${ }^{43}$ Da Rosa, Paulo. Op. citada. São Paulo, 1999. p.120.

${ }^{44}$ Da Rosa, Paulo. Op. citada. São Paulo, 1999. p. 121 -122.
} 
A base para avaliação de bens componentes do ativo imobilizado é seu custo de aquisição (valor original). A escrituração deve ser mantida conforme determina 0 art. 12 da Lei $n^{0}$ 7.799/89:

"Art. 12. O contribuinte deve manter registros que permitam identificar os bens do imobilizado e determinar o ano da sua aquisição, o valor original e os posteriores acréscimos ao custo, reavaliações e baixas parciais a eles referentes."

De acordo com o art. 326 do Regulamento do Imposto de Renda/80: "A contrapartida do aumento de valor de bens do ativo permanente, em virtude de nova avaliação baseada em laudo nos termos do art. $8^{0}$ da Lei $n^{0} 6.404$, de 15 de dezembro de 1976, não será computada no lucro real enquanto mantida em conta de reserva de reavaliação (Decreto-lei $n^{0}$ 1.598/77, art. 35 e Decreto-lei $n^{0}$ 1.730/79, art. 1ํ, $\mathrm{VI}) . "$

\section{3.- COLÔMBIA}

45 “De acordo com o art. 64 do D.R. 2649/93: Os imóveis, maquinaria e equipamento, representam os ativos tangíveis adquiridos, construídos, ou em processo de construção, para ser utilizados em forma permanente na produção ou no abastecimento de outros bens e serviços, para ser alugados, ou para ser utilizados na administração da entidade econômica, não são destinados à venda e sua vida útil excede um ano.

\footnotetext{
${ }^{45}$ Régimen Contable Colombiano. Bogotá, 1996. p.287 -311.
} 
O valor histórico desses ativos inclui todas as despesas necessárias até serem colocados em condições de ser utilizados, como despesas de engenharia, supervisão, impostos, juros, correção monetária da UPAC - "Unidade de poder aquisitivo constante" e ajustes por diferença de câmbio.

O valor histórico dos imóveis, maquinaria e equipamento, recebidos em troca, permuta, doação, ou como aporte dos proprietários, se determina pelo valor conveniado pelas partes, devidamente aprovado pelas autoridades ou, quando não se determine o preço, através da avaliação.

O valor histórico deve ser incrementado com as adições, melhoras e reparações, para aumentar a quantidade e qualidade da produção ou a vida útil do ativo.

Vida útil é o lapso durante o qual o imóvel, a maquinaria ou o equipamento contribuirão à geração de receitas. Para sua determinação é necessário considerar as especificações de fábrica, o deterioro pelo uso, a ação de fatores naturais, a obsolescência por avanços tecnológicos e as mudanças dos bens e serviços a cuja produção ou abastecimento o imobilizado contribui.

A contribuição destes ativos à geração da receita deve ser reconhecida nos resultados do exercício mediante a depreciação de seu valor histórico ajustado. Quando seja significativo esse montante deve-se subtrair o valor residual tecnicamente determinado. As depreciações dos imóveis devem ser calculadas excluindo o custo do terreno respectivo. 
A depreciação se determina mediante métodos de reconhecido valor técnico, como a linha reta, a soma dos dígitos dos anos, as unidades de produção ou horas de trabalho. Deve ser utilizado o método mais adequado para a empresa.

No final do período, o valor líquido destes ativos ajustados pela inflação, deve ser ajustado a seu valor de realização ou a seu valor atual ou a seu valor presente, o mais apropriado nas circunstâncias, registrando as provisões ou valorizações necessárias. Podem ser excetuados desta disposição aqueles ativos cujo valor ajustado seja inferior a vinte salários mínimos mensais.

O valor de realização, atual ou presente destes ativos, deve ser determinado no final do período onde foram adquiridos ou formados e no mínimo cada três anos, mediante avaliações praticadas por pessoas naturais, vinculadas ou não à entidade econômica, ou por pessoas jurídicas, de comprovada idoneidade profissional, solvência moral, experiência e independência. Quando não existam impedimentos, entre as avaliações os ativos se ajustam no final do período utilizando indicadores específicos de preços segundo publicações oficiais ou pelo PAAG - "Porcentagem do ajuste do ano tributável" correspondente.

A avaliação deve ser preparada de maneira neutral e por escrito, de acordo com as seguintes regras:

1) Apresentará seu montante discriminado por unidades ou por grupos homogêneos. 
2) Os bens de uma mesma classe e características serão tratados de forma coerente.

3) Deverão ser considerados os critérios utilizados pela entidade econômica para registrar adições, melhoras e reparações.

4) Deve indicar a vida útil remanescente que o ativo teria em condições normais de operação.

5) Diferenciará os bens móveis tratados como imóveis, mostrando seu valor por separado".

\section{4.- PERU}

De acordo com o Plano Contábil Geral Revisado, 46 "a conta 33 Imóveis, maquinaria e equipamento representa os bens utilizados na produção ou outros serviços da empresa, e tem as seguintes características:

- Uma vida útil relativamente grande;

- não estão disponíveis para a venda;

- podem ser depreciados, excetuando os terrenos.

Os bens do imobilizado devem ser registrados ao custo de aquisição, ou preço de compra.

\footnotetext{
${ }^{46}$ Rueda, Gregorio. Op. citada. Lima, 1999. p. $74-78$.
} 
O preço de compra inclui o total de despesas necessárias para adquirir e colocar estes bens em condições de ser usados, tais como: fretes, seguros, despesas de envios, direitos aduaneiros, instalação, montagem, honorários por serviços técnicos, comissões normais do agente e outros similares.

Isto é também aplicável, até onde corresponda, aos imóveis, maquinaria e equipamento, tanto construídos pela mesma empresa, como outorgados pelos sócios, recebidos por doação ou ingressados no patrimônio por outra causa.

Os juros realizados durante o período de construção e instalação do ativo devem ser capitalizados até o momento que o ativo possa ser utilizado no serviço, e desde esse momento os juros deverão afetar os resultados.

As despesas que aumentam a capacidade de produção ou prolongam a vida útil do bem tem a condição de melhoras ou reparações; e devem aumentar o valor do bem correspondente.

As maquinarias e equipamentos de reserva que não estão em serviço devem ser registrados na conta 337 Unidades de reserva; as unidades por receber e outras construções em processo, assim como as maquinarias e equipamentos em montagem devem ser registrados até sua entrada ou terminação nas contas 338 - Unidades por receber e 339 - Trabalhos em curso, respectivamente. Devido a sua condição especial não devem ser depreciados.

As construções, assim como a maquinaria e equipamento têm com maior ou menor intensidade, perdas de valor originadas pelo desgaste devido ao uso, 
obsolescência ou outras causas. Essas perdas devem afetar o resultado do exercício, ou devem ser absorvidas nos anos de vida útil.

A depreciação será calculada sobre o custo de aquisição, o preço de compra mais as melhoras incorporadas, assim como as reavaliações efetuadas por disposições vigentes. É necessário ter em consideração para a escolha do método e as taxas de depreciação, a natureza dos bens e sua vida útil estimada.

As contas de avaliação serão utilizadas quando forem necessárias. As contas de avaliação devem ser mostradas como redução do ativo específico, de preferência em notas às demonstrações financeiras.

Não devem ser registrados aqui os juros realizados do saldo do preço que ainda não foi pago das unidades adquiridas e colocadas em funcionamento, ou o saldo dos empréstimos para a compra dessas unidades que serão debitadas na conta Despesas Financeiras".

\section{Ajuste por Inflação ${ }^{47}$}

"Segundo a Resolução N ${ }^{0} 2$ do Conselho Normativo de Contabilidade, todas as contas do Imobilizado, incluindo plantações, Gado reprodutor e de carga, devem ser ajustados pela inflação. Ajusta-se o valor em livros de cada um dos bens e, separadamente, sua depreciação acumulada.

Não se ajusta:

a) As diferenças de câmbio ocorridas a partir de $1^{0}$ de janeiro de 1980; e 
b) As reavaliações feitas a partir de $1^{0}$ de janeiro de 1980. São componentes do valor ajustado as diferenças de câmbio ocorridas até o 31 de dezembro de 1979, assim como as reavaliações feitas até essa data, devido a que é a data de maior antiguidade para a aplicação destas normas.

\section{Procedimentos de atualização}

1. Como regra geral, a antiguidade dos bens existentes na data de cada atualização é a de cada despesa.

2. As aquisições feitas em 1979 e que não foram reavaliadas no fim desse ano são ajustadas aplicando o fator correspondente ao mês em que se fez cada despesa nesse ano.

3. A depreciação acumulada será ajustada de acordo com a antiguidade do ativo que Ihe deu origem sem modificar o tempo de vida útil do bem que será ajustado e o método de depreciação utilizado.

No ajuste da depreciação acumulada poderá se usar um dos seguintes procedimentos:

a) Recálculo da depreciação aplicando a taxa respectiva ao custo ajustado, pelo tempo em que o bem foi depreciado, para obter a depreciação acumulada ajustada.

\footnotetext{
${ }^{47}$ IVERA Associados. Op. citada. Lima, 1999. p. 438 - 440.
} 
A depreciação ajustada do ano será determinada pela depreciação acumulada ajustada na data das demonstrações financeiras, subtraindo a depreciação acumulada ajustada do exercício anterior.

b) Decomposição da depreciação acumulada histórica. A depreciação acumulada histórica será ajustada pelo fator de ajuste do ativo que the deu origem.

Ambos procedimentos podem ser aplicados à atualização de cada bem ou grupo de bens adquiridos em um período.

A depreciação ajustada do período será distribuída sobre a mesma base ou porcentagens estabelecidos para a depreciação histórica.

4. Os imóveis, maquinarias e equipamentos totalmente depreciados que tenham valor de utilidade econômica também poderão ser ajustados.

\section{Limite de atualização}

1. O valor ajustado dos imóveis, maquinaria e equipamentos não deve exceder ao valor que a empresa pode recuperar do uso futuro deste ativo, valor de utilização econômica ou feita por peritos independentes. No caso de terrenos, o limite de ajuste será fixado de acordo com a Tabela vigente na data do ajuste, que publique o "Ministério da Fazenda", de acordo as normas estabelecidas pelo Regulamento Geral de Taxações do Peru, ou de uma Taxação independente, a menor. 
2. Quando, por opção da empresa, se limite o valor ajustado ao valor de utilização econômica ou quando for feita por peritos independentes, por razões tributárias, deve-se apoiar estes últimos com um estudo feito por profissional capacitado, inscrito no Conselho e independente da empresa.

3. O ajuste dos equipamentos de computação e de escritório pode limitar-se a seu valor de reposição quando este seja o valor ajustado.

\section{Comentário}

Quando o montante ajustado correspondente ao primeiro ajuste seja menor ao valor registrado nos livros, se poderá tomar como ajuste o saldo pelos livros".

\section{5.- VENEZUELA ${ }^{48}$}

"O montante atualizado de um item não monetário é reduzido quando excede o montante recuperável de uso futuro (incluindo a venda ou outra disposição). Nestes casos, são reduzidos os montantes atualizados de Propriedades, Plantas e Equipamentos.

O montante recuperável é considerado o Valor de Realização líquido ou o Valor de uso futuro.

O seguinte esquema mostra adequadamente a avaliação dos ativos fixos corrigidos que tem como limite o valor recuperável. 


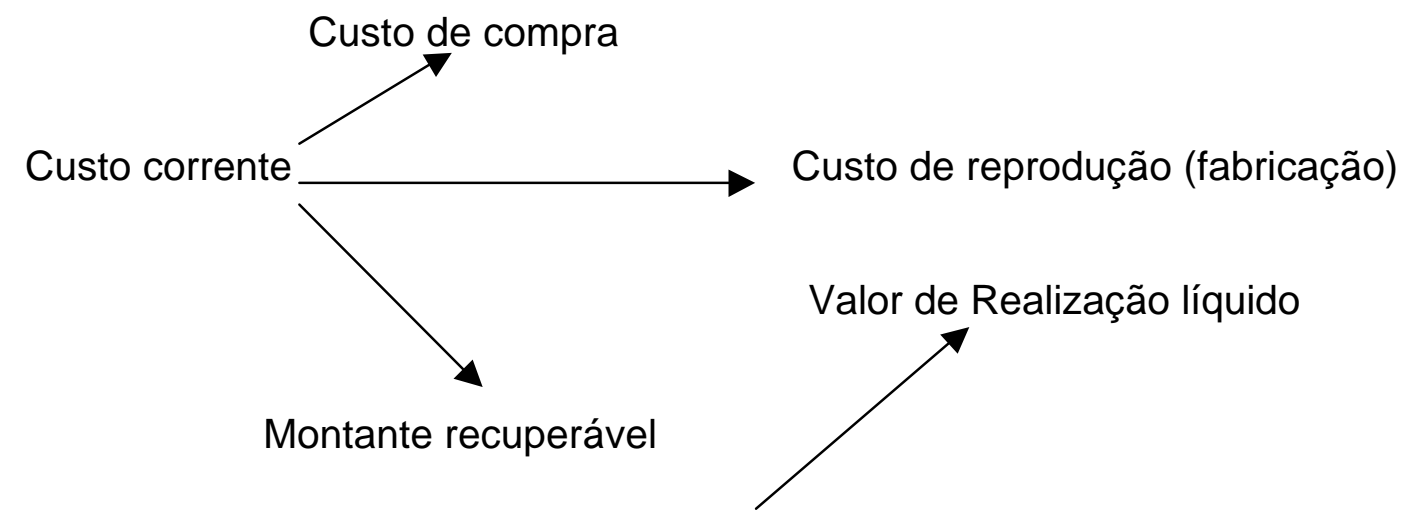

( Quando este é menor que os

dois anteriores)

Valor de uso

No primeiro boletim de Atualização da DPC-10 fala-se:

A reavaliação e suas atualizações sempre que seja feito de acordo com o Método Misto é um princípio aceito na Venezuela.

NGP + Reavaliação = Método Misto.

A Reavaliação dos itens não monetários dentro do Método Misto pode-se fazer dentro de uma das seguintes alternativas:

a) Todo o Ativo Fixo

b) Todo o Ativo Fixo e os estoques

Deve-se informar a opção eleita. A avaliação não deve se fazer em forma global. Todos os bens de classe e características comuns devem tratar-se em

\footnotetext{
${ }^{48}$ CARPIO, Fernando Catacora. Op. citada. Caracas, 1999.
} 
forma similar, no sentido de não incluir ou excluir determinados ativos com o objetivo de conseguir resultados predeterminados.

No segundo boletim de atualização da DPC 10, estabelece-se o seguinte:

Para efeitos das demonstrações financeiras atualizadas deve eliminar-se, antes da atualização das cifras históricas, qualquer montante previamente reconhecido como parte do custo dos ativos provenientes de desvalorizações ou flutuações no valor da moeda, incluindo qualquer montante registrado em gastos diferidos por esse motivo. Este informe exige a saída de montantes capitalizados como diferenças cambiais.

No caso de ativos alienados ou retirados, que sejam objeto da avaliação:

O lucro ou a perda proveniente da alienação ou retirada de um ativo fixo reavaliado é determinado de acordo com o valor líquido atualizado e não do custo histórico.

Isto é aplicado no método NGP ou no método Misto.

No caso do Resultado por posse:

Os resultados por posse conhecidos como superávit por reavaliação devem determinar-se de acordo com o parágrafo 18 da DPC-10.

Nas demonstrações financeiras consolidadas ou combinadas, onde a companhia matriz e suas filiais reavaliaram seus ativos fixos, os resultados por posse consolidados apresentam-se dessa forma". 
O parágrafo 31 diz o seguinte:

“31. As despesas de depreciação do exercício são atualizadas no método NGP colocando nas alíquotas históricas registradas nos livros legais, ajustadas pelos conceitos estabelecidos na DPC-10 (avaliações, diferenças de câmbio capitalizadas, juros de financiamento, etc.) a data de aquisição ou construção do ativo que os gera. Não deve haver discrepância entre a alíquota da depreciação histórica, seu fator de atualização e a cifra atualizada. Não é adequado efetuar atualizações por distribuição proporcional em base à atualização global dos ativos fixos ou sua depreciação acumulada nem qualquer outra média global que possa introduzir fatores de distorção nos resultados, de difícil verificação.

Como conseqüência deste parágrafo, deve-se eliminar qualquer efeito por:

- Avaliações

- Diferenças de câmbio capitalizadas

- Juros, despesas

E depois atualizar a despesa por depreciação correspondente considerando a data de aquisição ou construção do ativo com o qual está relacionado.

No parágrafo 45 , define que os ativos fixos em cifras históricas somente podem apresentar reavaliações até 8 de novembro de 1992.

Depois dessa data, o ativo fixo somente pode ser reavaliado no método integral Misto. O método Misto, no caso dos ativos fixos, consiste em unir o Método do Nível Geral de Preços com as Reavaliações 
- NGP + Avaliações

Portanto, apresentar o seguinte esquema é errado:

Cifras históricas + Avaliações

Isto significa que somente podem ser reavaliados os imobilizados corrigidos pela inflação através do Método do Nível Geral de Preços.

\section{Capitalização dos custos por juros}

A DPC-9 estabelece as normas que se devem dar aos custos por juros a capitalizar.

Esta norma origina-se pelas seguintes razões:

a) Variedade de práticas contábeis. Algumas empresas capitalizam os juros, por exemplo, as companhias de serviços públicos; outras não os consideram como parte do custo dos ativos; e as demais, algumas vezes os capitalizam, e outras não.

b) Freqüentemente as companhias utilizam o crédito externo para financiar seus ativos fixos. Devido a isto, os juros dos empréstimos destinados à aquisição de "determinados ativos" são um elemento normal dos custos dos ativos.

Este Pronunciamento é baseado no FASB 34 da Comissão de Normas de Contabilidade Financeira dos Estados Unidos da América. 
Este pronunciamento estabelece normas de contabilidade e relatório financeiro para a capitalização do custo por juros, como parte do custo histórico na aquisição de certos ativos. Para fins deste pronunciamento, "O custo por juros inclui o juro reconhecido em obrigações, com taxas explícitas de juros, juros atribuídos a certos tipos de contas por pagar e juro relacionado a um arrendamento financeiro de capital determinado."

A DPC-9 estabelece no parágrafo 6 o seguinte:

O custo histórico para a aquisição de um ativo inclui os custos necessariamente incorridos, para levar o bem às condições necessárias para seu uso proposto. Se um ativo necessita um período de tempo para realizar as atividades necessárias para levar o bem a essa condição, os custos por juros incorridos durante esse período, como resultado de despesas efetuadas para o ativo, são parte do custo histórico da aquisição do ativo.

Deve-se considerar o estabelecido no parágrafo 15 do Terceiro Boletim de Atualização da DPC-10, que diz o seguinte:

O impacto da inflação é refletido nos custos de financiamento (juros). Não é adequado ajustar os investimentos em ativos fixos financiados com empréstimos e também capitalizar no valor desses ativos a parcela dos custos de financiamento que compensam a inflação durante o mesmo período. Esta parcela dos custos de financiamento reconhece-se como uma despesa no período no qual se incorrem os custos. Somente podem capitalizar-se como ativo fixo a parcela de juros que excede à taxa de inflação, geralmente denominada taxa real de juros. Este 
procedimento é aplicável inclusive nos períodos de construção ou instalação prévios à colocação em atividade dos ativos.

A DPC-9 estabelece o seguinte no parágrafo 7 e 8:

Os objetivos da capitalização de juros são:

a) obter uma medida do custo de aquisição, que reflita mais acertadamente o investimento total da empresa no ativo;

b) debitar um custo que se relaciona com a aquisição de um recurso, que beneficiará períodos futuros contra as receitas dos períodos beneficiados.

Em geral, o custo dos juros é capitalizável para todos os ativos que requerem um período de tempo para atingir seu uso proposto ("período de aquisição").

A DPC-9 estabelece nos parágrafos 9 e 10 o seguinte:

Ativos que classificam para capitalização de juros:

a) Ativos que são construídos ou de outra maneira produzidos para ser usados pela própria empresa (incluindo ativos construídos ou produzidos para a empresa por outros, efetuando-se depósitos ou pagamentos para eles no decorrer da construção.)

b) Ativos para a venda ou arrendamento que são construídos ou de outra maneira fabricados em processos não repetitivos. (Exemplo: barcos.) 
O custo por juros não será capitalizado para inventários confeccionados rotineiramente.

Os juros não serão capitalizados para os seguintes tipos de ativos:

1) Ativos cuja construção foi concluída e que estão incorporados ou preparados para ser usados nas atividades rentáveis da empresa.

2) Ativos que não estão sendo utilizados nas atividades normais da empresa e que não são submetidos às atividades necessárias para sua preparação.

A DPC-9 estabelece no parágrafo 12 o seguinte:

"O montante do custo por juros que será capitalizado para ativos que classificam, será aquela parcela do custo por juros incorridos durante os períodos de aquisição do ativo, que teoricamente houvessem podido evitar-se se não tivessem feito despesas para os ativos".

A DPC-9 estabelece no parágrafo 17 o seguinte:

"O Período de Capitalização vai se iniciar quando existam três condições:

a) a entidade incorreu em despesas para o ativo;

b) estão progredindo as atividades necessárias para colocar o ativo para seu uso proposto;

c) a entidade incorreu em custos por juros. 
O termo "atividades" compreende, além da construção física, todos as atividades requeridas como administrativas, técnicas, etc., para preparar o ativo para seu uso proposto".

A DPC-9 estabelece no parágrafo 21 o seguinte:

"Deve-se informar nas demonstrações financeiras ou nas notas a seguinte informação:

a) Em um período contábil onde não há capitalização de custo por juros, o montante de custo por juros incorrido e debitado a despesas durante o período.

b) Em um período contábil no qual algum custo por juros incorridos durante o período e o montante que foi capitalizado.

A informação relacionada com a capitalização de juros é revelada nas notas às demonstrações financeiras na seção de normas contábeis e na seção do detalhe dos itens respectivos". 


\section{5.- LEASI NG}

\section{1.- NORMAS INTERNACIONAIS DO LEASING}

49،O IASC (“International Accounting Standards Committee”) possui uma Norma Internacional de Contabilidade sobre o assunto, a NIC $\mathrm{n}^{0} 17$ "Contabilização dos Arrendamentos", que foi editada em março de 1982 para entrar em vigor em $1^{0}$ janeiro de 1984 . Em 1994, o IASC deu novo formato à norma.

Segundo essa norma, arrendamento mercantil financeiro é aquele em que os riscos e os benefícios decorrentes do ativo arrendado são transferidos ao arrendatário, independentemente de a propriedade legal ficar com o arrendador. Os demais são arrendamentos mercantis operacionais.

O objetivo do IASC é separar como arrendamentos financeiros àqueles em que se tem de fato uma caracterização de compra e venda a prazo com financiamento da empresa de arrendamento mercantil. E como arrendamento operacional àqueles em que se tem a caracterização de efetivo aluguel.

O IASC deseja que se respeitem os princípios contábeis que exigem a obediência à essência econômica quando a forma provocar uma figura contratual diferente da efetiva realidade.

\footnotetext{
${ }^{49}$ IOB. Temática Contábil. Arrendamento mercantil (leasing) Contabilização na arrendatária. (1, 2 e 3 partes) São Paulo, 1998.
} 
$\mathrm{Na}$ sua NIC 17 o IASC enumera "exemplos de situações em que um arrendamento seria normalmente classificado como arrendamento financeiro:

a) o arrendamento transfere a propriedade do ativo ao arrendatário no fim do período de arrendamento;

b) o arrendatário tem a opção de comprar o ativo por um preço que se espera ser tão abaixo do justo valor na data em que a opção se torna exercível, que, no início do arrendamento, já é razoavelmente certo que a opção será exercida;

c) o prazo de arrendamento é pela maior parte da vida útil do ativo. O título de propriedade poderá ou não ser eventualmente transferido;

d) o valor atual no começo do arrendamento dos pagamentos mínimos é basicamente maior ou igual ao valor justo do ativo arrendado menos os subsídios e créditos fiscais para o arrendador naquela data. O título poderá ou não ser eventualmente transferido".

As regras do IASC dizem na parte contábil relativa aos arrendatários:

"12. As transações e os outros eventos devem ser contabilizados e apresentados de acordo com a sua substância e realidade financeira, e não meramente de acordo com a sua forma legal. Embora a forma legal de um contrato de arrendamento financeiro não transfira ao arrendatário o título de propriedade do ativo arrendado, no caso dos arrendamentos financeiros a substância e a realidade financeira são que o arrendatário adquire os benefícios 
econômicos do uso do ativo arrendado durante a maior parte da sua vida útil, em troca da obrigação de pagar por esse direito uma importância próxima do valor justo do ativo e os respectivos encargos financeiros.

13. Se tais transações de arrendamento não estão refletidas no balanço do arrendatário, os recursos econômicos e o nível de obrigação de uma empresa estão declarados a menos, assim distorcendo os coeficientes financeiros. Portanto, é apropriado que um arrendamento financeiro seja registrado no balanço do arrendatário tanto como um ativo, como por uma obrigação a pagar referente aos futuros aluguéis".

\section{O IASC determina:}

"Arrendamentos financeiros

11. "Os arrendamentos financeiros devem ser refletidos no balanço do arrendatário como um ativo e um passivo de importâncias iguais, no início do arrendamento, ao valor justo dos bens arrendados, deduzidas as subvenções e créditos fiscais em favor do arrendador ou, se for menor, ao valor atual dos pagamentos mínimos contratuais. Ao calcular o valor atual dos pagamentos mínimos contratuais, o fator de desconto é a taxa de juros implícita no arrendamento, se for praticável apurá-la; caso contrário, usa-se a taxa de financiamento do arrendatário.

14. Os aluguéis devem ser desdobrados em encargos financeiros e redução do passivo. Os encargos financeiros devem ser atribuídos aos períodos contábeis 
durante o prazo do arrendamento, para produzir uma taxa periódica constante de juros sobre o saldo remanescente do passivo em cada período. Pode-se usar alguma forma aproximativa.

16. O arrendamento financeiro dá origem a uma despesa de depreciação do ativo, assim como a um encargo financeiro em cada período contábil. A política de depreciação aplicada aos bens arrendados deve ser consistente com a referente aos bens depreciáveis próprios, e a despesa de depreciação deve ser calculada nas bases constantes da NIC 4, Contabilização da Depreciação e, da NIC 16, Ativo Imobilizado. Se não houver razoável certeza de que o arrendatário adquirirá a propriedade dos bens no fim do prazo de arrendamento, os bens deverão ser totalmente depreciados durante o prazo do arrendamento ou a sua vida útil, predominando o prazo que for menor.

\section{Arrendamentos operacionais}

19. O débito à despesa, decorrente de um arrendamento operacional, deve ser a despesa de aluguel no período contábil, reconhecida numa base sistemática que seja representativa do fator tempo do benefício para o usuário".

Em 1976 foi publicada pelo FASB a Exposição 꾸13, que em seu parágrafo 60, diz: "Um contrato de leasing que transfere substancialmente todos os benefícios e riscos incidentes sobre o direito de uso dos bens arrendados, deve ser contabilizado como uma aquisição de ativo e ocorrência de uma obrigação pela arrendatária, e como venda ou financiamento pela arrendadora, uma vez que 
o efeito econômico entre as partes é similar a uma operação de compra e venda a prazo".

“O FASB nº 13 especifica que um contrato de leasing será classificado como "financeiro" e, conseqüentemente, capitalizado como ativo no Balanço Geral da arrendatária, se atender a uma das condições seguintes:

a) A propriedade do bem será transferida ao final do contrato à arrendatária.

b) O contrato de leasing apresenta uma cláusula de opção para a compra do bem arrendado por um valor significativamente inferior ao valor de mercado.

c) O prazo do contrato cobre pelo menos $75 \%$ do prazo de vida útil econômica do bem arrendado.

d) O valor presente dos pagamentos mínimos do leasing é igual ou superior a $90 \%$ do valor de mercado do bem.

Esses contratos que classificam como leasing financeiro na arrendatária serão considerados como "leasing financeiro direto" ou "leasing venda" na arrendadora se forem atendidos mais dois critérios:

a) A cobrança dos pagamentos mínimos do leasing é razoavelmente prognosticável.

b) Não há incertezas relevantes envolvendo os custos adicionais futuros a serem incorridos pela arrendadora. 
Há uma posição simétrica entre as duas entidades envolvidas na transação: direitos a receber na arrendadora representam obrigações na arrendatária, bem como as receitas de arrendamento correspondem às despesas de arrendamento na arrendatária”.

\section{2.- ARGENTINA ${ }^{50}$}

No tratamento do Leasing, há uma nova Lei (25248) que substitui a anterior Lei (24441).

De acordo com Massa e Godoy no seu trabalho sobre "Leasing" apresentado no Congresso Nacional de Profissionais em Ciências Econômicas, a nova Lei tem vantagens nos seguintes campos: cessão de contratos, securitização, aspectos fiscais e benefícios do Leasing.

Os principais ativos adquiridos por leasing são: os investimentos em maquinaria industrial $(49,10 \%)$ e as telecomunicações $(31,30 \%)$; outros itens de um dígito são: hardware, software, imóveis, etc.

O Leasing na Argentina está gravado pelo "Imposto às Receitas" e o "Imposto ao Valor Agregado IVA".

Segundo Massa, o Leasing possui o principal benefício de permitir a atualização técnica sem maior investimento, não afeta a liquidez, é uma fonte de financiamento e possui uma avaliação de risco do crédito mais flexível. Para o

\footnotetext{
${ }^{50} \mathrm{http}: / / w w w . f a c p c e . c o m . a r /$
} 
fornecedor, tem a possibilidade de oferecer produtos, mais o financiamento deles, permite também cobrar a vista as operações e, portanto, incrementar o volume de suas vendas.

O tratamento fiscal do leasing financeiro é do reconhecimento como bens adquiridos desde o momento inicial da operação pelo contratado, sendo considerados como uma compra com financiamento e fazendo parte de seu ativo, depreciados de acordo com as normas gerais que regem as empresas. $E$ no caso de leasing operacional, os débitos devem ser registrados como despesa de aluguel para o período contábil.

RT no 18 Normas contábeis profissionais: desenvolvimento de alguns assuntos de aplicação particular ${ }^{51}$

(Vai entrar em vigência em 2001)

De acordo com esta norma, "arrendamento é um acordo pelo qual uma pessoa (o arrendador) cede a outra (o arrendatário) o direito de uso de um ativo durante um tempo determinado, em troca de uma ou mais somas em dinheiro (prestação).

Arrendamento financeiro: é um tipo de arrendamento que transfere substancialmente todos os riscos e vantagens à propriedade do ativo arrendado, cuja titularidade pode ser transferida ou não. Em contraprestação o arrendatário obriga-se a efetuar um ou mais pagamentos que cobrem o valor corrente do ativo e as despesas financeiras correspondentes. 
Arrendamento operacional: é qualquer arrendamento que não seja financeiro.

Valor residual não garantido: é a parte do valor residual do ativo arrendado, cuja realização não está assegurada ou fica garantido exclusivamente por um terceiro relacionado com o arrendador.

\section{Tipos de arrendamento:}

A caracterização de um arrendamento como financeiro ou operacional deve basear-se mais na substância da operação que na forma do contrato.

Situações em que um arrendamento poderia classificar-se como financeiro:

- o contrato transfere a propriedade do ativo ao arrendatário no final do arrendamento.

- o arrendatário tem a opção de comprar um ativo a um preço que seja mais baixo que o valor corrente esperado na data de exercício da opção, de maneira que, no início do arrendamento, seja razoavelmente seguro que a opção vai realizar-se;

- o prazo do arrendamento cobre a parte principal da vida econômica do ativo;

\footnotetext{
${ }^{51}$ http://www.facpce.com.ar/
} 
- no início do arrendamento, o valor descontado das prestações mínimas equivale substancialmente ao valor corrente do ativo arrendado;

- a natureza dos ativos arrendados faz que somente o arrendatário possa utilizá-los sem incorporar maiores modificações;

- o arrendatário tem a possibilidade de prorrogar o arrendamento durante um segundo período, com prestações substancialmente menores que as do mercado.

O arrendamento de terrenos se presume operacional, quando o contrato não previr que a titularidade do ativo passe ao arrendatário durante sua vigência ou a seu vencimento.

\section{Arrendamentos Financeiros}

Contabilidade do arrendatário: os arrendamentos financeiros devem ser tratados do mesmo modo que uma compra financiada, colocando como preço da transferência do bem arrendado o montante que seja menor entre:

- o estabelecido para a compra do bem a vista; e

- a soma dos valores descontados das prestações mínimas do arrendamento ( desde o ponto de vista do arrendatário). 
Para o cálculo dos valores descontados será utilizada a taxa de juros implícita do arrendamento. Se o arrendatário não puder determinar, utilizará a taxa de juros que deveria pagar por incrementar seu passivo.

Contabilidade do arrendador: os arrendamentos financeiros devem reconhecer-se como uma conta por cobrar, por um montante igual ao valor descontado da soma de:

- as prestações mínimas pelo arrendamento (desde o ponto de vista do arrendador); e

- qualquer valor residual não garantido.

Para o cálculo do valor descontado será utilizada a taxa de juros implícita do arrendamento.

A mensuração do valor residual não garantido será revisada periodicamente. De produzir-se sua desvalorização permanente será revisada a distribuição dos resultados financeiros ao longo do prazo do arrendamento e será reconhecido um resultado por qualquer diferença entre:

- a mensuração original mais os resultados financeiros realizados, calculados considerando o valor residual anteriormente determinado, e

- a mensuração original mais os resultados financeiros realizados, calculados considerando o novo valor residual. 


\section{Arrendamentos operacionais}

As contraprestações que devem pagar-se pelo uso de um bem em um acordo de arrendamento operacional devem colocar-se aos períodos em que se geraram as correspondentes obrigações".

\section{3.- BRASIL}

a) Conselho Federal de Contabilidade - CFC

O CFC não emitiu nenhuma norma regulamentando os procedimentos contábeis em relação ao arrendamento mercantil ou leasing.

\section{b) Lei das Sociedades por Ações ${ }^{52}$}

A Lei $n^{0}$ 6.404/76, alterada pela Lei $n^{0}$ 9.457/97, no seu artigo $176 \S 5^{0}$, pronuncia-se sobre a necessidade de colocar em notas explicativas os critérios de avaliação dos elementos patrimoniais, os ônus reais constituídos sobre elementos do ativo, e sobre as obrigações em longo prazo.

No seu artigo 177 determina que as sociedades anônimas (e a legislação fiscal estendeu essa obrigatoriedade às demais pessoas jurídicas tributadas com base no lucro real - art. 220 do RIR/94) precisam dar obediência "aos preceitos da legislação comercial e dessa lei e aos princípios de contabilidade geralmente aceitos". 


\section{c) Fisco}

De acordo com a Lei no 6.099/74, art. 10, deve ser observado o seguinte:

"Art. 10 - O tratamento tributário das operações de arrendamento mercantil reger-se-á pelas disposições desta Lei.

Parágrafo único - Considera-se arrendamento mercantil a operação realizada entre pessoas jurídicas, que tenha por objeto o arrendamento de bens adquiridos a terceiros pela arrendadora, para fins de uso próprio da arrendatária e que atendam às especificações desta.

para pessoas físicas ou jurídicas, no papel de arrendatários;

por instituições específicas (empresas de leasing, também chamadas de sociedades de arrendamento mercantil) no papel de arrendadoras e bancos múltiplos com carteira de arrendamento mercantil;

a empresa de leasing adquire o bem de um fornecedor (fabricante ou revendedor), escolhido de acordo com as especificações do cliente (arrendatário), com a finalidade exclusiva de arrendá-lo a este mesmo cliente."

"Art. 30 - Serão escriturados em conta especial do ativo imobilizado da arrendadora os bens destinados a arrendamento mercantil".

"Art. 50 - Os contratos de arrendamento mercantil conterão as seguintes disposições:

\footnotetext{
${ }^{52}$ Lei № 6.404 de 15 de dezembro de 1976 alterada pela lei ํํ⒐457 de 5 de maio de 1997. Brasília, 1997.
} 
a) prazo de contrato;

b) valor de cada contraprestação por períodos determinados, não superiores a um semestre;

c) opção de compra ou renovação de contrato, como faculdade do arrendatário;

d) preço para opção de compra ou critério para fixação, quando for estipulada esta cláusula."

As operações de leasing possuem características fiscais e tributárias bastante específicas determinadas por lei. São as mais importantes:

O valor das contraprestações, segundo a lei, é despesa operacional, devendo constar nas demonstrações financeiras da empresa arrendatária, e portanto, dedutíveis do lucro bruto para efeito do Imposto de Renda.

Durante toda a vigência do contrato, o bem arrendado constará do ativo fixo da arrendadora, pois é de sua propriedade. Não interferirá, portanto, no cálculo do imposto de renda da empresa arrendatária.

O bem ingressará no ativo fixo da empresa arrendatária, no momento da aquisição, ao final do contrato, pelo seu valor residual garantido ou pelo preço de mercado.

As pessoas físicas não poderão deduzir as contraprestações como despesa operacional. 


\section{3، Sociedade de Arrendamento Mercantil}

As operações de leasing somente podem ser realizadas por pessoas jurídicas que tenham como objeto principal de sua atividade a prática de operações de arrendamento mercantil, pelos Bancos Múltiplos com carteira de arrendamento mercantil e pelas instituições financeiras que estejam autorizadas a contratar operações de arrendamento com o próprio vendedor do bem ou com pessoas jurídicas a ele coligadas ou interdependentes.

Aplicam-se a estas sociedades as normas em vigor para as instituições financeiras em geral. A constituição e o funcionamento destas sociedades dependem de autorização do Banco Central do Brasil.

As sociedades de arrendamento mercantil devem adotar a forma jurídica de sociedades anônimas e a elas se aplicam, no que couberam, as mesmas condições estabelecidas para o funcionamento de instituições financeiras e legislação posterior relativa ao Sistema Financeiro Nacional, devendo constar obrigatoriamente de sua denominação a expressão "arrendamento mercantil".

A sociedade de arrendamento mercantil deve ter as suas Demonstrações Financeiras auditadas por Auditor Independente registrado na Comissão de Valores Mobiliários.

O Conselho Monetário Nacional está autorizado a:

\footnotetext{
${ }^{53}$ Blatt, Adriano. Leasing uma abordagem prática. Brasil, 1998. p. 15-17.
} 
a) Expedir normas que visem estabelecer mecanismos reguladores das atividades de arrendamento mercantil, inclusive excluir modalidades de operações do tratamento previsto na lei, e limitar ou proibir sua prática por determinadas categorias de pessoas físicas ou jurídicas.

b) Enumerar restritamente os bens que não podem ser objeto de arrendamento mercantil, tendo em vista a política econômico-financeira do país".

\section{Características da Contabilização:}

- $\quad$ Na Arrendadora: Serão escriturados em contas especiais do ativo imobilizado da arrendadora os bens destinados a arrendamento mercantil. A pessoa jurídica arrendadora deve manter registro individualizado que permita a verificação do fator determinante da receita e do arrendamento" ${ }^{4}$.

55 "Devem ser registradas como receitas de arrendamento as contraprestações previstas no contrato de arrendamento. Constituem despesas de arrendamento as parcelas de depreciação dos bens arrendados, ou destinados a arrendamento, assim como os encargos financeiros incidentes sobre operações passivas contratadas.

- Na Arrendatária: No Brasil, o leasing tem o seguinte tratamento: considera-se o arrendamento como um aluguel normal, o que implica a não ativação do bem recebido, o não registro no passivo exigível dos compromissos assumidos de pagamento das prestações, o registro das prestações como

\footnotetext{
${ }^{54}$ Blatt, Adriano. Leasing uma abordagem prática. Brasil, 1998. p. 17.
} 
despesas e, ao final do contrato, se a arrendatária optar por ficar definitivamente com o bem, sua ativação apenas nesse momento pelo valor contratado.

É obrigatório que a arrendatária mencione, nas notas explicativas às suas demonstrações contábeis, a existência dos contratos de arrendamento, se relevantes. Deve mencionar o valor total ainda a pagar; o prazo restante para esse pagamento e valor da prestação; condições dos pagamentos e das atualizações: IGP-M, variação cambial, etc.; natureza do bem arrendado; valor pelo qual o bem estaria registrado no ativo caso houvesse sido adquirido numa compra normal; outros.

No Brasil, a regulamentação das operações de leasing é amparada pela Lei ํㅜ 6.099/74. Se alguma arrendatária celebrar contrato de arrendamento fora dessa lei e das suas regulamentações, não poderá considerar as prestações do contrato de arrendamento como dedutíveis e precisará contabilizar a operação como se fosse compra de um bem com financiamento. As empresas arrendadora e arrendatárias são fiscalizadas pelo Banco Central”.

56“O Conselho Monetário Nacional, mediante a Resolução $n^{\circ}$ 2.309, de 28.08.96, do Banco Central do Brasil, emendada pela de $n^{\circ}$ 2.465, de 19.02.98, efetuou algumas mudanças para as arrendadoras, a classificação das operações de arrendamento mercantil em dois grupos: arrendamentos mercantis financeiros e arrendamentos mercantis operacionais, mas sem resolver os problemas

\footnotetext{
${ }^{55}$ IOB. Temática Contábil. Arrendamento mercantil (leasing) Contabilização na arrendatária, São Paulo, 1998.
} 
contábeis brasileiros, devido a que, nas arrendatárias, a contabilização tanto de uma operação quanto da outra continua sendo como se fossem aluguéis.

As Resoluções mencionadas definem o seguinte:

Art. $5^{0}-$ Considera-se arrendamento mercantil financeiro a modalidade em que:

I - as contraprestações e demais pagamentos previstos no contrato, devidos pela arrendatária, sejam normalmente suficientes para que a arrendadora recupere o custo do bem arrendado durante o prazo contratual da operação e, adicionalmente, obtenha um retorno sobre os recursos investidos;

II - as despesas de manutenção, assistência técnica e serviços correlatos à operacionalidade do bem arrendado sejam de responsabilidade da arrendatária;

III - o preço para o exercício da opção de compra seja livremente pactuado, podendo ser, inclusive, o valor de mercado do bem arrendado.

e

Art. 6ํㅡ - Considera-se arrendamento mercantil operacional a modalidade em que:

I - as contraprestações a serem pagas pela arrendatária contemplem o custo de arrendamento do bem e os serviços inerentes a sua colocação à

\footnotetext{
${ }^{56}$ IOB. Temática Contábil. Arrendamento mercantil (leasing) Contabilização na arrendatária (3 e última parte) São Paulo. 1998.
} 
disposição da arrendatária, não podendo o valor presente dos pagamentos ultrapassar $90 \%$ (noventa por cento) do custo do bem;

II - o prazo contratual seja inferior a $75 \%$ (setenta e cinco por cento) do prazo de vida útil econômica do bem;

III - o preço para o exercício da opção de compra seja o valor do mercado do bem arrendado;

IV - não haja previsão de pagamento de valor residual garantido.

§ 3ำ - A manutenção, a assistência técnica e os serviços correlatos à operacionalidade do bem arrendado podem ser de responsabilidade da arrendadora ou da arrendatária".

\section{d) IBRACON ${ }^{57}$}

De acordo com o Pronunciamento VII há, com maior freqüência, contratos de arrendamento de bens do imobilizado. Em certos casos, em virtude de cláusulas contratuais que estabelecem opção de compra ou garantem a transferência da propriedade do bem para o arrendatário no fim do contrato, ou transferem a posse do bem durante um período substancial da sua vida útil, os contratos de arrendamento assemelham-se a uma compra financiada dos bens objeto dos mesmos. Nesses casos, levando-se em consideração a realidade econômica subjacente, é mais lógico proceder a contabilização do valor implícito da transação como imobilizado e, os pagamentos futuros, como cancelamento da

\footnotetext{
${ }^{57}$ IBRACON. Princípios Contábeis. São Paulo, 1994. p.87 - 92.
} 
dívida contraída. Os juros da operação e a depreciação alocar-se-ão aos resultados de cada período.

O tratamento do Leasing está sendo revisado através de um provável novo Pronunciamento.

\section{e) CVM}

58“"De acordo com o Parecer de Orientação nº 15, de 28-12-87, em seu item 4, fala sobre as notas explicativas referentes a operações de arrendamento mercantil, ressaltando o aspecto informativo da Contabilidade, a qual deve basearse, se necessário, na essência econômica em vez de na forma jurídica da qual se reveste, devido a que no Brasil as operações de arrendamento mercantil, na essência, caracterizam-se como operações de financiamento, conhecidas como arrendamento financeiro.

Segundo o item 4 desse Parecer, existem distorções nas demonstrações financeiras devido a que são omitidos os valores dos ativos aplicados nas atividades da companhia e os passivos correspondentes, além de se antecipar (e não evidenciar) despesas de depreciação sob a forma de despesa de arrendamento.

Devido a isto, a CVM passou a requerer das companhias de capital aberto arrendatárias a evidenciação, em nota explicativa, das informações de contratos de arrendamento, informando o valor do ativo e do passivo que existiriam caso tais contratos tivessem sido registrados como operações de financiamento". 


\section{4.- COLÔMBIA ${ }^{59}$}

"Os Contratos de Leasing estão normatizados na Colômbia pelo ART.1271-Adicionado. L.233/95 art.88. Os Contratos de arrendamento financeiro ou Leasing com opção de compra que sejam realizados a partir do $1^{\underline{0}}$ de janeiro de 1996 serão normatizados para efeitos contábeis e tributários pelas seguintes regras.

- Os contratos de arrendamento financeiro de imóveis, cujo prazo seja igual ou superior a 60 meses; de maquinárias, equipamentos, móveis, cujo prazo seja igual ou superior a 36 meses; de veículos de uso produtivo e de equipamento de computação, cujo prazo seja igual ou superior a 24 meses; serão considerados como um arrendamento operacional. Isto significa que o arrendatário registrará como uma despesa dedutível a totalidade do arrendamento, sem que deva registrar em seu ativo ou seu passivo, nenhuma quantidade pelo bem arrendado. Quando os imóveis incluíam terreno, a parte do contrato correspondente ao terreno será normatizado pela seguinte regra.

- Os contratos de arrendamento financeiro de imóveis, na parte que correspondam a terreno, qualquer que seja seu prazo; os contratos de "lease back", qualquer que seja o ativo fixo arrendado e o prazo; e os contratos de arrendamento financeiro de bens mencionados no item

\footnotetext{
${ }^{58}$ DA ROSA, Paulo Moreira. Op. citada. São Paulo, 1999. p. 130.

${ }^{59}$ Régimen Contable Colombiano. Bogotá, 1996. p. 304 - 306.
} 
anterior, mas cujos prazos sejam inferiores aos estabelecidos lá; terão para efeitos contábeis e tributários, o seguinte tratamento:

- No início do contrato, o arrendatário deverá registrar um ativo e um passivo pelo valor total do bem arrendado. Isto é por uma quantidade igual ao valor presente dos arrendamentos e opções de compra pactuados, calculados na data de iniciação do contrato, e na taxa pactuado no mesmo. A quantidade registrada como passivo pelo arrendatário, deve coincidir com a registrada pela arrendadora como ativo monetário na conta de bens outorgados em leasing. Quando o arrendatário faça uso do desconto do imposto às vendas, previsto no artigo 258-1 do estatuto tributário, deverá re-classificar o ativo no monto, para registrar o desconto do imposto às vendas como uma antecipação do imposto à renda;

- O valor registrado no ativo pelo arrendatário, exceto a parte que corresponda ao imposto às vendas que vai ser descontado, terá a natureza de ativo não monetário, sujeito aos ajustes por inflação. No caso que o bem seja um ativo depreciável ou amortizável, o ativo não monetário registrado pelo arrendatário será depreciado ou amortizado, usando as mesmas regras e normas que seriam aplicadas se o bem arrendado fosse de sua propriedade, ou seja, considerando a vida útil do bem arrendado. No caso que o bem arrendado seja um ativo não depreciável ou não amortizável, o arrendatário não poderá depreciar o ativo não monetário registrado na sua contabilidade. 
- Os montantes de arrendamento a cargo do arrendatário deverão se descompor na parte que corresponda a capital e a parte que corresponda a juros ou custo financeiro. A parte correspondente a capital se colocará diretamente contra o passivo registrado pelo arrendatário, como um menor valor deste. A parte correspondente a juros ou custo financeiro será uma despesa dedutível para o arrendatário.

- O contrato deve estipular o valor do bem no momento de sua celebração, incluindo o imposto sobre as vendas, como a parte do valor dos arrendamentos periódicos pactuados que correspondam a cada um dos conceitos de financiamento e amortização de capital;

- No momento de exercer a opção de compra, o valor pactuado será debitado contra o passivo do arrendatário, devendo ficar este em zero. Qualquer diferença será ajustada contra os resultados do exercício. No caso que o arrendatário não exerça a opção de compra, deverão realizar-se os ajustes na sua renda e patrimônio, deduzindo na declaração de renda do ano onde finalizou o contrato, a totalidade do saldo por depreciar do ativo não monetário registrado pelo arrendatário. O arrendador realizará os ajustes necessários, e

- Os valores determinados de acordo com os itens anteriores serão utilizados pelo arrendatário para: declarar o valor patrimonial do ativo; realizar o cálculo da depreciação, quando seja necessário; aplicar os 
ajustes por inflação; determinar o saldo do passivo e sua amortização; e, calcular o montante dos custos financeiros dedutíveis.

- Para o arrendador, em quaisquer dos casos estudados, os ativos outorgados em leasing terão a natureza de ativos monetários. O arrendador deverá incluir nas suas declarações de renda a totalidade das receitas geradas pelos contratos de arrendamento. Consideram-se receitas geradas pelo contrato de arrendamento a parte dos arrendamentos que corresponda a juros ou receitas financeiras, assim como as demais receitas geradas pelo contrato.

-O desconto do imposto às vendas do artigo 258-1, somente poderá ser usado pelo arrendatário do contrato de leasing. O imposto às vendas realizado no momento da compra do bem deverá registrar-se no caso do arrendador, como maior valor do bem outorgado em leasing, exceto quando o imposto foi pago total ou parcialmente pelo arrendatário no momento da realização do contrato. Neste caso, o arrendador registrará como ativo outorgado em leasing o valor total do bem, diminuído na parte do imposto sobre as vendas que foi pago pelo arrendatário.

- Os registros contábeis e fiscais referidos no presente artigo não afetam a propriedade jurídica e econômica dos bens arrendados, que até quando não seja realizada a opção de compra pactuada continuará sendo do arrendador. 
PAR. $1^{0}$ - Considera-se por contrato de "lease back" o contrato de arrendamento financeiro que cumpra as seguintes características:

- Que o fornecedor do bem arrendado e o arrendatário do bem sejam a mesma pessoa ou entidade. e

- Que o ativo objeto do arrendamento financeiro tenha a natureza de ativo fixo para o fornecedor.

PAR. $2^{0}-$ O presente artigo não é aplicado aos contratos de leasing internacional de helicópteros e aeroplanos de serviço público e de fumigação, aplica-se a estes o Decreto-Lei 2816 de 1991.

PAR. $3^{0}$ - Unicamente terão direito ao tratamento previsto no item $1^{0}$ do presente artigo os arrendatários que apresentem no 31 de dezembro do ano imediatamente anterior um patrimônio bruto inferior a cinco bilhões de pesos (\$5.000.000.000). Aqueles que não reúnam estes requisitos deverão submeter os contratos de leasing ao tratamento previsto no parágrafo $2^{0}$ do presente artigo. Estes valores serão ajustados de acordo com o artigo 868 do estatuto tributário.

PAR. $4^{0}-$ Todos os contratos de arrendamento financeiro ou leasing com opção de compra, que se celebrem a partir do $1^{0}$ de janeiro do ano 2006, deverão submeter-se ao tratamento previsto no item $2^{0}$ do presente artigo, independentemente da natureza do arrendatário.

Segundo o artigo 89 da Lei 223/95, os contratos de arrendamento financeiro, ou leasing, celebrados em um prazo igual ou superior a 12 anos e que 
desenvolvam projetos de infra-estrutura dos setores transporte, energético, telecomunicações, água potável e saneamento básico, serão considerados como arrendamento operacional; em conseqüência, o arrendamento poderá registrar como um gasto dedutível a totalidade do arrendamento originado, sem que deva registrar no seu ativo ou passivo soma alguma por conceito do bem objeto do arrendamento, a menos que se faça uso da opção de compra”.

\section{5.- PERU ${ }^{60}$}

De acordo com as normas vigentes no Peru, "a NIC № 17, Tratamento Contábil dos Contratos de Arrendamento, é que regula o tratamento do Arrendamento. Segundo esta norma, o arrendamento é o contrato ou acordo em que o arrendador transfere ao arrendatário, em compensação de determinada soma de dinheiro, o direito de usar um bem durante um período mutuamente acordado.

Esta norma diferencia dois tipos de arrendamento, devido a que os riscos e os benefícios inerentes ao direito de propriedade de um bem arrendado correspondam ao arrendador ou ao arrendatário.

a. Arrendamento Financeiro: Contrato que transfere substancialmente todos os riscos e benefícios inerentes ao direito de propriedade de um bem, cujo título de propriedade pode ou não se transferir no decorrer do tempo. São conhecidos

\footnotetext{
60 “Informativo Caballero Bustamante”. Manual de Consultoría Contable. Lima, 1999. p.15 - 20.
} 
como arrendamentos capitalizáveis àqueles que o arrendador considera como venda e o arrendatário considera como aquisição.

b. Arrendamento Operacional: são verdadeiros arrendamentos ou contratos de aluguel, onde não pode pensar-se que o bem arrendado foi vendido pelo arrendador ao arrendatário.

Não obstante o anterior, para efeitos fiscais, o arrendamento financeiro é considerado um arrendamento operacional, de acordo com o estabelecido pelo Decreto Legislativo № 299 e o regulamento Decreto Supremo 529-84-EFC. Estas normas dispõem contrariamente ao exposto na NIC № 17 que a arrendadora mantém a propriedade dos bens no arrendamento financeiro e que a empresa arrendatária deve colocar a resultados os montantes realizados. Pode pensar-se que a NIC № 17, não é aplicável no Peru, mas o campo de aplicação desta norma é muito extenso e somente há certa limitação na parte correspondente ao Arrendamento Financeiro".

\section{6.- VENEZUELA ${ }^{61}$}

"A Declaração de Princípios de contabilidade (DPC) 14 é a norma que regulamenta o Leasing na Venezuela.

Este pronunciamento é elaborado tomando como antecedentes a NIC 17 do IASC (International Accounting Standards Committee) e o FAS 13 e suas modificações publicadas pelo FASB (Financial Accounting Standards Board). 
O arrendamento como transação mercantil pode adotar diferentes formas; em termos gerais, o termo arrendamento inclui as seguintes pessoas:

- Arrendador: a pessoa que aluga o bem;

- Arrendatário: a pessoa que recebe o bem em arrendamento;

- Bem arrendado: é o ativo utilizado pelo arrendatário na realização de suas atividades mercantis;

Os arrendamentos podem se classificar em dois tipos:

- Arrendamento Financeiro

- Arrendamento Operacional

O Arrendamento Financeiro transfere de forma substancial todos os atributos que são conseqüências de ter um bem em propriedade com a opção de transferir de maneira definitiva a propriedade do bem alugado ao arrendatário; isto é a principal diferença em relação ao segundo tipo de arrendamento.

No arrendamento operacional não existe a mudança da propriedade do bem arrendado e paga-se uma quantidade determinada pelo uso do bem alugado.

A forma legal das operações determina também de maneira importante a modalidade de registro das operações.

A DPC-14 estabelece nos parágrafos 8 a 10 o seguinte:

Contabilização dos arrendamentos pelo arrendatário

\footnotetext{
${ }^{61}$ Carpio, Fernando Catacora. Op. citada. Caracas, 1999.
} 
Arrendamento Financeiro:

8. Um arrendamento financeiro deve-se refletir na contabilidade do arrendatário através de um registro de um ativo e de um passivo, pelo valor razoável do ativo arrendado no início do arrendamento, excluindo os subsídios e os créditos fiscais que pode receber o arrendador, ou quando resulte inferior, o valor presente do investimento bruto do arrendador calculado com a taxa de juros implícita no arrendamento, ou quando não é possível obter a taxa de juros indicada no contrato de arrendamento.

9. As prestações de amortização do arrendamento devem ser divididas entre a parte que corresponde às despesas de financiamento e a parte correspondente à amortização do passivo. A despesa de financiamento deve-se distribuir entre os períodos do arrendamento para se obter uma taxa periódica constante de juros sobre o saldo do passivo de cada período. É possível aplicar algum método de aproximação.

10. O arrendamento financeiro origina a depreciação do ativo, assim como uma despesa financeira em cada período contábil. A depreciação para os ativos arrendados deve estar de acordo com os ativos depreciáveis próprios. Quando não exista uma certeza razoável de que a propriedade do ativo vai passar ao arrendatário no fim do período do arrendamento, o ativo deve-se depreciar totalmente no que resulte menor entre o período de arrendamento e a vida útil do ativo.

A DPC-14 estabelece no parágrafo 11 o seguinte: 
11. O cânon do arrendamento deve ser debitado nos resultados em cada período contábil onde corresponda ser pago.

A DPC-14 estabelece nos parágrafos 21 a 26 o seguinte:

Nas demonstrações financeiras do arrendatário

21. Deve-se informar o montante dos ativos que estão em arrendamento financeiro na data de cada balanço. Os passivos relacionados com esses ativos arrendados devem-se mostrar em separado, diferenciando as parcelas a curto e longo prazo.

22. Deve-se informar os compromissos correspondentes a arrendamentos operacionais ainda não pagos, proporcionando os montantes e os períodos de vencimento dos pagamentos.

23. Deve-se informar qualquer restrição importante, opções de compra ou renovação, rendas e outras contingências derivadas do arrendamento.

Nas demonstrações financeiras do arrendador

24. Na data de cada balanço deve-se informar o investimento bruto em arrendamento financeiro, assim como a receita financeira não realizada, diferenciando as parcelas a curto e longo prazo.

25. Deve-se informar a base utilizada para distribuir a receita. 
26. Deve-se informar o montante dos ativos fixos outorgados em arrendamento operacional, agrupados por tipos principais, junto com suas depreciações acumuladas na data de cada balanço". 


\section{6.- ATI VO DI FERI DO}

\section{1.- ARGENTINA}

O grupo de Ativo Diferido não existe na Argentina, os gastos préoperacionais, de organização, marcas e patentes, goodwill e similares são considerados como Ativos Intangíveis.

$\mathrm{Na}$ Argentina, os itens que representam despesas pré-operacionais, despesas de pesquisa que estão alocadas no Ativo Intangível são avaliadas segundo a RT $n^{0}-17^{62}$ ao custo original menos a depreciação acumulada; e são amortizadas em cinco anos devido a que sua vida útil não é superior a esses anos.

\section{2.- BRASIL}

\section{a) Conselho Federal de Contabilidade - $\mathrm{CFC}^{63}$}

Segundo a NBC-T - 4 - Da Avaliação Patrimonial:

4.2.8.1: "Os componentes do ativo diferido são avaliados ao custo de aplicação, atualizado monetariamente, deduzido das respectivas amortizações, calculadas com base no período que serão auferidos os benefícios deles decorrentes a partir do início da operação normal. A baixa do valor aplicado deve

\footnotetext{
${ }^{62} \mathrm{http}: / /$ facpce.com.ar

${ }^{63}$ CFC. Princípios Fundamentais de Contabilidade e normas brasileiras de contabilidade. São Paulo, 1995. p. 143.
} 
ser registrada quando cessarem os empreendimentos que integravam ou restar comprovado que estes não produzirão resultados suficientes para amortizá-los."

\section{b) Lei das Sociedades por Ações ${ }^{64}$}

O item V do art. 179 da Lei das Sociedades por Ações define que, no Ativo Diferido, serão classificadas:

"as aplicações de recursos em despesas que contribuirão para a formação do resultado de mais de um exercício social, inclusive os juros pagos ou creditados aos acionistas durante o período que anteceder o início das operações sociais".

A avaliação do Ativo Diferido, de acordo com o art. 183 da Lei n 6.404/76, será feita pelo valor do capital aplicado, deduzido do saldo das contas que registrem sua amortização.

A esse respeito deve entender-se como capital aplicado o valor dos gastos realizados.

A amortização desses ativos deverá ser feita segundo o $\S 3^{0}$ do art. 183 da Lei no 6.404/76:

"em prazo não superior a dez anos, a partir do início da operação normal ou do exercício em que passem a ser usufruídos os benefícios deles decorrentes, devendo ser registrada a perda do capital aplicado quando abandonados os

\footnotetext{
${ }^{64}$ Lei $\mathrm{N}^{0} 6.404$ de 15 de dezembro de 1976 alterada pela Lei $\mathrm{n}^{0} 9.457$ de 5 de maio de 1997. Brasília, 1997. p. $269-270$.
} 
empreendimentos ou atividades a que se destinavam, ou comprovado que essas atividades não poderão produzir resultados suficientes para amortizá-los".

\section{c) Comissão de Valores Mobiliários - $\mathrm{CVM}^{65}$}

Através da "Deliberação CVM nº 29, de 5-2-1986, a Comissão de Valores Mobiliários aprovou e referendou o pronunciamento do Ibracon sobre a Estrutura Conceitual Básica da Contabilidade, que menciona:

"Todas as despesas e perdas ocorridas em determinado período deverão ser confrontadas com as receitas reconhecidas nesse mesmo período ou a ele atribuídas, havendo alguns casos especiais:

a. os gastos de período em que a entidade é total ou parcialmente préoperacional. São normalmente ativados para amortização como despesas a partir do exercício em que a entidade, ou a parte do ativo, começar a gerar receitas;

b. a parcela dos gastos dos departamentos de pesquisa e desenvolvimento que superar o montante necessário para manter o setor em funcionamento, independentemente do número de projetos em execução.

Todo o gasto incremental necessário para determinado projeto poderá ser ativado e, quando o projeto iniciar a geração de receitas, amortizado contra as receitas. Os gastos diferidos que não vierem a gerar receitas deverão ter seus valores específicos descarregados como perda no período em que se caracterizar

\footnotetext{
${ }^{65}$ Da Rosa, Paulo. Op. citada. São Paulo, 1999. p.134.
} 
a impossibilidade da geração de receita ou o fracasso ou desmobilização do projeto".

O art. 60 da Instrução CVM n-191, de 15-7-1992, define que "os elementos do ativo permanente são itens não monetários". O art. $7^{0}$ da mesma Instrução estabelece que "os itens não monetários devem ser registrados por seu valor presente na data de sua aquisição ou formação".

\section{d) Instituto Brasileiro de Contadores - Ibracon ${ }^{66}$}

No seu pronunciamento $\mathrm{n}^{\circ} \mathrm{VIII}$ - Diferido, enumera os seguintes aspectos:

a) "Os direitos classificados no ativo diferido devem ser avaliados ao custo. Esse custo deve ser rateado, através de amortização, entre os diversos períodos beneficiados.

b) Se, em qualquer circunstância, houver dúvidas quanto à recuperação das despesas diferidas com lucros de períodos futuros, ou quanto à continuidade da entidade em regime operacional, os montantes ativados deverão ser imediatamente amortizados na sua totalidade".

\section{e) Fisco}

67“O Decreto-lei nํ⒈598/77, que estabeleceu normas de direito tributário para adaptar a legislação do imposto sobre a renda às inovações da lei de sociedades por ações no $\S 1^{0}$ de seu art. 15 , definindo o tratamento fiscal a ser

\footnotetext{
${ }^{66}$ IBRACON. Princípios Contábeis. São Paulo, 1994. p.93 - 100.

${ }^{67}$ Da Rosa, Paulo. Op. citada. São Paulo, 1999. p.135.
} 
dado aos ativos diferidos mencionados no item VI do art. 179 da Lei $n^{0}$ 6.404/76, assim se expressa:

"1ำ poderão ser amortizados os encargos e as despesas, registrados no ativo diferido, que contribuirão para a formação do resultado de mais de um exercício social, tais como:

a. os juros durante o período de construção e pré-operação;

b. os juros pagos ou creditados aos acionistas durante o período que anteceder o início das operações sociais, ou de implantação do empreendimento inicial;

c. os custos, despesas e outros encargos com a reestruturação, reorganização ou modernização da empresa".

O Decreto $n^{0} 85.450 / 80$ que efetuou a consolidação da legislação tributária do imposto sobre a renda oferece maiores detalhes para a aplicação prática, no âmbito da escrituração fiscal, das normas citadas, estabelecendo, nos itens I e II de seu art. 209, que poderão ser amortizados".

68“"A legislação fiscal de acordo com o art. 327 do RIR/99 estabelece prazo mínimo de 5 anos para a amortização.

Qualquer que seja o critério de amortização, a empresa deve mencioná-lo em suas Notas Explicativas.

\footnotetext{
${ }^{68}$ Iudícibus, Martins, Gelbcke. Manual de Contabilidade das Sociedades por ações. São Paulo, 1999. p. 203.
} 
A contrapartida da amortização do Ativo Diferido deve ser lançada em Despesas Operacionais (conforme o caso, no custo dos produtos elaborados), e deve tal valor estar destacado na Demonstração do Resultado do Exercício ou em Nota Explicativa."

\section{3.- COLÔMBIA 69}

"Na Colômbia o Ativo Diferido está definido no ART. 67 do D.R. 2649/93:

1. Despesas antecipadas, tais como juros, seguros, arrendamentos e outros incorridos para receber no futuro serviços.

2. Gastos Diferidos, que representam bens ou serviços recebidos dos quais espera-se obter benefícios econômicos em outros períodos. Devem ser registrados como gastos diferidos os custos incorridos durante as etapas de organização, construção, instalação, montagem e colocação em atividade. As somas incorridas em pesquisa e desenvolvimento podem registrar-se como gastos diferidos unicamente quando o produto ou processo objeto do projeto cumpre os seguintes requisitos:

a) Os custos e despesas incorridos podem se identificar separadamente;

b) É factível tecnicamente e pode ser demonstrado;

c) Há planos definidos para sua produção e venda, e

d) Seu mercado futuro está razoavelmente definido.

\footnotetext{
${ }^{69}$ Régimen Contable Colombiano. Bogotá, 1996. p.317 - 321.
} 
Esses montantes podem diferir-se com relação aos vários produtos ou processos em que tenham uso alternativo, sempre que cada um deles cumpra ditas condições.

O valor histórico desses ativos, ajustado quando seja necessário devido à inflação, deve-se amortizar em forma sistemática durante o período estimado de sua recuperação.

Assim a amortização das despesas antecipadas deve-se efetuar durante o período no qual vão receber-se os serviços.

A amortização dos gastos diferidos deve-se reconhecer desde a data em que vão originar receitas, considerando que os correspondentes à organização, pré-operacionais e colocação em atividade devem-se amortizar no menor tempo entre o estimado no estudo de planejamento para sua recuperação e a duração do projeto específico que os originou e, que as melhoras a propriedades arrendadas, quando seu custo não é recuperável, devem-se amortizar no período menor entre a duração do respectivo contrato e sua vida útil.

A amortização dos gastos diferidos tais como as despesas preliminares de instalação ou organização ou de desenvolvimento, é dedutível no imposto de renda e complementares. O tempo para dita amortização é no mínimo de cinco anos, não obstante pode fazer-se em um prazo inferior se é demonstrado que pela natureza ou duração do negócio, que a amortização tenha que se realizar em um período menor. 
Os ativos diferidos reconhecem-se no início por seu valor histórico, aplicando quando for necessária a norma básica da prudência. Ademais, quando seja necessário, deve-se efetuar o ajuste que deva corresponder com relação aos itens não monetários, utilizando para isso o PAAG mensal, devido a que por sua atividade devem difundir ou emitir demonstrações financeiras de períodos intermédios. O PAAG mensal é a porcentagem de ajuste do mês, o qual é equivalente à variação percentual do índice de preços ao consumidor para receitas médias, estabelecido pelo Departamento Administrativo Nacional de Estatística DANE, registrado no mês imediatamente anterior ao mês objeto do ajuste.

Os gastos diferidos não monetários devem-se ajustar considerando as normas gerais dos ajustes sobre ativos; não obstante, o valor correspondente à contrapartida do ajuste deve-se levar como uma receita por correção monetária diferida na conta "crédito por correção monetária diferida", na qual deve-se reconhecer como correção monetária nas contas de resultado na mesma proporção em que se reconheçam tais ativos".

\section{4.- PERU}

No Peru não há Ativo Diferido, e os itens como concessões e direitos, patentes e marcas, despesas de pesquisa, despesas de exploração e desenvolvimento, despesas de estudos e projetos, despesas de promoção e préoperacionais, despesas de emissão de ações e obrigações formam parte do Ativo Intangível. 
No Peru, ${ }^{70}$ as contas que representam despesas pré-operacionais, despesas de pesquisa e que estão alocadas no Ativo Intangível são corrigidas por inflação e separadamente, sua amortização acumulada também é corrigida por inflação.

No Peru ${ }^{71}$ as despesas pré-operacionais e as despesas de pesquisa que fazem parte do Ativo Intangível são amortizadas nos períodos que sejam beneficiados por elas. Os intangíveis devem amortizar-se pelo método de linha reta; não obstante, pode-se optar por outros métodos quando se considere mais apropriado à natureza destes ativos. Não há prazo de amortização.

\section{5.- VENEZUELA ${ }^{72}$}

"A Declaração de Princípios de Contabilidade (DPC-2) emitida em abril de 1983 estabelece os princípios de contabilidade aplicáveis para o diferimento de custos e despesas de empresas ou atividades em período de desenvolvimento em um período máximo de cinco anos.

O tratamento contábil especial refere-se ao aspecto de capitalizar ou não certas despesas ou custos. Este tratamento contábil especial não exclui que a companhia deva emitir suas demonstrações financeiras de acordo com princípios de contabilidade geralmente aceitos, como uma empresa com operações contínuas normais. O pronunciamento emite as normas relacionadas com um caso

\footnotetext{
${ }^{70}$ Ivera Associados. Op. citada. Lima, 1997. p. 389.

${ }^{71}$ Rueda, Gregório. Op. citada. Lima, 1999. p. 77.

${ }^{72}$ Carpio, Fernando Catacora. Op. citada. Caracas, 1999.
} 
ou situação específica na qual encontra-se temporalmente uma entidade. Exemplos deste tipo de entidades estão nas seguintes atividades:

- Empresas de subscrição de televisão a cabo

- Empresas de exploração mineral

- Empresas de exploração de hidrocarburetos

A DPC-2 estabelece no seu parágrafo 8 o seguinte;

"8. Este pronunciamento é aplicável a todas as empresas ou atividades em período de desenvolvimento em Venezuela, cujo objetivo final seja a obtenção de um benefício. Portanto não seria aplicável aos seguintes tipos de empresas:

a) Empresas sem fins de lucro

b) Industrias extrativas (minerais e hidrocarburetos)

c) Empresas sujeitas a regras especiais, quando as disposições legais, pelas quais deve-se reger tais empresas, discordam desta Declaração".

A DPC-2 em seu parágrafo 10 declara que:

“10. Todos os custos e despesas incorridos por uma empresa em atividade em período de desenvolvimento, desde sua etapa de organização até que dita empresa ou atividade atinge sua etapa comercial ou industrial normal, devem ser capitalizados, salvo que não exista uma seguridade razoável de sua recuperação por médio de operações futuras rentáveis. Este tratamento contábil é fundamentado nas seguintes bases:

a) Os custos e despesas incorridos por uma empresa ou atividade em etapa de desenvolvimento representam um investimento com a expectativa de obter 
benefícios futuros. Estes custos deveriam considerar-se como perdas, ainda quando não atingiram sua etapa comercial ou industrial normal, se não existe uma razoável expectativa de sua recuperação através de benefícios econômicos futuros.

b) O diferimento de tais despesas e custos evita que uma entidade apresente dúvidas sobre sua continuidade, como empresa em andamento, por investir uma parte significativa de seu capital em custos e despesas normais necessários para levar a empresa ou atividade a sua etapa comercial ou industrial normal.

c) Para a aplicação dos critérios de diferimento de custos e despesas não deve haver diferenças entre uma empresa em plena operação e uma em desenvolvimento. Os custos são diferidos para associar-se com os benefícios esperados em períodos futuros e, portanto, não devem considerar-se como ativos os custos perdidos.

d) Exemplos destes ativos são as despesas de organização, despesas de emissão de obrigações, despesas de sistemas mecanizados (software), despesas de andamento de planta (aprendizado) e custos pré-operacionais.

Geralmente nas etapas iniciais não é possível determinar que os benefícios futuros sejam realizados.

Entre as circunstâncias que poderiam originar dúvidas da recuperação dos custos e despesas do período de desenvolvimento são: 
- Baixa rentabilidade da empresa ou atividade por:

- Regras no preço dos produtos terminados

- Desvalorização importante da moeda

- Aumentos significativos de preços nos insumos ou ativos, não previstos no planejamento inicial.

- Competitividade com empresas que apresentam concorrência no gerenciamento e controle dos bens ou serviços a oferecer

- Aumento nas despesas de distribuição devido à localização geográfica da fábrica ou dos clientes potenciais

- Problemas no sistema ou canais de distribuição, grande participação dos lucros do negócio por parte dos intermediários.

- Impossibilidade da empresa de atingir um nível normal de operações Situação adversa do mercado Impossibilidade de obter o financiamento".

A DPC-2 estabelece diferentes requisitos de informação e apresentação das demonstrações financeiras nos seguintes casos:

- "Apresentação de Demonstrações Financeiras e Informação adicional para Empresas em período de desenvolvimento.

- Apresentação de Demonstrações Financeiras e Informação adicional para Empresas já estabelecidas e com atividades em período de desenvolvimento. 
- Apresentação de Demonstrações Financeiras e Informação adicional para o primeiro exercício de operações normais de uma empresa que esteve em período de desenvolvimento".

Adicionalmente na norma estabelece em seu parágrafo 18:

"18. Ademais das notas usuais deveria apresentar-se a seguinte informação adicional:

a) Indicação que a empresa iniciou nesse exercício sua etapa de operação comercial ou industrial normal.

b) Capitalização e amortização adotada para os custos e despesas incorridos durante o período de desenvolvimento.

c) Detalhe dos principais conceitos dos custos e despesas capitalizados, mostrando a amortização acumulada e o montante da amortização do exercício debitada a resultados". 


\section{7.- TÉCNI CAS DE RECONHECI MENTO DA I NFLAÇÃO}

\section{1.- ARGENTINA}

A Argentina teve seu próprio sistema de elaboração de demonstrações contábeis em moeda constante, mas devido a sua situação política e econômica, foi revogada pelo Poder executivo que aprovou o Decreto 316/95 proibindo a aceitação das Demonstrações Financeiras que contenham ajustes por inflação pelos órgãos oficiais (CNV, IGJ e outros).

"A Federação Argentina de Conselhos Profissionais de Ciências Econômicas, (FACPCE) através do Centro de Estudos Científicos e Técnicos (CECyT), estabeleceu que o ajuste por inflação será obrigatório quando a inflação chegue ao 8\% anual. A inflação anual em Argentina em 1999 foi de 0,30\% e a acumulada em três anos de $1,71 \% "{ }^{73}$

A elaboração de demonstrações contábeis em moeda constante foi normatizada pela "Resolução Técnica" $n^{0} 6$, que tem como conceitos gerais os seguintes: $:^{74}$

$$
\text { "A. - Conceitos Gerais }
$$

a.1 - Alcance: Todas as demonstrações contábeis que se apresentem a terceiros devem expressar-se em moeda constante.

\footnotetext{
${ }_{73}^{73 t t p: / / w w w . f i n a n c e w i s e . c o m ~ c i t a d o ~ p o r ~ h t t p: / / w w w . f c c p v . o r g / ~}$

74 Yamamoto, Marina. Mitiyo. A Contabilidade e o Mercosul. São Paulo, 1996. p.91 - 97.
} 
a.2 - "Capital a manter"

Para determinação do resultado do período, será adotado o conceito de manutenção do capital financeiro, enfoque que considera capital, o total dos pesos investidos pelos sócios ou acionistas, medidos em moeda constante.

\section{a.3 - Unidade de medida}

A moeda constante a ser utilizada nas demonstrações contábeis deve ser a de encerramento do período.

No caso de apresentação das demonstrações contábeis comparativas, todas devem estar expressas em moeda de poder aquisitivo de encerramento do período mais recente.

B - Metodologia

b.1 - Processo seqüencial

Geralmente, o processo de atualização das demonstrações contábeis em moeda constante consiste em:

- Determinação do ativo e passivo no início do exercício do período objeto de ajuste, em moeda constante dessa data, corrigindo as contas que as compõem.

Determinação do patrimônio líquido no início do período objeto de ajuste em moeda constante dessa data, por diferença entre ativo e passivo obtido pela aplicação da norma acima. 
- Determinação em moeda de fechamento dos ativos e passivos no final do período objeto de ajuste, atualizando as contas que os compõem.

Determinação do patrimônio líquido final em moeda de fechamento do período, obtido pela diferença entre o ativo e o passivo corrigidos.

Determinação do patrimônio líquido final em moeda de fechamento do período, excluído o resultado desse período. O resultado do exercício será obtido pela diferença do Patrimônio Líquido Inicial (em moeda constante de final de período), mais as alterações havidas (exceto pelo próprio Lucro), e o Patrimônio Líquido Final, apurado pela diferença entre ativo e passivo.

- Determinação do resultado do período em moeda de encerramento, por diferença entre o Patrimônio Líquido Final (obtido pela diferença entre Ativo e Passivo) e o Patrimônio Líquido Final, excluído o resultado deste período, conforme os dois itens precedentes.

- Determinação do resultado final do período, líquido do resultado por exposição da inflação (o resultado financeiro e da manutenção) mediante a atualização das contas da Demonstração de Resultado do Período.

- Determinação do resultado por exposição a inflação (financeiro ou de manutenção) no período, por diferença entre os dois itens imediatamente citados acima. 
b.2 - Passos para a atualização das contas

Para efeito de atualização, em moeda constante, das contas ou rubricas integrantes das demonstrações contábeis, deve-se aplicar os seguintes passos:

Segregar os componentes financeiros implícitos contidos nos saldos das contas patrimoniais ou de resultados.

As contas expressas em moeda de fechamento não devem ser atualizadas.

As contas expressas em moeda de fechamento anterior ao encerramento deverão ser atualizadas em moeda da data, do seguinte modo:

- $\quad$ Eliminação dos ajustes parciais contabilizados para refletir o efeito da inflação, a fim de evitar sua duplicação.

- Determinação do momento ou período de origem das contas (anterioridade).

- $\quad$ Cálculo dos coeficientes de atualização aplicáveis.

- $\quad$ Aplicação dos coeficientes de correção dos valores das contas antigas para efeito de atualizá-los em moeda de fechamento.

- $\quad$ Em nenhum caso os valores determinados para os diversos ativos por aplicação das normas precedentes - poderá exceder a seu valor recuperável, individualmente ou em conjunto, segundo indiquem as normas contábeis. 
b.3 - Segregação de componentes financeiros implícitos

- $\quad$ Devem ser separados os componentes financeiros implícitos contidos nos saldos de ativos ou passivos, sempre que os mesmos forem relevantes e que sua estimativa possa ser obtida razoavelmente.

- A segregação dos componentes financeiros implícitos contidos nos saldos de contas de resultados poderá efetuar-se cumprindo os requisitos enunciados na norma precedente. Esta segregação é recomendável porque melhora a apresentação dos componentes que determinam o resultado do período.

b.4 - Atualização das contas

A atualização do saldo de uma conta consiste em seu agrupamento, segundo os seus diferentes momentos ou períodos de origem.

É razoável agrupar as contas por mês de origem a fim de se proceder a sua atualização. Enquanto não gerem distorções significativas, é aceitável decompor o saldo da conta em períodos maiores de um mês.

b.5 - Índice a aplicar

O índice a aplicar será o "Índice de Preços por Atacado - Nível Geral” publicado mensalmente pelo "Instituto Nacional de Estatística e Censos". 
b.6 - Coeficientes de atualização

Os coeficientes aplicáveis às diferentes contas resultam da divisão do valor do índice correspondente na data de fechamento pelo valor do índice referente à do período de origem da conta.

No caso em que as contas se agrupem em períodos de origem maiores de um mês, o coeficiente de atualização a ser aplicado será determinado, tomandose como denominador os valores médios do índice correspondente aos meses do referido período de origem.

O índice da data de fechamento é o mesmo do último mês do período, portanto, as contas do mês de encerramento não necessitam de atualização.

b.7 Valor recuperável dos ativos

A habitual comparação denominada "custo ou mercado, dos dois o menor", necessária para a avaliação final dos ativos, se entende melhor desenvolvida através da comparação entre os valores medidos em moeda de encerramento e o valor recuperável dos ativos respectivos. Por ela, e apesar de não ser um tema relativo à unidade de medida, se considera conveniente efetuar as seguintes considerações:

\section{- Conceito:}

Valor recuperável é o maior valor obtido entre o líquido de realização e o de utilização econômica. 
- Valor líquido de realização:

É a diferença entre o preço de venda de um bem, ou conjunto de bens ou serviços, e os custos adicionais diretos que foram gerados até sua comercialização inclusive.

\section{- Valor de utilização econômica}

Segundo a natureza dos bens, poder-se-á estimar o valor de utilização econômica de maneira diferente. O conceito geral é o de significado econômico que os ativos em questão têm para a entidade em função de seu ramo de atividade e da utilização que se espera. Isto pode ser medido geralmente em função do valor atual dos ingressos líquidos prováveis que, direta ou indiretamente, se produzirão, ou de outros elementos de juízo fundamentados.

\section{b.8 - Resultado pela exposição à inflação}

No esquema mais depurado de atualização da demonstração de resultados, todos seus itens se expõem em moeda de fechamento, líquidos dos efeitos dos componentes financeiros implícitos nas operações. Isto implica, com relação aos resultados financeiros e por manutenção que:

- $\quad$ O resultado por exposição à inflação compreenda o efeito desta sobre as contas monetárias (ou expostas à perda de poder aquisitivo da moeda) e nos sobre-preços ou coberturas de inflação, contidos implicitamente nas operações. 
- $\quad$ Os resultados financeiros se expressem em termos reais (isto é líquidos de sobre-preços ou coberturas de inflação.)

- $\quad$ Os outros resultados por manutenção se manifestem de modo similar ao indicado acima.

b.9 - Resultados financeiros e por manutenção (incluindo o resultado por exposição à inflação.

$\mathrm{Na}$ demonstração de resultados em moeda de fechamento, esta conta se determina por diferenças entre o resultado final do período (calculado em moeda corrente) e o subtotal das rubricas da demonstração de resultados contábeis na moeda de encerramento.

Para efeito da partida dobrada, geralmente representa a contrapartida líquida dos ajustes efetuados em todas as contas patrimoniais e de resultados que se tenham atualizado em moeda de fechamento. Essa conta da demonstração de resultados, atualizada em moeda constante, será denominada: "Resultados financeiros e por manutenção (incluindo resultados por exposição à inflação)" e compreenderá:

- $\quad$ O resultado por exposição à inflação, entendendo por tal somente o efeito da inflação sobre as contas monetárias (ou expostas a perdas do poder aquisitivo da moeda).

- $\quad$ Os outros resultados por manutenção gerados no exercício ou período. 
- Os resultados financeiros.

A CNV -Comissão Nacional de Valores adota a RT no 6.

O Poder executivo aprovou em seu Decreto 316/95 as disposições proibindo a aceitação das Demonstrações Financeiras que contenham ajustes por inflação pelos órgãos oficiais (CNV, IGJ e outros).

O referido decreto revoga as Demonstrações em Moeda Constante a partir de 04/91.

Os organismos profissionais têm questionado tal Decreto, principalmente no que tange a sua interferência em questões contábeis".

Novas mudanças segundo a $R T n^{0} 19^{75}$ em relação à $R T n^{0} 6$

"3.1. Novo título da Resolução Técnica nº 6

Demonstrações contábeis em moeda homogênea.

3.2. Seções e parágrafos que serão eliminados: Seções I (Introdução), II (Antecedentes) III (Aspectos importantes), IV.A (Conceitos gerais), IV.B.3 (Segregação de componentes financeiros implícitos), IV.B.7 (Valor recuperável dos ativos), IV.B.10 (Re-expressão do patrimônio líquido no início do primeiro exercício de aplicação), IV.B.11 (Ajuste global do patrimônio líquido no início do primeiro exercício de aplicação), IV.C (Absorção de perdas), IV.D (Divulgação),

\footnotetext{
${ }^{75}$ http://www.facpce.com.ar
} 
IV.E (Registros contábeis), IV.F (Uniformidade), IV.G (Decisões da entidade) e IV.H (Disposições transitórias).

3.3. Novo texto do parágrafo a) a seção IV.B.2 (Etapas para o ajuste das partidas)

a) Segregar os componentes financeiros implícitos contidos nos saldos das contas patrimoniais e de resultados, de acordo com a RT n- 17 (Normas Contábeis profissionais: desenvolvimento de normas de aplicação geral).

3.4. Novo texto da seção IV.B.5 (Índice que vai ser utilizado)

IV.B.5. Índice que vai ser utilizado

O índice que vai ser utilizado resultará de combinar:

a) as mensurações do índice de preços de atacado (IPM) do Instituto Nacional de Estatística e Censos até o 31 de dezembro de 1995; e

b) as mensurações do índice de preços internos de atacado (IPIM) do mesmo organismo, posteriores a essa data.

3.5. Novo título e texto da seção IV.B.8 (Resultado por exposição à mudança no poder aquisitivo da moeda).

No esquema mais depurado de ajuste da demonstração de resultados, todos seus itens são expressos em moeda de fechamento, líquidos da parcela realizada dos componentes financeiros implícitos das operações. 
O resultado por exposição à mudança no poder aquisitivo da moeda compreenderá o efeito dessa mudança sobre as partidas monetárias (ou expostas à mudança no poder aquisitivo da moeda).

3.6. Novo título e texto da seção IV.B.9 (Resultados financeiros e por posse, incluindo o resultado por exposição à mudança no poder aquisitivo da moeda).

Na demonstração de resultados ajustados em moeda de fechamento, esta partida se determina por diferença entre o resultado final do período (calculado em moeda constante tal como se indica na norma IV.B.1.f) e o sub-total dos itens da demonstração de resultados contábeis em moeda de fechamento (segundo a norma IV.B.1.g)

Por efeito da partida dobrada, geralmente representa a contrapartida líquida dos ajustes efetuados em todas as partidas patrimoniais e de resultados que foram ajustadas em moeda de fechamento. Essa partida da demonstração de resultados ajustada em moeda constante vai denominar-se "Resultados financeiros e por posse (incluindo resultados por exposição à mudança no poder aquisitivo da moeda)".

3.7. Novo título e texto da seção IV.B.12 (Patrimônio líquido e resultado do exercício)

IV.B.12. Patrimônio líquido e resultado do exercício 
O saldo de todos os componentes do patrimônio líquido no início do exercício, assim como as variações deles, ocorridas no exercício, serão ajustados em moeda de fechamento.

O resultado do exercício ou período em moeda homogênea será a diferença entre as cifras expressas em moeda de fechamento do patrimônio líquido no início e no final, que não sejam originadas em operações com os proprietários.

3.8. Nova seção IV.B.13 (Interrupção e posterior prosseguimento dos ajustes)

IV.B.13 (Interrupção e posterior prosseguimento dos ajustes)

Quando o ajuste para refletir o efeito da mudança no poder aquisitivo da moeda prossiga depois de um período de estabilidade monetária, tanto as mensurações contábeis ajustadas pela mudança no poder aquisitivo da moeda, até o momento da interrupção dos ajustes, como as que tenham datas de origem incluídas no período de estabilidade, se considerarão expressas em moeda do último mês do período de estabilidade”.

\section{2.- BRASIL}

No Brasil, as normas que regulamentaram o reconhecimento dos efeitos por inflação são: 


\section{Antecedentes históricos da Correção monetária no Brasil e}

\section{Metodologia}

\section{a) Lei das Sociedades por Ações}

76 "No Brasil foi instituída a correção monetária pelo art. 185 da Lei nº 6.404/76. Depois veio o Decreto-lei $n^{0} 1.598 / 77$, que determinava que todas as pessoas jurídicas sujeitas à tributação do Imposto de Renda com base no Lucro Real (Lucro Contábil ajustado para fins fiscais) eram obrigadas a adotar a sistemática de correção monetária então vigente pela lei societária.

Vários índices foram usados: ORTN (Obrigações Reajustáveis do Tesouro Nacional), OTN (Obrigação do Tesouro Nacional), BTN (Bônus do Tesouro Nacional), FAP (Fator de Atualização Patrimonial) e, finalmente, a UFIR (Unidade Fiscal de Referência).

Os efeitos dessa correção monetária eram refletidos nos resultados do exercício e no Balanço Patrimonial, por meio da atualização das contas do Ativo Permanente e do Patrimônio Líquido. A esquematização contábil era assim:

a) toda conta do Ativo que fosse ajustada provocaria, em contrapartida a esse débito, um crédito na conta de Correção Monetária que era classificada como conta de Resultado (nas contas retificadoras como na Depreciação Acumulada era o inverso);

\footnotetext{
${ }^{76}$ Iudícibus, Martins, Gelbcke.Op. citada. São Paulo, 2000. p.442 444
} 
b) o valor do ajuste do capital era contabilizado como crédito na Reserva de Capital e débito na conta de Correção Monetária;

c) o ajuste das demais contas do Patrimônio Líquido era feito por meio de débito na conta de Correção Monetária e crédito na respectiva conta do Patrimônio Líquido objeto de ajuste (contas redutoras do Patrimônio Líquido eram o inverso);

d) ao final do período, se a conta de Correção Monetária apresentasse saldo credor, ele corresponderia a uma receita na Demonstração do Resultado;

e) se, ao contrário, o saldo da conta de Correção Monetária fosse devedor, ele corresponderia a uma despesa na Demonstração do Resultado".

\section{b) Comissão de Valores Mobiliários}

77"Devido a distorções provocadas por este método, foi adotado o sistema Correção Monetária Integral. Por meio da Instrução CVM nº 64/87, passou-se a exigir das companhias abertas demonstrações contábeis complementares elaboradas em moeda de poder aquisitivo constante, ou seja, com correção integral.

Posteriormente, a Instrução CVM n-191/92 substituiu a Instrução nํ64/87 e instituiu a Unidade Monetária Contábil (UMC) como unidade de referência a ser utilizada pelas companhias abertas para elaboração de demonstrações contábeis em moeda de capacidade aquisitiva constante. 
A UMC veio substituir a Unidade Fiscal de Referência (Ufir), e a idéia básica era ter sempre um índice que representasse de forma adequada as variações de preços da economia brasileira.

Entre as vantagens decorrentes da aplicação da correção monetária integral destacamos que ela:

a. apresenta os efeitos da inflação em todos os elementos das demonstrações contábeis;

b. corrige saldos finais de itens não monetários (como estoques e despesas antecipadas) que não eram considerados na legislação societária;

c. determina a inclusão do ajuste a valor presente nos valores prefixados de contas a receber e a pagar".

\section{c) Fisco}

78“"Pelo art. 4ำ da Lei ํำ 9.249/95, foi revogada a correção monetária das demonstrações contábeis de que trata a Lei $n^{0}$ 7.799, de 10-7-89, e o art. 1ํํㅁ Lei nº 8.200, de 28-6-91".

\section{d) CVM}

79 “A CVM emitiu a Instrução $n^{0}$ 248, de 29-3-96, na qual, além de exigir a apresentação das informações trimestrais e demonstrações contábeis em

\footnotetext{
${ }^{77}$ Iudícibus, Martins, Gelbcke.Op. citada. São Paulo, 2000. p.442 444

${ }^{78}$ Iudícibus, Martins, Gelbcke.Op. citada. São Paulo, 2000. p.444.
} 
consonância com a Lei $n^{0}$ 9.249/95, tornou facultativa a elaboração e divulgação em moeda de capacidade aquisitiva constante.

Através do Parecer de Orientação CVM $n^{0}$ 29, de 11-4-96, foram estabelecidos os requisitos (tais como, periodicidade, conteúdo mínimo, critérios de elaboração e índice a ser utilizado) a serem levados em consideração pelas empresas que optassem por divulgar voluntariamente informações complementares.

A Lei $n^{0}$ 9.249/95 introduziu a figura dos Juros Sobre o Capital Próprio, com opção de uso da Taxa de Juros em Longo Prazo (TJLP)".

\section{f) Metodologia da Correção Integral}

- 80“É necessário a adoção do melhor índice para efetuar a atualização dos valores. O índice adotado pela Instrução CVM nº 191/192 era o da variação da Unidade Monetária Contábil (UMC), cuja expressão monetária era o indexador oficial de correção da moeda nacional.

$\mathrm{O}$ art. $3^{0}$ da Instrução supracitada esclarecia que as companhias abertas poderiam utilizar, como alternativa à variação diária do valor da UMC, sua variação média mensal ou um critério misto, sem prejuízo para a qualidade da informação, e com ajustes para que fossem adequadamente refletidas as receitas e despesas representativas das operações realizadas.

\footnotetext{
${ }^{79}$ Iudícibus, Martins, Gelbcke. Op. citada. São Paulo, 2000. p.442 444

${ }^{80}$ Iudícibus, Martins, Gelbcke.Op. citada. São Paulo, 2000. p.442 445-460.
} 
- As contas patrimoniais deveriam ser classificadas em dois grupos: contas monetárias e contas não monetárias.

Os itens monetários são compostos pelas contas de disponibilidades e de direitos e obrigações a serem liquidados com disponibilidades. Podem ser subdivididos em: 1) itens monetários puros, compostos pelas contas de valor prefixado que não contêm qualquer forma de reajuste ou atualização, como o próprio caixa em moeda nacional; 2) itens monetários prefixados, que também não têm atualização, mas que possuem embutida alguma expectativa de inflação já inserida em seu valor, como Contas a Receber de vendas a prazo; e 3) itens monetários indexados, que são as contas monetárias sujeitas a atualização por índice pós-fixado, como os empréstimos em TR ou dólar.

Os itens não monetários são todos os demais, ou seja, representam bens (estoques, imobilizado, etc.), despesas antecipadas ou diferidas (seguros a apropriar, despesas pré-operacionais, etc.), adiantamentos a serem liquidados em bens (a fornecedores, de clientes, etc.,), resultados de exercícios futuros, etc.

- Nas contas do Balanço, teremos:

a) os saldos das contas do Balanço, de maneira geral, serão divididos pela UMC do mês de fechamento do Balanço, porque estão representados pelo valor daquela data; 
b) os itens não monetários não classificados como Ativo Permanente ou Patrimônio Líquido poderão ser divididos pela UMC do mês, considerando-se sua formação próxima à data de fechamento do balanço;

c) o valor dos itens não monetários classificados como Ativo Permanente ou Patrimônio Líquido será extraído de controles individuais de quantidade de UMC.

- Nas Contas da Demonstração do Resultado

a) As contas da Demonstração do Resultado que representam despesas ou receitas correntes serão divididas pela UMC do mês de sua competência.

b) As despesas ou receitas que estiverem sendo apropriadas em virtude de itens não monetários do Balanço deverão ser apropriadas pelo valor corrigido monetariamente a partir do mês de sua formação.

c) Os ganhos e perdas nos Itens Monetários serão calculados por meio de:

Saldo anterior do Item Monetário x $\left(\frac{\text { UMC mês }(x+1)}{\text { UMC mês } x}-1\right)$

d) As despesas/receitas financeiras são obtidas pelo seguinte cálculo:

$$
\left(\frac{\text { despesa/receita financeira do mês } \mathrm{x}}{\mathrm{UMC} \text { mês } \mathrm{x}}\right)-\left(\begin{array}{c}
\text { Ganho/perda nos Itens Monetários } \\
\text { geram as correspondentes } \\
\text { despesas/receitas financeiras }
\end{array}\right)
$$


e) O resultado de equivalência patrimonial e a provisão para o Imposto de Renda calculada sobre o lucro do período podem ser obtidos da divisão do valor contabilizado no resultado pela UMC do mês, menos a variação monetária do valor já contabilizado como resultado ou provisão do período.

Imposto de Renda Diferido - Quando o Patrimônio Líquido, pela correção integral, for maior do que o fiscal, a companhia deve aprovisionar o Imposto de Renda sobre o adicional e diferi-lo. Se menor, será crédito por pagamento antecipado, desde que efetivamente recuperável.

- Os itens monetários ativos e passivos, decorrentes de operações prefixadas, devem ser traduzidos a valor presente, com base na taxa de juros vigente na data do balanço.

- Os itens não monetários, tais como estoques, imobilizados, etc., devem ser registrados pelo valor presente apurado na data de realização de cada operação. Esse registro poderá ser feito com utilização de uma conta retificadora ou diretamente por seu valor líquido”.

\section{3.- COLÔMBIA ${ }^{81}$}

"Na Colômbia, o sistema de ajustes por inflação passou por uma série de etapas antes de chegar ao atual.

\footnotetext{
${ }^{81}$ Gonzalez, Patrícia. Revisão crítica do Sistema de Correção Monetária vigente na Colômbia; sob uma perspectiva de técnica desenvolvida no Brasil. São Paulo, 1999. p.120 -140.
} 
- O objetivo do Método de Ajustes Integrais por Inflação tem por objeto permitir que as demonstrações financeiras retratem a verdadeira realidade financeira e contábil da empresa, ou seja, que seus ativos, passivos, patrimônio, receitas, custos e gastos sejam expressos até onde seja possível em valores de mercado ou muito próximos aos mesmos.

$\mathrm{Na}$ Colômbia, de acordo com normas legais vigentes, os valores que se consideram como não monetários, e que, portanto devem ser ajustados, são os seguintes:

No Ativo: os estoques, os imobilizados, os ativos em moeda estrangeira, os ativos em UPAC (Unidade de Poder Aquisitivo constante que surge como um mecanismo de financiamento de longo prazo nos anos 70 ), os gastos diferidos, a depreciação acumulada de ativos imobilizados, a amortização acumulada de ativos, os investimentos de Capital em períodos improdutivos, as ações e aportes em sociedades, intangíveis comprados.

No caso dos ativos em moeda estrangeira e ativos em UPAC, pelo fato de sofrer algum tipo de ajuste (seja pela diferença em câmbio ou pela variação monetária), foram considerados como ativos não-monetários, apesar de ter natureza monetária.

No Passivo: os passivos em moeda estrangeira, os passivos em UPAC.

No Patrimônio: o capital, o superávit de capital, a reserva legal, outras reservas, os lucros acumulados, a revalorização do patrimônio. 
Se, durante o ano, tem-se pago dividendos ou tem-se feito liberações de reservas em efetivo, estas cifras, para serem descontadas do balanço, devem ser trazidas à moeda de fim do período, ajustando-as desde o mês seguinte à data do pagamento, o que deve fazer-se igualmente para os aumentos de capital”.

Nota: Com a Lei 488 de 1998, foram eliminados os ajustes integrais por inflação fiscal para os estoques, receitas, custos e despesas. Por expressa disposição do artigo 14 desta Lei, estas mudanças têm efeitos contábeis. ${ }^{82}$

83،OS valores monetários não estão sujeitos a ajustes por inflação devido ao fato de assumir que tais valores encontram-se expressos em pesos de poder aquisitivo da data do fechamento das demonstrações financeiras.

São valores monetários: as disponibilidades, contas a receber, bônus, títulos e outros ativos móveis tidos em moeda nacional e que não tenham um reajuste pactual, diferente das ações e dos aportes em sociedades.

- Os indicadores utilizados para reajustar contas não monetárias são:

1) Porcentagem do ajuste do ano tributável (PAAG). O PAAG anual, mensal, ou mensal acumulado é equivalente à variação percentual do Índice de Preços ao consumidor (IPC) para rendas médias, calculado pelo Departamento Administrativo Nacional de Estatística (DANE).

\footnotetext{
${ }^{82}$ Lei 488 de 1998. Instituto Nacional de Contadores Públicos de Colômbia citado por http:// www.incp.org.co/

${ }^{83}$ Gonzalez, Patrícia. Op. citada. São Paulo, 1999. p. 120 -140.
} 
2) Taxa de câmbio representativa do mercado. Emprega-se para ativos e passivos expressos em moeda estrangeira.

3) Cotação da UPAC (Unidade de Poder Aquisitivo Constante). Usa-se para as contas a receber e a pagar, os títulos, os direitos, os investimentos e demais ativos e passivos expressos em UPAC.

4) Pacto Especial de Reajuste. Quando sobre uma conta a receber ou a pagar estabelece-se uma percentagem de reajuste do principal num período determinado, em consideração à perda do poder aquisitivo da moeda.

5) As valorizações de imóveis, equipamentos, e investimentos que abarcam a Avaliação Técnico, o valor em bolsa e o valor intrínseco.

\section{- Determinação do PAAG anual, mensal, mensal acumulado:}

Nos três casos, o PAAG determina-se pela variação percentual do IPC para rendas médias, certificado pelo DANE durante um período determinado..

O PAAG anual de 1997 equivale à variação percentual do IPC para rendas médias registrado entre $1^{\circ}$ de dezembro de 1996 e 30 de novembro de 1997. A fórmula é:

$$
D=\left(\frac{\text { Índice de preços do mês final }}{\text { Índice de preços do mês inicial }}-1\right) \times 100
$$

O PAAG mensal equivale à variação percentual do IPC para rendas médias, registrado durante o mês anterior ao mês objeto de ajuste. 
O PAAG mensal acumulado equivale à variação percentual do IPC para rendas médias, registrado entre meses intermédios.

\section{- Tratamento das diferenças entre o contábil e o fiscal}

As diferenças que se apresentam entre ambas bases devem ser registradas numa Conta de Ordem. Estas diferenças dão origem ao cálculo de um imposto diferido, devem ser registradas prévio cumprimento dos seguintes requisitos;

- que a diferença seja temporal;

- que a empresa se mantenha sob o princípio de going concem;

- que exista a certeza de que o imposto vigorará nos anos seguintes; e

- que o valor da diferença temporal seja suscetível de amortização futura.

\section{- Registro dos ajustes por Inflação}

\section{- Ativos não-monetários}

O ajuste se registrará como um maior valor do bem, através de um débito à conta de cada tipo de ativos pelo valor do ajuste. A contrapartida será um crédito à conta de Correção Monetária pelo mesmo valor. Não são objeto de ajuste, as contas que não têm sido produto de uma aquisição efetiva, tal como as valorizações. 
- Ajuste de ativos em moeda estrangeira, em UPAC e com pacto de reajuste

A diferença entre o valor em livros dos ativos expressos em moeda estrangeira e seu valor ajustado no último dia do ano representa o ajuste que deve-se registrar como um maior ou menor valor do ativo e como receita ou despesa financeira, segundo corresponda.

Quando uma partida do ativo tenha sido ajustada aplicando-se a taxa de câmbio vigente, o valor da UPAC ou o pacto de reajuste, o ajuste deve-se registrar como um maior valor do ativo e, em contrapartida, como uma receita financeira. Não poderá ajustar-se adicionalmente pelo PAAG no mesmo período.

\section{- Ajuste por inflação: outros ativos não monetários}

Para o caso de ativos não monetários sobre os quais não se tem determinado uma forma especial de ajuste, o procedimento a aplicar é o seguinte: (D.R. 2649/93 art. 70).

1) O custo no último dia do ano anterior dos ativos possuídos durante todo o ano deve incrementar-se com o resultado obtido de sua multiplicação pelo PAAG anual.

2) O custo dos ativos adquiridos durante o ano, assim como o de melhoras, reparações, adições e outros conceitos capitalizados durante o mesmo, deve-se incrementar com o resultado que se obtenha ao multiplicá-lo pelo PAAG mensal acumulado, entre o primeiro dia do mês seguinte àquele no qual se efetuou a 
operação e o 31 de dezembro do respectivo ano; como contrapartida, efetuar-se-á um crédito à conta de correção monetária.

3) Quanto aos ativos não monetários que foram vendidos durante o ano, seu custo de aquisição incrementa-se com o resultado que se obtenha ao multiplicar dito custo pelo PAAG mensal acumulado, desde $1^{\circ}$ de janeiro do ano ou o primeiro dia do mês seguinte àquele no qual se efetuou a compra, se foi adquirido durante o ano, e o último dia do mês no qual efetuo-se sua venda; como contrapartida, se registrará um crédito na conta de correção monetária.

Os bens depreciáveis, exauríveis ou amortizáveis possuídos desde o início do exercício, devem ser ajustados por separado, sobre o valor bruto do ativo, da mesma maneira que o valor inicial da depreciação, exaustão ou amortização. 0 ajuste sobre o valor bruto do ativo é contabilizado como um maior valor deste e, como contrapartida, será registrado um crédito na conta de correção monetária. O ajuste da depreciação, exaustão ou amortização acumulada contábil ao início do exercício é contabilizado como um maior valor desta e, como contrapartida, realiza-se um débito na conta de correção monetária. O valor dos bens ajustados e o das depreciações, exaustões e amortizações devidamente ajustadas devem apresentar-se por separado nas demonstrações financeiras.

5) A despesa por depreciação, exaustão ou amortização contábil do respectivo ano é calculada sobre o valor bruto do bem, uma vez ajustado pelo PAAG. As depreciações contábeis dos imóveis deverão calcular-se excluindo o valor do terreno. 
6) O valor que se tome para determinar o ganho ou perda no momento da venda dos bens depreciáveis, exauríveis ou amortizáveis será o custo ajustado pelo PAAG menos o valor da depreciação, exaustão ou amortizações acumuladas contábeis.

7) Se as valorizações técnicas efetuadas aos ativos ou o valor intrínseco ou o valor em bolsa superam o custo líquido do bem ajustado pelo PAAG, a diferença deverá levar-se como "Superávit por Valorización”. Tal diferença não será tomada como uma receita, nem fará parte do custo para determinar o ganho na venda do bem, nem também estará presente em seu valor para o cálculo da depreciação.

8) O valor dos ativos não monetários, uma vez ajustados pelo PAAG, deverá reduzir-se mediante uma provisão tecnicamente constituída quando exceda seu valor líquido de realização ou de mercado, segundo o caso. O valor das ações e os aportes em sociedades deverão reduzir-se a seu valor intrínseco ou em bolsa. O valor intrínseco resulta de dividir o Patrimônio Líquido da sociedade pelo número de ações em circulação.

\section{- Outros ajustes por Inflação}

No caso dos passivos, o tipo de ajuste que se aplica sobre eles é produto do UPAC, pela diferença em câmbio (quando se têm divisas em moeda estrangeira) ou por pacto de reajuste; portanto, o ajuste vai para uma conta de despesa ou receita financeira, segundo seja o caso. 
No ajuste dos valores do Patrimônio aparece a conta de Revalorização do Patrimônio, sobre a qual se registram todos ajustes às contas do patrimônio e a contrapartida é um débito na conta de correção monetária”.

\section{4.- PERU}

No Peru, os ajustes por inflação estão normatizados no aspecto fiscal e tributário pelo Decreto Legislativo $n^{0}$ 797, e regulamentado pelo Decreto Supremo ํㅜ 009-96-EF.

Os ajustes por inflação no aspecto contábil estão normatizados pelas Resoluções do Conselho Normativo de Contabilidade № 2, 3 e Resoluções de Contadoria № 003, 004, 005 e 009.

\section{a.- Fisco}

Segundo o artigo $1^{0}$ do D. Legislativo $797,{ }^{84}$ "os contribuintes geradores de renda de terceira categoria deverão aplicar as normas de Ajuste por Inflação do Balanço Geral, através delas se determinará a base imponível deste imposto, de acordo com o seguinte:

a) O ajuste por inflação é a atualização de todas os itens não monetários do balanço geral, em moeda com poder aquisitivo da data de fechamento do exercício. O Resultado por Exposição à Inflação (REI) resulta do maior valor nominal atribuído ao ativo não monetário, subtraindo os maiores valores nominais atribuídos ao passivo não monetário e ao Patrimônio líquido.

\footnotetext{
${ }^{84}$ IVERA Asociados. Op. citada. Lima, 1999. p. 375 - 390.
} 
b) Ao valor dos itens não monetários do balanço geral a atualizar-se deverá excluir-se as diferenças de câmbio e as reavaliações compreendidas em dito valor.

c) O fator de atualização a utilizar será o Índice de Preços de Atacado em Nível Nacional (IPM) que publica o Instituto Nacional de Estatística e Informática (INEI). Este índice é o resultado de dividir o índice de correção da data de atualização entre o correspondente à data de origem ou, segundo o caso, o índice de atualização anterior.

d) O ajuste por inflação obtido da aplicação do fator de atualização, terá um limite nos seguintes casos:

- Nos estoques, o limite será o valor de reposição, de acordo com as normas que estabeleça o Regulamento.

- No caso dos investimentos em valores, permanentes ou temporais, com cotação na bolsa de valores, o limite será o valor de cotação na bolsa de valores no fechamento do exercício, ou a última cotação anterior a essa data. No caso dos investimentos permanentes efetuados em filiais ou subsidiárias assim como em afiliadas ou associadas, o limite será o valor de participação patrimonial na data de atualização, de acordo com as normas que estabeleça o Regulamento, sem considerar se estão ou não cotados na bolsa de valores. 
- No caso de investimentos em valores sem cotação na bolsa de valores, para os investimentos permanentes o limite será o valor de participação patrimonial na data de atualização, de acordo com as normas que estabeleça o Regulamento. Para os investimentos em valores temporais o limite será o valor de aquisição ou de entrada ao patrimônio.

- No caso de terrenos urbanos e rústicos, o limite será o valor da tabela oficial vigente na data do ajuste.

e) Os limites de atualização estabelecidos no item d) do presente artigo, não poderão em nenhum caso ser menores aos respectivos valores de aquisição ou de entrada ao patrimônio.

De acordo com o art. $3^{0}$ do D. Legislativo 797, encontram-se obrigadas a realizar o ajuste por inflação as empresas geradoras de rendas de terceira categoria, compreendidas no regime geral do Imposto de Renda. Estas empresas são as seguintes:

a) Pessoas jurídicas

b) Empresas unipessoais

c) Empresas que atribuem suas rendas às partes contratantes.

No caso de sociedades de fato, associações em participação, joint ventures, consórcios, comunidade de bens e demais contratos de colaboração empresarial, as rendas serão atribuídas às pessoas naturais ou jurídicas que integram essas empresas. 
Não estão obrigados:

a) As empresas não obrigadas a levar contabilidade completa

b) As associações legalmente autorizadas de beneficência, assistência social, educação, culturais, gremiais, de moradia e outros de fins semelhantes, que obtenham renda de terceira categoria e destinem essa renda a seus fins específicos no país.

c) Empresas autorizadas legalmente a levar sua contabilidade em moeda estrangeira estão excluídas da aplicação do ajuste por inflação, exceto quando renunciem a dita autorização.

\section{Datas compreendidas do ajuste por inflação do Balanço Geral com} incidência tributária.

Anual: Para a determinação do Imposto de Renda do Exercício.

Janeiro e Semestral: Mudança do coeficiente ou porcentagem para os pagamentos antecipados do Imposto de Renda.

No mês: Mudança do Regime Especial de Renda ao Regime Geral quando seja pessoa jurídica.

Segundo o artigo $6^{\circ}$ para a determinação da renda bruta, o custo computável dos bens dos contribuintes sujeitos ao ajuste será o determinado com as normas do D. Legislativo $\mathrm{n}^{0} 797$ e do seu Regulamento. 
Os pagamentos antecipados do Imposto de Renda devem ser ajustados em função da variação do IPM ocorrida entre o mês do pagamento e o mês de fechamento do balanço. A quota de regularização do imposto deverá ser ajustada segundo a variação do IPM desde o mês do balanço até o mês anterior à data de pagamento ou até o mês anterior à data de vencimento do prazo da lei, o que ocorra primeiro.

Quando são aplicadas as normas de ajuste por inflação às contas de capital e ações laborais, o total do ajuste deve ser distribuído entre ambas contas para que possam manter a mesma proporção que havia antes da atualização.

Os contribuintes que façam o ajuste por inflação do balanço geral para fins tributários devem registrar os lançamentos contábeis com o fim de mostrar os valores ajustados dos ativos, passivos e patrimônio líquido.

\section{Contabilização e Apresentação}

Os ajustes por inflação deverão contabilizar-se nos livros oficiais, devendo refletir-se no balanço geral e na demonstração de resultado do período correspondente.

O resultado de atualização de cada conta não monetária deve ser registrado em conta divisionária separada, para manter o controle contábil do custo histórico em moeda nominal e dos incrementos por atualização;

Quando, para fins tributários, o contribuinte deva apresentar demonstrações contábeis comparativas, os números correspondentes ao período anterior devem 
apresentar-se atualizados em moeda com poder aquisitivo da data do fechamento do último período.

\section{b.- Conselho Normativo de Contabilidade ${ }^{85}$}

Segundo a Resolução № 2 do Conselho Normativo de Contabilidade, são permitidos os ajustes por inflação nas quatro Demonstrações Financeiras básicas: Balanço Geral, Demonstração de Resultado, Demonstração das Mutações do Patrimônio Líquido e Demonstração dos Fluxos de Caixa.

“Metodologia do Ajuste integral das Demonstrações Financeiras por efeito da Inflação

\section{Normas Gerais dos Ajustes por Inflação}

De acordo com a Resolução $N^{0} 2$ do Conselho Normativo de Contabilidade, as normas gerais são:

a) Todas as contas das demonstrações financeiras devem ser classificados em monetárias e não monetárias.- As contas monetárias que estão expressas em moeda com poder aquisitivo da data de atualização não são atualizadas.

\section{b) Operações em Moeda Estrangeira}

1. Ativo e Passivo em moeda estrangeira.- As contas de ativo e passivo em moeda estrangeira, na data de fechamento do Balanço Geral estão expressas

\footnotetext{
${ }^{85}$ IVERA Asociados. Op. citada. Lima, 1999. p. 423 - 452.
} 
em moeda nacional no tipo de câmbio vigente nessa data. Por isso não serão objetos de ajuste adicionais.

2. Bens e Serviços que são pagos em Moeda Estrangeira.- Para atualizar os bens e serviços adquiridos em moeda estrangeira, tais como estoques, imóveis, maquinaria e equipamento, seguros, publicidade e outros; deverá se subtrair a diferença de câmbio incorporada ao custo e aplicar o fator de ajuste correspondente, de acordo à antiguidade da conta.

3. Receitas e Despesas.- A diferença de câmbio imputável ao resultado do exercício, proveniente do recebimento de direitos ou pagamento de obrigações, assim como as provenientes da compra e venda de divisas não são atualizadas.

\section{c) Contas a Receber e Contas a Pagar (moeda nacional) sujeitas a} cláusulas de reajuste.- Estas contas estão no balanço geral avaliadas de acordo a normas ou convênios estabelecidos. Por isso não serão objetos de reajuste adicionais.

d) Determina-se a antiguidade.- Data da origem das contas não monetárias. Esta data pode corresponder a:

- Data em que aconteceu a operação.

- O período razoável determinado dentro do qual encontra-se compreendida a data provável de origem.

- $\quad$ A data em que aconteceu a última atualização. 


\section{e) Aplica-se o fator de ajuste correspondente.}

Este fator de ajuste se obtém dividindo o índice de preços que correspondem à data de fechamento do período, objeto de atualização entre o índice de preços na data de origem dos itens por atualizar.

$$
\text { Fator de Ajuste }=\frac{\text { Fator de Índice de preco (atual) }}{\text { Ajuste Índice de Preços (origem) }}
$$

f) Determina-se o valor atualizado fazendo a seguinte operação: o valor em livros da conta não monetária vezes o fator de ajuste.

g) As contas não monetárias atualizadas não deverão exceder seu valor de mercado, de utilização econômica, participação patrimonial, ou valor nominal, segundo seja o caso.

h) Quando um procedimento de atualização não seja aplicado uniformemente de período a período, deve justificar-se as razões da mudança e estimar-se os efeitos dela. Para fins tributários, deve ser explicitado na declaração jurada do Imposto de Renda.

i) A atualização deve realizar-se a partir dos saldos ajustados do período anterior, considerando o item g).

j) Montante do ajuste.- O montante do ajuste será:

1. No caso de atualização prévia, a diferença entre o valor atualizado e o valor em livros. 
2. No caso da atualização correspondente ao período, deverá ser considerado o seguinte:

- Quando as contas sejam atualizadas previamente, o montante do ajuste será a diferença entre o novo valor atualizado e o valor atualizado anterior.

- Quando as contas sejam incorporadas no exercício, o montante do ajuste será a diferença entre o valor atualizado e o valor em livros.

k) Resultado por exposição da Inflação.-A atualização das contas não monetárias do balanço geral correspondente à atualização previa terá como contrapartida à conta especial denominada "Resultado por Exposição à Inflação (REI)", que por sua natureza afetará os resultados acumulados no início do período objeto do ajuste.

O ajuste das contas não monetárias do Balanço Geral, assim como das contas da Demonstração do Resultado no final do primeiro período de ajuste e dos períodos seguintes, terá como contrapartida a conta "Resultado por Exposição à Inflação" que afetará ao resultado do exercício.

I) Contabilização.- Os ajustes por inflação regulamentados pela presente norma devem ser contabilizados nos livros oficiais, devendo refletir-se nas demonstrações financeiras da empresa.

O resultado da atualização de cada conta não monetária deve ser controlado em conta separada, para manter o controle contábil do custo histórico 
em moeda nominal e do incremento por atualização, não obstante a atualização das contas da demonstração de resultados pode registrar-se diretamente nas contas, já que seus efeitos estarão refletidos na conta do REI referida no item anterior.

II) Demonstrações financeiras comparativas.- Para a apresentação comparativa das demonstrações financeiras atualizadas, todos os itens deverão se expressar em unidade de mensuração homogênea, ou moeda de um mesmo poder aquisitivo; que será aquela do fechamento do último exercício que se apresenta comparativamente. Para este fim, se atualizarão os itens monetários e não monetários das demonstrações financeiras do exercício precedente utilizando o fator de ajuste da inflação encontrada no período".

Existem tratamentos específicos para os seguintes itens: Estoques, Valores, Contas a Receber, Despesas pagas por antecipado, Investimentos Permanentes, Imobilizado, Intangíveis, Contas a Pagar, Patrimônio Líquido, Custos de Venda, Contas de Resultado".

\subsubsection{5.- VENEZUELA ${ }^{86}$}

"A Declaração de Princípios de contabilidade, DPC-10 emitida em 23 de agosto de 1991 estabelece as normas relacionadas com a correção monetária das Demonstrações Financeiras.

\footnotetext{
${ }^{86}$ Carpio, Fernando Catacora. Op. citada. Caracas, 1999 e http://www.fccpv.org/
} 
A inflação pode-se definir como o incremento percentual dos preços de uma cesta de bens e serviços representativa de uma economia, entre dois períodos determinados. É um fenômeno econômico que gera diversas conseqüências, uma das mais negativas é a perda do poder aquisitivo da moeda ou do signo monetário representativo da economia.

A inflação tem afetado a Venezuela durante mais de trinta anos, período no qual tem superado os três dígitos.

A inflação na Venezuela é calculada por meio de diferentes índices de preços, dentro deles estão os seguintes:

- Índice geral de preços no nível de consumidor

- Índice de preços de atacado

- Índice geral de preços no nível de produtor

Estes três tipos de índices são calculados em forma mensal pelo Banco Central de Venezuela. O índice geral de preços no nível de consumidor mensura o crescimento que os preços têm no nível da última etapa do processo de comercialização, ou seja, o consumidor. Este índice é composto pelos seguintes itens:

- alimentos, bebidas e tabaco;

- vestido e calçado;

- despesas da casa;

- despesas diversas. 
O segundo tipo, o índice de preços de atacado, mensura o efeito da inflação no nível dos agentes intermediários que realizam operações na economia, e classifica-se nos seguintes tipos:

- nacional;

- importado;

- insumos da construção.

O terceiro tipo, o índice geral de preços no nível de produtor, mensura o efeito da inflação no momento no qual produzem ou geram-se os bens ou serviços na economia e, no caso de Venezuela, classificam-se em:

- Indústria fabril privada;

- Insumos da construção;"

$\mathrm{Na}$ opinião de Carpio, ${ }^{87}$ "a ordem correta na aplicação de índices para mensurar a inflação nas demonstrações financeiras das empresas é a seguinte:

- Defletor do produto interno bruto;

- Índice nacional de preços no nível de consumidor;

- Índice de preços de atacado.

O problema apresenta-se quando um índice é local e é aplicado para mensurar operações que não necessariamente ocorrem no âmbito local. No caso do IPC utilizado para efeitos da DPC-10, este é um número que mensura mensalmente o crescimento dos preços na área metropolitana de Caracas".

\footnotetext{
${ }^{87}$ Carpio, Fernando Catacora. Op. citada. Caracas, 1999.
} 
A DPC-10 estabelece no parágrafo 9 o seguinte:

88“Tradicionalmente sugerem-se três métodos de ajuste para mensurar os efeitos da inflação:

a) O Método do Nível Geral de Preços. É a aplicação integral ou parcial de um índice que permite a estimação de preços constantes na economia.

b) O Método dos Custos Correntes. É a reavaliação de ativos mediante índices específicos de preços ou outros critérios.

c) O Método Misto. É uma mistura dos dois métodos anteriores. Consiste em aplicar o primeiro e depois o segundo.

O Método do Nível Geral de Preços (NGP) ajusta integralmente as demonstrações financeiras, utilizando o IPC da área metropolitana de Caracas.

O Método de Custos Correntes substitui de maneira parcial os valores de certos ativos, mas não é aplicado a todos os itens das demonstrações financeiras pelo que é qualificado de parcial.

O Método Misto é mais completo que os dois anteriores, porque os combina. Ajusta as demonstrações financeiras pelo método do nível geral de preços, depois se atualizam os ativos não monetários, incorporando seus valores correntes, e modificando o custo de vendas e as despesas de depreciação do exercício de acordo com estes valores. Esta incorporação origina uma variação no

\footnotetext{
${ }^{88}$ DPC-10 citada por Carpio, Fernando. Op. citada. Caracas, 1999.
} 
patrimônio denominada resultado não realizado por posse de ativos não monetários.

O resultado não realizado por posse de ativos não monetários é o excesso ou defeito dos valores correntes dos ativos não monetários sobre o valor histórico ajustado segundo o nível geral de preços. O resultado realizado em um período econômico pela posse de ativos não monetários é a diferença entre o custo de vendas e as despesas de depreciação com base nos valores correntes e os valores obtidos por estes mesmos conceitos, segundo o método do nível geral de preços. Devido a que o custo de vendas e a depreciação receberam um ajuste igual à diferença antes citada, o resultado no período é igual ao obtido através do método do nível geral de preços. Quando se procede desta maneira, compreendese melhor o resultado geral pelas operações e o resultado que se deriva pela simples posse dos bens. Fala-se assim da manutenção do capital financeiro.

Devido à inflação, os itens das demonstrações financeiras classificam-se em dois tipos:

Itens de natureza monetária: que devido a uma grande taxa de inflação perdem seu valor.

Itens de natureza não monetária: que aumentam seu valor em épocas de inflação constante.

Para a aplicação desta norma houve um período de transição de $01^{0} \mathrm{de}$ janeiro de 1993 até o 30 de novembro de 1997. 
O parágrafo 23 fala sobre a apresentação de demonstrações financeiras atualizadas segundo valores determinados com base em o Método NGP ou o Método Misto. A apresentação deve-se fazer em um só relatório no corpo das demonstrações financeiras históricas ou em demonstrações financeiras separadas.

Os valores referidos anteriormente são os compreendidos no Balanço Geral, na Demonstração de Resultado, na Demonstração de Mudanças no Patrimônio Líquido e outros que não sejam a Demonstração de Origem e Aplicação de Recursos e a Demonstração de Fluxos de Caixa.

No terceiro boletim atualizado da DPC-10 estabelece-se o seguinte:

De acordo com normas internacionais, as demonstrações financeiras atualizadas integralmente devem apresentar-se no corpo das demonstrações financeiras históricas em outra coluna ou completos depois dos históricos, em um só relatório e com relatório de auditoria.

No terceiro boletim da DPC-10 de 1994 foram incluídas a Demonstração de Origem e Aplicação de Recursos e a Demonstração de Fluxos de Caixa.

Os parágrafos 34 e 37 determinam o seguinte:

As demonstrações financeiras devem informar o método elegido para sua atualização. Deverá informar-se também o índice de preços no início e no fim de cada período econômico.

Quando seja empregado o Método Misto, deverá informar-se: 
a) O índice relevante utilizado.

b) Se não foi utilizado um índice relevante deverá informar-se o procedimento seguido.

c) Outras informações.

Quando existir um superávit por posse, deve-se informar com quais ativos não monetários está relacionado.

Quando não se tenha informação de investimentos em outras empresas para ajustar adequadamente, deve-se informar a metodologia empregada.

Deve diferenciar-se no capital contábil ou patrimônio o seguinte:

a) O capital social nominal

b) A atualização do capital social

c) Os resultados obtidos atualizados

d) As reservas atualizadas

e) O resultado acumulado por exposição à inflação, menos qualquer parte dele realizado e incluído no c); recomenda-se, por um período de tempo de prudência manter, os resultados monetários separados dos resultados obtidos no patrimônio para observar seu comportamento.

E quando foi utilizado o Método Misto:

f) O superávit por posse de ativos não monetários.

Na Metodologia deve considerar-se o seguinte: 
Os itens monetários na data de encerramento se apresentam em seus valores nominais. Os itens monetários de datas anteriores se apresentam com seus valores respectivos mais ajustados, ou seja, dividindo esses valores entre o índice de preços da data respectiva vezes o índice de encerramento.

Portanto as demonstrações financeiras básicas devem apresentar-se em moeda de uma data.

A DPC-10- em seus parágrafos 39 e 40 estabelecem o seguinte em relação aos estoques:

39. No método do nível geral de preços, determina-se a data de origem por categorias, agrupando os itens por mês, período de ano, ou ano de origem, o mais apropriado.

40. O valor atualizado por índice de preços está sujeito à norma do menor entre o custo ajustado e o valor recuperável.

A DPC-10 estabelece tratamentos especiais para os itens:

\section{Estoques}

Custo de Vendas

Ativo Fixo

Depreciação

Débitos e créditos diferidos

Investimentos

Capital Social 
Receitas retidas.

Resultado por exposição à inflação.

No primeiro boletim de Atualização do DPC-10 determina-se:

A reavaliação e suas atualizações sempre que seja feito de acordo com o Método Misto é um princípio aceito na Venezuela.

NGP + Reavaliação = Método Misto.

A entrada em vigência deste informe considerava que aquelas entidades que apresentem as demonstrações financeiras atualizadas como únicas estarão cumprindo com os Princípios.

A Reavaliação dos itens não monetários dentro do Método Misto pode-se fazer dentro de uma das seguintes alternativas:

a) Todo o Ativo Fixo

b) Todo o Ativo Fixo e os estoques

Deve-se informar a opção eleita. A avaliação não deve se fazer em forma global. Todos os bens de classe e características comuns devem tratar-se em forma similar, no sentido de não incluir ou excluir determinados ativos com o objetivo de conseguir resultados predeterminados.

No segundo boletim de atualização da DPC 10, estabelece-se o seguinte: 
Para efeitos das demonstrações financeiras atualizadas deve-se eliminar, antes da atualização das cifras históricas, qualquer montante previamente reconhecido como parte do custo dos ativos provenientes de desvalorizações ou flutuações no valor da moeda, incluindo qualquer montante registrado em débitos diferidos por esse motivo. Este informe exige a saída de valores capitalizados como diferenças cambiais.

No caso de ativos alienados ou retirados objeto da avaliação:

O lucro ou a perda proveniente da alienação ou retiro de um ativo fixo reavaliado é determinado de acordo com o valor líquido atualizado e não do custo histórico.

Isto é aplicado no método NGP ou no método Misto.

No caso do Resultado por posse:

Os resultados por posse conhecidos como superávit por reavaliação devem determinar-se de acordo com o parágrafo 18 da DPC-10.

Nas demonstrações financeiras consolidadas ou combinadas, onde a companhia matriz e suas filiais reavaliaram seus ativos fixos, os resultados por posse consolidados apresentam-se dessa forma.

Para consolidar ou combinar demonstrações financeiras todas as empresas devem utilizar o mesmo método (NGP ou Misto).

Custo Integral de financiamento 
$\mathrm{Na}$ Demonstração de Resultados atualizada, os itens que correspondam a juros não capitalizáveis (líquido), lucros ou perdas por flutuações cambiais, e o resultado monetário líquido serão apresentados como Custo Integral de financiamento.

No terceiro boletim da DPC-10 estabelece-se o seguinte:

A DPC-10 e seus boletins são aplicáveis às demonstrações financeiras básicas:

\section{Balanço Geral}

Demonstração de Resultados

Demonstração das Mudanças no Patrimônio Líquido

Demonstração de Fluxos de Caixa

Os saldos dos itens em moeda estrangeiros se ajustam com a taxa de câmbio na data do balanço geral correspondente. No processo de atualização para efeitos comparativos, os saldos em moeda estrangeira nos Balanços gerais de fechamentos anteriores, os quais já devem estar ajustados às taxas de câmbio na data de seu fechamento respectivo, ajustam-se com a variação no IPC desde a data desse balanço anterior até a data do fechamento atual.

No parágrafo 16 diz o seguinte:

O montante atualizado de um item não monetário é reduzido quando excede o montante recuperável de uso futuro (incluindo a venda ou outra disposição). Nestes casos são reduzidos os montantes atualizados de 
Propriedades, Plantas e Equipamentos, Crédito mercantil (ágio), patentes e marcas a seu valor de recuperação líquido e os investimentos de curto prazo a seu valor de mercado.

Os parágrafos 26 e 27 estabelecem o seguinte:

26. No método NGP não se podem fazer ajustes às cifras já atualizadas. A atualização é uma correção monetária das cifras históricas e qualquer ajuste deve se fazer nestas cifras.

27. No método NGP não pode haver discrepâncias entre as cifras ajustadas pelos conceitos indicados na DPC-10 e seus boletins de atualização (avaliações, diferenças em câmbio capitalizadas, juros de financiamento, etc.), sua data da operação, o fator de atualização correspondente a essa data e as cifras atualizadas.

Não é considerado um procedimento adequado fazer lançamentos com cifras globais entre itens atualizados.

Há duas maneiras de registrar contabilmente o efeito da inflação nos livros contábeis, entendidos como livros legais no Código de Comércio.

- Afetar contas reais

- Afetar contas reais e nominais

Qualquer erro de apreciação ou de critério na atualização será refletido na conta de resultado por re-exposição à inflação acumulada. Em um nível mais detalhado não é correto realizar: 
- Ajustes globais

- Ajustes em contas de ordem

- Ajustes em contas parciais.

O parágrafo 31 diz o seguinte:

31. As despesas de depreciação do exercício são atualizadas no método NGP colocando as alíquotas históricas registradas nos livros legais, ajustadas pelos conceitos estabelecidos na DPC-10 (avaliações, diferenças em câmbio capitalizadas, juros de financiamento, etc.) a data de aquisição ou construção do ativo que os gera. Não deve haver discrepância entre a alíquota da depreciação histórica, seu fator de atualização e a cifra atualizada. Não é adequado efetuar atualizações por distribuição proporcional em base à atualização global dos ativos fixos ou sua depreciação acumulada nem qualquer outro médio global que possa introduzir fatores de distorção nos resultados, de difícil verificação.

Como conseqüência deste parágrafo, deve-se eliminar qualquer efeito por:

- Avaliações

- Diferenças em câmbio capitalizadas

- Juros, despesas.

E depois atualizar a despesa por depreciação correspondente considerando a data de aquisição ou construção do ativo com o qual está relacionado.

No parágrafo 45 define que os ativos fixos em cifras históricas somente podem apresentar reavaliações até 8 de novembro de 1992. 
Depois dessa data, o ativo fixo somente pode ser reavaliado no método integral Misto. O Método Misto, no caso dos ativos fixos, consiste em unir o Método do Nível Geral de Preços mais as Reavaliações.

Na data já não devem existir apresentações complementares; somente são permitidas as cifras atualizadas de acordo com os métodos NGP ou Misto, segundo os Princípios de Contabilidade Geralmente Aceitos na Venezuela". 


\section{REFERÊNCI AS BI BLI OGRÁFICAS}

CARPIO, Fernando Catacora. PCGA en Venezuela, Comentarios y Analisis de todas las Declaraciones e Principios de Contabilidad vigentes en Venezuela. Caracas, 1999.

C.F.C. Conselho Federal de Contabilidade. Princípios Fundamentais de Contabilidade e normas brasileiras de contabilidade. São Paulo: Atlas, 1995.

CONASEV. Reglamento para la preparación de información financeira e información auditada. 1.ed. Lima: Conasev, 1998.

C.R.C. Conselho Regional de Contabilidade do Estado de São Paulo. Contabilidade no Contexto International. 1.ed. Vol 9. São Paulo: Editora Atlas S.A., 1997. 159 p.

DA ROSA, Paulo Moreira. A Contabilidade no Mercosul. 1.ed. São Paulo: Editora Atlas S.A., 1999, 152p.

F.C.C.P.V. Federación de Colegios de Contadores Públicos de Venezuela. Los Principios de Contabilidad y las Normas y Procedimientos de Auditoría de Aceptación General en Venezuela y Otras Publicaciones Técnicas de la Federación de Colegios de Contadores Públicos de Venezuela. 1.ed. Caracas: Fondo Editorial del Contador Público Venezolano, 1996. 177p.

FINANCIAL ACCOUNTING STANDARDS BOARD - FASB. Current text Accounting standards. V.I e II. John Wiley \& Sons, New York, Edição 1997/98. FIPECAFI, IUDÍCIBUS, Sérgio de, MARTINS, Eliseu, GELBCKE, Ernesto Rubens. Manual de contabilidade das sociedades por ações. 5ed. São Paulo: Ed. Atlas, 2000, 508p. 
GONZÁLEZ, Patrícia González. Revisão crítica do Sistema de correção monetária Vigente na Colômbia, sob uma perspectiva de técnica desenvolvida no Brasil.

São Paulo, 1999. Tese (Mestrado) - Faculdade de Economia, Administração e Contabilidade da Universidade de São Paulo.

IASC. International Accounting Standards Committee. International Accounting Standards - IAS. London, 2000.

IBRACON. Princípios contábeis. 2 ed. São Paulo: Ed. Atlas, 1994. NPC 7 Ativo Imobilizado. São Paulo, 2001. 18p.

IFAC e IBRACON. Normas Internacionais de Auditoria. Brasil, 1998. p. 372-417. INFORMATIVO CABALLERO BUSTAMANTE. Lima, Perú. N. 421, abril 1999. 10p. Manual de Consultoria Contable. 1 ed. Lima, Perú. 1999, 98p. Informes Contables. 1.ed. Lima, Perú. 1999, 98p.

IOB, Temática Contábil e Balanços. Arrendamento mercantil (leasing). (1 parte) São Paulo, outubro 1998, 8p.

Arrendamento mercantil (leasing). (2 parte). São Paulo, outubro 1998, 7p.

Arrendamento mercantil (leasing ) (3 parte). São Paulo, outubro 1998, 5p.

Aspectos Financeiros do Arrendamento Mercantil. São Paulo.

n. 23, Junho 1999. 5p.

Arrendamento mercantil (leasing ) (1 e 2 parte). São Paulo. N. 46 e 47, novembro 2000, $15 p$.

Quais Investimentos devem ser avaliados pela Equivalência Patrimonial? (1 e 2 parte). São Paulo. n. 40 e 41, outubro 1999, 16p. 
Quais Investimentos devem ser avaliados pela Equivalência Patrimonial? (1 parte). São Paulo. n. 45, novembro 2001, 7p.

Normas e Procedimentos de Contabilidade do IBRACON - NPC 02Estoques - Texto Revisado e Atualizado em 1999. São Paulo, n. 1, janeiro de $2000,5 p$.

Imposto de Renda e Legislação Societária. Investimentos avaliados pela Equivalência Patrimonial - Resultado de Avaliação - Lucros e Dividendos recebidos. São Paulo. N. 23, junho 1999, 6p.

IUDíCIBUS, Sérgio de. Teoria da Contabilidade. 5.ed. São Paulo: Editora Atlas S.A., 1997. 330p.

IVERA ASOCIADOS, C.P.C. ATAUPILLCO, Dante Vera. Impuesto a la Renta, Ajustes por Inflación, Flujos de Efectivo. 1.ed. Lima: Editorial Ivera, 1997.

LEI Nㅜㄴ 6.404 de 15 de dezembro de 1976 alterada pela Lei $n^{0} 9.457$ de 5 de maio de 1997.

LISBOA, Nahor Plácido. Harmonização de Normas e Práticas Contábeis no Mercosul. São Paulo, 2000. 122p. Tese (Doutorado) - Faculdade de Economia, Administração e Contabilidade da Universidade de São Paulo.

MARTINS, Eliseu. Análise da Correção Monetária das Demonstrações Financeiras e.ed. São Paulo: Atlas S.A., 1993, 157p.

MATARAZZO, Dante C. Análise Financeira de Balanços. 4.ed. São Paulo: Atlas S.A., 1997, 463p.

Régimen Contable Colombiano, Santa Fé de Bogotá: Legis Editores S.A., 1996.

RUEDA, Gregorio Reyes. Plan Contable General Revisado. Estructurado y Comentado. 1.ed. Lima: Edigraber, 1999. 
YAMAMOTO, Marina Mitiyo. A contabilidade e o Mercosul. São Paulo, 1996. 219p Tese (Doutorado) - Faculdade de Economia, Administração e Contabilidade da Universidade de São Paulo.

Páginas da Internet:

http://www.ccpl.org.pe/

http://www.cfc.org.br/

http://www.cienciaseconomicas.com/fagce.htm/

http://www.comunidadeandina.org

http://www.facpce.com.ar/

http://www.fccpv.org/

http://www.financewise.com

http://www.ibracon.com.br

http://www.incp.org.co

http://www.jccconta.gov.co/

http://www.mercosul.org

http://www.mercosur.com 


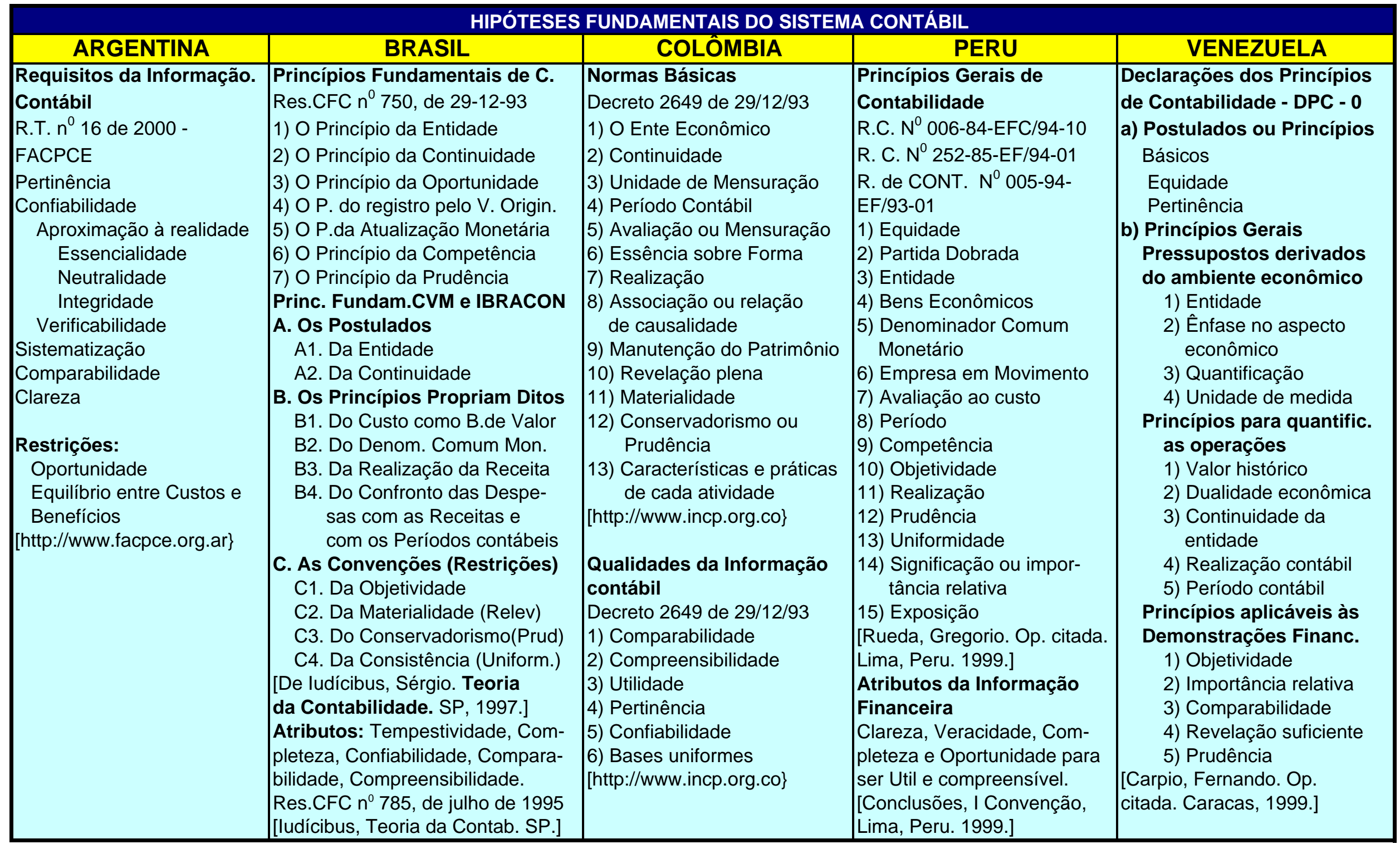


ESTOQUES

Normas Contábeis

Mercadorias, Produtos Acabados, Produtos em elaboração, Matérias primas, almoxarifado, etc.

\begin{tabular}{|l|l|l|l|l|}
\hline \multicolumn{1}{|c|}{ ARGENTINA } & \multicolumn{1}{|c|}{ BRASIL } & \multicolumn{1}{c|}{ COLÔMBIA } & \multicolumn{1}{c|}{ PERU } & \multicolumn{1}{c|}{ VENEZUELA } \\
\hline $\begin{array}{l}\text { Custo de Reposição } \\
\text { Custo Histórico }\end{array}$ & $\begin{array}{l}\text { Custo Histórico ou } \\
\text { Valor de Mercado, o } \\
\text { menor } \\
\text { Ibracon: Custo ou Valor } \\
\text { Líquido de Realização, } \\
\text { (VLR), o menor }\end{array}$ & $\begin{array}{l}\text { Custo Histórico ou } \\
\text { Valor Líquido Realizável, } \\
\text { o menor }\end{array}$ & $\begin{array}{l}\text { Custo Histórico } \\
\text { Custo Corrigido ou } \\
\text { Valor do Mercado (VLR) } \\
\text { o menor }\end{array}$ & $\begin{array}{l}\text { Custo Histórico } \\
\text { Custo Corrigido ou } \\
\text { Valor recuperável, o } \\
\text { menor } \\
\text { - VLR } \\
\text { - Valor de uso }\end{array}$ \\
\hline
\end{tabular}

\section{Fisco}

Mercadorias, Produtos Acabados, Produtos em elaboração, Matérias primas, almoxarifado, etc.

\begin{tabular}{|c|c|c|c|c|}
\hline ARGENTINA & BRASIL & COLÔMBIA & PERU & VENEZUELA \\
\hline $\begin{array}{l}\text { Custo de Aquisição } \\
\text { Método: } \\
\text { UEPS ou LIFO }\end{array}$ & $\begin{array}{l}\text { Custo de Aquisição } \\
\text { Métodos: } \\
\text { Custo Médio } \\
\text { PEPS ou FIFO }\end{array}$ & $\begin{array}{l}\text { Custo Histórico } \\
\text { Valor Líq. de Realização, } \\
\text { o menor } \\
\text { Métodos: Custo médio } \\
\text { ponderado } \\
\text { PEPS } \\
\text { UEPS } \\
\text { de Identificação } \\
\text { Específica } \\
\text { Outros }\end{array}$ & $\begin{array}{l}\text { Custo Histórico } \\
\text { Custo Corrigido ou } \\
\text { Custo de Reposição, o } \\
\text { menor } \\
\text { Método: } \\
\quad \text { Custo médio } \\
\text { PEPS ou FIFO }\end{array}$ & \begin{tabular}{|l} 
Custo Histórico \\
Custo Corrigido ou \\
Valor recuperável, o \\
menor \\
Mét.: Custo médio \\
PEPS ou FIFO \\
UEPS ou LIFO \\
Identificação \\
específica
\end{tabular} \\
\hline
\end{tabular}




\begin{tabular}{|l|l|l|l|l|}
\hline \multicolumn{4}{|c|}{ Bens Fungíveis } \\
\hline \multicolumn{1}{|c|}{ ARGENTINA } & \multicolumn{1}{|c|}{ BRASIL } & \multicolumn{1}{c|}{ COLÔMBIA } & \multicolumn{1}{c|}{ PERU } & \multicolumn{1}{c|}{ VENEZUELA } \\
\hline $\begin{array}{l}\text { Valor Líquido de } \\
\text { Realização }\end{array}$ & Valor de Mercado & $\begin{array}{l}\text { Critério não previsto } \\
\text { nas normas }\end{array}$ & $\begin{array}{l}\text { Critério não previsto } \\
\text { nas normas }\end{array}$ & $\begin{array}{l}\text { Critério não previsto } \\
\text { nas normas }\end{array}$ \\
\hline
\end{tabular}

\begin{tabular}{|c|c|c|c|c|}
\hline \multicolumn{5}{|c|}{ Produtos agrícolas, animais e Extrativos } \\
\hline ARGENTINA & BRASIL & COLÔMBIA & PERU & VENEZUELA \\
\hline $\begin{array}{l}\text { Valor Líquido de } \\
\text { Realização }\end{array}$ & $\begin{array}{l}\text { Valor de Mercado } \\
\text { a) atividade seja } \\
\text { primária } \\
\text { b) Que o custo de } \\
\text { produção seja de } \\
\text { seja de difícil } \\
\text { determinação } \\
\text { c) Efetivo mercado } \\
\text { que possibilite } \\
\text { a liquidez imediata }\end{array}$ & $\begin{array}{l}\text { Nas plantações agrícolas } \\
\text { utiliza-se E. Permanente } \\
\text { Amortização depende de } \\
\text { seu ciclo agronômico }\end{array}$ & $\begin{array}{l}\text { Critério não previsto } \\
\text { nas normas }\end{array}$ & $\begin{array}{l}\text { Critério não previsto } \\
\text { nas normas }\end{array}$ \\
\hline
\end{tabular}

\begin{tabular}{|l|l|l|l|l|}
\hline \multicolumn{5}{|c|}{ Estoques em Produço ou Construção que se prolongue no tempo } \\
\hline \multicolumn{1}{|c|}{ ARGENTINA } & \multicolumn{1}{|c|}{ BRASIL } & \multicolumn{1}{c|}{ COLÔMBIA } & \multicolumn{1}{c|}{ PERU } & \multicolumn{1}{c|}{ VENEZUELA } \\
\hline $\begin{array}{l}\text { Valor Líquido de } \\
\text { Realização }\end{array}$ & $\begin{array}{l}\text { Custo Histórico ou } \\
\text { V. de Mercado, o menor }\end{array}$ & $\begin{array}{l}\text { Critério não previsto } \\
\text { nas normas }\end{array}$ & $\begin{array}{l}\text { Critério não previsto } \\
\text { nas normas }\end{array}$ & $\begin{array}{l}\text { Critério não previsto } \\
\text { nas normas }\end{array}$ \\
\hline
\end{tabular}

\begin{tabular}{|l|l|l|l|l|}
\hline \multicolumn{1}{|c|}{ ARGENTINA } & \multicolumn{1}{|c|}{ BRASIL } & \multicolumn{1}{c|}{ COLÔMBIA } & \multicolumn{1}{c|}{ PERU } & VENEZUELA \\
\hline $\begin{array}{l}\text { Critério não previsto } \\
\text { nas normas }\end{array}$ & $\begin{array}{l}\text { Valor Líquido de } \\
\text { Realização }\end{array}$ & $\begin{array}{l}\text { Critério não previsto } \\
\text { nas normas }\end{array}$ & $\begin{array}{l}\text { Critério não previsto } \\
\text { nas normas }\end{array}$ & $\begin{array}{l}\text { Critério não previsto } \\
\text { nas normas }\end{array}$ \\
\hline
\end{tabular}

